PROTEST AND SOCIAL MOVEMENTS

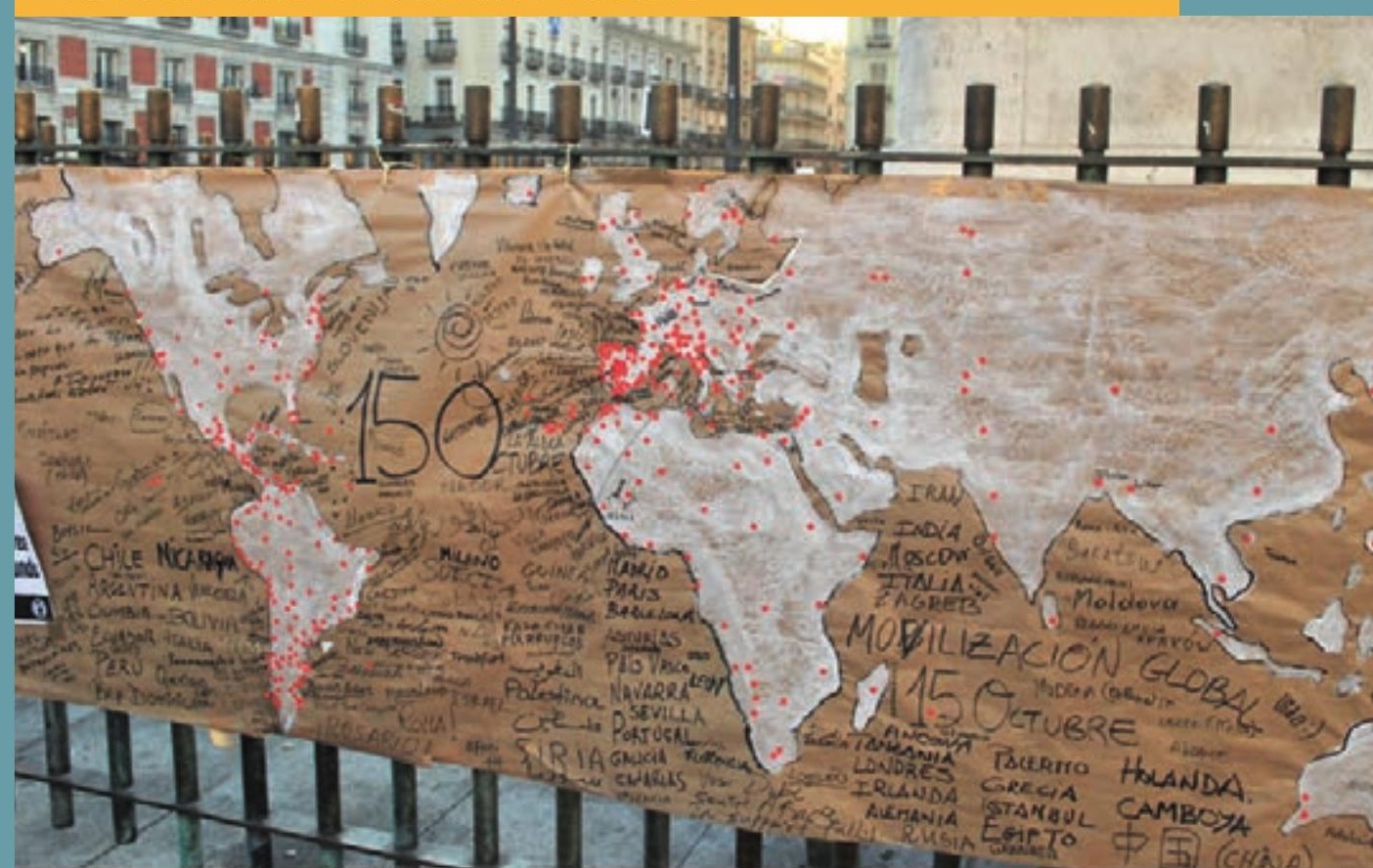

Edited by Marcos Ancelovici, Pascale Dufour and Héloïse Nez

\title{
Street Politics in the \\ Age of Austerity
}

\section{From the Indignados to Occupy}


Street Politics in the Age of Austerity 


\section{Protest and Social Movements}

Recent years have seen an explosion of protest movements around the world, and academic theories are racing to catch up with them. This series aims to further our understanding of the origins, dealings, decisions, and outcomes of social movements by fostering dialogue among many traditions of thought, across European nations and across continents. All theoretical perspectives are welcome. Books in the series typically combine theory with empirical research, dealing with various types of mobilization, from neighborhood groups to revolutions. We especially welcome work that synthesizes or compares different approaches to social movements, such as cultural and structural traditions, micro- and macro-social, economic and ideal, or qualitative and quantitative. Books in the series will be published in English. One goal is to encourage nonnative speakers to introduce their work to Anglophone audiences. Another is to maximize accessibility: all books will be available in open access within a year after printed publication.

\section{Series Editors}

Jan Willem Duyvendak is professor of Sociology at the University of Amsterdam. James M. Jasper teaches at the Graduate Center of the City University of New York. 


\title{
Street Politics in the Age of Austerity
}

From the Indignados to Occupy

\author{
Edited by \\ Marcos Ancelovici, Pascale Dufour and Héloïse Nez
}


Cover illustration: Map of world protests posted at the Puerta del Sol, in Madrid, during the 15 October 2011 global day of protest. Picture by Héloïse Nez.

Cover design: Coördesign, Leiden

Typesetting: Crius Group, Hulshout

Amsterdam University Press English-language titles are distributed in the US and Canada by the University of Chicago Press.

$\begin{array}{ll}\text { ISBN } & 978 \text { 90 } 89647634 \\ \text { e-ISBN } & 97890485^{2} 5461 \text { (pdf) } \\ \text { DOI } & 10.5117 / 9789089647634 \\ \text { NUR } & 740\end{array}$

(c) Marcos Ancelovici, Pascale Dufour and Héloïse Nez / Amsterdam University Press B.V., Amsterdam 2016

All rights reserved. Without limiting the rights under copyright reserved above, no part of this book may be reproduced, stored in or introduced into a retrieval system, or transmitted, in any form or by any means (electronic, mechanical, photocopying, recording or otherwise) without the written permission of both the copyright owner and the author of the book.

Every effort has been made to obtain permission to use all copyrighted illustrations reproduced in this book. Nonetheless, whosoever believes to have rights to this material is advised to contact the publisher. 


\section{Contents}

Acknowledgements

1 Introduction

From the Indignados to Occupy: Prospects for Comparison

Pascale Dufour, Héloïse Nez and Marcos Ancelovici

\section{Part 1 How Structural Factors Shape Mobilization}

2 Austerity and New Spaces for Protest

The Financial Crisis and Its Victims

George Ross

3 Mobilization of Protest in the Age of Austerity Hanspeter Kriesi

4 The Spanish Indignados and Israel's Social Justice Movement

The Role of Political Cleavages in Two Large-Scale Protests

Ignacia Perugorría, Michael Shalev and Benjamín Tejerina

\section{Part 2 The Practical and Spatial Dimensions of Activism}

5 "We Must Register a Victory to Continue Fighting"

Locating the Action of the Indignados in Madrid

Héloüse Nez

6 The Spatial Dimensions of the Greek Protest Campaign against the Troika's Memoranda and Austerity, 2010-2013

Maria Kousis

7 Occupy Montreal and the Politics of Horizontalism 


\section{Part 3 Complex Diffusion, from the Global Justice Movement to Indignados to Occupy}

8 Social Movements and Political Moments

Reflections on the Intersections of Global Justice Movements \& Occupy Wall Street

Jackie Smith

9 A Global Movement for Real Democracy?

The Resonance of Anti-Austerity Protest from Spain and Greece to Occupy Wall Street

Leonidas Oikonomakis and Jérôme E. Roos

\section{Part 4 When the Crisis Is not Enough}

10 Camps as the Sole Symbolic Expression of Protest

The Difficulties of Occupy in Ireland

Clément Desbos and Frédéric Royall

11 The Occupy Movement in France

Why Protests Have Not Taken Off

Didier Chabanet and Arnaud Lacheret

12 Conclusion

Place-Based Movements and Macro Transformations

Pascale Dufour, Hélö̈se Nez and Marcos Ancelovici

List of Authors

Index 


\section{List of Tables and Illustrations}

\section{Charts}

Chart 2.1 Euro Area (18) GDP Growth Rate 57

Chart 2.2 Euro Area (18) Unemployment Rate 58

Chart 2.3 Euro Area (18) Youth Unemployment Rate (under 25) 58

Chart 2.4 Euro Area (18) Long-term Unemployment Rate

(12 months and more)

\section{Figures}

Figure 4.1 Proportion of strong supporters relative to the mean, according to left-right position $\quad 102$

Figure 4.2 Two types of engagement in protest, by left-right ideology

Figure 4.3 Two types of engagement in protest, by attitude towards redistribution $\quad 105$

Figure 4.4 Correlates of the left-right cleavage in Spain 105

Figure 4.5 Passive and active support for the Israeli protests by sociopolitical bloc

Figure 4.6 Passive support for the Israeli protests by sociopolitical bloc and fear of future economic distress 108

Figure 4.7 The joint effects of religiosity and leftism on support and participation in the Spanish $15 \mathrm{M}$ protests

Figure 4.8 The joint effects of regional identity and leftism on support and participation in the $15 \mathrm{M}$ demonstrations

Figure 4.9 OLS regressions predicting high passive support or active participation in the $15 \mathrm{M}$ and $14 \mathrm{~J}$ protests

Figure 8.1 Logics of action and their organizational implications

Figure 10.1 Unemployment in Europe (2007-2012): Percentage of total labor force

\section{Graphs}

Graph 6.1 Main Types of Action of the 32 Large Protest Events, January 2010-January 2013

Graph 6.2 Number of Greek Cities and Towns Participating in the 32 LPEs, January 2010-January 2013

Graph 6.3 Number of Non-Greek Cities (in red) Participating in the 32 LPEs, January 2010-January 2013 
Maps

Map 6.1 Total Number of LPEs by Phase of the Anti-Austerity

Campaign in Greek Cities and Towns, January

2010-December 2012

\section{Photos}

Photo 5.1 Memories of the Spanish Civil War 128

Photo 5.2 "Vote and be quiet" 132

Photos 5.3 and 5.4 International References to the Encampment 133

Photos 5.5 and 5.6 Showing the decentralization and the internationalization of the movement $\quad 137$

Tables

Table 4.1 Passive and active participation in the Israeli 14J and Spanish 15 M movements 101

Table 4.2 Cross-country difference in left-right polarization 103

Table 4.3 Cross-country difference in polarization regarding redistribution 105

Table 6.1 Participating Protest Groups, January 2010-January $2013 \quad 158$

Table 7.1 Demographic Characteristics of Occupy Montreal (\%) $\quad 182$ 


\section{Acknowledgements}

Although each chapter can stand alone, this book is based on a comparative perspective that aims to analyze simultaneously the commonalities and specificities of the protests that shook Europe and North America in 2011. It is based on a conference that took place on 21-22 February 2013 at the Université de Montréal. The first day of the conference was open to the public and gave contributors the opportunity to present draft versions of their papers. The second day was a closed workshop in which we discussed specific questions and issues and tried to develop a general framework and argument. We had two additional rounds of discussions in panels at the annual international conference of the Council for European Studies (CES) in Amsterdam, the Netherlands in June 2013 and at the world congress of the International Sociological Association (ISA) in Yokohama, Japan in July 2014.

We would like to thank Patricia García for helping us organize the Montreal conference and Rachel Sarrasin for taking extensive notes during our discussions. We are grateful to the Research Center on Politics and Social Development (www.cpds.umontreal.ca), the Canada Research Chair on Citizenship and Governance (Jane Jenson), and the Faculty of Arts and Sciences of the Université de Montréal for funding and support. We also wish to thank all the contributors to the book for attending the conference, discussing the papers at length, and going through several rounds of revisions. Even though he did not attend the conference, we are glad Hanspeter Kriesi agreed to jump on board and contribute to the volume. We also would like to thank Sophie Béroud, Cristina Flesher Fominaya, Jane Jenson, and Eduardo Romanos for contributing to the Montreal conference and to our discussions. In addition, we benefited from helpful comments and suggestions from Donatella Della Porta and other participants in the CES and ISA panels, as well as Lilian Mathieu and an anonymous reviewer who both examined the manuscript for Amsterdam University Press. Finally, we thank James Jasper for his enthusiastic response to this book and for welcoming us into this new series he edits with Jan Willem Duyvendak. 



\title{
$1 \quad$ Introduction
}

From the Indignados to Occupy: Prospects for Comparison

\author{
Pascale Dufour, Héloïse Nez and Marcos Ancelovici
}

In the spring of 2011, public squares in Spain were taken over by thousands of residents and activists calling for social reforms and a transformation of the political system. The so-called 'Indignados' or 15 May movement (15M movement), as it is known in Spain, is still active today, but its forms of action have changed. Instead of mass demonstrations and occupations of public squares, the movement has developed at the neighborhood level, primarily around housing and social solidarity issues.

Similarly, anti-austerity protests emerged in Greece in the wake of the Spanish 15M movement, with daily gatherings of 'outraged' Greeks in Syntagma Square in Athens. These protests are considered to be a first "peak in the cycle of struggles in Greece against an unpopular government and the patronage of the country under the Troika of the International Monetary Fund (IMF), the European Union (EU) and the European Central Bank (ECB)" (Sotirakopoulos and Sotiropoulos 2013: 1-2).

In Israel, a "sudden and unexpected movement saw 10 percent of Israel's total population go out on the streets" (Grinberg 2013:2) to demand affordable housing and increased economic equality. From mid-July to the beginning of September 2011 (two months prior to the occupation of Wall Street), a massive occupation of public squares led mainly by young people took place throughout the country. This protest received massive support from the population and, for the majority of Israel's observers, was unexpected.

In the fall of 2011, the occupation of public squares crossed the Atlantic Ocean and took hold of New York City, followed by the rest of North America. In Montreal, campers occupied a downtown public square for several weeks until they were evicted by the police on 25 November. Following the example of Occupy Wall Street (OWS), Montreal was one of many North American cities to join the 'Occupy movement.' These mobilizations enjoyed exceptional media coverage and succeeded in pushing the issue of growing socio-economic inequality to the center of the public debate. After the evictions from public squares, the Occupy movement petered out somewhat but carried on in different forms. In Montreal, for example, 
it supported the student movement and participated in the six-month student strike of 2012.

Of course, these events unfolded in specific local contexts. Nevertheless, they also emerged within a specific timeframe, following what has been dubbed the 'Arab Spring', which began in Tunisia in December 2010. For most observers, the mass protests in Tunisia, Egypt, Yemen, and Syria in 2010 and 2011 and the protests in Europe and North America in 2011 belong to the same wave of protests and can be considered together (Interface 2012; Current Sociology 2013; Flesher Fominaya and Cox 2013; Della Porta and Mattoni 2014a). But is the fact that protests emerged more or less simultaneously a sufficient reason to put them in the same category? The main objective of this introductory chapter is to discuss the following question: Do the 2011 protests that shook Europe and North America belong to the same family of protests? And how is it possible to simultaneously study their commonalities and their unique features? These questions lie at the heart of the collective endeavor of this volume. All the chapters are involved in a comparative dialogue which a single researcher could not have carried out alone. In the conclusion of the volume, we will propose some elements and leads for a more systematic comparison.

To facilitate the comparison, we have excluded from our discussion the Arab revolutions as well as the most recent protests in Brazil (2013), Turkey (2013), and Hong Kong (2014). The primary reason for this exclusion is the drastic difference in terms of socio-economic context. The global financial crisis did not hurt all countries equally, with some currently experiencing economic growth while others are deteriorating. Consequently, we chose to focus on a comparison of cases with the highest degree of similarity, thereby reducing the scope of the argument. If we set aside developing countries from our discussion, is it possible to consider the post-2010 protests in Europe and North America as part of the same phenomenon?

This chapter is divided into two main sections. We begin by surveying the growing body of literature on the 2011 protests in different locations, identifying both the hypotheses and the blind spots. We then propose to define this new family of protests on the basis of three dimensions, that is, a political economy, a constitutive tension with representative democracy, and specific modes of action (at least in the initial phases of the protest), suggesting that the issue of diffusion must be included in the analytical framework for the purpose of comparison. 


\section{Abundant Literature but Few Connections to Social Movement Theory}

The Occupy and Indignados movements in Europe, Israel, and North America have given rise to a rich body of literature in the years following their emergence. These publications are nevertheless rather unequal in terms of status, quality, and range of cases covered. We have listed more than 150 references, over half of which cover the $15 \mathrm{M}$ movement in Spain. The others consider the Occupy movement in the United States, Indignados and Occupy in Europe, and the Tent movement in Israel. Some studies have also developed a European or international comparison. To elaborate upon this selection, we have considered books, articles in scientific reviews, and papers presented at the conferences and workshops in which we participated. ${ }^{1}$ We do not, however, claim to be exhaustive. ${ }^{2}$ Many of these publications have a militant tone, blending testimony, analysis, and pamphleteering. We have excluded books authored solely by activists or journalists, scholars' interventions in demonstrations and assemblies, newspaper articles, and blogs. Although some of these interventions are intellectually stimulating and illustrate the high level of reflexivity of the movements' participants, we chose not to engage with them for two main reasons. First, their diversity made any synthesis very hazardous; and second, they were generally framed in normative terms while we wanted this volume to be fully anchored in the sociology of social movements and contentious politics.

The academic literature is plural in and of itself. Numerous pieces have been written by researchers directly involved in the movements and often relying on participant observation and ethnography. They propose a personal interpretation, nourished by a dual belonging. In these cases, authors do not use social science tools to analyze mobilizations as much as they develop positions from their own insider knowledge of movements (in the US, for instance, see Byrne 2012; Gitlin 2012). These publications represent an important contribution to the public debate and the reflexivity of movements in relation to their own practices, but they do not participate in academic debates concerning the nature and dynamics of

1 Most of the chapters in this book were presented at the "Street Politics in the Age of Austerity" Conference (Montreal, 21 February 2013); the $20^{\text {th }}$ International Conference of Europeanists (Amsterdam, 25-27 June 2013); and the Congress of the Spanish Federation of Sociology (Madrid, 10-12 July 2013).

2 This review is limited in particular by language. Our references consist of publications in English, Spanish, French, and Catalan. Greek publications, for example, are not accessible to us. 
social movements. That is the main reason why we do not include their discussion in our review. However, numerous essays written in the heat of the moment describe democratic practices and suggest interpretations of the meaning of these mobilizations (in Spain, for example, see Botella 2011; Nez 2011; Romanos 2011; Serrano 2012; Pestaña 2013). Others have explicitly employed the conceptual apparatus of political science (Welty et al. 2012). But most publications available to date do not rely on fieldwork. They either build upon research conducted on past mobilizations (e.g., the global justice movement) and extrapolate on this basis (Alberich 2012), or they make general claims, for example, concerning the transformation of democracy (Subirats 2011) or the 'principle of democracy' (Ogien and Laugier 2014).

The publications we consider here provide us with some indication of who the protestors are, how protests work, and where they originate. Nevertheless, we still possess very few tools for building a solid comparative argument.

\section{Who Are the Protestors?}

Certain studies have used a quantitative approach to describe the social composition of the mobilizations and the aims and motivations of activists and participants. For example, during the ${ }_{15} \mathrm{M}$ camp, questionnaires were distributed in Salamanca (Calvo et al. 2011) and Bilbao (Arellano et al. 2012) as well as in the New York camp (Panagopoulos 2011). In Spain, data has also been recollected later from a sample of people who participated in the $15 \mathrm{M}$ in Madrid (Likki 2012) and from studies of major demonstrations between 2010 and 2011 (Anduiza et al. 2013a). Other studies in the United States have relied on an online survey (Costanza-Chock 2012b). Calvo (2013) puts in perspective three surveys conducted in Spain (demonstrating that the least politicized participants left the movement after the summer of 2011), and Castells (2012) proposed a synthesis of these data for both Spain and the US. Other North American studies have illustrated that certain categories of the population (particularly those most affected by the economic crisis) were underrepresented in the occupations. For example, Ancelovici (2012) argues that while the collective action frame "We are the $99 \%$ " is effective in mobilizing a wide variety of people, it also conflates very different categories that we need to sort out in order to obtain a solid grasp of the socio-economic inequalities and power relations. In Spain, more classic public opinion studies have also been used to assess the high degree of support for the $15 \mathrm{M}$ movement (CIS 2011; Metroscopia 2011). Among these 
quantitative studies, some have attempted to measure the influence of mobilizations on elections (Jímenez 2011; Anduiza et al. 2013b).

In spite of the methodological problems they raise (problems the authors have acknowledged in certain cases), these studies provide us with important information on the participants' profiles. In Spain, the portrait is actually quite different from the one the media put forward during the 2011 mobilization: the Indignados are not primarily youths directly hurt by the economic crisis, nor do they consist mainly of marginal and anti-system people. In contrast, it is an intergenerational and highly educated movement, strongly supported by national public opinion. Although the students and the unemployed have been involved in the mobilizations, the majority of respondents claim to be in a rather good financial situation but are afraid for their future. Few of them are involved in social or political groups. They vote in greater numbers than the average population, and most of them identify with a left-wing ideology. They are concerned about economic and political issues, and their criticism targets political leaders as well as bankers. Some authors have proposed typologies of participants. For example, Taibo (2013) differentiates Indignados originating from alternative social movements, who make anti-capitalist claims, from those without prior experience, who are more inclined to be moderate. Some results show that the $15 \mathrm{M}$ movement led to an increase in the number of blank and spoiled ballots, which penalized majoritarian parties (especially the Socialist Party, PSOE) during the elections of 2011. Nevertheless, the causal link between the two phenomena (elections and protest) has not been clearly demonstrated. Similarly, although the media have recently paid a significant amount of attention to new Spanish anti-austerity political parties close to social movements - Podemos at the national level and Ganemos at the municipal level - the connection between parties and movements is still pretty much in flux and, in spite of some victories of these new parties in the May 2015 municipal election, it is impossible to determine at this stage the direction it may take.

In the US, the picture is substantially different. According to Milkman, Luce, and Lewis's study (2013), the New York Occupy Wall Street protest was composed mainly of highly educated young adults, with a low rate of ethnic/racial and class diversity. Many had experienced problems with the job market, and those under the age of 30 were burdened by substantial debt. Very few were immigrants. The majority of those actively involved in the movement had previous protest experience (in community groups, unions, anti-war organizations, immigrant rights, human rights or women's rights groups, community groups as well as more traditional political groups). 
Unlike the Spanish protest, the New York protest was less intergenerational in scope. As in Spain, however, the people involved in Occupy Wall Street were not the most marginalized of American society. Though very supportive of Obama in the 2008 election, many were disappointed by his administration while others were already skeptical of representative democracy before the movement emerged.

\section{How Do Protests Work?}

Ethnographic studies primarily question the meaning that activists give to their experiences, especially in terms of organizational practices and internal democracy (Juris 2012; García 2012; Nez 2012; Razsa and Kurnik 2012; Rivero 2012; Estalella and Corsín 2013; Ezquerra and Cruells 2013; Razquin 2014; Nez and Ganuza 2015). These studies highlight the specifics of the Occupy and Indignados movements in their respective contexts (for example, the $15 \mathrm{M}$ in Madrid, Cáceres and an Andalusian town, or Occupy in Boston, Slovenia, and New York). We note a variety of practices and forms of direct democracy: deliberation and consensus are highly valued in general assemblies in Spain and the US; working groups appear to be more autonomous from the general assembly in Slovenia, and consequently most of the activists' time is dedicated to action and concrete activity as opposed to deliberation (Razsa and Kurnik 2012).

In particular, these studies propose a genealogy of the democratic practices of the assemblies, which allows us to understand variations from one location to another. In Spain, several sources of influence overlap: the political culture of the self-organized social centers, a generation of highly educated professionals participating in the assemblies, various forms of discussion on the Internet and social networks, as well as a civic culture open to dialogue (Nez and Ganuza 2012; Ganuza et al. 2013). In Slovenia, the democratic practices implemented originated more from the struggle for migrants' rights, which explains why a slogan such as "We are the $99 \%$ ", with its potential nationalist connotation, was only cautiously received in this country (Razsa and Kurnik 2012).

Furthermore, the practice of direct democracy over time in the assemblies of various Spanish towns indicates that although participants are able to limit the emergence of hierarchies and leaders at the beginning of the process by adopting particular rules with respect to the decision-making process and voicing of opinions, in the longer run the principles of inclusion and horizontality are more difficult to apply because of the specialization of tasks and the defection of participants (García 2012; Nez 2012; Rivero 
2012; Estalella and Corsín 2013; Razquin 2014). In addition, though women have gained more space and visibility compared with previous social movements and though some frames incorporate the intersectionality of inequalities and oppressions (Cruells and Ruiz 2014), interventions and political proposals continue to be spearheaded primarily by men (Ezquerra and Cruells 2013).

As Razsa and Kurnik (2012) argue, ethnography and comparison have a specific role to play in describing and discussing variation in the form and practice of the direct democracy that emerged within the Indignados and Occupy movements. Ethnography can also be used to question the interactions between online and offline mobilizations with a view to testing general assertions according to which a space of autonomous communication between a virtual and physical public space has emerged (Castells 2012). Such an approach would complement contributions that focus on the digital practices of the Indignados and Occupiers, stress the role of the Internet in the consolidation of social mobilization (Arellano et al. 2012; Fuster and Subirats 2012; Gerbaudo 2012; Subirats 2012; Candón and Redondo 2013; Anduiza et al. 2013a) and the emergence of informal political debates (Vicari 2013), and highlight the influence of activists in the development of online practices (Costanza-Chock 2012a). This field of research is still quite recent, and we need more data to be able to understand how virtual and physical protests are related. For example, it is generally taken for granted that the use of social media explains the forms that protests took on and the diffusion they underwent (for example, Candón and Redondo 2013; Gaby and Caren 2012). But we do not know precisely how central and important social media actually are, nor do we know the exact way in which they work.

\section{Where Do the Protests Come From?}

Some of these studies situate the recent protests in relation to previous movements; we are therefore justified in inquiring into the points of continuity and change. Juris (2012), for example, argues that the main difference between the global justice movement and Occupy is the shift from pre-existing group networks to a logic of aggregation of individuals who do not necessarily possess prior activist experience. This shift allows for an expansion of the mobilization to other social categories. These changes are connected to the use of Facebook and Twitter, virtual social networks that enable the convergence of numerous participants to a specific location. This type of activism is more difficult to sustain over time, more difficult to structure around a formal program or set of shared claims, and can be less 
socially and racially inclusive. Adell (2011), who has followed demonstrations in Madrid since the democratic transition in the 1970s, shows that direct links exist between $15 \mathrm{M}$ demonstrations and earlier ones (such as the 2003 protests against the war in Iraq and the 2004 protests related to the Atocha train station bombings in Madrid). Through a detailed description of the $15 \mathrm{M}$ demonstrations, he points out two innovations: participatory democracy practices as well as the Internet and use of live streaming.

Other authors have developed a temporal comparison of movements, using mostly secondary sources to describe previous movements (Baumgarten 2013; Romanos, 2013a). When they do not rely on recent fieldwork, this type of research tends to transpose onto the Occupy and Indignados movements analytical frameworks and theories elaborated to make sense of other cases (Smith and Glidden 2012; Della Porta 2012; Fougier 2012; Flesher Fominaya 2015). The merit of these contributions lies in their search for continuity in collective action, thereby avoiding the pitfall of treating all recent events as new phenomena. They demonstrate that the post-2010 protests amplify or deepen previously existing practices, particularly in autonomous and global justice movements (Maeckelbergh 2012; Shihade, Flesher Fominaya and Cox 2012; Della Porta 2014; Flesher Fominaya 2015). Therefore, autonomous movements in Spain or the global justice movement in the US have much in common with recent protests in terms of claims, action repertoires, and social composition. Various differences have nevertheless been noted with the global justice movement, such as the superiority of the national level as the main target of protest (Della Porta and Mattoni 2014b; Flesher Fominaya 2014), the strength of the territorial anchoring in contrast with the network form (Halvorsen 2012), or the decision-making procedures with the shift from consensus among organizations to consensus among individuals (Aguiton and Haeringer 2012). Some authors also argue that activists from the global justice movements have been spectators rather than leaders in the Occupy and Indignados protests (Fougier 2012).

In Spain, comparisons have been made with the Okupa movement (i.e., squatters' movement), which inspired some of the democratic practices of Indignados and supported them in terms of logistical resources. The $15 \mathrm{M}$, in turn, changed the public perception of the squatters (Abellán, Sequera and Janoschka 2012; Martínez and García 2012). Another comparison includes the free culture movement, which exerts an influence on the $15 \mathrm{M}$ at the level of actors and claims (Fuster 2012; Fuster and Subirats 2012). In the US, pre-existing informal anarchist networks (and ideas) appear to be at the heart of the core group of activists (Milkman et al. 2013; Graeber 2013). 


\section{What Comparisons Can Be Drawn?}

Very few international comparisons can be found in the existing literature, with the vast majority of studies being single case studies, focusing on a city or a country. Specific contexts are identified to explain why the movement, originating in central Spain, failed to find its way into the Basque country (Arellano et al. 2012), or why it followed a specific path in Catalonia (Díaz and Ubasart 2012), or why the massive protests in Israel declined abruptly (Alimi 2012; Gordon 2012; Grinberg 2013). Other studies have attempted to explain the 'failure' of certain cases: in Italy, where political opportunities are unfavorable and where anti-austerity protests compete with the Indignados identity (Zamponi 2012); in Portugal, where the protests rely more on traditional organizations and focus on national issues (Baumgarten 2013; Accornero and Ramos 2014); in Greece, where it is difficult to identify targets and prepare victorious actions in a context of strong police repression (Sotirakopoulos and Sotiropoulos 2013). Some works compare two cases, such as Canada and the US (Ancelovici 2012), Occupy Amsterdam and Occupy Los Angeles (Uitermark and Nicholls 2012), or Occupy Slovenia and Occupy Wall Street (Razsa and Kurnik 2012). In these instances, the continuity of movements is related to their capacity to build strong links with the existing local activist milieu. Finally, some studies adopt an approach explicitly based on the political process model and emphasize political-institutional and organizational variations across European countries (Ancelovici 2015).

Various special issues of journals, certain conference proceedings (Tejerina and Perugorría 2012), and books (Castells 2012; Flesher Fominaya and Cox 2012; Della Porta and Mattoni 2014a) have developed an international comparative perspective with various levels of detail and analysis. Social Movement Studies (2012) dedicated two special issues to Occupy movements in very diverse local and national settings, but this comparison is more a juxtaposition of short texts, sometimes in the absence of a large amount of data, than a real analytical comparison (Pickerill and Krinsky 2012). The special issue of Interface (2012), which attempts to compare three waves of contention (the Arab revolutions, the ${ }_{15} \mathrm{M}$ in Spain, and Occupy in the US), is similar in nature. The American Ethnologist (2012) published a less ambitious but much more coherent special issue at the analytical level. It consists of two very stimulating articles (Razsa and Kurnik 2012; Uitermark and Nicholls 2012) and one comment that generates dialogue on the contributions surrounding certain themes, such as time and temporality, moral imaginaries, and the conception of democracies (Nugent 2012). Nugent demonstrates 
that these movements are rooted in a specific temporality of capitalism, "in which the political is no longer autonomous from the economic" (281). Given increasing levels of social and economic inequality, several articles of the Current Sociology issue (Benski et al. 2013; Langman 2013; Tejerina et al. 2013) also underscore the interest of bringing economic policy back into the study of social movements. This last collective production offers a more integrated comparison between the Indignados and Occupy movements in various countries (Spain, Greece, Portugal, Italy, Israel, and the US) as well as the Arab revolutions, which the issue's coordinators include under the umbrella of a 'new cycle of contention.' In the special issue of Development and Change (2013), the emergence of a new generation of activists and the properties common to the various post-2010 movements are questioned.

Several points of debate cut across such comparative analyses. First, how can we define these movements? Various expressions are used: 'Occupy social movements' in reference to the contentious occupation of public places (Tejerina et al. 2013), 'Activisms 2010+' to emphasize current transformations of activism (Biekart and Fowler 2013), or 'the movements of 2011' which constitute a new global social movement (Glasius and Pleyers 2013). If we look beyond the words, what is at stake is the construction of an analytical object of research and, as a result, the possibility of comparing cases. Until now, the majority of comparative studies have attempted to identify common characteristics, such as the increased role of the Internet and social networks (Castells 2012; Biekart and Fowler 2013), while recognizing that they belong to specific contexts. Some researchers discuss the emergence of a new generation of activists similar to that of 1968 (Gills and Gray 2012; Glasius and Pleyers 2013); others refer to the appearance of "diverse manifestations of a new international cycle of contention" (Tejerina et al. 2013: 1) or of "non-centralized and innovative momentum of multiple protest expressions" (Biekart and Fowler 2013: 532). Several authors propose novel frameworks for analyzing these mobilizations and stress the importance of emotions (Benski and Langman 2013) or the strategic uses of humor (Romanos 2015).

Lastly, in spite of the abundance of references, the literature does not put forward a clear sense of what the post-2010 protests mean. We have a good understanding of how the occupations and demonstrations unfolded and evolved, but we lack empirical studies that deliver a microanalysis of activists' trajectories before, during, and after the protests. This type of microsociology would allow us to address the continuity/change issue in a more focused and grounded manner. Similarly, aside from a few stimulating reflections (Gamson 2011; Romanos 2013b; Roos and Oikonomakis 2014), we 
lack studies that trace the ties and networks (real or virtual) that connect or fail to connect these movements across space. Given that so many questions remain unanswered, does it make sense to group together all the post-2010 protests under a single umbrella?

\section{The Analytical Framework: A New Family of Protests, but Not a Single Movement}

It would appear quite logical at first glance to consider these post-2010 mobilizations as part of a single set of protests for at least two reasons. The first reason is the time period during which they emerged (2010-2012) in a very specific economic context in the US, Canada, and most European countries. These protests are part of a particular temporality of capitalism. Second, activists emphasize (to differing degrees) the failure of the capitalist system and of representative democracy.

However, given that we are questioning the assertion that all of these protests fall in the same category, let us take a closer look. The political process approach suggests the concept of the protest cycle (Tarrow 1994) or waves of contention (Koopmans 2004) to describe a phase of "heightened conflict and contention across the social system" (Tarrow 1994: 153). Tarrow's emphasis on the idea of a cycle suggests a form of iteration over time, while the wave metaphor simply refers to an increase and decrease in the number of protests. Nonetheless, these two expressions suggest at least three interrelated processes:

First, protest waves are characterized by a strong expansion of contention across social groups and sectors, superseding the narrow boundaries of policy fields, and often transcending national borders. Second, protest waves are invariably characterized by a transformation of contention, i.e., changes in strategies, alliance structures, identities, and so forth, which inevitably arise in processes of dynamic interaction and make that no protest wave ends up where it began. That protest waves come to an end is the third seemingly trivial truth, but the reasons for that contraction of contention have commanded little attention in the literature so far. (Koopmans 2004: 21)

The post-2010 protests do not appear to possess the necessary characteristics to fit this definition. First, movements are still too recent to be able to speak of a significant expansion of protest, both in length and scope (except 
perhaps for Greece and Spain). Some authors have even argued that Occupy Wall Street is not a social movement per se but a "moment" of protest and a "dramatic performance" (Calhoun 2013: 35). The 'social movement' category was debated in Spain, where some authors prefer to talk about a "space of mobilization" (Calle 2013), while others contend that a "social movement" is forming as the internal organization of the Indignados becomes more structured (Ibarra 2013). Second, the global diffusion of protest is mostly geographical and much less sectoral in nature, except in certain places such as Spain and Greece. In most locations, there is little or no radicalization or intensification of conflict. In other words, reasoning in terms of a cycle for the post-2010 protests implies a conceptual stretch that undermines the value of such a concept.

As Tejerina et al. (2013) argue, the concept of wave is sustained empirically by common action repertoires (such as the use of social media, see Biekart and Fowler 2013) and frames used by activists during protests (such as rightsbased demands, ibid.). However, as mentioned earlier, very few studies have actually demonstrated the presence of a concrete diffusion process (for an exception, see Della Porta and Mattoni 2014a) or even a transnational coordination of movements. Moreover, we lack the necessary temporal perspective to be able to characterize ongoing mobilizations as part of a cycle of protest. In some countries, struggles are not over. The notion of a 'cycle' has been used in the past as an a posteriori analysis. For example, it was only at the end of the 1980 s that studies showed how a cycle of protest had occurred in Italy, France, and Germany in the 196os and 1970s (Della Porta and Tarrow 1986; Kitschelt 1986; McAdam 1988). Finally, if we want to identify a 'cycle' or a 'wave' - all the more if it is transnational - we need to specify which protests are to be included and which are not. For example, in 2011 and 2012, several contentious episodes involving the student movement took place in Chile (Peñafiel 2012) and Quebec (Ancelovici and Dupuis-Déri 2014). We believe that these protests are not part of the same wave, even if the temporality and some of the claims made are comparable. How can we go about drawing clearer analytical boundaries?

We agree with scholars who state that we must "study and comprehend the local conditions of the specific case" (Grinberg 2013: 493) as well as "the social conflicts and tools used by the dominant groups to maintain their power, and the sequence of events that provoked the political dynamics of protest, including the influence of international waves" (Kriesi et al. 1995:4). In other words, rather than asserting that these events are akin to one another (or considering, for example, that they belong to the same global social movement, see Glasius and Pleyers 2013) or that they can be treated analytically as 
belonging to a single global cycle of protest, we hypothesize that they share a contemporaneity and emerged in a specific global context. Their singularity (demonstrated by testimonies and published studies) should not prevent us from considering them together analytically. But we should not instill them with global meaning a priori. This should be an empirical question.

Notwithstanding their local peculiarities and the different names and labels that activists have used to describe them, three common features stand out. First, all these mobilizations denounce the concentration of wealth and the rise of income inequality at the expense of the vast majority of people, the so-called ' $99 \%$ '. They also all put forward a critique of mainstream institutions and representative democracy. But beyond the actors' discourses and frames, it is important to consider the particular structural context in which these movements emerged (the economic crisis) and determine the manner in which it conditioned and shaped the mobilization. Second, the criticisms directed at representative democracy have specific implications for the social practices and trajectories of these movements. Third, it is possible to trace the process of diffusion that connects them (even if it is a loose connection). These three features underlie the emergence of the post-2010 protests.

\section{The Economic Crisis: More Than a Context for Action}

From the collapse of the American financial sector and the bank bailouts to the bursting of the real estate bubble in Spain and the Euro crisis, the global financial and economic crisis that began in 2008 represents the structural context in which these mobilizations unfolded. This crisis occurred in the wake of a broad trend toward neoliberal deregulation, trade liberalization, offshore manufacturing, welfare retrenchment, and the rising indebtedness of consumers, students, and households. Although the intensity and specifics of the crisis may vary, austerity is spreading among developed countries as it had spread in many Latin American countries in the 1980 s as a result of the debt crisis. The deepening of the social and economic precariousness that affects a significant part of the population constitutes fertile ground for mobilizations and the radicalization of certain ideologies. On the right, nationalist and xenophobic movements are gaining strength. On the left, the picture of a corrupted political-financial elite that underlies the crisis feeds anti-systemic sentiments and contributes to the renewal of sectors of the radical left (e.g., Syriza in Greece and Podemos in Spain).

However, this global context does not automatically generate protests. The latter have been massive in certain instances, as in Greece and Spain, 
but relatively weak in others, even when the crisis was hitting the national economy very hard, as it did in Ireland. How can we make sense of such variations? How has the economic crisis affected mobilizations and protests? Since the 1970s, the social movement literature has focused on cultural, organizational, and political-institutional factors at the expense of socioeconomic ones. Indeed, as Hetland and Goodwin (2013) have highlighted, since the 1970s, we note a "strange disappearance of capitalism from social movement studies". While the changing dynamics of capitalism have been central to the work of Fox Piven and Cloward (1979), Tilly (1978, 1981), Skocpol (1979), and McAdam (1982), more recent studies tend to ignore both the enabling and constraining effects of capitalism on collective action in the short term and long term (for exceptions, see Kousis and Tilly 2005; Della Porta 2015). Rather, the focus has shifted almost exclusively to the state structure, eliminating the explicit link to economic structures and conditions that shape the very grievances and resources at the heart of current mobilizations. "The results are clear and ironic: during an era in which global capitalism became ever more powerful - an era when capitalism triumphed over Soviet-style Communism - it also became increasingly invisible to scholars of popular movements" (Hetland and Goodwin 2013: 90-91).

Nevertheless, in recent publications on the Occupy movement and the Indignados, it would appear that 'capitalism' is back in the analysis. We have observed three possible approaches for analyzing the economic context:

1 The first consists of taking into account the specific economic moment of the emerging protests, in particular the economic crisis of 2008 and its consequences in terms of social cutbacks, increased precarization ${ }^{3}$, unemployment, and pauperization. Here, analyses assume that a link exists between the objective economic situation of activists and protests. The assumption is that the intensity of the crisis will correlate strongly with the level of protest. However, empirical results are not always consistent with this hypothesis: those who took to the streets were not necessarily the ones most hurt by the crisis or the most vulnerable. For example, in France (see the chapter by Chabanet and Lacheret) and, above all, in Ireland (see the chapter by Royall and Desbos), severe recessions and austerity measures were not followed by strong protests. Here, counter-examples and 'negative' cases are important to allow for a better understanding of the dynamics of the protests and their precise links with the effects of the crisis.

3 Precarization refers to the process by which people's working and living conditions become more precarious. 
2 The second approach complexifies the link between capitalism and protests. From this perspective, the Occupy movement is viewed as the product of capitalist contradictions (Langman 2013: 13). Even if the wave of protest has declined, the movement itself will continue over time insofar as the crisis of legitimacy that fostered it has not disappeared. Among the contradictions that the capitalist system produces, the impossibility of economic integration is one of the most discussed. The relative deprivation argument, developed by Gurr (1970), relates a given population's level of expectation of well-being to objective material conditions. In a nutshell, a strong discrepancy between the two is expected to create the conditions for rebellion. This theory has been strongly criticized, mainly for its inability to explain why people tend not to protest even though the conditions are met. In spite of its mechanistic aspect and simplistic expression, we note a return to a variant of the relative deprivation argument. In Spain, for example, young educated students have had rising expectations in terms of employment access and general well-being. The incredibly high level of unemployment for young people (above 5 o per cent for youths under 25) prevents them from fulfilling these expectations, creating a favorable context for (mass) protest (Ibarra 2013).

3 The third approach is based on the idea that an analysis in terms of the political economy of protest could produce multiple results that are not fixed or structurally determined, constituting an empirical puzzle that remains to be solved. Biekart and Fowler (2013: 530-531) advance, for example, two related questions: why did movements emerge precisely when they did, and why did a single protest appear to have spread around the globe? This perspective, which we share, has analytical implications. It requires detailed empirical research to identify: (a) the socio-economic location of activists (and their objective relation with the changing socio-economic structure), AND (b) differences among varieties of capitalism. Put differently, the particular impact of the capitalist structure is circumscribed and left open rather than presumed.

How does the economic crisis affect mobilizations? Hetland and Goodwin (2009: 12) describe four ways in which movements can be affected by the dynamics of capitalism: (1) the impact on identity and solidarity-building; (2) the impact on the evolution of movements and the kind of victories they can expect; (3) the impact on the class balance within movements; and (4) the impact on strategies and goals mediated by the capitalist ideology. 
These points are certainly valid for the post-2010 protests and should be explored further.

A political economy of protest must consider the social composition of the mobilization. Is it a movement of the middle class? In Canada and Israel, there is no serious economic crisis, but there is a middle-class crisis, one that is related to indebtedness and access to education and housing (Rosenhek and Shalev 2013). Given the absence of a financial crisis in these two countries, we have to understand who are the people involved in the protests. One can put forward the hypothesis that the threat of downward mobility or 'déclassement' - where you cannot afford middle class status even if you have the required education and family background - shapes mobilizations in terms of claims, frames, and strategies. Here, there is a clear connection to a kind of 'relative deprivation' argument: those who expected to maintain or improve their living conditions are suddenly faced with the strong probability that they will have less than their parents did. Furthermore, we should not rely on a narrow view of the crisis. In addition to considering the cutbacks in social spending, we must also take into account broader structural transformations of the economy and society in the long term (Joshua 2013). Thus, according to Della Porta:

The evolution of the last 30 years or so has (...) deeply transformed the social structures. Fordism was said to have created a two-thirds society, with new social movements emerging from the pacification of class conflict, and even the embourgeoisement of the working class, with the crisis of the 1970s producing a short but radical wave of protest by the excluded one-third. Today's mobilizations seem instead to reflect the pauperization of the lower classes as well as the proletarianization of the middle classes, with the growth of the excluded in some countries to about two-thirds of the population. (2015:13)

We can push the analysis a little further and ask how varieties of capitalism and welfare regimes are related to protest in the age of austerity. The literature on varieties of capitalism and welfare regimes illustrates how the type of welfare state and historical social institutions have played a role in terms of access to resources, levels of equality (social and political), and the way in which economic crises impact citizens, workers, and families (Palier et al. 2012). For example, the US is very different from southern European countries in terms of who is responsible for the well-being of citizens. In the US, citizens are expected to take care of themselves by working in the labor market; the state is not a major provider of protection. 
In southern European countries, the family and the state are pillars of well-being (Dufour, Boismenu and Noël 2003). Does this difference in terms of welfare mix have an impact on grievances and claims in situations of economic crisis? Could it explain certain types of alliances? Does it affect the intensity of mobilizations or the likelihood of success or failure? Can we relate 'varieties of capitalism' to 'varieties of protest'? And if so, how exactly should we go about doing this? What are the causal mechanisms at play? While several scholars of the welfare state have explored these questions in the past (O'Connor 1993; Pierson 1996; Anderson 2001; Graefe 2004), we believe that social movement scholars have neglected them for too long.

\section{The Political Crisis Dimension at the Heart of Activist Practices}

According to Biekart and Fowler (2013: 532), a clear link exists between current global economic transformations - in particular the disproportionate role of transnational corporations in state affairs - and the reactions of citizens across the globe (i.e., a loss of trust in political parties). In this respect, Activisms 2010+, as Biekart and Fowler call it, can be interpreted as the emerging counterpart of political disaffection and disillusionment. Nevertheless, the connection between the diagnosis of the 'crisis' of representative democracy and mobilizations/protests is not self-evident. This connection is made by protesters (Graeber 2013), but where does it come from?

Commentators often claim that the practice of horizontalism is the lowest common denominator of the recent wave of protest. Such practice is based on direct democracy and non-hierarchical, prefigurative alternatives that allegedly embody the desired ideal society. Another defining feature is the call for autonomy vis-à-vis political parties and other institutional actors such as trade unions. There is a clear rejection of the principles and logic of representative democracy. The 'political crisis' diagnosis appears to express, among other things, a civic desire to be empowered by taking ownership of the polity as opposed to delegating one's power to elected officials. However, as in the case of the economic crisis, the political crisis does not generate discontent automatically. Moreover, the boundary between institutional and extra-institutional actors is not always clear. For example, certain trade unions and political parties support and sometimes actively participate in protests (Calle and Candón 2013; Béroud 2014). We should refrain from taking the current anti-institutional discourse at face value and assuming that it is equally common to all instances of protest. It is an empirical question that needs to be addressed. Furthermore, some activists 
that were criticizing elections and representative democracy in 2011 have, since then, joined existing or new political parties, such as Syriza in Greece or Podemos and Ganemos in Spain.

The literature has approached the democratic preferences and practices of activists from various perspectives:

1 First, some studies consider the political practices employed during the protests. What modes of organization and action (assemblies, open space, occupation) have been developed and are being used? How is consensus rule implemented, and what debates does it generate among participants (see the chapters by Nez and Ancelovici)? What are the possibilities and constraints that this specific mode of organization creates (Kauffman 2011; Nez 2012; Schein 2012; Smith, Castañeda and Heyman 2012)? In particular, the question of continuity/discontinuity of movement and action is central and echoes some of the questions raised during the 1960 s and 1970 in certain self-managed networks (Kitschelt 1993). How do individuals use horizontalism not only in movement assemblies but also in their neighborhoods and everyday lives during and after occupations (Maeckelbergh 2012)? How is it related (or unrelated) to past practices in other activist milieus?

2 Another focus, related to the first, consists of studies that attempt to situate the frames, discourses, emotions, and practices of activists with respect to other movements and organizations in order to explain the particularities of the post-2010 protests (Liboiron 2012; Maeckelbergh 2012; Della Porta and Rucht 2013; Perrugoria and Tejerina 2013). Maeckelbergh (2012) shows, for example, how the practice of occupying public squares during the 15 May movement in Spain built upon and expanded some of the methods developed by the global justice movement (see also Flesher Fominaya 2015). For Juris et al. (2012), the capacity of inclusion of the Occupy movement stems from its use of networking logics to address power differentials within the $99 \%$, even if it created a tension with the basic principles of general assembly and direct participation.

3 Lastly, other types of research focus more on the links (or lack thereof) between protests and other arenas, such as the electoral arena. Generally more quantitative in nature (with some exceptions, such as Fishman 2012), these studies ask whether or not participation in protests affects voting behavior (Jímenez 2011; Anduiza, Mateos and Martin 2013). Unfortunately, we clearly lack studies that systematically explore the actual articulation of different arenas of political participation in order to better understand what the post-2010 protests mean for representative democracies and their transformation. 
Overall, it is not clear whether post-2010 activist practices, ideas, interests, and emotions are really redefining the relationships to institutional politics in Western representative systems. As Agrikoliansky suggests, "recourse to consensus, the importance granted to deliberation, or the absence of a spokesperson, are old practices that have characterized protest movements, from European anarchist groups at the end of the nineteenth century, to the American civil rights movement of the 1950s, and the groups that proliferated in France at the end of the 1980s" (2007: 34). Tracing the history of American social movements in the $20^{\text {th }}$ century, Polletta (2002) demonstrates that activists have found a strategic value in participatory practices. The 'new social movements' in the 196os and 1970s represent an important sequence in this history, and one of their peculiar features was the rejection of the centralized and hierarchical organization of the workers' movement and the promotion of autonomous and decentralized operational structures (Touraine 1985; Berger 1979; Offe 1985; Melucci 1989). These social movements in educational, environmental, and women's struggles defined themselves against institutional politics and thus challenged the boundaries of politics. General assemblies and a strong commitment to internal democracy were preferred, while electing representatives was a suspicious practice. The same concern cuts across the global justice movement, which emerged at the end of the 1990s. The participatory principles put forward by the global justice movement not only expressed adhesion to a value system (Della Porta 2009; Pleyers 2010) but were also a way to address practical problems, such as reconciling diversity and cooperation in a myriad of organizations that included the world social forums (Sommier 2003; Della Porta 2004; Aguiton and Cardon 2005; Agrikoliansky 2007). In this regard, the central characteristic of social movements is to redefine the possibilities of collective action, whatever the period or place considered, and thus to actively participate in the transformation of politics. What is really new in post-2010 protests has yet to be demonstrated.

\section{Post-2010 Protests in a Comparative Perspective: The Issue of Diffusion}

The third feature of the post-2010 protests is directly related to our capacity to compare movements. Beyond structural economic conditions (with all their varieties, as illustrated in the chapter by Ross) and beyond the democratic practices of activists, which vary from place to place, what do we know about the links between protests and their processes of transnationalisation? From a comparative perspective and putting aside the question of similarities or differences between movements, the issue 
of actual connections among them is very interesting and probably the strongest argument in favor of grouping them in a single 'family'.

In the literature on the Occupy and Indignados movements, the question of diffusion is raised by several authors (Castañeda 2012; Kerton 2012; Shihade et al. 2012; Della Porta and Mattoni 2014a). However, only a handful of scholars have conducted empirical studies on the issue, which may be addressed in four ways:

1 From the perspective of contagion or mimetism. The main idea is that movements will find some inspiration abroad and will attempt to establish certain links between their own local protests and other mobilizations abroad. It can be difficult to show precisely how the spirit of the time has a direct or indirect effect on place-based protests, but certain studies have suggested indicators: a comparison of collective action frames, activist discourses, imaginaries, and tools. In a short text that unfortunately contains few empirical elements, Gamson (2011) suggested an understanding of the connections between the Arab Spring and the Israeli Summer on the basis of collective action frames. He shows that 'agency' ("the consciousness that it is posible to alter conditions or policies through collective action", 464) plays a critical role in diffusion from one movement to another (see also Tarrow 2005). As a result, the speed of the dictators' departure in Tunisia and Egypt strengthened the belief in other countries - such as Israel (Gamson 2011) or Spain (Romanos 2013b) - that people can make things happen. In the 1980s, McAdam (1982) used the concept of 'collective self-efficacy' to describe the same kind of phenomenon.

2 Using the genealogy of diffusion processes through an analysis of activists' mobility across national and/or sectoral boundaries (physical or virtual). How do ideas, people, tools, strategies, and tactical and cultural repertoires travel? How are they adapted to local circumstances in other places? Romanos $(2013 \mathrm{~b})$ is one of the few scholars who has studied the transnationalization of the post-2010 protest on the basis of empirical and multi-sites research. Applying the now-classic framework developed by Tarrow (2005) and relying on interviews with Indignados in Madrid and Occupiers in New York, he demonstrates that the influence of the Arab revolutions on the $15 \mathrm{M}$ in Spain is connected to indirect and impersonal channels, while Spanish immigrants and Spanish activists who travelled to New York played an important role in the emergence of Occupy Wall Street and the transmission of knowledge from one camp to another. In this volume, Oikonomakis and Roos propose another original answer to the above questions by developing the concept of 
'resonance' to explain the diffusion of tactics and claims in Spain, Greece, and the US.

3 Examining the issue of continuity/rupture between generations of activists and movements. Diffusion is not only a matter of travelling abroad but also across different periods in the same place. In the case under scrutiny here, what ties have been built (or not been built) with previous movements? What type of learning has taken (or not taken) place? Smith's chapter deals with these issues for Occupy Pittsburgh, which she compares with the US Social Forum. This diachronic comparison across time should be developed to identify the ruptures and the continuities of the Indignados and Occupy movements with previous mobilizations beyond the global justice movement (Flesher Fominaya 2015; Romanos 2013).

4 Comparing simultaneous mobilizations within the same country to trace and assess diffusion processes across movements. This is the case of the mobilization 'waves' in Spain, which emerged in various public service sectors (in Madrid, for instance, the 'green wave' in education, the 'white wave' in health, and so on) to oppose budget cuts and were to some extent inspired by the practices of the Indignados (Adell 2013; Calle and Candón 2013).

All four strategies require very detailed empirical analyses to follow the trajectories of activists and their circulation among activist milieus in their respective country and abroad and through different types of organizations. For example, contending that Occupy was influenced by anarchism is not the same as showing that specific activists who were at the heart of the mobilization process come from anarchist networks and affinity groups. Thus, a combination of micro, meso, and macro-level analysis is needed to address the similarities and differences of post-2010 movements across space and time.

\section{Outline of the Volume}

The great variety of cases discussed in this introduction raises the question of the unit of analysis and the 'comparability' of protests. The media have indeed presented them as different expressions of a single phenomenon. But are we really looking at just one phenomenon? Are 'Occupy' and the 'Indignados' the same? Is relying on similar modes of action and organizational forms (occupations, assemblies, etc.) and denouncing the consequences of the economic crisis or the democratic deficit enough to justify talking 
about a single phenomenon? As discussed above, we argue that, in spite of local peculiarities, all of these mobilizations are part of a broader family of anti-austerity protests. The latter are defined as contentious collective actions targeting austerity policies (cuts in education, housing, health care, pensions, government jobs and services, etc.) implemented by governments under pressure from financial markets and/or supranational institutions in connection with deficit and debt problems (Walton and Ragin 1990: 882).

In order to make sense of, and account for, this family of anti-austerity protests, the contributors to this volume propose two kinds of comparison. The first one is straightforward and implies that some of the chapters $(2,3,4$, and 9) compare several cases. The second one builds on the complementary aspects of a series of single case studies (chapters $5,6,7,8,10$, and 11 ) that are engaged in an empirical and analytical dialogue. Although taken separately, these chapters are not comparative as such, for taken together they put forward a broad and contrasting analysis of the post-2010 protests that a single researcher, or even a small team of researchers, could not have achieved. We believe that this diffused comparative perspective is one of the core assets of this volume.

We have organized this volume into four sections with a view to exploring, analyzing, and comparing this new family of protests:

1 The first section examines the manner in which structural factors shape the current mobilizations. It offers a broader view of the 'crisis' context - both economic (chapter by Ross) and political (chapter by Kriesi) - and the possibility of combining these two contextual dimensions to understand mass protest in a comparative perspective (chapter by Perugorría, Shalev and Tejerina). This last chapter analyzes in particular the role of political cleavages in protests that have attracted mass support, that is, in Spain and Israel.

2 The second section looks closely at the practical and spatial dimensions of activism in three national contexts: in Spain, with Nez's chapter on the localization of the Indignados and their forms of organization and actions; in Greece, with Kousis's chapter on the spatial dimension of the Greek anti-austerity campaign from 2010 to 2013; and in Montreal, with Ancelovici's chapter on the organizational forms of public square occupations and the choice of horizontalism to solve practical problems in the camp.

3 The third section deals with the complex issue of diffusion within a country and among countries. Smith's chapter discusses cross-fertilization and tensions between the global justice movement and Occupy Pittsburgh. Oikonomakis and Roos propose the concept of 'resonance' 
to examine the complex diffusion of collective actions during post-2010 struggles on the basis of participant observation in Spain, Greece, and the US.

4 The last section of this volume explores two 'negative' cases (Desbos and Royall's chapter on Ireland and Chabanet and Lacheret's chapter on France) where a strong movement should have developed given the external opportunities but where internal dynamics among collective actors prevented important protests from emerging. This section aims at avoiding the common problem of selecting on the dependent variable and looking only at 'positive' cases. It thus extends the reach of the comparative perspective of the volume.

Finally, the concluding chapter proposes to answer the main question posed in our introduction: Can we compare? If so, why and how, and what results can we expect to obtain?

\section{Bibliography}

Abellán Jacobo, Sequera Jorge, and Janoschka Michael. 2012. 'Occupying the \#HotelMadrid: A Laboratory for Urban Resistance', Social Movement Studies, 11 (3-4): 320-326.

Accornero Guya, Ramos Pinto. 2015. "Mild Mannered”? Protest and Mobilisation in Portugal under Austerity, 2010-2013', West European Politics, 38 (3-4): 491-515.

Adell Ramon Arguilès. 2011. 'La movilización de los indignados del 15M. Aportaciones desde la sociología de la protesta', Sociedad y Utopía, 38: 141-170.

- 2013. 'Re-movilización social en contexto de crisis', Congress of the Spanish Federation of Sociology, Madrid, July 10, 2013.

Aguiton Christophe, Cardon Dominique. 2005. 'Le Forum et le Réseau: une analyse des modes de gouvernement des réseaux sociaux', Conference "Cultures et pratiques participatives", Paris, 20-21January, Retrieved 5January 2012 from http://actuelmarx.u-parisio.fr/ $\mathrm{cm}_{5} / \mathrm{com} /$ M15_Socio_Aguiton.doc.

Aguiton Christophe, Haeringer Nicolas. 2012. '(S')occuper (de) la gauche, ou l'ignorer?', Mouvements, 69:116-127.

Agrikoliansky Éric. 2007. 'La démocratie entre valeurs et pratiques: le cas des mouvements altermondialistes lors du deuxième Forum social européen', in Neveu C. (ed.), Cultures et pratiques participatives. Paris: l'Harmattan, 33-54.

Alberich Nistal T. 2012. 'Antecedents, Achievements and Challenges of the Spanish Socio-Political Movement ${ }_{15}$ M', in Tejerina Benjamin, Perugorría Ignacia (eds.), From Social to Political: New Forms of Mobilization and Democratization. Bilbao: Universidad del País Vasco, 74-88.

Alimi Eitan Y. 2012. “'Occupy Israel”: A Tale of Startling Success and Hopeful Failure', Social Movement Studies, 11 (3-4): 402-407.

Ancelovici Marcos. 2012. 'Le mouvement Occupy et la question des inégalités: ce que le slogan “Nous sommes les 99\%” dit et ne dit pas', in Dupuis-Déri F. (ed.), Par-dessus le marché! Réflexions critiques sur le capitalisme, Montréal: Les éditions Écosociété, 15-48. 
-. 2015. 'Crisis and Contention in Europe: A Political Process Account of Anti-Austerity Protests', in Trenz H.-J., Guiraudon V., Ruzza C. (eds.), Europe's Prolonged Crisis: The Making or the Unmaking of a Political Union. London: Palgrave, 189-209.

Ancelovici Marcos, Dupuis-Déri Francis (eds.). 2014. Un Printemps rouge et noir: Regards croisés sur la grève étudiante de 2012. Montreal: Écosociété.

Anderson Karen M. 2001. 'The politics of retrenchment in a social democratic welfare state. Reforms of Swedish pensions and unemployment insurance', Comparative Political Studies, 34 (9): 1063-1091.

Anduiza Eva et al. 2013a. 'Mobilization through Online Social Networks: The Political Protest of the Indignados in Spain', Information, Communication \& Society, 17 (6): 1-15.

-. 2013b. 'Las consecuencias electorales del ${ }_{15} \mathrm{M}$ ', in Anduiza Eva et al. (eds.), Las elecciones generales de 2011. Madrid: CIS, 145-66.

Arellano Javier et al. 2012. '55-M Bilbao: Estudio de dinámicas sociales en torno a las movilizaciones del 15-M en Bilbao', Vitoria Gasteiz: Servicio Central de publicaciones del Gobierno Vasco.

Baumgarten Britta. 2013. 'Geração à Rasca and beyond: Mobilizations in Portugal after 12 March 2011', Current Sociology, 61: 457-473.

Benski Tova, Langman Lauren. 2013. 'The effects of affects: The place of emotions in the mobilizations of 2011', Current Sociology, 61: 525-540.

Benski Tova et al. 2013. 'From the streets and squares to social movement studies: What have we learned?', Current Sociology, 61: 541-561.

Berger Sophie. 1979. 'Politics and Anti-politics in Western Europe in the 7os', Daedalus, 108 (1): 27-50.

Béroud Sophie. 2014. 'Crise économique et contestation sociale en Espagne: des syndicats percutés par les mouvements sociaux?', Critique internationale, 65:27-42.

Biekart Kees, Fowler Alan. 2013. 'Transforming Activisms 2010+: Exploring Ways and Waves', Development and Change, 44 (3): 527-546.

Botella-Ordinas Eva. 2011. 'La démocratie directe de la Puerta del Sol', La Vie des idées. Retrieved 24 May 2011 from http://www.laviedesidees.fr/La-democratie-directe-de-la-Puerta.html.

Byrne Janet. 2012. The Occupy Handbook. New York: Back Bay Books.

Calhoun C. 2013. 'Occupy Wall Street in perspective', British Journal of Sociology, 64 (1): 26-38.

Calle Ángel. 2013. 'Democracias emergentes. Movilizaciones para el siglo XXI', in Cruells Marta, Ibarra Pedro (eds.), La democracia del futuro: del ${ }_{15} \mathrm{M}$ a la emergencia de una sociedad civil viva. Madrid: Icaria Editorial, 169-177.

Calle Ángel, Candón José. 2013. 'Sindicalismo y 15M', in Cruells Marta, Ibarra Pedro (eds.), $L a$ democracia del futuro: del ${ }_{15} \mathrm{M}$ a la emergencia de una sociedad civil viva. Madrid: Icaria Editorial, $151-167$.

Calvo Kerman. 2013. 'Fighting for a voice: the Spanish 15-M movement', in Flesher Fominaya Cristina, Cox Laurence (eds.), Understanding European Movements. New Social Movements, Global Justice Struggles, Anti-Austerity Protest. London: Routledge, 236-245.

Calvo Kerman et al. 2011. 'Movimiento 15M: ¿quiénes son y qué reivindican?', Zoom Político, Fundación Alternativas, 4: 4-17.

Candón José, Redondo Diana. 2013. 'Redes digitales y su papel en la movilización', in Cruells Marta, Ibarra Pedro (eds.), La democracia del futuro: del 15 M a la emergencia de una sociedad civil viva. Madrid: Icaria Editorial, 103-129.

Castañeda Ernesto. 2012. 'The Indignados of Spain: A Precedent to Occupy Wall Street', Social Movement Studies, 11 (3-4): 309-319.

Castells Manuel. 2012. Redes de indignación y esperanza. Madrid: Alianza Editorial.

CIS. 2011. Barómetro de junio. Estudio no 2, 905. 
Costanza-Chock Sacha. 2012a. 'Mic Check! Media Cultures and the Occupy Movement', Social Movement Studies, 11 (3-4): 375-385.

- 2012b. 'Preliminary Findings: Occupy Research Demographic and Political Participation Survey 2012', Occupy Research. Retrieved 30 March 2012 from http://www.occupyresearch. net/2012/03/23/preliminary-fındings-occupy-research-demographic-and-politicalparticipation-survey/.

Cruells Marta, Ruiz Sonia. 2014. 'Political Intersectionality within the Spanish Indignados Social Movement', in Woehrle L.M. (ed.), Research in Social Movements, Conflicts and Change, 37: 3-25.

Current Sociology. 2013. 'Special Issue. From Indignation to Occupation: A New Wave of Global Mobilization', 61 (4): 377-561.

Della Porta Donatella. 2004. 'Démocratie en mouvement: les manifestants du Forum social européen, des liens aux réseaux', Politix, 17 (68): 49-77.

- (ed.). 2009. Democracy in Social Movements. Houndsmill: Palgrave.

- 2012. 'Mobilizing against the crisis, mobilizing for "another democracy": Comparing two global waves of protest', Interface, 4 (1): 274-277.

—. 2014. 'Learning Democracy: Cross-Time Adaptation in Organisational Repertoires', in Della Porta Donatella, Mattoni Alice (eds.), Spreading Protest. Social Movements in Times of Crisis, Colchester: ECPR Press, 43-69.

- 2015. Social Movements in Times of Austerity: Bringing Capitalism Back in Protest Analysis. London: Polity.

Della Porta, Donatella, Mattoni Alice (eds.). 2014a. Spreading Protest. Social Movements in Times of Crisis, Colchester: ECPR Press.

- 2014b. 'Patterns of Diffusion and the Transnational Dimension of Protest in the Movements of the Crisis: An Introduction', in Della Porta D., Mattoni A. (eds.), Spreading Protest. Social Movements in Times of Crisis, Colchester: ECPR Press, 1-18.

Della Porta Donatella, Rucht Dietrich. 2013. Meeting Democracy. Power and Deliberation in Global Justice Movements. Cambridge: Cambridge University Press.

Della Porta Donatella, Tarrow Sidney. 1986. 'Unwanted children: Political violence and the cycle of protest in Italy, 1966-1973', European Journal of Political Research, 14 (5-6): 607-632.

Development and Change. 2013. 'Debate: Transforming activisms', 44 (3): 527-704.

Díaz-Cortés Fabià, Ubasart-Gonzàlez Gemma. 2012. '15M: Trajectòries mobilitzadores i especificitats territorials. El cas català', Interface, 4 (1): 235-250.

Dufour Pascale, Boismenu Gérard, Noël Alain. 2003. L'aide au conditionnel. Montréal: Les Presses de l'Université de Montréal.

Estalella Adolfo, Corsín Alberto. 2013. 'Asambleas populares: el ritmo urbano de una política de la experimentación', in Cruells Marta, Ibarra Pedro (eds.), La democracia del futuro: del ${ }_{15} \mathrm{M}$ a la emergencia de una sociedad civil viva. Madrid: Icaria Editorial, 61-79.

Ezquerra Sandra, Cruells Marta. 2013. 'Movilización, discursos y prácticas feministas del ${ }_{15} \mathrm{M}$ ', in Cruells Marta, Ibarra Pedro (eds.), La democracia del futuro: del $15 \mathrm{M}$ a la emergencia de una sociedad civil viva. Madrid: Icaria Editorial, 131-149.

Fishman Robert. 2012. 'On the Significance of Public Protest in Spanish Democracy', in Jordana Jacint, Navarro Vinceç, Pallarés Franscec, Requejo Ferran (eds.), Democràcia, Política I Societat. Homenatge a Rosa Virós, Barcelona: Universitat Pompeu Fabra, 351-366.

Flesher Fominaya Cristina. 2014. Social Movements and Globalization. How Protests, Occupations, and Uprisings are Changing the World. Basingstoke: Palgrave Macmillan.

—. 2015. 'Debunking Spontaneity: Spain's 15-M/Indignados as Autonomous Movement', Social Movement Studies, 14 (2): 142-163. 
Flesher Fominaya Cristina, Cox Laurence (eds.). 2013. Understanding European Movements. New Social Movements, Global Justice Struggles, Anti-Austerity Protest. London: Routledge.

Fougier Eddy. 2012. 'De l'altermondialisme aux “Indignés”: un nouveau souffle pour la contestation du capitalisme?', Revue internationale et stratégique, 86: 26-36.

Fox Piven Frances, Cloward Richard.A. 1979. Poor Peoples Movements. How they Suceed, How they Fail. New York: Vintage Books.

Fuster Morell. 2012. 'The Free Culture and 15M Movements in Spain: Composition, Social Networks and Synergies', Social Movement Studies, 11 (3-4): 386-392.

Fuster Morell, Subirats Joan. 2012. Més enllà d'Internet com a eina "martell" - eina de la vella política: Cap un nou Policy Making? Els casos del Moviment de Cultura Lliure i pel Procomú Digital i el 15M a Catalunya, Escola d'Administració Pública de Catalunya. Retrieved 1o May 2011 from http://bit.ly/HhGzcJ.

Gaby Sarah, Caren Neal. 2012. 'Occupy Online: How Cute Old Men and Malcolm X Recruited 400,00o US Users to OWS on Facebook', Social Movement Studies, 11 (3-4): 454-456.

Gamson William A. 2011. 'Arab Spring, Israeli summer and the process of cognitive liberation', Swiss Political Science Review, 17: 463-468.

Ganuza Ernesto et al. 2013. 'El imaginario cívico y el 15M: ¿qué pasó antes del 15 de mayo del 2011?', Congress of the Spanish Federation of Sociology, Madrid, July 10, 2013.

García Patricia. 2012. 'El 15M: de vuelta al barrio como espacio de lo político', Revista internacional de pensamiento político, 7:291-310.

Gerbaudo Paolo. 2012. Tweets and the Streets: Social Media and Contemporary Activism. London: Pluto Press.

Gills Barry K., Gray Kevin. 2012. 'People Power in the era of Global Crisis: Rebellion, Resistance, and Liberation', Third World Quaterly, 33 (2): 205-224.

Gitlin Todd. 2012. Occupy Nations: The Roots, the Spirit, and the Promise of Occupy Wall Street. London: HarperCollins Publishers.

Glasius Marlies, Pleyers Geoffrey. 2013. 'The Global Moment of 2011: Democracy, Social Justice and Dignity', Development and Change, 44 (3): 547-567.

Gordon Uri. 2012. 'Israel's “Tent Protests”: The Chilling Effect of Nationalism', Social Movement Studies, $11(3-4):$ 349-355.

Graeber David. 2013. The Democratic Project: An Idea, a History, a movement. New York: Sipegel \& Grau.

Graefe Peter. 2004. 'Personal Services in the Post-industrial Economy: Adding Nonprofits to the Welfare Mix', Social Policy \& Administration, 38 (5): 456-469.

Grinberg Lev Luis 2013. 'The J14 resistance mo(ve)ment: The Israeli mix of Tahrir Square and Puerta del Sol', Current Sociology, 61 (4): 491-509.

Gurr Ted R. 1970. Why Men Rebel. Princeton: Princeton University Press.

Halvorsen Sam. 2012. 'Beyond the Network? Occupy London and the Global Movement', Social Movement Studies, 11 (3-4): 427-433.

Hetland Gabriel, Goodwin Jeff. 2013. 'The Strange Disappearance of Capitalism from Social Movement Studies', in Barker Colin. et al. (eds.), Marxism and Social Movements. Leiden/ Boston: Brill, 83-102.

Ibarra Pedro. 2013. 'Introducción', in Cruells Marta, Ibarra Pedro (eds.), La democracia del futuro: del 15 M a la emergencia de una sociedad civil viva. Madrid: Icaria Editorial, 5-15.

Interface. 2012. 'Special section: A new wave of European mobilizations?' 4 (1): 183-286.

Jímenez Sànchez Manuel. 2011. ‘¿Influyó el 15M en las elecciones municipales?’, Zoom Político, Fundación Alternativas, 4:18-28. 
Johsua Florence. 2013. 'Repenser la production sociale de la révolte. À partir d'une étude des transformations du recrutement à la LCR depuis 2002', Revue française de science politique, 63: 841-864.

Juris Jeffrey S. 2012. 'Reflections on \#Occupy Everywhere: Social media, public space, and emerging logics of aggregation', American Ethnologist, 39 (2): 259-279.

Juris Jeffrey S. et al. 2012. 'Negotiating power and Difference within the 99\%', Social Movement Studies, $11(3-4)$ : 434-440.

Kauffman L.A. 2011. 'The Theology of Consensus', in Gessen Keith et al. (eds.), Occupy! Scenes from Occupied America. London: Verso, 46-51.

Kitschelt Hanspeter P. 1986. 'Political Opportunity Structures and Political Protest: Anti-Nuclear Movements in Four Democracies', British Journal of Political Science, 16 (1): 57-85.

- 1993. 'Social Movements, Political Parties and Democratic Theory', Annals of the American academy of Political and Social Science, 528:13-29.

Kerton Sarah. 2012. 'Tahrir, Here? The Influence of the Arab Uprisings on the Emergence of Occupy', Social Movement Studies, 11 (3-4): 302-308.

Koopmans Ruud. 2004. 'Protest in Time and Space: The Evolution of waves of Contention', in Snow David A. et al. (eds.), The Blackwell Companion to Social Movements. Oxford: Blackwell Publishing, 20-46.

Kousis Maria, Tilly Charles. 2005. Economic and Political Contentious in Comparative Perspective. Boulder: Paradigm Publishers.

Kriesi Hanspeter et al. 1995. New Social Movements in Western Europe. A Comparative Analysis. Minneapolis: Univesity of Minnesota Press.

Langman Lauren. 2013. 'Occupy: A new new social movement', Current Sociology, 61: 510-524.

Liboiron Max. 2012. 'Tactics of Waste, Dirt and Discard in the Occupy Movement', Social Movement Studies, 11 (3-4): 393-401.

Likki Tiina. 2012. '15M Revisited: A Diverse Movement United for Change', Zoom Político, Fundación Alternativas, 11.

Maeckelbergh Marianne. 2012. 'Horizontal democracy now: from alterglobalization to occupation', Interface, 4 (1): 207-234.

Martínez Miguel Á., García Ángela. 2012. 'Ocupar las plazas, liberar los edificios'. Retrieved 2 May 2013 from http://www.miguelangelmartinez.net/IMG/pdf/15m_MARTINEZ-GARCIA_v5.pdf.

McAdam Doug. 1982. Political Process and the Development of Black Insurgency 1930-1970. Chicago: University of Chicago Press.

McAdam Doug. 1988. Freedom Summer. New York/Oxford: Oxford University Press.

Melucci Alberto. 1989. Nomads of the Present. London: Routledge.

Metroscopia. 2011. Opinión de los españoles ante el $15 \mathrm{M}$.

Milkman Ruth et al. 2013. Changing the subject: a bottom-up account of Occupy Wall Street in New York City, Retrieved 3 May 2013 from http://sps.cuny.edu/filestore/1/5/7/1_a05051d2117 901d/1571_92f562221b8041e.pdf.

Nez Héloïse. 2011. 'No es un botellón, es la revolución! Le mouvement des indignés à Puerta del Sol, Madrid', Mouvements. Retrieved 7 June 2011 from http://www.mouvements.info/ No-es-un-botellon-es-la-revolucion.html.

—. 2012. 'Délibérer au sein d'un mouvement social: ethnographie des assemblées des Indignés à Madrid', Participations, 3: 79-101.

Nez Héloïse, Ganuza Ernesto. Forthcoming. 'Among Militants and Deliberative Laboratories: The Indignados', in Tejerina Benjamín, Perugorría Ignacia (eds.), Crisis and Social Mobilization in Contemporary Spain: The M15 Movement, Farnham: Ashgate. 
Nugent David. 2012. 'Commentary: Democracy, temporalities of capitalism, and dilemmas of inclusion in Occupy movements', American Ethnologist, 39 (2): 280-283.

O'Connor Julia S. 1993. 'Gender, class and citizenship in the comparative analysis of welfare state regimes: theoretical and methodological issues', British Journal of Sociology, 44 (3): 501-518.

Offe Klaus. 1985. 'New social movements: Challenging the Boundaries of institutional politics', Social research, $5^{2}(4): 829-868$.

Ogien Albert, Laugier Sandra. 2014. Le principe démocratie. Enquête sur les nouvelles formes du politique. Paris: La Découverte.

Palier Bruno et al. (eds.). 2012. The age of dualization, the changing face of inequality in deindustrializing societies. Oxford: Oxford University Press.

Panagopoulos Costas. 2011. 'Occupy Wall Street Survey Results', Department of Political Science, Fordham University. Retrieved 3 May 2013: http://www.fordham.edu/images/academics/ graduate_schools/gsas/elections_and_campaign_/occupy\%2owall\%2ostreet\%2osurvey\%20 results\%20102611.pdf.

Peñafiel Ricardo. 2012. 'Le "printemps chilien" et la radicalisation de l'action collective contestataire en Amérique latine', Lien social et Politiques, 68: 121-140.

Perugorría Ignacia, Tejerina Benjamín. 2013. 'Politics of the encounter: Cognition, emotions, and networks in the Spanish 15M', Current Sociology, 61: 524-542.

Pestaña Moreno, José Luis. 2013. 'Vie et mort des assemblées', La vie des idées. Retrieved 25 March 2011 from http://www.laviedesidees.fr/Vie-et-mort-des-assemblees.html.

Pickerill Jenny, Krinsky John. 2012. 'Why Does Occupy Matter?' Social Movement Studies, 11 (3-4): 279-287.

Pierson Paul. 1996. 'The new politics of the welfare state', World Politics, 48 (2): 143-179.

Pleyers Geoffrey. 2010. Alter-Globalization. Becoming Actors in the Global Age. Cambridge: Polity.

Polletta Francesca. 2002. Freedom is an endless meeting. Democracy in American Social Movements. Chicago: The Chicago University Press.

Razquin Adriana. 2014. 'Tomar la palabra en el 15M: Condiciones sociales de acceso a la participación en la asamblea', $\mathrm{PhD}$ thesis, Arte y humanidades, Universidad de Cádiz.

Razsa Maple, Kurnik Andrej. 2012. 'The Occupy Movement in Žižek's hometown: Direct democracy and a politics of becoming', American Ethnologist, 39 (2): 238-258.

Rivero Jiménez, Borja. 2012. 'The Assemblies of 15th May Movement in Cáceres: An Example of Democracy School, a Road to Dialogic Society' in Tejerina Benjamín, Perugorría Ignacia (eds.), From Social to Political: New Forms of Mobilization and Democratization. Bilbao: Universidad del País Vasco, 108-118.

Romanos Eduardo. 2011. 'Les Indignés et la démocratie des mouvements sociaux', Retrieved 18 November 2011 from http://www.laviedesidees.fr/IMG/pdf/20111118_romanos.pdf.

-. 2013a. 'Collective Learning Processes within Social Movements: Some Insights into the Spanish 15M/Indignados Movement', in Flesher Fominaya C., Cox L. (eds.), Understanding European Movements. New Social Movements, GlobalJustice Struggles, Anti-Austerity Protest. London: Routledge, 203-219.

-.2013b. 'From Tahrir to Puerta del Sol to Wall Street: A Comparison of Two Diffusion Processes within the New Transnational Wave of Protest', Conference "Street Politics in the Age of Austerity", Montreal, 21 February.

—. Forthcoming. 'The Strategic Use of Humor in the Spanish Indignados / 15M Movement', in Tejerina Benjamín, Perugorría Ignacia (eds.), Crisis and Social Mobilization in Contemporary Spain. Farnham: Ashgate. 
Roos Jerome, Oikonomakis Leonidas. 2014. 'They Don't Represent Us! The Global Resonance of the Real Democracy Movement from the Indignados to Occupy', in Della Porta D., Mattoni A. (eds.), Spreading Protest. Social Movements in Times of Crisis. Colchester: ECPR Press, 117-136.

Rosenhek Zeev, Shalev Michael. 2013. 'The political economy of Israel's "social justice” protests: a class and generational analysis', Contemporary Social Science, Retrieved o5 November 2013 from http://pluto.huji.ac.il/ mshalev/Papers/Rosenhek-Shalev\%2oIsraeli\%2oprotest_Cont\%2oSoc\%2oSci.pdf.

Schein Rebecca. 2012. 'Whose Occupation? Homelessness and the Politics of Park Encampments', Social Movement Studies, 11 (3-4): 335-341.

Serrano Juan E. 2012. 'Ethnographie de l'acampada. La politisation à marche forcée de la génération perdue', Multitudes, 50: 75-79.

Shihade Magid, Flesher Fominaya Cristina, Cox Laurence. 2012. 'The season of revolution: the Arab Spring and European mobilizations', Interface, 4 (1):1-16.

Skocpol Theda. 1979. States and Social revolutions. Cambridge: Cambridge University Press.

Smith Curtis. et al. 2012. 'The Homeless and Occupy El Paso: Creating Community among the 99\%', Social Movement Studies, 11 (3-4): 356-366.

Smith Jackie, Glidden Bob. 2012. 'Occupy Pittsburgh and the Challenges of Participatory Democracy', Social Movement Studies, 11 (3-4): 288-294.

Social Movement Studies. 2012. 'Special issue: Occupy!', 11 (3-4): 1474-2837.

Sommier Isabelle. 2003. Le renouveau des mouvements contestataires à l'heure de la mondialisation. Paris: Flammarion.

Sotirakopoulos Nikos, Rootes Christopher. 2014. 'Occupy London in International and Local Context', in Della Porta Donatella, Mattoni Alice (eds.), Spreading Protest: Social Movements in Times of Crisis, Colchester: ECPR Press, 171-92.

Sotirakopoulos Nikos, Sotiropoulos George. 2013. "'Direct democracy now!": The Greek indignados and the present cycle of struggles', Current Sociology, 61: 443-456.

Subirats Joan. 2011. Otra sociedad ¿Otra política? De "no nos representan" a la democracia de lo común. Barcelona: Icaria.

—. 2012. 'Algunas ideas sobre política y políticas en el cambio de época: Retos asociados a la nueva sociedad y a los movimientos sociales emergentes', Interface, 4 (1): 278-286.

Taibo Carlos. 2013. 'The Spanish indignados: A movement with two souls', European Urban and Regional Studies, 20: 155-158.

Tarrow Sydney. 1994. Power in Movement: Social Movements, Collective action and Politics. Cambridge: Cambridge University Press.

-. 2005. The New Transnational Activism. Cambridge: Cambridge University Press.

Tejerina Benjamín, Perugorría Ignacia (eds.). 2012. From Social to Political: New Forms of Mobilization and Democratization. Bilbao, Universidad del País Vasco.

Tejerina Benjamín. et al. 2013. 'From indignation to occupation: A new wave of global mobilization', Current Sociology, 61: 377-392.

The American Ethnologist. 2012. 'Occupy Movements: AE Forum', 39 (2).

Tilly Charles. 1978. From Mobilization to Revolution. New York: Random House.

-.1981. As Sociology Meets History. New York: Academic Press.

Touraine Alain. 1985. 'An introduction to the Study of Social Movements'. Social Research, $5^{2}$ (4): $749-787$.

Uitermark J., Nicholls W. 2012. 'How local Networks Shape a Global Movement: Comparing Occupy in Amsterdam and Los Angeles', Social Movement Studies, 11 (3-4): 295-301.

Vicari S. 2013. 'Public reasoning around social contention: A case study of Twitter use in the Italian mobilization for global change', Current Sociology, 61: 474-49o. 
Walton J., Ragin C. 1990. 'Global and National Sources of Political Protest:Third World Responses to the Debt Crisis', American Sociological Review, 55: 876-89o.

Welty E. et al. (eds.). 2012. Occupying Political Science: The Occupy Wall Street Movement from New York to the World. Houndsmill: Palgrave Macmillan.

Zamponi Lorenzo. 2012. 'Why don't Italians Occupy? Hypotheses on a Failed Mobilization', Social Movements Studies, 11 (3-4): 416-426. 
Part 1

How Structural Factors Shape Mobilization 



\title{
$2 \quad$ Austerity and New Spaces for Protest
}

\author{
The Financial Crisis and Its Victims
}

George Ross

The first major economic crisis of the $21^{\text {st }}$ century is comparable to the 'Great Depression' after 1929. Like its $20^{\text {th }}$ century predecessor, the epicenter has been the US and Wall Street. The 2008 collapse of Lehman Brothers is its symbolic core, with the City of London not far away. The major differences with 1929 are the dense web of financial globalization and new technologies. The disaster has had two distinct phases. The first involved the collapse of major Anglo-American financial institutions that led to a credit crisis and a crippling of the 'real economy'. The second began with contagion from the US-UK crisis to the Eurozone, the group of EU members belonging to Economic and Monetary Union (EMU), which wrought havoc on EMU's poorer members, the EMU itself, and the EU more broadly. The origins of both phases are now well understood, as are the public policies proposed to restore economic health. The results are less clear, however. Recovery from both crises has been halting, and their consequences will take many years to be clear.

Large financial crises change social structures, disrupt lives, and shatter shared understandings of the world, leaving millions confused, uncertain, and forced to cope with disrupted lives. Most people submit and improvise solutions on their own, for better or worse. Large crises can also, however, produce unpredictable anger, collective mobilization, protest, and large political changes. The distribution of protest responses depends on both social and political variables and the creativity of protest actors. The years after 1929 provide many, sometimes unpleasant illustrations. There was rapid contagion of fascist movements practically everywhere, for example, threatening fragile democracies and incorporating intolerance, violence, and, in time, militarism. The Great Depression devastated working classes but eventually stimulated new workplace militancy, changed trade unions, and spawned innovative approaches to social reform. Looking back on all this from the post-1945 years, the cornucopia of social protest that occurred fed brutal warfare but also helped recast politics, economics, and social structures in more positive ways.

Epochal capitalist crises have usually begun in financial sectors and spread throughout economies and societies. As this happens, 'real 
economies' collapse, often because credit and investment capital dry up, production and consumption decline, stock markets implode, and transnational contagion often follows. One of the central tasks of governments is to prevent such processes, and if they cannot do so, to try and stop things from getting worse. This chapter will first review the American crisis that began in 2007-2008, providing an overview of what happened and the economic and social damages that it caused. We will then do the same for the Eurozone-EMU crisis. We will also be looking at seriously hurt social groups from whom, according to some theories, protest might be likely to come. It is important to be clear, however, that social protest does not automatically follow from structural changes. Groups that are devastatingly hurt are as likely not to protest as to do so. Explaining protest and the forms that it assumes are difficult matters that cannot be answered by consulting the map of crisis-induced social disruption that we will provide. The hard work of answering questions such as 'Why do protesters protest?' and 'Why do they protest in the ways they do?' is the task of colleagues in the rest of this volume.

\section{Wall Street to Our Street}

Big economic crises have many causes. The 'Great Recession' began when an out-of-control American housing bubble burst (Chinn and Frieden 2011; Blinder 2013). Home ownership has been an important part of the 'American dream' for a very long time, and even if the excesses of housing markets have been the source of several crises, the payoffs of encouraging wider home ownership have been difficult for politicians to resist. In the 1990s, Bill Clinton rewrote national legislation and instructed Fannie Mae and Freddie Mac, two huge government-supported providers of mortgage funding, to loosen their lending standards. Home ownership grew significantly thereafter. The Clinton administration, whose financial leaders were high-level Wall Streeters, also furthered the deregulation that had begun in the later 1970 s by repealing central parts of the New Deal Glass-Steagall Act to allow greater overlap between banks, investment houses, insurance companies, and other financial institutions. Clinton was also a powerful promoter of American globalization strategies, facilitating the international diffusion of AngloAmerican financial practices that would later help spread the crisis (Panitch and Gindin 2012). Clinton's policies set the table for what would follow.

The crisis culprit most often named is Alan Greenspan, neoliberal financial guru and Chairman of the US Federal Reserve from 1987 to 2006. 
One high point of his Fed leadership, seen at the time as financial policy genius, was lowering interest rates to 1 percent in the early 2000 s to prop up the US economy after $9 / 11$ and the collapse of the dotcom boom - and to keep them low for several years thereafter. This dropped borrowing costs on everything, including housing, and stimulated a gold rush in housing loans. Greenspan was also an important supporter of the view, shared by financiers and economists alike at the time, that self-regulating, self-correcting markets priced products accurately, that financial market innovations spurred broader economic success, and that American capitalism in the early $21^{\text {st }}$ century had achieved a miraculous 'Great Moderation' of steady, robust growth without inflation. Rising interest rates to rein in the Greenspan bubble coupled with a housing market downturn that followed almost immediately after Greenspan left the Fed were the factors that caused the US housing market to collapse.

Some analysts also accuse a foreign culprit. China, in the full bloom of emerging market growth, manipulated exchange rates to increase its exports and to accumulate vast reserves. These policies were subsequently blamed for creating an international 'savings glut' and accentuating dangerous imbalances in globalization. China benefited because these policies increased exports, growth, and rapid industrialization. The US also benefited because it could draw on the savings of rapidly growing export-oriented countries like China to help finance American consumption. ${ }^{1}$ Put another way, the Chinese invested their collective savings in US financial markets in ways that allowed Americans to live well beyond their means, supported by the US's unique position as an international financial haven, in particular by consuming imported Chinese goods on credit and by floating the housing bubble (Eichengreen 2010a; Streeck 2011; Pettis 2012). The availability of cheap imported goods and vast consumer credit also masked the dangers of an American development strategy that pushed income and other inequalities to levels not seen since 1929. These conditions also created a vast increase in financial sector profits, allowing the financial sector to gain even greater influence over US economic governance.

The deeper mechanisms behind the imminent disaster of crisis lay in the risky practices of the financial sector. First, the real estate and mortgage

1 This argument underplays one of the rationales for Chinese practices. The 1997 South Asian crisis involved overnight outflows of Western investment ('hot money') that then obliged affected countries to implement tough restructuring reforms. The Chinese concluded that they should always have sufficient reserves to prevent this from happening again. These reserves had to be put in a safe place, thus constituting much of the 'savings glut'. 
finance industries reconfigured business plans in ways that verged on white-collar gangsterism, using 'sub-prime' mortgages and other misleading marketing techniques to target new customers whose low incomes and dubious credit backgrounds were disregarded. Next, the financial sector purchased and repackaged these mortgages into derivative products (CDOs, collateralized debt obligations) that were structured into tranches that disguised the risks they contained. Then, to hedge their investments, buyers of CDOs purchased CDSs (credit default swaps) from a booming risk-insuring business. The incentives of eased standards, cheap money, and new financial techniques opened the prospect of vast profits and fortunes. Real estate agents and brokers made more by selling more houses, and the construction industry made more by building more houses. The banks and mortgage companies made big money from selling risky mortgages and could then wash their hands of risk and responsibility for their dubious marketing practices by handing off loans immediately to huge financial firms, including the country's largest banks and Wall Street investment houses. Financial firms in turn came to dominate the financial side of the mortgage market, making more fees the more mortgages they could convert into derivatives and sell off, with loyal help from ratings agencies that they hired who provided misleadingly high ratings. Finally, the more CDSs that were contracted to hedge these new derivatives, the more insurance companies profited and grew. The pace became frantic because the quicker things could be sold rather than held as collateral, the greater the profits, leading the financial sector to leverage itself well beyond what was prudent (Fligstein and Shin 2007). Once these processes were set in motion, they compelled everyone - whatever they felt about risk or morality - to follow or lose out (Fligstein and Goldstein 2011).

The most misleading underlying process in the bubble was that as the real estate market grew hotter, house values climbed, leading homeowners to feel wealthier and tempting them to take on ever more debt. When the bubble began bursting in 2006-2007, house values declined. Mortgage holders who were in over their heads were then threatened by foreclosure, and many who had borrowed against their houses went 'underwater', owing more than their houses were worth. Another result was that the questionable value of mortgage-based CDOs led CDS holders to invoke their insurance. It was not long before over-leveraged financial institutions and the vast, unregulated 'shadow banking' system were endangered. The first epochal financial crisis of neoliberal capitalism in the era of globalization was beginning.

The signs of impending doom first appeared in mid-2007, when Bear Stearns hedge funds failed, Citigroup wrote down assets, the UK's Northern 
Rock was bailed out in an emergency government move, two large BNP Paribas hedge funds closed, and Dexia bank in Belgium came under pressure from lenders, stockholders, and ratings agencies. Central Banks - the US Fed, the Bank of England, and the European Central Bank - quickly opened international swap lines to ensure that credit did not freeze. Then, in spring 2008 , the Fed saved Bear Stearns by subsidizing a bargain-basement acquisition by JP Morgan and helped Bank of America acquire Merrill Lynch. There were both political and financial limits to these responses, however. When the US Treasury and Fed failed to find a buyer in September to prevent Lehman Brothers from failing, generalized panic followed. A day later AIG, a huge insurance company loaded with CDS contracts, received $\$ 85$ billion to stay afloat from the same sources. In a few months, the stock market lost more than half of its value and the critically important overnight credit supply of commercial paper froze.

With financial markets in free fall and credit blocked, the 'real economy' stalled, growth stopped, consumption dropped, pensions and savings shrunk, companies went bankrupt, real estate loan operations collapsed when mortgage-holders could not longer pay, unemployment shot up, government revenue streams diminished, and public debt rose as a depressionary spiral began. One result, which might otherwise not have happened, was that Barack Obama was elected. The experts, including Bernanke, the Bush and Obama Treasury teams, and most economists, converged on short-term 'neo-Keynesianism' to limit the damage and stop the downward spiral by huge Fed interventions - several trillions of dollars - to re-open credit markets with newly printed money (Irwin 2013). Massive emergency legislation passed under Bush (the 2008 TARP - Trouble Assets Relief Program) and Obama (the 2009 ARRA - American Recovery and Reinvestment Act). TARP, meant to isolate 'toxic assets', was used instead to bail out banks. ARRA financed stimulus plans to subsidize threatened industries (automobiles, in the first instance) and job-creating public works (Blinder 2013; Burtless and Gordon 2011). The financial 'fire-fighting' did not stop at US borders either. The spread of the crisis from Wall Street and the City of London to other places demonstrated global financial sector interconnections, as did international public policy responses to limit the damage. ${ }^{2}$

2 Internationally, some countries had 'better' crises than others. Canada escaped the worst, despite connections between its large financial sector and Wall Street, because its real estate industry and banks were better regulated. Germany, the Netherlands, Austria, and other Northern Europeans fared better because of superior international competitive and budgetary 
These efforts were largely successful in moderating the Great Recession and stopping the spiral towards depression. Six years after the first signs of crisis, however, the US economy's recovery has been slow, patchy, and unequal. US grow th became negative in the last quarter of 2007, dropped to -4 percent in 2009 but returned to low positive levels in 2010, since then hovering around 2 percent. The recovery has been relatively jobless, however, and unemployment, which had risen from 5 percent in 2008 to 10 percent by the end of 2009, only dropped below 8 percent in 2013, while new claims for unemployment insurance have barely returned to pre-recession levels. 8.5 million jobs were lost, with the construction and manufacturing sectors (and male workers, minorities, the lower skilled, and immigrants) hardest hit. Unemployment episodes have remained very long - a median of 20 weeks since 2008 - and the long-term unemployed face a grim future. One estimate in mid-2013 was that 14.3 percent of the workforce was unemployed, underemployed, or out of the workforce altogether (CBPP 2013: 8). Labor force participation has declined (from $67+$ percent in 2000 to 63.5 percent in 2013). The US's Gini coefficient - a commonly used measure of income inequality - which had been 0.38 in 2008 is now at the 'bad' end of OECD numbers next to Turkey and Mexico (OECD 2012).

Some had hoped that the 'neo-Keynesianism' triggered by the financial crisis would be the start of a new Keynesian era. This was not to be: the bailouts, stimulus plans, and Fed's massive 'quantitative easing' are all nearly over. ${ }^{3}$ The sectarian turn of American Republicans, engaged in political trench warfare about fiscal policy to starve federal government to minimalist dimensions, also ensures that it will not happen anytime in the near future. In addition, despite some regulatory reform, crisis politics has re-installed Wall Street and 'too big to fail' banks back at the core of the American economy in hypertrophied form, explainable by the need to re-stabilize the American financial system rapidly and by the political influence of the financial sector. The status quo ante has been restored, at the cost of an estimated 14+ trillion US dollars (Atkinson et al. 2013)!

Which, if any, American groups might have been tempted to protest because of the crisis? The most visible mobilization came from the radical

situations and because of their labor market flexibility. Poland was the only European country to avoid a recession.

3 Marc Blyth, in his brilliant essay on austerity in economic theory, ironically labels the European version of this 'twelve month' Keynesianism (Blyth 2013). 
populist right, embodied in the Tea Party. ${ }^{4}$ The Tea Party emerged primarily from the South and the Middle West, where American populism has been recurrent historically. The south has been anti-Washington and against the Eastern elite since the Civil War, usually on racist grounds, and its indignation was rekindled by the Democratic Party's promotion of civil rights laws in the 1960s and 1970s. The Middle West has been de-industrialized by technological change and globalization, which decimated its large industries and diminished 'middle class' unionized manufacturing work. In both regions, Washington's neo-Keynesian responses to crisis were received as statist mistakes produced by corrupt collusion between politicians, experts from the Eastern elite, big financial interests, and the mega-rich. Tea Party mobilization quickly found a home inside the Republican Party, explainable by the ways in which crisis issues meshed with older, hard-right Republican frames of religious and moral fundamentalism, anti-statism, and opposition to social transfers to racial minorities, immigrants, and youth. Financial support for the movement has also flowed from wealthy American right-wingers taking advantage of the recent liberalization in campaign finance law and seeking to manipulate the Republican Party further rightwards. The Tea Party example may suggest that the important far-right movements find it easier to move into 'conventional' party politics than 'progressive' mobilizations. A similar movement from protest mobilization to party form is found all across Europe, strongly fed by antiimmigrant xenophobia, the effects of the crisis, and burgeoning hostility to the European Union.

This volume is interested primarily in left-leaning 'progressive' movements. They have been omnipresent throughout US history, in fact, and particularly significant since the protest cycle beginning in the civil rights and anti-Vietnam war movements in the 1960 s. Such movements have often taken on the forms of decentralized, rank-and-file mobilizations that once they are well-organized around specific 'social justice' issues - tend to lobby parties indirectly rather than taking on party form, particularly because the majoritarian US system makes it difficult for 'third parties' to succeed. Many such mobilizing and lobbying strategies have actually succeeded to a degree, despite the recent rightward movement in American politics. Equality-related matters have been the stock-in-trade of most of these 'progressive' movements, even if the concept of equality has been redefined away from older focuses on class-economic inequality. Older frames returned, however, taken up by movements, left-wing intellectuals, 
and progressive publications after the crisis hit. The Occupy movements, coined by a non-profit, anti-consumerist Canadian organization and partly inspired by the Arab spring and European protests, provides the best example.

Later chapters in this volume will explore the connections between movements like Occupy Wall Street and social groups hurt by crisis. Canvassing some possibilities may help, however. Income stagnation in the US, excepting vast increases for the top 1 percent (and a small fraction even of this group), the decline of 'middle class' manufacturing jobs, and growing employment insecurity have been salient issues for some time in the United States. Such changes have recently taken on specific forms for youth. Upward mobility through higher education, the ideal life course in recent interpretations of the American Dream, is no longer what it once may have been (Corak 2012). Finding good jobs for non-technically-specialized university graduates had become harder for some time. The wage premium going to university graduates still exists but in diminished forms, and education costs, especially for private universities, have skyrocketed along with student debt. The crisis considerably strengthened these processes. Entering the labor market has become much more difficult, obliging many to accept work beneath their expectations and straining families. 'Young people' have always been likely protesters, but crisis circumstances - with US youth unemployment twice the national average - have made the likelihood greater.

More broadly, persistent unemployment, underemployment, and unemployment-induced long-term labor market exits have touched millions. The decline in American trade unionism over recent decades membership, at 11 percent, is one-third what it was in the 1970s - caused by globalization, technological change, labor market dualization, and neoliberal anti-union crusades may help explain the relative paucity of strikes, labor demonstrations, and strong political lobbying around employment issues in the US. On another level, millions have lost their homes to foreclosures, which have risen to 6-7 times their pre-crisis level (roughly 3 million annually), in ways that also disproportionately hurt minorities. This may have fueled deep resentment against banks and pre-crisis housing market shenanigans, but private debt and bankruptcy issues in American culture tend to become more a matter of individual shame than a spark to collective protest. Finally, US opinion polls point to serious problems of political legitimacy. Very few Americans believe that the US Congress is functional, for example, let alone responsive to citizen needs. Manichaean partisan conflict, in which both parties seek 
possible electoral support with huge energy and resources, may mean that crisis-generated anger finds its way more quickly into conventional politics than into protest (Kenworthy and Owens 2011).

\section{Contagion: The Eurozone Crisis}

Europeans first hoped to escape the crisis because they were better regulated and armed with more automatic stabilizers than the US. The collapse of the global financial sector in 2008 obliged Europe to acknowledge the spread of dubious American financial practices to their banking systems, however. The first responses to the crisis went smoothly. The European Central Bank (ECB) provided liquidity to keep credit flowing and closely coordinated its actions with other central banks (Trichet 2010; Quaglia et al. 2009: 74-75), while EU member states agreed to common policy objectives (Bastasin 2012). National authorities in the EU retained most fiscal prerogatives, implying ad hoc coordination to general objectives rather than common EU policies (Bastasin 2012; Quaglia et al. 2009: 76-77; European Commission 2009). Bailouts came first, with banks sometimes recapitalized or semi-nationalized; deposits were guaranteed; and private banks consolidated and merged. ${ }^{5}$ Then came stimulus packages, again organized around coordinated general objectives and different national paths, which, together with automatic stabilizers, amounted to between 3.3 and 4 percent of EU GDP, with special plans for newer central and eastern European members. ${ }^{6}$ Financial sector regulatory reform was urgent, and a 'High Level Group on financial supervision' recommended imposing higher capital requirements, reforming credit-rating agencies, and introducing new asset valuation and accounting techniques. The High Level Group also concluded that those parts of the financial system with systemic importance needed new regulation and supervision plus core regulatory

5 Coordination went beyond the EU's borders. The G-7 rapidly convened the G-20, enlarging discussions beyond the rich North. The November 2008 G2o meeting in Washington concluded that members should use fiscal stimulation to avoid collapse and initiated an avalanche of good international intentions replicating both US and EU outlooks.

6 New EU members faced projections of a 15.8 per cent GDP decline through 2009 (Darvas 2009), despite great differences and varying national responses. Poland, the Czech Republic, Slovakia, and Slovenia weathered the initial storm well; less developed Baltic and Balkan countries had larger deficits and debts; and Hungary faced bankruptcy and needed IMF help. Many CEECs also had dangerous Euro-denominated, EU-15-originated consumer debts (often mortgages), necessitating special public-private deals. Different exchange rate regimes created different dilemmas. 
and supervisory standards within a new EU crisis management framework (Pisani-Ferry and Sapir 2009; Véron 2010).

These responses helped to stem financial sector collapse and to limit real economy damage (Ross 2011). But a much larger drama for the EU's Economic and Monetary Union (the Euro and its institutions) began in later 2009 after a new government announced that Greek statistics had been manipulated and that Greece's budget deficit was higher than anyone had suspected. The bond markets, sensing that Greece might default, then raised interest rate spreads between Greece and Germany. International credit rating agencies downgraded Greece. Greece was the poster child for exploiting the flaws in Eurozone economic governance. EMU's one-size-fits-all interest rates provided a windfall to poorer EMU countries and had also allowed them to gain much easier access to transnational capital flows, encouraging Greece and others to grow by overborrowing (Fernandez-Villaverde and Santos 2013; Aglietta and Brand 2013; Blyth 2013). The EU's responses to the crisis after 2007-08 then contributed to larger national deficits and debts, and crisis-changed economic conditions began to lower growth and government revenues while also pushing up government spending (Mitsopolous and Pelagadis 2012; Jones 2012). ${ }^{7}$ The main EMU rules from the 1993 Maastricht Treaty - the 3 percent annual deficit and 60 percent cumulated debt ceiling - were arbitrary, narrowly focused on public debt, and pro-cyclical, and the treaty itself had provided few effective mechanisms for enforcing them (Eichengreen 2012). In addition, there were few emergency provisions, no plans for a country to default and leave, and the treaty ruled out financial solidarity among EMU members.

\section{Institutions Make Policies!}

First responders in the American crisis included a strong central government, a single national jurisdiction, and a powerful central bank with flexible mandates. EMU, in stark contrast, was a single currency without a central government, with multiple national jurisdictions, and a European Central Bank (ECB) with a legal mandate restricted to fighting inflation. The result was that the Eurozone's crisis responses had to be negotiated among many countries and decisions had to be made in either the Eurogroup (the leaders of EMU member states) or the European Council (national

7 Responsibilities also lay with the Euro-zone's richer members who had profited from EMU's perverse incentives by exporting goods and capital to poorer countries in ways that increased divergence within the Euro-zone (Dullien and Schwartzer 2009; Eichengreen 2010, 2012). 
leaders of the broader EU), both intergovernmental. ${ }^{8}$ Past experience with intergovernmental processes indicated that they took a significant amount of time, let to incremental decision-making, and often produced suboptimal compromises. The differences in size and economic power between EMU countries meant in addition that decisions would probably be biased towards the preferences of the most powerful members. It followed that the institutional arrangements for responding to a crisis could matter as much as actual policies themselves.

It took six months for new Eurozone policies to begin to be decided, allowing crisis contagion towards Ireland (which had a worse housing-banking bubble than the US) and Portugal (whose debt issues flowed from its relative poverty). Eurozone leaders, faced with threats from the stock market, finally agreed in May 2010 to set up a temporary $€_{750}$ billion European Financial Stability Facility (EFSF) that would provide conditional loans to menaced Eurozone countries at 'non-concessional' interest rates that would quickly prove to be too high. ${ }^{9}$ The Greek government then signed a 'memorandum of understanding' (MOU) to borrow $€$ 11o billion. The MOU, tailored to specific national conditions, as were those that later engaged Ireland, Portugal, and Cyprus, involved tough quarterly reviews by the European Commission, the ECB, and the IMF (known as the Troika). The terms of Greece's firstquarter MOU (through June 2010) obliged the Greeks to begin reducing their deficit to 3 percent by 2014 (an utterly unrealistic demand), cap public sector pay for three years, reduce the public sector wage bill, eliminate public sector bonuses, increase VAT and other taxes, reduce high pensions, eliminate pension bonuses, freeze all pensions, reform the labor market by decentralizing negotiations, reduce public investment, undertake tax reforms, reform bank governance, rebuild local administration, enhance competition by installing a new competition authority and breaking the power of a wide range of private professional monopolies, make it easier to

8 As in any EU crisis - and this was the greatest in EU history - there were secondary actors. The bond markets, whose eruptions pushed bargaining forward, were the most important. The supranational ECB stretched its legal mandate to limit the crisis and influence member responses. The European Commission was present mainly because it alone could propose legislation following the European Council's strategic leadership, and because of its administrative charges. Finally, the IMF helped provide and structure bailout loans.

9 The Commission proposed loans without the IMF, and France suggested European bonds. IMF participation was opposed by the ECB and Commission, but Germany insisted on its presence, believing that IMF conditionality would strengthen pressure on Greece to change and that IMF loans would lower fire-fighting costs (Bastasin 158). Merkel opposed 'Eurobonds' out of moral hazard fears and worries about Germany's credit rating, plus anticipation that the German Constitutional Court would find them unconstitutional. 
start businesses, and more (European Commission 2010). The conditions, which were parsed in three-month assignments until the end of the loan period, threatened a huge number of Greek social groups. Many of these received the conditions as invitations to protest, which they then did, in manifold ways. MOUs for other EMU members that later had to take loans were similarly harsh, similarly monitored, and also led to protest.

Lying behind Eurozone hesitations were differences between Germany and France, the leaders of EMU (Marsh 2010; Dyson 2013; Krotz and Schild 2013). The French, worried about EMU banks, wanted more 'economic government' and a quick Greek bailout. Germany's initial response was that Greeks had caused their own problems and should fix them themselves. Germany, far more powerful economically, maintained its ordoliberal economic orthodoxies, but its reunification had opened space for German leaders to assert themselves. ${ }^{10}$ This led to the resolve not to serve as EU checkwriter of last resort, removing the classic EU solution of German-subsidized bailouts from the table. Shorter-term domestic politics, public opinion, and German Chancellor Angela Merkel's thinking supported this course (ECFR 2011; Gros and Roth 2011). The French were much weaker because the French economy was vulnerable. An imminent presidential election, which Sarkozy would lose in 2012, led him to posture about co-leadership (causing the term 'Merkozy' to be coined) for domestic consumption rather than challenging German power. The Germans and Merkel would thereafter shape most crisis responses.

The May 2010 decision revealed new German flexibility. If EMU was to continue, flaws in Maastricht's EMU architecture had to be fixed (Aglietta and Brand 2013). An annual 'European Semester' was thus inaugurated in which member states submitted budget plans for peer scrutiny before budgets were voted. There were also a 'six pack' and 'two pack' of directives and regulations for stronger and more sophisticated monitoring of national fiscal policies plus new, more automatic sanctions for bad behavior. New monitoring procedures and financial sector regulation were based on the 2010 Delarosière committee report (Batastin 2012; Jouyet 2012). There were problems obtaining financial backing for most of these reforms, however, usually because Germany sought to limit its exposure. Germany, backed by France, also urged new 'treaties'

10 Ordo-liberalism structured the successful reconstruction of the post-war German economy. At its center were constitutional rules for a 'social market economy' that involved collaboration among producer groups and social programs. A politically independent Bundesbank devoted to price stability had the power to compel private and civil society actors to moderate egoistic interests. Ordo-liberalism provided the matrix for both the Maastricht EMU bargain and the 1997 Stability and Growth Pact (see Blyth 2013: 138-147). 
by coalitions of the willing. A 2011 'Euro Plus Pact', signed by all Eurozone countries plus eight other EU members, pledged controls on wage growth, raising retirement ages, reducing payroll taxes on labor, and new EU debt and deficit rules with stiff penalties for non-compliance. The 2012 'Treaty on Stability, Coordination and Governance' obliged signatories to commit to balancing their national budgets (Fitoussi 2013). More recent reforms that have emerged include the commitment to a 'Banking Union' to establish ECB supervision over EMU banks, a new European 'resolution' authority to restructure or close failing banks, and an EMU deposit insurance system.

Decisions were repeatedly sold to the public as far-seeing solutions to crisis but often included genuine mistakes that made things worse. The interest rates of the original 2010 Greek bailout were too high and repayment schedules too rapid, worsening Greece's debt problems, upsetting bond markets, and hastening a second Greek loan in 2012. ${ }^{11}$ Next, while preparing the October 2010 European Council, Germany proposed 'private sector participation' (i.e. making bondholders pay their share in bailouts), which deeply upset the ECB and produced new market agitation (Bastasin 2012). Later in 2011, discussions about the second Greek loan, including haircuts, went on for months, upsetting bond markets again and precipitating contagion to Italy and Spain (Financial Times 2011a, 2011b, 2011c; Boone and Johnson 2011). The October 2011 European Council sought to calm things with empty promises, causing renewed market agitation. It took more ECB 'non-standard' actions (quantitative easing) and Mario Draghi's 2012 public promise to 'do what it takes' plus a calming in global markets to keep things under control (Dyson 2013: 211-218). ${ }^{12}$ In November 2011, 'Merkozy' engineered the back-to-back removal of first Greek Prime Minister George Papandreou (who had proposed a referendum on the second Greek loan)

11 These judgments are underlined in an extraordinary IMF internal review that followed an earlier IMF re-evaluation of the austerity multiplier effects of Euro-zone loans. The report, a useful overview of the first Greek loan, strongly criticized the workings of the Troika (IMF,

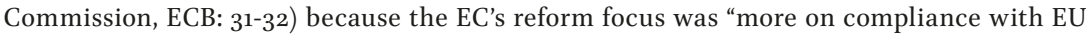
norms than on growth impact [... and ...] was not able to contribute much to identifying growth enhancing structural reforms" (p.31).

12 Despite repeated German criticism, the ECB used 'non-standard' methods of buying members' national debt instruments from bond markets and injecting new, low-interest-rate liquidity into Euro-zone economies, partly in the hope that member states would devise more effective sanctions for bad fiscal behavior. Beginning in 2010, the ECB also lowered collateral requirements to purchase the bonds of those EMU members that were hardest hit (the Securities Markets Programme) and in 2011 started low-interest loaning to banks in 'long-term financing operations' (LTROs) and in 2012 'Outright Monetary Transactions' (OMT - market purchases of bonds from member states that had requested EFSF/ESM aid). 
and then Italian Premier Silvio Berlusconi (who was stalling on promised reforms). They were both replaced by 'technocrats' with deep Brussels connections. This did little to help Greece and Italy economically but further angered Greek and Italian citizens. Then in 2013, EU leaders made another bad move: in bailing out Cyprus, they called for deep haircuts that would have decimated small depositors before market threats caused them to beat a hasty retreat (Rachman 2013; Wolf 2013). Finally, hesitations about moving to a banking union in 2012-2013 - again because of German unhappiness at Eurozone collective risk-sharing - unsettled the situation once more.

\section{Policies and Pain}

Repeated crisis policy choices consistently imposed the views of other EMU governments, particularly Germany, on countries in need of help. It has been the actual crisis fire-fighting policies that have hurt the most, however. To avoid bankruptcy, four endangered Eurozone members - Greece, Ireland, Portugal, and Cyprus - had to accept conditional loans that looked an awful lot like IMF Structural Adjustment Programs, while the banking systems of two more countries - Spain and Italy - were kept afloat by loans, bearing their own conditions, from the ECB. Borrowers were kept to a draconian schedule for reducing debts and deficits, cutting back extensive budgetary and social programs, decentralizing the labor market, reducing public employment, and privatizing government-owned property and businesses. Such policies combined a German ordoliberal backbone with Europeanized Anglo-American neoliberalism from the Commission's economics directorate, and, in the case of sovereign debt, traditional IMF loan rules. The economic mantra behind these approaches was that a rapidly applied, harsh dose of austerity would lower unit labor costs, abolish rent-seeking, and establish starting points for virtuous growth. Beyond this 'austerianism', reforms to EMU's architecture brought new invasions into national economic policy sovereignty through technocratic mechanisms lodged in the European Commission that lacked clear democratic mandates.

The consequences have been dramatic. There has been negative economic growth since 2008 in the Eurozone as a whole, as seen in Chart 2.1. The worst of this was in the Great Recession period, with a brief recovery until 2011-12, and then a second recessionary dip until late 2013, followed by a slight uptick.

Growth in those Eurozone countries that were the objects of conditional loans and obliged to undergo 'internal devaluations' has been much worse, however. With the beginning of 2008 as a starting point, Greek GDP declined 
Chart 2.1 Euro Area (18) GDP Growth Rate

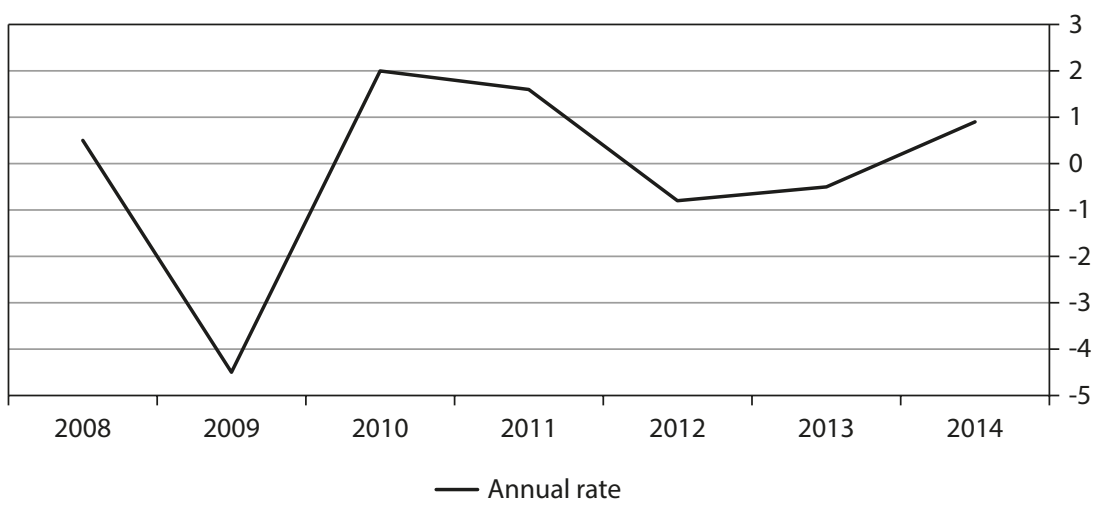

Source: Eurostat - code: tec00115 (27 March 2105)

by 4 percent in the Great Recession, but then dropped to a low of -9 percent in 2011, the low point of its crisis, before it slowly climbed to -2.5 percent in early 2014. The Irish economy performed somewhat better, dropping to -7.8 percent at its low point in 2009-10, then slowly recovering to +2 percent by 2012 before dropping back into recession and then recovering in 2013-2014. Portugal dropped to -4 percent in 2009 , then grew by +1.8 percent in 2010 , dropping back to -4 percent in 2013 before moving into positive territory recently. Spain and Italy, whose banks were helped out by the ECB, did better but still suffered much lost growth.

Unemployment across the Eurozone shot up in the crisis and remains very high, as Chart 2.2 shows.

The hardest-hit Eurozone crisis countries vary on the unemployment front. None have done well, but economic differences have created different employment profiles. Greek unemployment rose steadily from 6 percent to 28 percent from 2008 to the beginning of 2014 . Ireland was at 4 percent in 2008 and is now at 12 percent. Portugal began at 7.6 percent, rose to 17.7 percent in early 2013 and dropped to 15.3 percent in 2014. Spain was at 9.6 percent in 2008 and was nearly at 27 percent in 2013 . Italy rose slightly from 9 to $12+$ percent in 2013, the Eurozone average.

Youth unemployment is particularly significant if, as we suspect, young people are more protest-prone than their elders. The numbers in Chart 2.3 are striking enough for the Euro-zone as a whole, and much worse for the countries hardest hit by the crisis.

These numbers do not take into account young people who are otherwise out of the labor force for non-labor market reasons, but they obviously 
Chart 2.2 Euro Area (18) Unemployment Rate

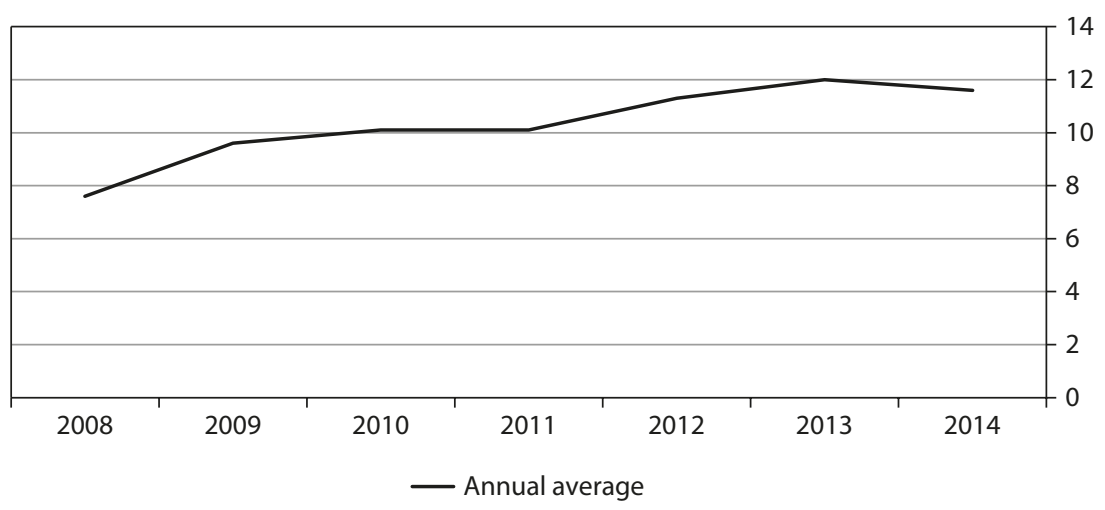

Source: Eurostat - code: une_rt_a (27 March 2015)

Chart 2.3 Euro Area (18) Youth Unemployment Rate (under 25)

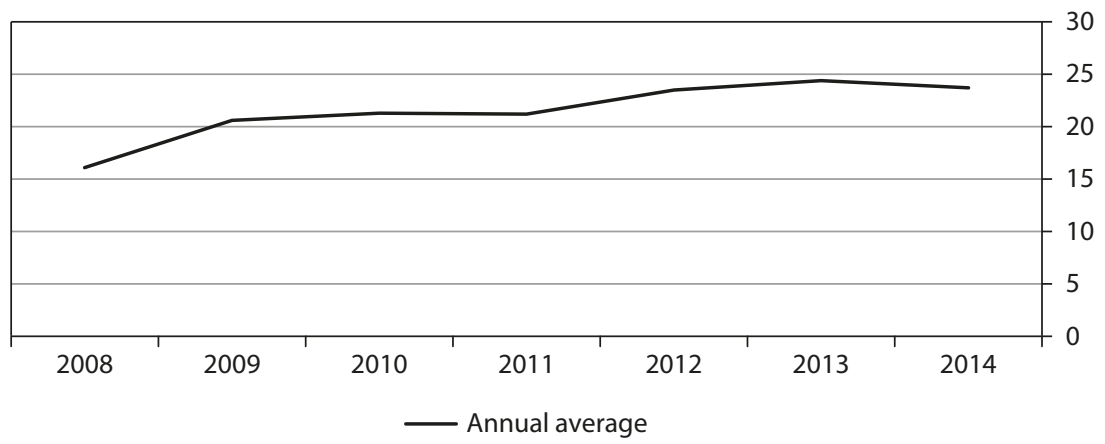

Source: Eurostat - code: une_rt_a (27 March 2015)

show youth unemployment rapidly rising. For the most part, the Eurozone crisis countries are well above the general Euro area. From 2008 to early 2014, Greece's youth unemployment rose from 21 percent to 60 percent; Ireland's from 10 percent to 25 percent; Portugal's from 20 percent to 36 percent; Spain's from 20 percent to $5^{8}$ percent; and Italy's from 21 percent to 47 percent.

Reducing long-term unemployment had been one of the most important goals of the European Union. The Eurozone crisis wiped out any progress made in this area, however, as Chart 2.4 shows.

'Internal devaluations' leave citizens of poorer EMU countries in conditions of austerity that will persist for years. New growth, even where it 
Chart 2.4 Euro Area (18) Long-term Unemployment Rate (12 months and more)

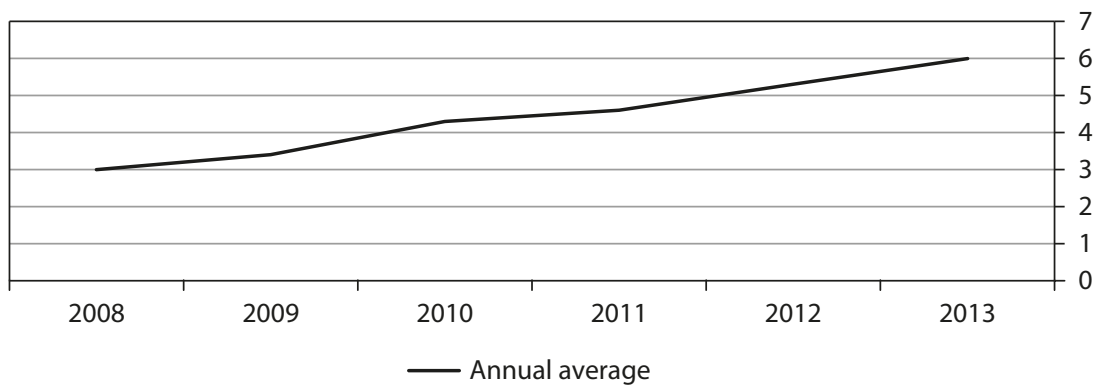

Source: Eurostat - code: tsdsc330 (27 March 2015)

exists, is low and relatively jobless. Even the best-educated young people in stricken countries, and some other European places, face grim employment prospects, placing new strains on their families, delaying entry into the labor force, and leaving those affected in life-course limbo. Poverty and social exclusion have shot up, especially in these most afflicted countries (Eurostat 2014; EU Commission 2013a, 2013b). Migration to better-off EU countries is possible, and there is some evidence that it has grown, especially among the young, but mobility within the EU has always been limited by the difficulty of coping with another culture, language, and place where better jobs are reserved for the locals. Those who stay face rising long-term unemployment as technologies and work processes change rapidly, implying permanent exits from the labor force, new poverty, and individual and family disaster. Social science knows much too little about how much and what kind of social cohesion is needed to keep developed societies from fraying, but these numbers - and others we might have highlighted - imply future problems. As we have earlier noted, there has been a punitive 'cold shower' logic to economic governance throughout the EU crisis. Countries in deep trouble, as well as others with precarious economic situations that have yet to make themselves dependent on outside help, are now told (and often constrained) to stand under cold water long enough to rid themselves of the results of their alleged bad economic habits. Those who prescribe the cold showers assert that only then will these countries be able to begin climbing upwards economically. The 'cold shower' approach is a bet against a very uncertain future. Many think that it is unlikely to pay off, or at least not in the ways that 'austerians' claim that it will. One way or the other, there will be a significant number of European citizens standing under cold water for some time to come. 
Polling has shown how many of these citizens have come to understand all this. The crisis has worsened the EU's chronic legitimacy problems in ways threatening to the EU. Eurobarometer surveys show favorable opinions of the EU rapidly declining, with these trends stronger in the southern member states. Pessimism about the future is widespread, again more pronounced in those countries more affected by the crisis, where doubts about the EU's anticrisis policies are profound (Debomy 2013; Walton and Zielonka 2013). The Pew Global Survey conducted in the spring of 2013 reported declining support for the European project - only 28 percent believe that European integration has helped their economies, with the loss of confidence particularly strong among younger people (Pew Research 2013). If we reflect on the recent shift of farright European parties toward supplementing anti-immigrant xenophobia with anti-EU nationalism, as well as the trend of harder-left parties that have emerged to the left of social democrats advocating a return to closed-border statism and embracing Euroskepticism, it is clear that the EU has become a veritable target of protest. Indeed, Euroskeptical attitudes and political currents have rapidly spread almost everywhere (Torreblanca et al. 2013).

These surveys correlate with election results. Since the beginning of the crisis, European voters have repeatedly removed the incumbent governments that had presided over crisis responses (excepting Germany). In Ireland, Fianna Fail electoral domination, which had seemed eternal, has ended - one consequence of a terribly mishandled and corrupt housing bubble, itself the product of American-style public policy mismanagement. Social democratic governments in Portugal, Spain (where the central issue has been another housing bubble created by bad public policy and banking cupidity), and Greece have all been replaced by right-wing regimes that themselves rapidly became precarious. The severe electoral defeats of Latin European social democracy - with France a possible future addition in the near future - has great significance. European social democratic parties, for a century the political hope for many on the left, have been slowly losing electoral support in recent years (Moschonas 2011). They can still win elections and lead governing coalitions, but their voting numbers - and, more significantly, credibility as carriers of popular grievances - have been declining. Europe's south had been a particularly bright spot for social democracy because political parties there had been able to harness the promises of modernization from joining the EU. The Eurozone crisis may have ended this. ${ }^{13}$

13 There are deeper issues. Center-left parties have turned into electoral machines staffed by political professionals and policy wonks whose most important task is now to govern 
The results of the 2013 Italian elections after the EU-imposed Monti-technocratic government's time expired went well beyond firing incumbents. In a campaign saturated by EU and Eurozone issues, nearly 25 percent of the vote went to the Five Star Movement (35 percent of those between the ages of 18 and 34), a party led by a professional entertainer whose appeal was a refusal to play the Italian political game in traditional ways. At about the same moment, Greek elections saw Pasok decimated, the center-right returned to power, and Syriza - a left party whose indignation was clearer than its policy proposals - doing better than anyone else, sinning, in fact, in January 2015. In general, anti-establishment protest parties on the left and the right have prospered in the crisis, including openly fascist extremists in Greece. In France, a country that has avoided the worst but has teetered on the edge of serious economic problems, Nicolas Sarkozy lost to socialist François Hollande in 2012, and within a year Hollande had acquired the lowest popularity ratings in the history of the Fifth Republic. ${ }^{14}$

Other crisis results include accentuated divisions between the Eurozone's north and south. Northerners, arrayed around Germany, have been the main contributors to bailouts and have insisted most forcefully on the 'cold shower' line for the stricken southerners who had hoped for greater solidarity and flexibility. On some occasions, particularly during election campaigns, this has translated into quasi-ethnic attacks directed at Germany. Prior to the crisis, EU southerners had been among the most positively 'European' member states, but many of them have since changed their minds. The crisis has also deepened the division between EMU 'ins' and 'outs', nourished Eurosceptics in the UK and other places, and laid foundations for an ever more complex and 'geometrically variable' EU.

\section{Storms Past, Storms Still to Come?}

The US crisis brought huge social costs, but the American context made it particularly difficult to anticipate protest beyond hard-right movements

market capitalist societies in a threatening Europeanized and globalized world. Their offers and concessions to progressive electoral constituencies can be real but limited by this priority. Many potential progressives, including protesters, may vote for them in the absence of alternatives, but social democrats are seen as reliable vehicles for the kinds of changes that are needed.

14 If one extended the list beyond the countries directly targeted by crisis but where incumbents were tossed out by the crisis, it would also include the UK, Belgium, the Netherlands, and Denmark, with more to come. 
like the Tea Party and the progressive 2011-2012 Occupy movement. American crisis policies were more direct and effective than those in Europe, despite the US' blocked federalism, because of its strong central bank and determined political elites who possessed the leverage to initiate anticrisis policies, its single national jurisdiction and favorable international financial position. Recovery has been slow, however, and it remains to be seen whether this will stabilize a situation in which the 'middle class' is being hollowed out and an unchastened financial sector is re-installed in its luxurious Wall Street lodgings. Widespread suffering has drawn new attention to growing inequality, declining social mobility, rudimentary social policies, and the weakness of traditional protective organizations such as trade unions. Protest is a time-honored American reflex, but it coexists with a great reliance on individual resilience. US protests may or may not be aligned with major national partisan conflicts or with huge American lobbies, but one cannot help underlining that the US has been riven for decades by partisan mobilization about fundamental social choices between a neoliberal and culturally conservative new Republicanism and a defensive 'liberalism' around the Democrats. This great divide will continue to play an important role in shaping the form that protests take in the US and whether or not it corresponds to 'conventional' American politics.

Europe is different. Salvaging the Eurozone has involved clumsy intergovernmental decision-making that has led to an imposition of harsh policies by some on others. Indignados or Occupy-style 'progressive' protests have been important to varying degrees, particularly in 2011-2012, throughout crisis-stricken countries, even if the Arab Spring movement that inspired and, to a degree, guided these movements, has not always turned out happily. Analogous movements recur, as in Ukraine, and may help keep strategic and tactical memories fresh. Other types of protest have also occurred, including official and unofficial strikes, repeated student protests about educational policies and budgets, and strident mobilizations by specific threatened interests. Resentment levels among those hurt most by the crisis remain high. And beyond any debates about EMU and the EU, national governments, with a few exceptions, seem progressively less able to provide plausible policy solutions to citizens' problems. It is possible that Europe may be in the midst of a massive crisis of politics in which citizens lose their sense that existing democratic processes can produce the desired results. To the degree to which these things are true, stormy weather - including a great deal of new protest - may lie ahead. 


\section{Bibliography}

Aglietta Michel, Brand Thomas. 2013. Un NEW DEAL pour l'Europe. Paris: Odile Jacob.

Atkinson Tyler et al. 2013. 'How Bad Was It? The Costs and Consequences of the 2007-2009 Financial Crisis', Staff Paper 2o, Dallas: Federal Bank of Dallas.

Bastasin Carlo. 2012. Saving Europe: How National Politics Nearly Destroyed the Euro. Washington: Brookings.

Blinder Alan. 2013. After the Music Stopped: The Financial Crisis. New York: Penguin.

Blyth Marc. 2013. Austerity: The History of a Dangerous Idea. New York: Oxford University Press.

Boone Peter, Johnson Simon. 2011. 'Europe on the Brink,' Washington: Peterson Institute for International Economics Policy Brief.

Burtless Gary, Gordon Tracy. 2011. 'The Federal Stimulus Programs and Their Effects', in Grusky D. et al. (eds.). The Great Recession, New York: Russell Sage, 241-293.

CBPP (Center for Budget and Policy Priorities). 2011. 'Chart Book: The Legacy of the Great Recession' (update July 9, 2013) Retrieved 20 May 2014 from http://www.cbpp.org/cms/index. $\mathrm{cfm} ? \mathrm{fa}=\mathrm{view} \& \mathrm{id}=3252$.

Chinn Menzie D., Frieden Jeff A. 2011. Lost Decades. New York: Norton.

Corak Miles. 2012. 'How to Slide Down the "Great Gatsby Curve", Inequality, Life Chances, and Public Policy in the United States', Washington: Center for American Progress. Retrieved 20 May 2014 from http://www.americanprogress.org/issues/economy/report/2012/12/05/46851/ how-to-slide-down-the-great-gatsby-curve/.

Darvas Zolt. 2009. 'The EU's Role in Supporting Crisis-Hit Countries in Central and Eastern Europe', Brussels: Bruegel Policy Contribution.

Debomy Daniel. 2013. 'L'UE Non, L'EURO Oui! Les opinions publiques européennes face à la crise (2007-2012)', Paris: Notre Europe-Institut Jacques Delors.

Dullien Sebastien, Schwartzer Daniela. 2009. 'The EMU Needs a Stability Pact for Intra-Regional Current Account Imbalances', SWP Comments, Berlin: SWP.

Dyson Kenneth 2013. 'Sworn to Grim Necessity? Imperfections of European Economic Governance, Normative Political Theory, and Supreme Emergency', Journal of European Integration, $35(3): 207-222$.

ECFR (European Council on Foreign Relations). 2011. What Does Germany Think About Europe? London: ECFR.

Eichengreen Barry. 2010. 'Imbalances in the Euro-Area', Berkeley: unpublished paper. Retrieved May 20, 2014 from http://elsa.berkeley.edu/ eichengr/Imbalances_Euro_Area_5-23-11.pdf.

- 2012. 'European Monetary Integration with Benefit of Hindsight', Journal of Common Market Studies, 50: 123-136.

European Commission. 2009. 'Economic Crisis in Europe: Causes, Consequences and Responses', European Economy 7 , Brussels: EC.

-. 2010. European Economy: The Economic Adjustment Program for Greece: Occasional Papers 61, Brussels: EU.

-. 2013a. Employment and Social Developments in Europe 2012. Brussels: EU.

-. 2013b. Social protection budgets in the crisis in the EU. Brussels: EU.

Eurostat. 2014. 'People at risk of poverty or social exclusion'. Retrieved 20 May 2014 from http:// epp.eurostat.ec.europa.eu/statistics_explained/index.php/People_at_risk_of_poverty_or_ social_exclusion.

Fernandez-Villaverde Luis Garicano, Santos Tano. 2013. 'Political Credit Cycles: The Case of the Euro Zone', NBER Working Paper 18899, Cambridge: National Bureau of Economic Research. 
Financial Times. 2011a. 'Dogmatists raise the costs of the Eurozone crisis', 16 May.

-. 2011b. 'Eurozone: Frankfurt's Dilemma', 24 May.

-. 2011c. 'Europe: Four steps to fiscal union', 11 August.

Fitoussi Jean-Pierre. 2013. Le Théorème du lampadaire. Paris: Editions Les Liens qui Libèrent.

Fligstein Neil, Goldstein Adam. 2011. 'The Roots of the Great Recession' in Grusky D. et al. (eds.), The Great Recession. New York: Russell Sage, 21-56.

Fligstein Neil, Shin Taekjin. 2007. 'Shareholder Value and the Transformation of the U.S. Economy', Sociological Forum, 22 (44): 399-424.

Gros Daniel, Roth Felix. 2011. 'Do the Germans Support the Euro?', Working Paper No. 359, Brussels: Centre for European Policy Studies.

Irwin Neil. 2013. The Alchemists: Three Central Bankers and the World on Fire. New York: Penguin. Jones Erik. 2012. 'Getting to Greece: Uncertainty, Misfortune, and the Origins of Political Disorder', European Political Science, 12 (35): 294-304.

Jouyet Jean-Pierre. 2012. 'For a Political View of Financial Regulation', in Fondation Robert Schuman, Schuman Report on Europe: State of the Union 2012. Paris, Berlin: Springer Verlag. Kenworthy Lane, Owens Lindsay. 2011. 'The Surprisingly Weak Effect of Recessions on Public Opinion', in Grusky David. et al. (eds.), The Great Recession. New York: Russell Sage.

Krotz Ulrich, Schild Joachim. 2013. Shaping Europe:France, Germany, and Embedded Bilateralism from the Elysée Treaty to Twenty-First Century Politics. Oxford: Oxford University Press.

Marsh David. 2010. The Euro: The Politics of the New Global Currency. New Haven: Yale University Press.

Mitsopolous Michale, Pelagidis Theordore. 2012. Understanding the Crisis in Greece. Harmsmills, Basingstoke: Palgrave Macmillan.

Moschonas Gerassimos. 2011. 'Historical Decline or Change of Scale?: The Electoral Dynamics of European Social Democratic Parties, 1950-2009', in Cronin James E. et al., What's Left of the Left? Democrats and Social Democrats in Challenging Times. Durham: Duke University Press, 50-85.

OECD. 2012. 'OECD Economic Surveys UNITED STATES', Paris: OECD.

Panitch Leo, Gindin Sam. 2012. The Making of Global Capitalism: The Political Economy of American Empire. London: Verso.

Pettis Michael. 2012. The Great Rebalancing: Trade, Conflict, and the Perlious Road Ahead for the World Economy. Princeton: Princeton University Press.

Pew Research. 2013. The New Sick Man of Europe: the European Union. New York: Pew Research Center.

Pisani-Ferry Jean, Sapir André. 2007. Banking Crisis Management in the EU: An Interim Assessment, Working Paper 2009/o7, Brussels: Bruegel.

Quaglia Lucia et al. 2009. 'The Financial Turmoil and EU Policy Co-operation in 2008', in Copsey N., Haughton T. (eds.), The JCMS Annual Review of the European Union in 2008. Oxford: WileyBlackwell, $63-88$.

Rachman Gideon. 2013. 'Europe's leaders run out of credit in Cyprus', Financial Times, 1 March. Ross George. 2011. The European Union and its Crises: Through the eyes of the Brussels elite. Houndsworth: Palgrave Macmillan.

Streeck Wolfgang. 2011. 'The Crises of Democratic Capitalism', New Left Review, 71: 5-29, September-October.

Torreblanca Jose Ignacio. et al. 2013. The Continent-Wide Rise ofEuroscepticism. Berlin:European Council on Foreign Relations. 
Trichet Jean-Claude. 2010. 'State of the Union: The Financial Crisis and the ECB's Response, 2007-2009', in Copsey N., Haughton T. (eds.), The JCMS Annual Review of the European Union in 2009. Oxford: Wiley-Blackwell, 7-19.

Véron Nicolas. 2010. 'An Update on EU Financial Reforms', in Policy Brief PB 10-30. Washington: Peterson Institute for International Economics.

Walton Nicholas, Zielonka Jan. 2013. The New Political Geography of Europe. Berlin: European Council on Foreign Relations.

Wolf Martin. 2013. 'Big trouble from little Cyprus', Financial Times, 19 March. 



\section{Mobilization of Protest in the Age of Austerity}

Hanspeter Kriesi

In a recent piece, McAdam and Tarrow (2010) discuss the question of the relationship between contention and convention in political action. Selfcritically, the authors observe that their joint effort (together with Tilly) to overcome the compartmentalization of studies concerning different forms of political action had given little attention to elections. They consider their inattention to the connection between elections and social movements 'a serious lacuna' in their Dynamics of Contention (McAdam et al. 2001), "as it is in the entire broad field of contentious politics" (532). To overcome the segmentation of the study of elections and social movements, they propose a series of six mechanisms that they believe "link movement actors to routine political actors in electoral campaigns". These mechanisms focus on how movements influence the electoral process: movements may turn into parties that participate in elections, or they may form within parties; they may introduce tactical innovations that can be adopted as electoral tools; they may become active in electoral campaigns or react to the outcome of elections. In my own attempt to link the two worlds of social movements and political parties, I have been interested in the opposite causal relationship, i.e. in the question of how political parties influence mobilization by social movements (Kriesi et al. 1995). In our comparative analysis of the mobilization of the new social movements, we were able to show that the configuration of the old and new left - and whether the left was in or out of government - made a key difference to their success.

I share McAdam and Tarrow's preoccupation with the segmentation of our discipline, because I believe that it fundamentally limits our possibilities to understand contemporary politics. In my view, however, previous attempts to come to terms with this segmentation are too partial and should be replaced by a more fundamental approach. Electoral choices and protest, mobilization by political parties and social movements are part and parcel of one and the same process of political interest intermediation that continuously links the different forms of interest articulation in the various channels and arenas of the political system. Taking the mobilization of protest in the age of austerity as the point of reference, I would like to formulate some general conceptual points as an introduction of such an 
approach, which I shall then go on to illustrate with the experience of protest mobilization in three countries - Greece, Spain, and the US - in the age of austerity.

\section{Conceptualization of the Relationship between Contention and Convention}

The literature on social movements tells us that political mobilization depends on the interaction between three sets of factors: grievances, organization, and opportunity. Grievances constitute the starting point: an exogenous shock like the financial and economic crisis creates a tremendous amount of popular discontent, which constitutes a latent mobilization potential. It is unlikely, however, that the crisis creates such mobilization potentials from scratch. In any given society, there are more or fewer latent mobilization potentials linked to the structural conflicts, which predate the crisis and which pre-structure the way the crisis mobilization will play out. The mobilization potential newly created by the crisis adds to this already existing stock of grievances that has already been present at the time of the intervention of the shock of the crisis. In different ways, the crisis may serve as a catalyst for protest mobilization. It may reshape an already ongoing mobilization process: it may redirect it by orienting it to new issues and goals, and it may reinvigorate it by intensifying the protest activities. Or it may trigger the articulation of mobilization potentials that have remained latent until the occurrence of the crisis.

People with grievances seek to express them, and they do so by raising their voice or by exiting (Hirschman 1970). They raise their voice to the extent that they are organized and have an opportunity to do so. In democratic societies, citizens have the right to vote and they have the opportunity to express their grievances as voters. As Piven and Cloward (1977: 15) have already noted a long time ago, "ordinarily, defiance is first expressed in the voting booth simply because, whether defiant or not, people have been socialized within a political culture that defines voting as the mechanism through which political change can and should properly occur". Accordingly, one of the first signs of popular discontent are sharp shifts in voting patterns. More generally, in democratic societies, the action repertoire of protests is likely to make use of the available institutionalized channels of access, which means that the privileged institutional spaces i.e. the privileged arena to voice grievances - are the electoral and, where available, the direct-democratic arena. In democracies, voters resort to the 
protest arena to the extent that they are unable to express themselves in the electoral or direct democratic channel, or to the extent that their vote has no impact.

The voters may not be able to express their discontent in the electoral arena because the next elections are too far off to provide an opportunity to voice their grievances. This constraint imposed by the electoral cycle is alleviated by the availability of elections at different levels - there are not only national but also local, regional, and European elections taking place at different moments in time and offering as many opportunities to voice discontent. Voters may use each one of these elections to protest against the governments and their policies at various levels. But even if elections are held sooner or later, they may not provide an opportunity to voice discontent because of the lack of a suitable alternative offered by the parties competing in the elections. The menu of alternatives provided by the parties is extended when new challengers mobilize in the electoral arena or when established mainstream parties transform themselves into new challengers. New challengers certainly have greater opportunities to enter into the fray and to make a difference in proportional systems than in majoritarian ones.

The literature on economic voting provides us with more precise ideas about how the crisis may have played out in electoral terms (Lewis-Beck and Stegmaier 2007; Duch and Stevenson 2008). This literature indicates that incumbents are generally punished in times of an economic crisis but that the impact is likely to vary as a function of context conditions (Powell and Whitten 1993; Hellwig and Samuels 2007; Duch and Stevenson 2008: chapter 9; Kriesi 2013). Specifically, this literature shows the importance of taking into account the kind of democracy (majoritarian vs proportional), the degree of institutionalization of the party system, and the openness of the national economy. It tends to suggest that the Great Recession is just another instance of economic distress, which has cyclical but no long-term effects on politics. Accordingly, the economic voting literature has largely failed to account for the kind of parties that may benefit when voters turn to punishing the governing parties (Van der Brug et al. 2007: 18-19; Tucker 2006: 4-5).

In a longer-term perspective, one could argue that the external shock of the Great Recession reinforces long-term trends in the West European party systems that have already been under way before the crisis. One such trend concerns the erosion of the mainstream parties' representation function. According to this trend, above all put into evidence by Katz and Mair $(1995,2009)$ and Mair $(2000,2002,2006)$, mainstream parties have moved 
their center of gravity from civil society to the state and have strengthened their governmental role to the detriment of their representation function. Mair (2000) summarized this development by what he called the rise of a 'partyless democracy'. What he had in mind was a largely neutral and non-partisan system of governance, appealing to a largely undifferentiated mass electorate whose relations with the institutions of government are no longer mediated to any significant extent. As the mainstream parties' representation function weakens, opportunities for populist protest in the party system increases. The decline of the parties' representation function invites populist reactions in the party system. Mair (2011: 14) expected, in fact, a division of labor within the party system between mainstream parties that habitually govern and take responsibility and parties that give voice to the people, i.e. that fulfill the representation function and that often adopt a rather populist style. He expected "a growing divide ... between parties which claim to represent, but don't deliver, and those which deliver, but are no longer seen to represent" (Mair 2002: 88). According to this thesis, by restricting the maneuvering space of the mainstream parties, the Great Recession has played into the hands of populist challengers within the party system by offering them the opportunity to mobilize against the mainstream parties and by presenting themselves as the true advocates of the people's will.

Such new challengers in the party system may be movements turned into parties, or, even more importantly, the challengers in the party system may be movements that have taken the form of parties in the first place. Arguably, the most important recent movements in Western Europe have been movements of the right, the new populist right, which have established themselves in the form of parties and have more or less explicitly avoided protest mobilization. The exogenous shock of the Great Recession might contribute to reinforcing the transformation of the partisan space driven by the rise of the new populist right that we have already observed in Western Europe before the crisis. As I have argued together with several colleagues in previous publications (Kriesi et al. 2006, 2008, 2012), globalization has transformed the basis of politics in Western Europe by giving rise to what we have called a new 'integration-demarcation' cleavage opposing globalization 'winners' and 'losers'. We suggested that the mobilization of the group of 'losers' by new challengers - parties of the new populist right and transformed established parties of the liberal and conservative right - has provided the key impetus for the transformation of the party systems in the six countries of our study - Austria, France, Germany, the Netherlands, Switzerland, and the UK. 
The paradox of the populists from the new right relying on party instead of movement politics is linked to a strategy of 'double differentiation', which is rooted in core value orientations of populist right leaders and followers (Hutter and Kriesi 2013). Both try to set themselves apart from their adversaries on the left, whom they view as 'chaotic' protesters, as well as from the extreme and neo-fascist right - not only for historical but also for more practical reasons. If those who openly advocate the most right-wing and racist ideologies take part in the mobilization by populist right parties, then the populists run the risk of being equated with them. For both the challengers on the left and on the right, the 'medium is the message', i.e. the choice of the channel in which they express themselves is at the same time an expression of their underlying message. While the rebels on the new left are libertarian and more post-materialist, the rebels on the new right have authoritarian and materialist values, and prefer (orderly) conventional political action over (disorderly) protest politics. In other words, at least in Western Europe, while the left protests in the streets, any protest from the right is found above all in the electoral arena.

If mobilization in the electoral channel is the most obvious choice, directdemocratic institutions are also increasingly available for the articulation of protest. As our comparative analysis of new social movements in Western Europe has shown, such institutions are readily used by social movements when they are available (Kriesi et al. 1995). Other institutional options for protest include litigation in courts. Kolb (2006) points out that courts provide access to the voices of those who might not otherwise be heard: "In contrast to the normal policy making process, access to and influence in the court system is not dependent on connections or social and economic position, but on the strength of legal arguments. In addition, judicial decisions can have important extra-judicial effects - such as creating publicity or increasing the bargaining power of social movements." Relying on courts for imposing reforms is, however, severely limited by the bounded nature of constitutional rights and by the fact that the judiciary is appointed by the other branches of government.

In the absence of available options in the institutionalized arenas discontented citizens have no choice but to resort directly to protest and to try to force political concessions from political elites by appealing to the general public. This is Schattschneider's idea (1960) of the expansion of conflict. Public protest is designed to unleash a public debate, to draw the attention of the public to the grievances of the actors in question, to create controversy where there was none, and to obtain the support of the public for the actors' concerns. Controversial public debates and support by the general public 
open up the access and increase the legitimacy of speakers and allies of the protest movements with journalists and with decision-makers who tend to closely follow the public debates (Gamson and Meyer 1996: 288). Wolfsfeld's 'principle of political resonance' (1997:47) formulates this relationship in the following way: challengers who succeed in producing events that resonate with the professional and political culture of important news media can compete with much more powerful adversaries.

In Western Europe and North America, however, citizens do not only resort to the contentious mobilization of protest today, if no other options are available. In Western Europe and North America, protest mobilization has become increasingly conventional, as these societies have become what is aptly called a 'movement society' by Meyer and Tarrow (1998). The term suggests that political protest has become an integral part of modern life; that protest behavior is employed with greater frequency and by more diverse constituencies, and is used to represent a wider range of claims than ever before; and that professionalization and institutionalization may be changing the social movement into an instrument of conventional politics. As protest becomes a part of everyday politics, we facilitate the "normalization of the unconventional" (Fuchs 1991). At the same time, social movement organizations become rather like interest groups. While protest becomes conventional, the typical repertoire of protest may still vary from one country to the other. Thus, in southern Europe, the political strike combined with large demonstrations constitutes a core element of the protest repertoire, while it is much less common or conventional in the north of Europe.

As unconventional forms of participation become increasingly accepted and political systems become more open to unconventional forms of mobilization, these forms are likely to become more moderate, less prominent, and less effective. As a result of its routinization, the protest repertoire loses some of its news value, its surprise effect, and its impact on the general public. As the repertoire of protest becomes routinized and loses its effectiveness, tactical innovations (McAdam 1983) become all the more important - innovations that catch the adversaries off guard and force them to innovate as well, i.e. to neutralize the challengers' moves through effective tactical counter-measures.

If a response to more or less conventional protest is not forthcoming, however, challengers, even in democracies, may not only try to innovate, they may also be tempted to step up their protest, to radicalize, and to create a political crisis through massive use of disruption (Keeler 1993). A political crisis can create a sense of urgency predicated on the assumption 
that already serious problems will be exacerbated by inaction. In addition, a political crisis can create a sense of genuine fear predicated on the assumption that inaction may endanger lives and property or even result in a revolution or coup d'état. When either of these mechanisms comes into play, the government may feel compelled to make substantive concessions to the challengers or, if it is unable to implement such concessions, fundamental realignments in the party system may occur. Latin America provides telling examples of party system collapse and realignments as a consequence of economic liberalization reforms in the aftermath of the debt crisis of the 1980s and 1990s (see Lupu 2012; Morgan 2013; Roberts 2013; Rovira Kaltwasser 2013).

Finally, it is also possible that the challengers come to reject the institutionalized channels of established democracies altogether. They may turn against representative democracy and the electoral process and demand more direct, participatory forms of democracy. This is, indeed, what the student movements of the late 1960 s and the new social movements of the 1970 and 1980 s have called for and what the New Left had been pursuing from the start. Thus, in the late 196os, exponents of the New Left had already denounced the deficiencies of existing representative models of democracy (e.g. Agnoli and Brückner 1968) and demanded more participatory forms of 'strong' democracy, as reflected in the scholarly literature of the day (Pateman 1970; Macpherson 1977; Barber 1984).

Whatever the action form and the political objective, political mobilization in both the institutional and the protest arenas requires an organizational infrastructure. In a democracy, the key political organizations are political parties, interest/advocacy groups, and social movement organizations (SMOs). Each type of organization focuses on a specific arena for its mobilization. Parties mainly, although not exclusively, mobilize in the electoral and the direct-democratic arenas, interest groups in the directdemocratic and the administrative arenas, and SMOs in the protest arena. In the absence of a political organization, the exit option - taking the form of apathy or of 'voting with the feet' - is the most likely reaction to grievances. This also applies if the established political organizations do not pick up the grievances of the population and if no new challenger is available. People who are not mobilized or who do not feel that the available options of mobilization allow them to express their grievances in any meaningful way are unlikely to move at all. In the electoral and direct-democratic arenas, this means low turnout; in the administrative arena, this means no lobbying; in the protest arena, this means no mass protest, no strikes, and no demonstrations. 


\section{The Dynamics of Contention and Convention in the Age of Austerity and the Transformation of the Party System}

The financial crisis constitutes an exogenous shock of an extraordinary magnitude. At first, governments focused their efforts on stabilizing their national banking systems and alleviating the negative impact on the real economy. They adopted bank rescue packages (Weber and Schmitz 2011; see also the chapter by Ross in this volume). They also countered the economic impact of the crisis by adopting modest fiscal expansionary measures (Armingeon 2012), relying on some version of liberal Keynesianism' (Pontusson and Raess 2012). Not all countries succeeded in reducing the short-term adverse effects of the crisis. Although the financial crisis had a severe impact on all the advanced industrial economies, the effect differed per country. As the crisis continued, governments generally changed policies and turned to austerity measures. In the case of the weaker economies, however, these measures largely failed to achieve their intended goal of reducing the public deficit. As a result, economic imbalances in Europe were aggravated, and the weaknesses in the EMU governance structures were revealed (Featherstone 2011; De Grauwe 2011; Eichengreen 2012). The ensuing complex policies of crisis management, which involved hard bargaining between European governments, their domestic constituents, and supranational actors (the European Commission, the ECB, the IMF, and the European Banking Authority), provided one of the key triggers for the political mobilization of grievances by European citizens in the face of the Great Recession.

My heuristic framework for the analysis of the interactive dynamics starts out with a set of five highly stylized political actors that includes: (1) international actors (such as the European Commission, the ECB, or the IMF), (2) the national government, (3) the (mainstream) opposition, (4) other (competing) public authorities (such as the [symbolic] president, the courts, [part of] the media, or the voters in a referendum vote) or established interest groups, and (5) outside challengers (populist parties, social movement organizations, trade unions, public interest groups). I assume that, in times of crisis, the international actors and the national governments have the initiative, while the other three types of actors may or may not react to the actions of these key actors. I am most interested here in the interaction between the mobilization of protest in the different channels and its impact on the party system in particular.

I shall look at three cases - the US, Greece, and Spain. In none of these three cases has the new populist right - i.e. a party defending the 
globalization 'losers' - had any significant electoral success before the crisis. In all of these countries, a rather majoritarian electoral system discourages the success of new challengers in the party system. Accordingly, Green parties have also been very weak or non-existent in these countries, and even strong new social movements have not left behind a legacy of strong party organizations ready to mobilize discontent in these countries. Another similarity between the three countries is that, at the moment the crisis hit, the left-wing incumbent government made it difficult, at first sight, for labor unions to organize any kind of mobilization.

\section{United States}

The focus on the interaction between contention and convention in the age of austerity suggests that we must broaden our view beyond 'street politics'. Indeed, in the age of austerity, mobilization has not only taken place in the streets. In fact, what I have called the most important recent movements in Western Europe - the movements of the new populist right - have established themselves in the form of parties and hardly mobilized in the streets at all. This is also true of the functional equivalent of the new populist right in the US - the Tea Party - that has launched the first and, I would argue, the most consequential mobilization against the US government in the age of austerity.

Compared to the Tea Party that started to mobilize against the new Obama Administration in early 2009, the Occupy movement came late - it only mobilized in the fall of 2011 - and it faded away as quickly as it came onto the public scene. As Gitlin (2013) suggests, it was more moment than movement. Tarrow (2011) has noted as much early on: "'[w]e are here' movements often flare up rapidly and fade away just as quickly, or disintegrate into rivulets of particular claims and interests". The number of people mobilized by the Occupy movement remained rather limited (they peaked at some ten to twenty thousand participants in the 5 October 2011 demonstration in New York City), and levels of support for the movement by the general public plunged rapidly. This does not mean that Occupy was inconsequential: the movement's slogan ("We are the 99\%") struck a responsive chord and entered into popular lore. "This was brilliant framing" (Calhoun 2013: 33) that drew media attention to the problem of rising inequality, and even if media attention did subside after the movement's eviction from Zuccotti Park, the broader political discourse continued "to be peppered with references to 'the 1 percent' and to other issues Occupy had raised" (Milkman et al. 2013: 38). However, Occupy did not seek a direct political impact. It 
did not target the government and its handling of the financial crisis but instead shifted the focus to inequality in society (Calhoun 2013: 33). As Gitlin (2013: 8) points out, the inner core of the movement "didn't want different policies; it wanted a different way of life". And it was "phobic about the risk of being coopted", even though such risks were rather limited given that its natural political ally, the Democratic Party, "handled the movement gingerly, for fear that any more intense expressions of friendliness might tar them with unruly brushes".

Contrary to the Occupy movement, the Tea Party movement has had considerable political impact, not least because it pre-empted the stage for mobilization by other movements. It has, of course, not been a reaction to austerity, but it reacted to the first 'liberal Keynesian' phase of the government's reactions to the crisis. Contrary to the Occupy movement, it targeted the government and it crucially shaped its natural ally - the Republican Party. Paradoxically, it mobilized against an administration that had inherited the mess from its predecessors and was trying to make the best of it by adopting the recipes already introduced by its predecessors, which were the recipes all the other governments applied at that time.

In presenting the case of the Tea Party, I essentially follow the study by Skocpol and Williamson (2012). The cast of characters is purely domestic in this particular case and includes the government (the incoming Obama Administration), the mainstream opposition (the Republicans), and three types of challengers: 1) grassroots local groups, composed of a gaggle of about 1,00o local groups (in 2011), not particularly well-coordinated and none of them directly controlled by the Republican party; 2) professional national advocacy groups ('idea pushers'), top-down organizations leveraging grassroots activism to gain new advantage, financed by a few billionaire families, especially the Koch family, whose resources allow them to push their own world view in civic and political affairs; 3 ) the highly partisan sector of the conservative media complex - including Fox News, the right-wing blogosphere, and nationwide networks of right-wing talk radio programs. The grassroots organizations got the movement off the ground, the conservative advocacy groups jumped on the bandwagon, and the conservative media quickly joined and helped to orchestrate the movement, breaking down the barriers between media and movement that have usually been so challenging for protesters to navigate. The thrust of local and national Tea Party activism through the November 2010 elections was maximized by loosely connected organizational efforts. The relationship between the local chapters and the national advocacy groups was loose and mutually beneficial, allowing the advocacy groups to set the agendas and disseminate 
general arguments without becoming accountable to the local groups. The conservative media - Fox in particular - served as a kind of social movement orchestrator during the critical early period of initial mobilization: they forged a community of meaning. As a result of the segmentation of the public sphere, the Tea Party activists often unblinkingly believed wildly inaccurate things about what government does, how it is financed, and what is actually included in key pieces of legislation or regulation (Skocpol and Williamson 2012: 199).

Tea Party efforts moved forward within and across the edges of the Grand Old Party (GOP) but never came under party control. However, the movement had its greatest effect in the mid-term elections of 2010, when the Republicans gained 63 seats and control of the House, and took control of both the governorships and the legislatures in twelve states. The Democrats ended up with control of the fewest state legislative bodies they have had since 1946 (Drew 2013). Of course, the economic recession and high unemployment helped the opposition party, but the Tea Party and selective participation helped, too: the participation rate fell from 61.6 per cent in the 2008 elections to 41.6 per cent in the 2010 mid-term elections. Mid-term voters tend to lean to the Republicans, but in 2010 this was even more the case than usual thanks to the mobilization by the Tea Party. As Skocpol and Williamson put it: "The Tea Party and their adoring media surely helped re-inspire grassroots conservatives, set a national agenda for the election, and claim a Republican-wave election as vindication for a particular, extreme conservative ideology" (2012: 163). And Drew (2013) maintains that the 2010 elections were the single most important event leading up to the domination of the House by the Republican far right.

The bigger story is, indeed, the impact of the Tea Party on the GOP. The Republican Party has been moving toward the right for some time, and that movement only quickened after the advent of the Tea Party. The Republicans newly elected in 2010 were much more to the right than the outgoing Republicans. Moreover, the Tea Party activists fulfilled 'watchdog functions', barking at the heels of the GOP. They took over local committees, which is significant because Republicans who want to run for election or reelection to state legislatures and Congress will think twice before ignoring the stated policy preferences of even relatively small Tea Party minorities in their districts. According to Skocpol and Williamson (2012: 183), the Tea Party's ultimate impact on Congress - and on state legislatures - lies in its capacity to coordinate national pressure from wealthy funders and ideological advocates with contacts from grassroots Tea Partyers who have a reputation for clout in local districts. When coordinated pressure can be 
mounted - as it has been in budget battles - the Tea Party delivers a loud and clear absolutist message to legislators, a message that comes both from advocates in Washington DC and from local districts. Although the symbolism of 'the Tea Party' is already fading in popularity, the power of hard-right ideologues consolidated during the first years of the Obama Administration is continuing to drive Republican politics, crowding Republicans into an ultra-right corner and contributing to the paralysis of the American political system (Drew 2013).

\section{Greece}

Greece has been arguably the country hardest hit by the Great Recession. It goes without saying, then, that anti-austerity protests appear to have been much more intense in Greece than elsewhere. International actors played a key role in how Greece dealt with the crisis and became, together with the government, the key target of the protests. The mainstream opposition did its best to undermine the government without openly joining the challengers, who were mainly organized by the (old) radical left and the trade unions. The government's anti-austerity measures - whether unilaterally adopted (at first) or imposed by the Troika (beginning with the first Greek bailout in May 2010) - triggered the mobilization. The series of large-scale mobilizations was a direct response to the series of measures imposed by the government on an increasingly alienated population.

Timing is again crucial. Just as in the case of the US Tea Party, the movement got off the ground only once a new government was voted into office. In the fall of 2009, the Greeks had the possibility to sanction the incumbent government in national elections. With a rapidly burgeoning public deficit necessitating increasingly tough austerity measures, the conservative Prime Minister Karamanlis announced in a dramatic televised address on 2 September 2009 the dissolution of parliament and early elections on 4 October, only two years after the previous one. As in 2007, Karamanlis sought to pre-empt the further erosion of electoral support for his government and to ensure the shortest possible campaign. But this time, he did not get away with it. Under the pressures of the economic crisis, Karamanlis's centerright New Democracy party (ND) could only promise austerity measures to decrease the runaway public debt. In sharp contrast, Pasok, the socialist party in opposition, offered not only a stimulus package to boost demand but also the vague prospect of 'green development' as a new model for the country. George Papandreou cheerfully proclaimed that the country's problem was not the lack of resources but only their mismanagement. This 
was enough to hand him the premiership after an overwhelming victory at the polls (Mavrogordatos and Marantzidis 2010: 997f). The elections constituted a typical example of economic voting: the incumbents were seriously punished and the mainstream opposition took over: Pasok won 5.8 per cent, rising to 43.9 per cent, while ND lost 8.3 per cent, dropping to 33.5 per cent, its lowest percentage ever. The radical left (KKE and Syriza) also lost some votes.

The new socialist government under George Papandreou was, however, quickly hit by the tough reality of the economic crisis. In December 2009, the new government admitted that the public debt figures had been manipulated by previous governments and that Greece was actually burdened with public debt amounting to 113 percent of GDP - nearly double the Eurozone limit of $6 \mathrm{o}$ percent. Rating agencies started to downgrade Greek bank and government debt. In January 2010, an EU report condemned Greece for "severe irregularities" in its accounting procedures. Its budget deficit in 2009 was revised upwards from 3.7 per cent to 12.7 per cent, more than four times the maximum allowed by EU rules. Instead of a stimulus program, the Papandreou government was forced to implement a series of austerity measures in February 2010. These measures were immediately opposed by political forces further to the left. In spite of the fact that it was a socialist government who was forced to take these measures under heavy international pressure, the unions and the radical left (KKE and Syriza) mobilized against the government's austerity program. They believed that Pasok had "lost its soul". As a result of the crisis, both major political parties had thus lost legitimacy. The master frame of the protestors was mobilizing against the political corruption symbolized by parliament. One of the central slogans was "burn, burn the brothel called Parliament" (Psimitis 2011: 196).

Over the next three years, Greece saw no less than 27 general strikes against the austerity programs. In addition to general strikes, Greece experienced large-scale demonstrations, sit-ins, arson attacks against public buildings, and widespread destruction of private property, verbal and physical attacks against MPs and the parliament, and terrorist attacks, many of which were directed against immigrants. The anti-austerity protests in Greece undoubtedly constitute a mass movement in which, according to the estimates of Karyotis and Rüdig (2013), no less than 30 per cent of the entire population was engaged in one way or another in 2010. In spite of the large-scale mobilization of this movement, at its core, this was a movement rooted in Greece's traditional left-wing political culture. As Karyotis and Rüdig (2013) argue, at the time of the outbreak of the crisis, Greece had a large reservoir of people who had previously been engaged in 
protest and on whom any protest mobilization may have been able to draw. This was essentially a left-leaning protest potential that was part of what Andronikidou and Kovras (2012: 712) have called "a deep-rooted culture of resistance" that was extended during the crisis. Already before the crisis, the frequency of general strikes - which were a regular feature of Greek life well before the austerity protests - made Greece clearly stand out from other countries. Moreover, the role of trade unions in mobilizing people for these strikes had been crucial already before the crisis.

What the analysis of Karyotis and Rüdig clearly shows is the importance of this potential for the mobilization of anti-austerity protests in 2010. Previous protest involvement turns out to be the most important predictor of involvement in anti-austerity protests. Those who have been involved in both strikes and demonstrations multiple times before are the most likely to take part in anti-austerity protests as well. The traditional network of trade union and voluntary group membership, as well as public sector employment, played a crucial role in recruiting protesters for the previous protests as well as for the anti-austerity protests. Once previous participation is controlled for, none of these network factors is a predictor of protest. For Karyotis and Rüdig (2013: 22), it is "beyond doubt that antiausterity protest involves, to a large extent, mobilizing an existing pool of experienced strikers and demonstrators". While grievances (relative deprivation) are significant predictors of opposition to austerity policies and support for protest, they do not predict turning potential into actual participation.

Karyotis and Rüdig also show that this is not a middle class or 'new' social movement. Instead, the Greek anti-austerity movement is a movement of ordinary people of all educational backgrounds and ages. It includes people fully involved in economic life, not people at the margins of the labor force. Only people with a job can take part in a strike, after all. What seems plausible is that "the usual suspects in Greece, through their organizational infrastructure, act as first movers in the generation of protest opportunities, who trigger the latent protest socialization of a broader public that is not strongly defined ideologically in left-right terms" (239). No less than 29 per cent of Karyotis and Rüdig's representative national sample indicated that they had previously participated in either strikes or demonstrations or both.

This enormous mobilization, which continued through 2011, had farreaching consequences for electoral politics. Eventually, Greece experienced a deep political crisis that culminated in the collapse of its party system during the consecutive parliamentary elections of May and June 2012. In the local elections that took place in November 2010, the two mainstream 
parties seemed to hold out. The incumbent socialists (Pasok) took a beating (dropping by 9.3 per cent), but they still came out ahead with 34.7 per cent nationwide, compared to 32.8 per cent of the conservative ND (-0.7 per cent). However, there were already signs of a fundamental change as well: the analysis of Karyotis and Rüdig reveals the weakness of Pasok's support base at the time already. This weakness manifested itself, among other things, in the weak turnout: for the first time in memory, more than half of all eligible voters abstained in the second round. Moreover, almost 30 per cent of mayors who won run-off contests around the country were independents. ${ }^{1}$ In addition to independents, the clear winner was the old communist left, which benefited from a year of intense mobilization but still only to a limited extent $(+3.3$ per cent for a new total of 10.9 per cent). Syriza remained stagnant at 4.5 per cent.

Although the mid-term program of fiscal consolidation was adopted in June 2011, Papandreou continued to lose power and credibility. The second Greek bailout in July 2011 accelerated the decay. It was then that Papandreou made the fateful decision to submit the second bailout agreement to a national referendum. The European leaders, who had fought hard for this agreement, felt betrayed by his decision; both Merkel and Sarkozy made it clear that if Greece wanted to have a referendum, it could be only about the country's continued membership of the Eurozone. In the ensuing turmoil, Papandreou was forced to resign. He was replaced by a technocratic government under the leadership of Lukas Papademos, the ex-director of the Greek National Bank. Reluctantly and only under pressure from the Troika, the conservative opposition (ND) agreed to give its vote of confidence in the new government. In the aftermath of the second bailout, the two mainstream parties started to disintegrate and the party system reconfigured under the impact of a new political conflict opposing the partisans and foes of the bailout agreement (Dinar and Rori 2013: 274-276). Two interrelated issues dominated the campaign in May: the bailout agreement and punishment of the political elites who were responsible for the crisis. Based on data from the European Manifesto Project, Halikiopoulou et al. (2012) show that, on the new political conflict dimension of the bailout issue, the two pro-European mainstream parties were radically opposed by the smaller opposition parties from the left (KKE and Syriza) and the right (LAOS). This new conflict could be regarded as the Greek version of the 'integration-demarcation' cleavage that we have identified in northwest European countries. The specifically Greek aspect is that this conflict has 
predominantly been articulated by a populist left (KKE and Syriza). For the communists (KKE) in Greece and elsewhere, the EU is a product of imperialism, which the radical left opposes in an attempt to protect the nation (equated with class), its territory, and sovereignty. Syriza, by contrast, adopted an ambiguous position: while radically in favor of punishing the incumbents and opposed to the bailout agreement, it wanted to stay in the Eurozone. LAOS ended up supporting the technocratic government, which was equivalent to signing its death warrant in the upcoming elections. The fragmentation of the mainstream parties added to the forces opposed to the bailout. When early elections were announced in April 2012, the Greek party system had very little in common with what it had been in 2009. Fragmentation and polarization reigned on both sides of the political spectrum.

The punishment of the two major parties was exemplary: together they lost no less than 45 per cent of their 2009 votes, jointly obtaining no more than 32 per cent. Pasok was literally destroyed, losing more than 30 per cent, but ND was not able to benefit from this collapse and also lost 15 per cent. The winning anti-bailout forces were, however, too fragmented to be able to form a government. The election resulted in a deadlock, which led to the organization of a second election in June. The June election saw a limited comeback of ND to become the largest party with 29.7 per cent. The big winner of the elections was, however, Syriza, a party that had started out in 2004 as a confederation of leftist organizations, which were, in turn, split-offs from the communist party (Moschonas 2013: 35). Gaining votes mainly from Pasok, KKE, the Greens, and other smaller parties of the left, Syriza rose to become the second strongest party in the June election, only three percentage points below the leading party (Dinar and Rori 2013: 279). Moschonas suggests that "without the shock of the economic crisis, Syriza's meteoric rise would not have occurred, and without Aléxis Tsípras's leadership and strategy, Syriza would not have become the main party of opposition" (2013: 36). The collapse of Pasok and the rise of Syriza closely resemble the experience of Latin American countries, where parties of the left had to implement neoliberal reform programs and, in the process, diluted their party 'brand' to such an extent that their voters lost their party identity and abandoned them for a populist alternative (such as Hugo Chavez in Venezuela). In the early Greek elections in January 2015, Syriza won the elections with 36.3 per cent of the vote and was able to form a government together with the right-wing populists of ANEL (Independent Greeks). 


\section{Spain}

The Spanish Indignados movement also began rather late in the financial crisis, in May 2011. It was preceded by huge demonstrations in Portugal in March 2011, which were triggered by four young university graduates mobilizing their 'lost generation' ('geração à rasca') via Facebook. Some 200,000 persons took part in this not only peaceful but festive event in Lisbon, and 80,000 in Porto. The discontent expressed in these demonstrations was fuelled by the announcement of another set of austerity measures (by then the fourth one in Portugal). At about the same time, Spanish students also began protesting massively against education cuts, calling attention to their unpromising future. The Spanish Indignados followed two months later.

As shown in the contribution by Perugorría, Shalev, and Tejerina in this volume, the Spanish Indignados were mainly composed of those with leftwing sympathies but, like the Occupy movement in the US, they did not want to be associated with any established political force. For the Indignados movement was not only an outcry against politicians and bankers and a call for social justice, it was also a critique of the way Spanish democracy functioned and a demand for real democracy now, i.e. for more participation, transparency, accountability, and proportional representation. It was a protest against politicians and parties, against the powerlessness of politics in coping with the economic problems created by the crisis. Similar to their Portuguese predecessors, the Indignados mobilized people through trusted social networks without formal ties to established organizations. Compared to other protest movements in Spain, the Indignados were younger, less male-dominated, more highly educated, and less organized, although they had a roughly equal amount of previous experiences with unconventional participation (Anduiza et al. 2013). If anything, this was a movement of the new left, comparable to the movements of the late 1960s and early 1970 in the northwest of Europe. Its rejection of formal organizations and established elites and its call for real democracy resemble the original call of the new left for participatory democracy and autonomous cultural spheres. Contrary to the limited mobilization capacity of the Occupy movement, this Spanish movement reached high rates of active participation. As reported in the chapter by Perugorría, Shalev, and Tejerina in this volume, the overall active participation rate was 11 per cent of the Spanish population, which is lower than the corresponding rates in Israel and Greece but higher than active participation in the famous French revolt of May 1968, when the participation rate reached 8 per cent for the whole of France (although up to 30 per cent in the 'hottest' regions) (Converse and Pierce 1986). 
Why was there such a lag between the outbreak of the financial crisis and the emergence of the Indignados movement? One reason for the lack of protest was that the Spanish socialist government was late in taking austerity measures. The government expected public debt to stabilize at 70 per cent of GDP, up from 60 per cent but well below the euro-area average. It was only after much initial hesitation that the Socialist Zapatero government took some tough measures, which included cuts in the salaries of public sector employees, a freezing of pensions, and a loosening of employee protection against dismissal. Another reason is that the Spanish unions, although well-known for their radicalism, did not conspicuously mobilize against their government's austerity measures. In spite of their militancy, the Spanish unions had adopted a cooperative stance and have participated in corporatist arrangements ever since the Moncloa Pact, which established the Spanish social partnership system after the transition to democracy in 1977 (Pérez 200o). Unlike the Greek unions, the Spanish unions maintained a close relationship with the socialist government.

If the Spanish unions did mobilize against austerity, they did so mainly in the framework of cross-European events. The European Trade Union Confederation (ETUC) organized two European days of action for a joint protest across Europe. The first one - called 'Fight the crisis: Put the people first' - was organized in May 2009. The campaign was launched with a demonstration on 14 May in Madrid, with the support of some 150,000 participants. This event was followed by a demonstration on 15 May in Brussels, involving about 50,000 participants, and by further events on 16 May in Berlin (100,00o participants) and in Prague (30,000 supporters). Demonstrations were also held in other European countries, including Bulgaria, Poland, Slovakia, and the UK. A second European day of action followed in September 2010, when tens of thousands of protesters took to the streets across Europe as strikes and demonstrations caused widespread disruption. In addition to Brussels (around 100,000 participants), the main action took place in Greece, and again in Spain. On the second day of union action across Europe, Spanish unions organized the first general strike in eight years, protesting against the austerity measures of their government. The result of the strike was acceptable for both sides: the unions were able to save face, and the government was not really threatened. "Rarely can a general strike have been so placid”, commented The Economist ${ }^{2}$. The government all but laid down a red carpet for the unions. The Spanish prime minister Zapatero had sweetened the pill by announcing a tax increase for 
the rich in 2011. The unions seemed to be performing more out of a sense of duty than rage. The mutual restraint can only be explained by the fact that the Spanish socialists have been the unions' traditional allies.

In January 2011, however, it seemed very likely that the unions would call another general strike, triggered by the government's announcement of a rise in the retirement age from 65 to 67 . But under pressure from a deteriorating economy and expected socialist losses at the coming municipal elections in May, the unions and the government (together with the business confederation) got together to negotiate a new social pact instead. After two weeks of intense negotiations, the three partners agreed on a pact to revive the economy and to cut the soaring unemployment rate (especially among the young). The main reform consisted of the previously announced measure to gradually raise the retirement age from 65 to 67 starting in 2013 .

Just as the Greek incumbents, the Spanish socialists were in for a severe electoral lashing. Not only had they underestimated the crisis for too long, once they began taking measures against the crisis, these proved to be incapable of improving the situation. In the first elections after their announcement of austerity measures in May 2010 - the regional elections in Catalonia - the socialists had already lost heavily to the regionalists, and to the conservative People's Party (PP), its main opponent at the national level. In local elections held in May 2011, right around the time of the Indignados' initial mobilization, the socialists once again received a severe beating. In these elections, which had a rather high participation rate, the conservative PP became the largest party. These defeats forced Prime Minister Zapatero to step down and to call for early national elections in November 2011. In these elections, the socialists lost a record amount of 15.1 per cent, obtaining only 28.8 per cent of the vote. The winner was once more the conservative opposition, which gained 4.7 per cent for a total of 44.6 per cent and an absolute majority in the Cortès.

Thus, just as in France in 1968 when the voters returned General de Gaulle to power after the May events (Converse and Pierce 1986: 413-484), the Indignados did not seem to have any impact on the electoral outcome. However, more recent developments suggest that this would be too hasty a conclusion to draw. As a matter of fact, the Spanish public quickly became disillusioned with the new conservative government, too. For one thing, it proved as incapable as the socialists of leading Spain out of the depression. Indeed, the level of unemployment continued to increase under the new government. In addition, the new government was shaken by a series of corruption scandals that greatly undermined the credibility of the conservative prime minister. As a result, mobilization against the government has 
broadened. The sentiment of not being represented by any party or union spread beyond the ranks of the Indignados, and by the end of 2012, there was hardly a day without a demonstration or a strike in the Spanish capital ${ }^{3}$. A movement against foreclosures enjoyed unexpected success, and the number of action committees to defend the interests of ordinary citizens increased. Most importantly, the monthly polls of the electorate have indicated a steady decline of the PP's support. By early 2015, it had dropped down to around 25 per cent. At the same time, however, the socialists have not been able to benefit from the decline in support for their main adversaries, but have instead stagnated at the level of support they obtained in the last national elections. The voters have been turning to either Podemos, a new radical left-wing party that grew out of the Indignados movement, or to Ciudadanos, a new center-right party that originated in Catalonia but has mobilized more broadly in recent years. In the 2014 European elections, Podemos, which had just been created, obtained 8 percent of the vote, while Ciudadanos polled 3.2 percent. In the regional and local elections in the spring of 2015, left-wing coalitions close to Podemos won the race for mayor in the two largest Spanish cities, Madrid and Barcelona. In the 20 December 2015 national legislative elections, Podemos gained 20.7 per cent of the vote and Ciudadanos 13 per cent.

The three cases presented in this paper serve to illustrate the two key points that I wish to make. First, they show that the movements spawned by the Great Recession differ greatly from one country to the other, making it difficult to generalize. In the case of the US, the key movement has been a conservative one. In Greece, it has been a movement of the old left. In Spain, it has been a movement that claims to be neither left nor right but that, if anything, resembles the new left of the late 1960 s in the northwest of Europe. This brings me to my second point: the make-up of the movements in the age of austerity depends on the national political context. In all three countries, the target of the mobilization was the incumbent government, and in all three countries, this government was a centre-left government - the Democrats in the US and the socialists in Greece and Spain. But these governments were challenged for quite different reasons, and the opposition that benefited from the challenge was quite different, too. However - and this is a point that all three cases share - the mobilization by the movements 
had a tremendous impact on electoral politics, the party system, and the political process more generally.

In the US, the government was challenged not for its austerity measures but for its liberal Keynesianism. The opposition that benefited was the mainstream opposition. Given the US two-party system, any movement seeking to impose its view in politics can try to capture one of two parties the Republicans in the case of conservative movements, and the Democrats in the case of progressive movements - or it can try to run a third-party campaign. A precedent to the Tea Party's capture of the Republicans is the presidential campaign of Barry Goldwater (1964); precedents on the progressive side are the presidential campaigns of William J. Bryan (1896), Franklin D. Roosevelt (1932-40), and Eugene McCarthy (1972). Third-party candidates have tried as well: George Wallace or Ross Perrot on the right, or Ralph Nader on the left.

In Greece and Spain, the governments were challenged for their austerity policies, but the challengers in the two countries were quite different from each other. The Greek challenge was carried out by a broad popular movement that was rooted in the traditionally rather radical left subculture, but expanded beyond it. The movement destroyed not only the Greek socialist party but also the Greek party system in which two major parties pursuing centrist strategies dominated. It replaced the socialists by a new party on the left whose main characteristic is that it opposed the austerity policies imposed by the second bailout agreement. At the same time, it replaced the centripetal competition in the party system by a polarized competition. In Spain, by contrast, the movement constituted a new political force that did have roots in the left political culture but did not associate itself with the political organizations of the left. Its apolitical character explains why, at first, it did not have much impact on the party system other than that it contributed to undermining the incumbent government. In the long run, however, this movement may influence Spanish politics and society in an even more fundamental way than the Greek protest. While the Greek protest was purely reactive and concentrated on the austerity measures imposed by the government and its international backers, the Spanish protest took a broader view and contained a utopian element: a promise of a better society beyond a world of austerity and the restitution of traditional privileges. The Spanish movement may eventually not only contribute to the transformation of the Spanish party system but also to the transformation of Spanish democracy in a more fundamental way, just as the new left in the northwest of Europe had done back in the late 196os and 1970s. As Fuchs and Klingemann (1995: 435) have argued, in the aftermath of the 'silent 
revolution' of the late 1960s and 1970s, a 'democratic transformation' took place in these countries, involving a change in the interaction between the actors of the polity and the public, a process that actually produced greater responsiveness on the part of the major political actors towards citizens' demands. There was a process of successful adaptation of representative democracy to the new participation demands of their citizens, and the emergence of new collective actors who articulated new issue demands in their collective actions. Citizens became generally more active as well as more effective in the political process.

\section{Bibliography}

Agnoli Johannes, Brückner Peter. 1968. Die Transformation der Demokratie. Frankfurt: Europäische Verlagsanstalt.

Andronikidou Aikaterini, Kovras Iosif. 2012. 'Cultures of Rioting and Anti-Systemic Politics in Southern Europe', West European Politics, 35 (4): 707-725.

Anduiza Eva et al. 2013. 'Mobilization through Online Social Networks: The Political Protest of the Indignados in Spain', Information, Communication \& Society, 17 (6): 1-15.

Armingeon Klaus 2012. 'The Politics of Fiscal Responses to the Crisis 2008-2009', Governance, 25 (4): 543-565.

Barber Benjamin. 1984. Strong democracy: participatory politics for a new age. Berkeley: University of California Press.

Calhoun Craig. 2013. 'Occupy Wall Street in perspective', British Journal of Sociology, 64 (1):26-38.

Converse Philip E., Pierce Roy. 1986. Political Representation in France. Cambridge: The Belknap Press of Harvard University Press.

De Grauwe Paul. 2011. 'The Governance of a Fragile Eurozone', CEPS Working Document No. 346.

Dinar Elias, Rori Lamprini. 2013. 'The 2012 Greek Parliamentary Elections: Fear and Loathing in the Polls', West European Politics, 36 (1): 270-82.

Drew Elizabeth. 2013. 'The Stranglehold on Our Politics', New York Review of Books, 26 September.

Duch Raymond M, Stevenson Randoph S. 2008. The Economic Vote. How Political and Economic Institutions Condition Election Results. Cambridge: Cambridge University Press.

Eichengreen Barry. 2012. 'European Monetary Integration with Benefit of Hindsight', Journal of Common Market Studies, 50 (S1): 123-136.

Featherstone Kevin. 2011. 'The Greek Sovereign Debt Crisis and EMU: A Failing State in a Skewed Regime', Journal of Common Market Studies, 49 (2): 193-217.

Fuchs Dieter. 1991. 'The Normalization of the Unconventional: New Forms of Political Action and New Social Movements', in Meyer Gerd, Ryszka Franciszec (eds.), Political Participation and Democracy in Poland and West Germany. Warsow: Wydaeca, 148-169.

Fuchs Dieter, Klingemann Hans-Dieter. 1995. 'Citizens and the State: A Relationship Transformed', in Klingemann Hans-Dieter, Fuchs Dieter (eds.), Citizens and the State. Oxford: Oxford University Press, 419-443.

Gamson William A., Meyer David S. 1996. 'Framing political opportunity', in McAdam Doug et al. (eds.), Comparative Perspectives on Social Movements. Political Opportunities, Mobilizing Structures, and Cultural Framings. Cambridge: Cambridge University Press, 275-29o. 
Gitlin Todd. 2013. 'Occupy's predicament: The moment and the prospect for the movement', British Journal of Sociology, 64 (1): 3-25.

Halikiopoulou Daphne et al. 2012. 'The paradox of nationalism: The common denominator of radical right and radical left euroscepticism', European Journal of Political Research, 51: 504-539.

Hellwig Timothy, Samuels David. 2007. 'Voting in Open Economies. The Electoral Consequences of Globalization', Comparative Political Studies, 40 (3): 283-306.

Hirschman Albert O. 1970. Exit, Voice and Loyalty: responses to decline in firms, organizations, and states. Cambridge: Harvard University Press.

Hutter Swen, Kriesi Hanspeter. 2013. 'Movements of the Left, Movements of the Right Reconsidered', in van Stekelenburg Jacquelien et al. (eds.), The Future of Social Movement Research. Dynamics, Mechanisms, and Processes. Minneapolis: University of Minnesota Press, 281-298.

Karyotis Georgios, Rüdig Wolfgang. 2013. 'Blame and Punishment? The Electoral Politics of Extreme Austerity in Greece', Political Studies. Doi: 10.1111/1467-9248.12076.

Katz Richard S., Mair Peter. 2009. 'The Cartel Party Thesis: A Restatement', Perspectives on Politics, 7 (4): 753-766.

-. 1995. 'Changing Models of Party Organization and Party Democracy: The Emergence of the Cartel Party', Party Politics, 1 (1): 5-28.

Keeler John TS. 1993. 'Opening the window for reform. Mandates, crises, and extraordinary policy-making', Comparative Political Studies, 25 (4): 433-486.

Kolb Felix. 2006. Explaining the political outcomes of social movements: anti-nuclear energy mobilization in 18 OECD countries before the Chernobyl accident. Unpubl. ms.

Kriesi Hanspeter. 2013. 'The Political Consequences of the Economic Crisis in Europe. Electoral Punishment and Popular Protest', in Bermeo Nancy, Bartels Larry M. (eds.), Mass politics in tough times. Oxford: Oxford University Press, 297-333.

Kriesi Hanspeter et al. 1995. New social movements in Western Europe. A Comparative Analysis. Minneapolis: University of Minnesota Press.

-. 2006. 'Globalization and the transformation of the national political space: six European countries compared', European Journal of Political Research, 45 (6): 921-957.

- . 2008. West European Politics in the Age of Globalization. Cambridge: Cambridge University Press.

-. 2012. Political conflict in Western Europe. Cambridge: Cambridge University Press.

Lewis-Beck Michael S., Stegmaier Mary. 2007. 'Economic Models of Voting', in Dalton Russell J., Klingemann Hans-Dieter (eds.), The Oxford Handbook of Political Behaviour. Oxford: Oxford University Press, 519-537.

Lupu Noam. 2012. Brand Dilution and the Breakdown of Political Parties in Latin America. Unpubl. Ms.

Macpherson C.B. 1977. The life and times of liberal democracy. Oxford: Oxford University Press.

Mair Peter. 200o. 'Partyless Democracy and the "Paradox" of New Labour', New Left Review, 2: 21-35.

—. 2002. 'Populist democracy vs Party Democracy', in Mény Yves, Surel Yves (eds.), Democracies and the Populist Challenge, Basingstoke: Palgrave, 81-98.

—. 2006. 'Ruling the void? The hollowing of Western Democracy', New Left Review, 42: 25-51.

-. 2011. 'Bini Smaghi vs. the Parties: Representative Government and Institutional Constraints', EUI Working Paper, RSCAS 2011/22.

Mavrogordatos George T., Marantzidis Nikos. 2010. 'Greece', European Journal of Political Research, 49: 991-1000. 
McAdam Doug. 1983. 'Tactical innovation and the pace of insurgency', American Sociological Review, 48: 735-754.

McAdam Doug. et al. 2001. Dynamics of Contention. Cambridge: Cambridge University Press.

McAdam Doug, Tarrow Sidney. 2010. 'Ballots and Barricades: On the Reciprocal Relationship between Elections and Social Movements', Perspectives on Politics, 8 (2): 529-42.

Meyer David S., Tarrow Sidney. 1998. 'A Movement Society: Contentious Politics for a New Century', in Meyer David S., Tarrow Sidney (eds.), The Social Movement Society. Lanham: Rowman\&Littlefield, $1-28$.

Milkman Ruth et al. 2013. Changing the Subject: A Bottom-up Account of Occupy Wall Street in New York City. CUNY: The Murphy Institute.

Morgan Jana. 2013. Bankrupt representation and party system collapse. University Park: The Pennsylvania State University Press.

Moschonas Gerassimos 2013. 'A New Left in Greece. PASOK's Fall and SYRIZA's Rise', Dissent, Fall: 33-37.

Pateman Carol. 1970. Participation and democratic theory. Cambridge: Cambridge University Press.

Pérez Sofia A. 200o. 'From Decentralization to Reorganization. Explaining the Return to National Bargaining in Italy and Spain', Comparative Politics, 32 (4): 437-458.

Piven Francis Fox, Cloward Richard A. 1977. Poor People's Movements. Why They Succeed, How They Fail. New York: Vintage Books.

Pontusson Jonas, Raess Damien. 2012. 'How (and Why) is This Time Different? The Politics of Economic Crisis in Western Europe and the United States', Annual Review of Political Science, 15: 13-33.

Powell G. Bingham, Whitten Guy D. 1993. 'A cross-national analysis of economic voting: taking account of the political context', American Journal of Political Science, 37: 391-414.

Psimitis Michalis. 2011. 'The protest cycle of spring 2010 in Greece', Social Movement Studies, $10(2): 191-97$.

Roberts Kenneth M. 2013. 'Market Reform, Programmatic (De)alignment, and Party System Stability in Latin America', Comparative Political Studies, 46 (11): 1422-1452.

Rovira Kaltwasser Cristóbal, 2013. 'Elections in Europe in a Time of Crisis: Lessons from Latin America', The European Union Democracy Observatory Conference, EUI, 28-29 November.

Rüdig Wolfgang, Karyotis Georgios. 2013. 'Who Protests in Greece? Mass Opposition to Austerity', British Journal of Political Science, June: 1-27.

Schattschneider, Elmer E. (1975 [1960]). The Semisovereign People. New York: Wadsworth Thomson Learning.

Skocpol Theda, Williamson Vanessa. 2012. The Tea Party and the Remaking of Republican Conservatism. Oxford: Oxford University Press.

Tarrow Sidney. 2011. 'Why Occupy Wall Street is Not the Tea Party of the Left', Foreign Affairs, 10 October.

Tucker Joshua A. 2006. Regional Economic Voting. Russia, Poland, Hungary, Slovakia and the Czech Republic, 1990-1999. Cambridge: Cambridge University Press.

Van der Brug Wouter et al. 2007. The Economy and the Vote. Economic Conditions and Elections in Fifteen Countries. Cambridge: Cambridge University Press.

Weber Beat, Schmitz Stephan W. 2011. 'Varieties of helping capitalism: Politico-economic determinants of bank rescue packages in the EU during the recent crisis', Socio-Economic Review (9): 639-669.

Wolfsfeld Gadi. 1997. Media and Political Conflict. News from the Middle East. Cambridge: Cambridge University Press. 


\title{
4 The Spanish Indignados and Israel's Social Justice Movement
}

\author{
The Role of Political Cleavages in Two Large-Scale Protests \\ Ignacia Perugorría, Michael Shalev and Benjamín Tejerina
}

The $15 \mathrm{M}$ movement in Spain (15 May 2011) is widely regarded as the vanguard of the "networks of outrage and hope" or "occupy social movements" that swept several southern European states (Castells 2012; Tejerina et al. 2013b)'. Unlike Occupy Wall Street, the Spanish Indignados featured not only encampments and assemblies of the young but also very large protest events and wide public support. The mass demonstrations that occurred in Madrid's Puerta del Sol and elsewhere mobilized participants with social and political profiles quite different from previous protest events and social movements (Anduiza et al. 2013). Polls carried out by the Center for Sociological Research indicate that in early June a majority (54 per cent) of the adult population supported the protests, and in a later poll following the November elections, one in ten reported they had actively participated in $15 \mathrm{M}$ protest activities. ${ }^{2}$ Similar broad-spectrum mobilization and support was also a feature of the protests that occurred around the same time in Portugal and Greece. In all three countries, a profound political-economic crisis had been set in train by the financial crisis. What distinguishes Spain from these two European countries, and thus makes it a particularly interesting case for analysis, is that while events in Madrid remained at the center of media and public attention, the movement also spread to Spanish peripheral regions with longlasting anti-centralist stances. The Spanish $15 \mathrm{M}$ movement thus seemed to successfully surmount the profound social and politico-ideological divisions that have traditionally cut across Spanish politics: the left-right continuum, and the tension between centralism and regionalism.

From this perspective it is interesting to compare the Spanish $15 \mathrm{M}$ with the Israeli case, which, while less well-known, was exceptional in its scale

1 This research was funded by the Israeli Ministry of Science, Technology and Space.

2 Reports and source data are available from www.cis.es. The approval rate was defined here as those who were 'quite' or 'very' positive divided by the entire sample, including non-respondents and those uninterested in the $15 \mathrm{M}$ who were not asked their opinion. Significantly higher rates of support and participation were reported in other, smaller polls. See www.simplelogica.com and www.metroscopia.org. 
and support. What began as a small encampment of young people in Tel Aviv in mid-July 2011 protesting against the shortage and high cost of rental accommodation rapidly morphed into a social justice movement (hereafter denoted 14J, since it began on 14 July). This protest campaign dominated public and private attention for two months, gathering broad and enthusiastic endorsement. According to self-reports, one-quarter of the entire adult population participated in street protests. ${ }^{3}$ However, the economic background in Israel was much less severe than in other cases of mass protest like Greece, Portugal, and of course Spain. Prior to the protests, Israel did not experience either a collapse of its financial institutions or the threat of a sovereign debt crisis. The business cycle had been on the upswing since mid-2009, youth unemployment was moderate, and no new or controversial austerity plan was on the government's agenda (Rosenhek and Shalev 2013).

No less intriguing is the fact that in spite of the deep and fractious ideological and social divisions that characterize politics in Israel, the protest movement was remarkably consensual - even more so than in Spain. It spawned a series of unprecedented mass demonstrations that peaked on 3 September 2011 with a turnout of 400,000 - equal to the mobilization peak reached on 19 June in Spain, with a population six times that of Israel. ${ }^{4}$ Opinion polls indicate that the Israeli protest movement enjoyed extremely broad approval among the mass public (support rates of 80 per cent or more). ${ }^{5}$ Unlike in Spain, it was praised and promoted in nearly all of the major organs of the mass media and was treated with tolerance and even sympathy by most local authorities and police.

In divided societies, it is not obvious how large segments of the public come to participate in demonstrations and award a social movement such broad popular legitimacy that it (temporarily) cannot be either ignored or repressed. The puzzle motivating this paper is the fact that in both Israel and Spain, broad and consensual protests occurred in societies rent by deep sociopolitical divisions that were seemingly unrelated to the distributional issues that animated the protests. Theoretically, focusing on the effect of political cleavages on contentious mobilization contributes to established

3 The Israeli survey analyzed in this paper, carried out shortly after the protests peaked, yielded a participation rate of 24.4 per cent, compared with 25.5 per cent based on a survey by the Israel Democracy Institute in April and May the following year (Hermann et al. 2012).

4 Estimates of the number of protest participants in Israel are based on counts of mobile phone users in the relevant areas by TrendIt (http://trendit.net/en), published by all media sources and uncontested by either protest organizers or the authorities.

5 See for example www.peaceindex.org and http://truman.huji.ac.il/upload/truman_site_ poll_37_September2011(1).pdf. 
understandings of the political opportunity for protest by adding a hitherto unrecognized hindrance (the cleavage structure of institutional politics). Empirically, common denominators discovered in Spain and Israel are likely to have significant explanatory power, given the sharp contextual differences between these two settings in institutional and noninstitutional politics. The comparison may thus shed badly needed light on the recent protest wave, for which the social movement literature proved to be ill-prepared.

In analyzing the political dynamics of the two protests, we focus on their most distinctive shared characteristic: their unusually broad and cross-cutting public support. This is an intentional departure from much of the emergent research on the anti-inequality and anti-austerity protests in consolidated democracies since 2010, which has focused mainly on the sites in which the occupation of public space took place and in which innovative practices were developed (Benski et al. 2013). In some national contexts notably the Occupy Wall Street movement in the US - this narrow focus is justified because active mobilization behind the anti-inequality protests was limited mainly to the camps themselves. However, in Israel and Spain, endorsement and participation extended far beyond the occupier activists. Thus, our interest is not in the 'core militants' but in the hinterland of both passive and active supporters.

We investigate the political and ideological determinants of the success of these two movements in mobilizing mass support. Specifically, what is the relationship between individuals' sympathy for active engagement and the cleavage structure of institutional politics? Our chapter presents comparative analyses of micro-level data from public opinion polls in Spain and Israel carried out soon after the mass demonstrations peaked. The first section reviews some of the main characteristics of the protests in the two countries, not including their organizational forms. The following two sections focus first on the economic background and second on the national political context, especially institutionalized cleavages. We then discuss our hypotheses and data sources. We present our findings using three explanatory dimensions: the 'master' (left-right) political cleavage, support for redistribution, and the social cleavages relevant to each society.

\section{The Protests in Spain and Israel}

A wave of protests began in Spain in late September 2010, when trade unions called for a general strike to fight back austerity measures. In March 
2011, Spanish university students joined the mobilizational tide and also launched a strike against rising tuition fees and budget cuts in public education. A few days later, the platform Youth Without A Future (Juventud Sin Futuro) organized a demonstration against both the economic crisis and the bipartisan 'PP-PSOE partitocracy'. They described themselves as 'Homeless, jobless, pensionless, fearless'. On 14 May, a large demonstration took place in Barcelona, convened by 200 social organizations and unions fighting against welfare cuts in Catalonia (Ubasart forthcoming). In this combustible context, the call issued by the digital platform Real Democracy Now (DRY, Democracia Real $\mathrm{Ya}$ ) to take to the streets on May 15 - one week before regional and municipal elections throughout Spain - was the spark that ignited the so-called 'Indignados' mobilizations. Hundreds of thousands of people, communicating through the Internet and social media applications, took to the streets in fifty Spanish cities in the ensuing days.

Triggered by police repression and the political response to the 15 May mobilization, the original call for 'Real Democracy Now' quickly gave way to an 'Occupy the Square' movement. Mobilizations were portrayed as "apolitical" and, downplaying their heterogeneity in both socio-economic and politico-ideological terms, participants defined themselves as "persons" working together in "common matters" for the "common good" (Perugorría and Tejerina 2013b). The central movement's demands concerned electoral reform and political corruption, ending state subsidies to the Catholic Church, and finding immediate solutions to the problems of unemployment and precariousness. In its initial stages, the $15 \mathrm{M}$ movement was supported by $65-70$ per cent of the public. ${ }^{6}$ Mobilizations reached a peak on 19 June, with 250,000 people demonstrating in the streets of several Spanish cities. ${ }^{7}$ However, by mid-June the encampments were no longer sustainable due to increasing fears of repression and eviction, and they passed the torch to decentralized assemblies in urban neighborhoods, small towns, and villages. This transition was accompanied by a steep decrease in the number

6 See note 2. In another survey carried out by the Spanish Youth Institute (INJUVE) in October 2011, of the 15-29 age group, 62 per cent of interviewees had a positive opinion of the protests, 14 specific $15 \mathrm{M}$ demands were approved by the majority, and 26 per cent reported attending $15 \mathrm{M}$ mobilizations (http://www.injuve.es/observatorio/valores-actitudes-y-participacion/jovenesactitudes-sociales-y-politicas-y-movimiento-15-m). According to surveys by Metroscopia for the ElPaís newspaper, sympathy towards $15 \mathrm{M}$ declined from 64 per cent to 51 per cent between June 2011 and May 2012, but increased to 63 per cent in May 2013. (http://www.metroscopia.org/ datos-recientes/analisis-blog/item/clima-social-mayo-2013?category_id=3).

7 The figure of 250,000 protesters is the authors' conservative estimate based on information in national newspapers and from groups close to the $15 \mathrm{M}$ movement. 
of participants but also by an internationalization of the protest that soon turned the $15 \mathrm{M}$ into a beacon for similar movements around the world (see the chapter by Nez in this volume).

The Israeli 14J social justice movement emerged on 14 July 2011 as a protest against the cost of housing by a small group of students who erected tents on Rothschild Boulevard in the heart of Tel Aviv's financial district (Grinberg 2013). The 'tent protest' or 'housing protest', as it was initially called, quickly spawned a series of unprecedented mass demonstrations. The 14J movement was remarkably consensual, and it was praised and promoted by nearly all of the major organs of the mass media, including the business press. Until the protests quickly faded as summer ended, local authorities and the police adopted a tolerant or even sympathetic stance towards the tent encampments and mass demonstrations of the protest movement.

Contrary to the $15 \mathrm{M}$, the Israeli $14 \mathrm{~J}$ did not place demands on the political system. It did, however, call for the revitalization of the welfare state and for increased state support for young families. The movement adopted the deliberative and participatory democratic practices that originated in Spain but recognized the leadership of a cadre of young activists with two authoritative spokespersons. It cooperated with a wide variety of interest and cause groups, but like the $15 \mathrm{M}$ it scrupulously avoided any kind of contact or collaboration with political parties. Protest leaders consciously adopted the all-embracing slogan 'the people demand social justice'. Ironically, however, the most enthusiastic supporters and bearers of this slogan came from the ranks of the middle and upper-middle classes. They included affluent citizens who were among the winners from the neoliberal restructuring of Israel's political economy since the 1980 s but whose children found their incomes and employment conditions eroded by the longer-term effects of these very same reforms (Rosenhek and Shalev 2013).

\section{Economic Background}

In early 2011, the Spanish economy was in its third year of recession as a result of not only the worldwide financial crisis but also the bursting of a decade-long real estate bubble and the implosion of the market for mortgages. Following the lead of other developed countries, the Spanish government had taken measures to rescue vulnerable banks and to weather the socio-economic effects of the financial storm. However, as talks about Greece's potential economic bailout began to intensify, attention turned to Spain amid worries over its public deficit (6o per cent of its GDP). This 
prompted the government to backtrack and announce a slew of austerity measures.

The recession hurt most Spaniards but had a particularly severe impact on the young. Unemployment rates soared to more than 40 per cent for 20-24 year olds. Those with jobs were, however, not much better off. Many were caught in a system of temporary contracts and poorly paid, low-status jobs unrelated to the occupations for which they had been trained (Tejerina et al. 2013a). Moreover, in mid-2011 almost 70 per cent of young adults aged 18-29 still lived with their parents, thus putting further pressure on already tight family budgets and overburdened support networks.

Despite its scope and gravity, the Spanish crisis did not have the same socio-economic impact across the different Autonomous Communities. As a result, it produced diverse political reactions, either exacerbating or downplaying long-lasting regionalist sentiments. Politicians in some of the Communities governed by the People's Party (PP) called for a return of some competencies to the central state. At the same time, regionalist political leaders in Catalonia complained that federalism was 'bleeding' their budgets. The regional government enacted severe austerity measures and deferred payments to its employees, unleashing a strong anti-austerity movement that preceded and prepared the ground for the $15 \mathrm{M}$ movement.

The economic background in Israel was much less severe than in Spain. Dissatisfaction with the high cost and limited availability of housing for students and first-time home buyers was widespread, as was resentment about price rises imposed by either the government or monopolistic private corporations. Income inequality in Israel rose in the 2000s, but unlike in previous decades this was due to regressive reforms of the tax and transfer systems. The main victims of cuts in transfer entitlements were not young people, nor were they drawn from the ranks of the middle classes, in whose name the protests were mainly conducted. Rising poverty reflected a sharp deterioration in the situation of the two most vulnerable groups in Israeli society - Arab citizens (20 per cent of the population) and ultra-orthodox Haredi Jews (about 10 per cent).

On the eve of the social justice protests, the business cycle in Israel was actually on the upswing and youth unemployment was relatively modest (12 per cent). At the same time, the average real wage had been essentially stagnant for a decade, while housing prices soared. The relative incomes of young adults and families had been falling due to the declining value of assets like higher education, which had previously enabled young people to attain middle-class lifestyles (Shalev 2012). 


\section{Political Context and Institutionalized Cleavages}

Spanish politics continues to be molded by historical processes. Some elements inherited from the political culture of Francoism (including its delegitimation of some forms of protest) have proven resilient (Tejerina 2010), and the consensus forged between the major parties during the return to democracy in the late 1970 os casts persistent shadows over contemporary politics, including the continuing distrust of social movements (Tejerina 2010; Fishman 2012). Since re-democratization, politics in Spain has revolved primarily around two intersecting axes: left-right, and Spanish unionism or 'centralism' versus regionalism or 'peripheral nationalism'. Since the 1980s, two opposing parties have been hegemonic: the center-left Spanish Socialist Workers' Party (PSOE) and the right-wing People's Party (PP). Although armed separatism existed for a brief period in Catalonia, political attention has long focused on the 'Basque (armed) conflict'. In 2009, the abertzale (Basque-nationalist) left, a coalition of different social movement organizations and party formations, began a transition from a hybrid political-military strategy to a 'purely political' oppositional strategy, akin to the Irish and South African separatist causes (Perugorría 2012). As noted below, this transition had ramifications felt in the municipal elections that followed the initial protests of the $15 \mathrm{M}$ movement.

Electoral politics in Israel are a complicated mélange of parties, issues, and social groups (Arian 2005). The three main categories of parties target the Palestinian-Arab minority, the religiously observant Jews, or the majority of secular and moderately observant Jews. Parties representing the first two constituencies focus mainly on their community's needs and worldviews. In the residual category of parties, which is the largest, the two main rivals were traditionally Labor on the left and Likud on the right. Historically, Labor defined itself as social-democratic and Likud as economically liberal, but the primary axis of contention in Israeli politics since the 1967 war has been whether to trade territories occupied in that war for peace. Over the last several decades, Likud has been the indispensable party of government, usually in coalition with nationalist and clerical parties. The left bloc - comprising the Labor Party and its closest allies - has steadily lost ground to a succession of ephemeral center parties, as its peacemaking strategy was increasingly discredited. Efforts to revive the party by adopting a social-democratic agenda have largely failed.

If we were to characterize party supporters in the Jewish population by their issue positions on the role of territorial aspirations, the use of military force, the rights of Palestinian citizens, and the role of religion in 
public life, they would be positioned on a roughly uni-dimensional left-right spectrum. In contrast, positions on social and economic issues tend to be consensual, since most Israelis would prefer a less unequal society (Shalev and Levy 2005; Shalev 2007). Parallel in part to the Spanish situation, 'tribal' collective identities institutionalized in Israeli politics have long served as a structural barrier to class-based demands for redistribution. The main divisions structuring ideology and partisanship are based on nationality, country of origin, or religiosity. At the same time, a vigorous arena of distributive politics flourishes alongside or outside of political parties, based on pressure groups, unions, NGOs, and others who lobby, bargain, and protest vis-à-vis the government, parliament and state bureaucracies. Contentious politics are a ubiquitous feature of this menu, but like party politics they are sectoral in character. For all these reasons, the mass popular protest that emerged in the summer of 2011 was highly unexpected.

\section{Rationale, Hypotheses, and Data}

Although public opinion in Spain and Israel was not entirely consensual, the majority of Spaniards and Israelis were supportive of the $15 \mathrm{M}$ and 14J movements, and among those who were not, lack of enthusiasm was more common than outright opposition. Still, the majority of the public stayed at home during even the largest demonstrations. How may these variations in passive and active support be explained? Our theoretical claim is that, in contrast to contentious political action resting on a narrower and therefore more homogenous support base, in order to explain support for or engagement in protests as broad as those observed in Spain and Israel it is essential to focus on the role of politicized social and ideological cleavages. By definition, movements with broad public support are at least partially successful in breaching boundaries created by solidarities generated by class, place, ethnicity, religion, and cultural habitus. Such divisions are even less permeable when they already play an established role as political cleavages in the institutional sphere of mass politics, along with ideological divisions that have crystallized in the same sphere.

Israel and Spain are especially suitable cases for examining the relevance of the cleavage structure of institutional politics to non-institutional mobilization because they represent 'least likely' conditions for our hypothesis to be vindicated. The contention waged by the $15 \mathrm{M}$ and $14 \mathrm{~J}$ movements focused on 'non-partisan' issues of economic justice and the responsiveness of the political system, whereas the key social and ideological divisions that divide parties and voters in the electoral politics of both countries 
ostensibly belong to unrelated domains. Precisely because many of the core social divisions and issues of 'normal' politics in Israel and Spain are seemingly orthogonal to the questions of equality, redistribution, and the economic and social role of the state that were so central to the protests, their emergence is even more puzzling. If it can be shown that factors like nationalism and religiosity structured individual engagement in $15 \mathrm{M}$ and $14 \mathrm{~J}$, this would be a strong indication of the power of political ideologies and politicized social divisions to structure mass support for extensive protests.

Substantively, we expect ideological and social cleavages embedded in institutional politics to help predict who participates in protest activities and who remains outside, and among outsiders, to help explain different levels of passive support. However, the role of institutionalized divisions is not the same for passive and active engagement. As a political performance in a public space, the mass demonstration renders social divisions and partisan loyalties potentially more salient than in the context of passive support. As Klandermans (1997) has pointed out, when protest organizations or activists seek to mobilize the members of groups with socio-cultural or socio-political loyalties and identities that differ from those of the leaders, activists, and core supporters of a social movement, even individuals who sympathize with the movement's grievances and demands may refrain from openly joining its mobilizations.

To identify connections between the cleavage structure of institutional politics and individual engagement with the protests that took place in Israel and Spain, we rely on nationally-representative public opinion polls. These polls asked respondents about both their sympathy and their active participation in the protests. (In Israel, the relevant question asked specifically about demonstrations; in Spain, it also included participation in camps or marches as well as demonstrations). The Spanish survey was carried out in November-December 2011, after the last of the mass protests on 15 October; and the Israeli one in the third week of September 2011, after the climactic 3 September demonstration. The Spanish poll has a large sample (over 60oo) while the Israeli sample included just over 1,0oo respondents, which is typical of opinion polls in that country. ${ }^{8}$

8 For details on the Spanish CIS survey (Study No. 2920) see http://www.cis.es/cis/opencm/ EN/1_encuestas/estudios/ver.jsp?estudio=12604. The Israeli poll was a national sample survey carried out by the Smith Institute for the Taub Center for Social Policy Research in Israel during the third week of September 2011. 


\section{Findings}

We begin by presenting responses to the questions on passive support and active participation that are the basis for our analysis (Table 4.1). Looking first at passive support, while respondents were offered different options in the Spanish and Israeli surveys, it is clear that the protests were much more broadly supported in Israel. Only 8 per cent of the sample expressed opposition to 14J, and a majority chose the strongest category of support. In Spain, however, nearly half (47 per cent) of the respondents ranked their sympathy for $15 \mathrm{M}$ at or below the perceived midpoint of the support scale. Moreover, just over one-tenth reported that they were not familiar with the movement (and accordingly were not asked about either passive or active support). In what follows, because the Israeli response pattern is so positively skewed, we focus on explaining variation in whether or not respondents 'strongly supported' the protests in their country. For Spain, 'strong support' is operationalized as the top 4 ranks of the original 11-point scale.

Regarding active participation, the overall rate was more than twice as high in Israel than in Spain (24 per cent vs. 11 per cent). Although active participation in both countries was highly correlated with passive support, not only strong supporters took to the streets. This may reflect a time inconsistency problem - respondents were asked about their support of the protests after they had peaked but were reporting on active participation that would have occurred while the demonstrations were still in full swing.

\section{The 'Master' Political Cleavage: Left-Right Polarization}

In contextualizing our two country cases, it was emphasized that in the institutional political arena of both countries the left-right axis both summarizes and symbolically represents the ideological domain of institutional politics. The issue positions of individuals, social sectors, and political parties can all be parsimoniously described on this axis. Yet the content of left-right variation differs substantially between the two contexts, and in each of them it is made up of several different layers of meaning. In general, the left-right division refers to both the 'old' tension between economic liberalism and support for the welfare state, and the 'new' tension between authoritarianism and a pro-growth orientation versus libertarianism and a pro-green orientation. As noted, however, in Israel these issues are weakly articulated by most political parties and do not form the basis for left/right 
Table 4.1 Passive and active participation in the Israeli 14J and Spanish 15M movements

\begin{tabular}{|c|c|c|}
\hline \multicolumn{3}{|c|}{ ISRAEL: “To what extent do you support the social protest?" } \\
\hline & Distribution of responses & $\begin{array}{l}\text { Proportion attending a } \\
\text { demonstration }\end{array}$ \\
\hline Strongly support & $56 \%$ & $37 \%$ \\
\hline Support & $29 \%$ & $12 \%$ \\
\hline Oppose & $5 \%$ & $0 \%$ \\
\hline Strongly oppose & $3 \%$ & $0 \%$ \\
\hline Not sure & $5 \%$ & $3 \%$ \\
\hline No reply & $1 \%$ & - \\
\hline Total & $100 \%$ & $24 \%$ \\
\hline \multicolumn{3}{|c|}{$(n=1,005)$} \\
\hline \multicolumn{3}{|c|}{ SPAIN: “To what extent do you sympathize with the $15 \mathrm{M}$ movement or 'Indignados'?' } \\
\hline & Distribution of responses & $\begin{array}{l}\text { Proportion attending a } \\
\text { demonstration }\end{array}$ \\
\hline Full sympathy-8 & $12 \%$ & $32 \%$ \\
\hline 7 & $10 \%$ & $22 \%$ \\
\hline 6 & $11 \%$ & $16 \%$ \\
\hline 5 & $8 \%$ & $9 \%$ \\
\hline 4 & $18 \%$ & $4 \%$ \\
\hline 3 & $10 \%$ & $5 \%$ \\
\hline 2 & $9 \%$ & $1 \%$ \\
\hline No sympathy-1 & $10 \%$ & $1 \%$ \\
\hline Unfamiliar / haven't heard & $11 \%$ & - \\
\hline No reply & $4 \%$ & - \\
\hline Total & $100 \%$ & $11 \%$ \\
\hline & $(n=6,082)$ & \\
\hline
\end{tabular}

Note: In Spain the original 11-point scale of passive support was collapsed into 8 levels, and the question regarding active support asked whether the respondent had attended a demonstration or participated in an encampment, march or protest.

identification, which instead rests mainly on positions regarding territorial, military, and religious issues that are specific to the Israeli context.

In Spain it is also true - though to a lesser extent - that left and right serve as political markers for 'non-standard' beliefs and issue positions. Their meaning is linked to local conflicts that emerged in several historically 
profound rounds of contention over state authority. The transition from Francoism to democracy three decades ago raised or amplified what continue to be contested issues concerning arrangements for recognizing and accommodating diversity between regions. These issues are partly embodied in the left-right dimension, as well as having their own ideological discourses based on demands for national recognition and/or local autonomy.

Against this background, it is of considerable interest to ask how far support and participation in the protests of 2011 followed the left-right division. Since political economy and redistribution are central to the left-right cleavage in Spain but not in Israel, we expect polarization around this cleavage to be more marked in the Spanish case. However, there is also a temporal dynamic to consider. A protest may enjoy widespread legitimacy at the initial moment of emergence, but after the first flash of enthusiasm dies down it may align more closely with familiar political divisions. Accordingly, for each country Figure 4.1 presents the results of an initial poll carried out only a few weeks after the protests broke out, compared to a later one. In Israel, the second survey was fielded only a month after the first, while in Spain it was six months later. To maximize comparability, the proportion strongly supporting the protests was recalculated for each survey as a ratio, relative to the mean for all respondents.

Figure 4.1 Proportion of strong supporters relative to the mean, according to left-right position

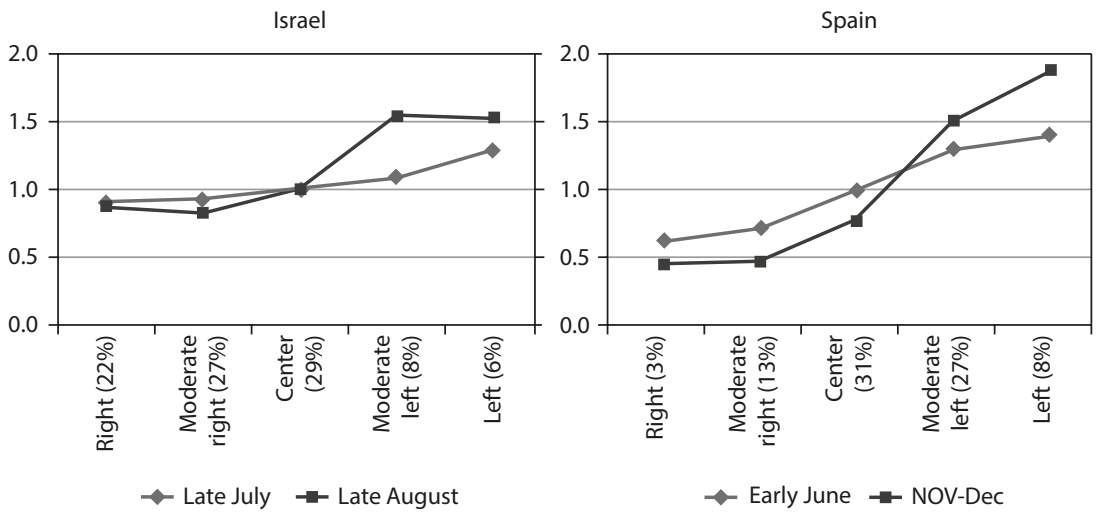

The findings for both countries support both of our expectations. The position of individuals on the left-right dimension is associated with support for 
the protests in both countries but substantially more in Spain than Israel. Furthermore, there is clear evidence of growing polarization over time.

In addition to the overall role of the left-right cleavage - the contrasts between the two countries and at two points in time - we are able to compare the impact of this political division on two different types of engagement: passive support and active participation. Here, differences between the two countries are best discerned by juxtaposing them on the same graph and measuring absolute rather than relative rates of engagement. It appears from Figure 4.2 that citizen involvement was more cross-cutting in Israel than in Spain. In Spain, individuals well to the left were almost as likely as their Israeli counterparts to support and participate in the protests - but the differences between the two countries become sharper when attention shifts to the center and right.

Figure 4.2 Two types of engagement in protest, by left-right ideology

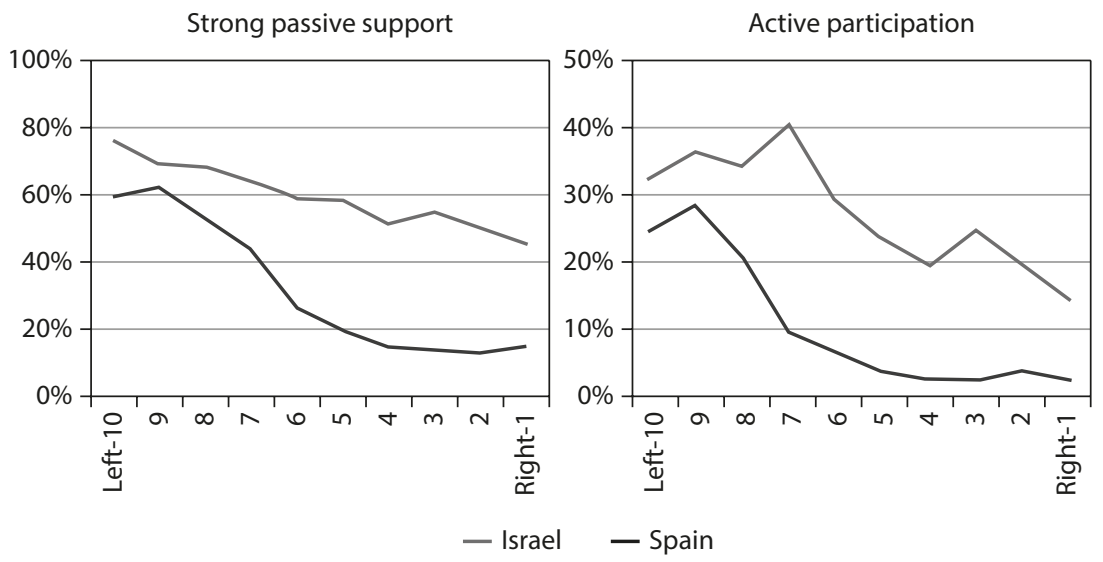

Table 4.2 Cross-country difference in left-right polarization

\begin{tabular}{lcc}
\hline & Spain & Israel \\
\hline Passive support & 4.4 & 1.5 \\
Active participation & 7.7 & 2.0 \\
\hline
\end{tabular}

Note: Polarization is measured as the ratio of the proportion engaged in the two most leftist categories in comparison with the two most rightist ones.

The cross-country difference in the left-right gradient can be conveyed by a simple measure of polarization: the ratio of the proportion engaged in the two most leftist categories in comparison with the two most rightist 
ones (see Table 4.2). The results highlight not only the greater intensity of political polarization in Spain but also the fact that in both countries - but again, especially in Spain - the left-right division matters more for active than passive engagement.

It should be noted that the ultimate impact of polarization on aggregate support was muted in Spain by the distribution of the population along the left-right spectrum. Whereas in Israel fewer than 30 per cent of passive supporters and 15 per cent of active participants placed themselves in the top 4 categories of the leftism scale, in Spain the parallel proportions were two-thirds and three-quarters respectively. Hence, lack of enthusiasm for the protests on the right had less of an overall impact in Spain than in Israel.

\section{Commitment to Redistribution}

As has already been emphasized, in Israel the content of the left-right cleavage concerns issues of identity and foreign policy that are seemingly irrelevant to the 14J, framed as a movement committed to social justice. Indeed, we expected attitudes towards government efforts to reduce inequality via redistribution to be closely related to engagement in the Israeli protest. Since the $15 \mathrm{M}$ movement addressed a wider range of issues including the deteriorating prospects of youth, government corruption and non-responsiveness, and opposition to austerity - we assumed that in the Spanish context, attitudes to redistribution would be less closely linked to protest involvement. Figure 4.3 confirms these expectations. Both forms of engagement in mass protest were more strongly linked in Israel to views on the welfare state than in Spain. ${ }^{9}$ Measuring polarization in the same manner as before, we find that in relation to both passive and active involvement it was about 60 per cent higher in Israel than in Spain (Table 4.3).

Thus, whereas in Israel engagement in protest was more responsive to redistribution than to leftism, the profound role of leftism in Spain in selecting protest supporters and activists was evidently due to something more than the tension between social democracy and free-market liberalism. The left-right cleavage in Spain also overlaps in part with social cleavages that are key drivers of political behavior - the conflict over regionalism

9 In Israel, support for redistribution is measured by combining responses to two questions: one asked whether the government should reduce income inequality, the other asked respondents to choose their most important policy priority from a list that included "reducing poverty and inequality". In Spain, the relevant question offered an 11-point scale tapping agreement with the view that the government should spend more on benefits and social services even though this would mandate higher taxes. In both cases, we compacted responses into a 5-point scale. 
Figure 4.3 Two types of engagement in protest, by attitude towards redistribution

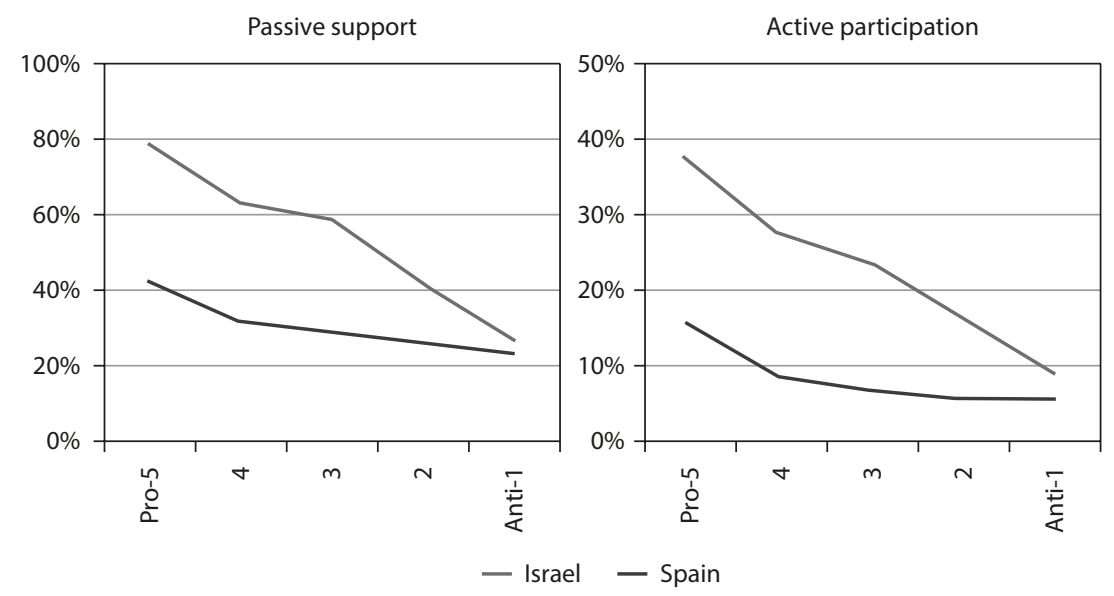

Table 4.3 Cross-country difference in polarization regarding redistribution

\begin{tabular}{lcc}
\hline & Spain & Israel \\
\hline Passive support & 1.8 & 2.9 \\
Active participation & 2.7 & 4.2 \\
\hline
\end{tabular}

Note: Polarization is measured as the ratio between the top and bottom categories.

versus centralism, and the religious cleavage. Figure 4.4 shows that all three variables are clearly associated with left-right positions. As we shall now see, such overlaps play an important role in understanding the politics of protest involvement.

\section{Figure 4.4 Correlates of the left-right cleavage in Spain}
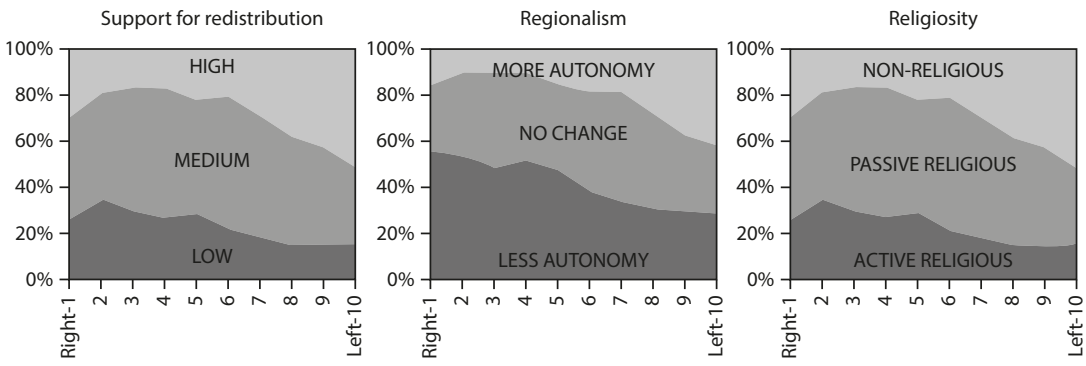


\section{Politicized Social Cleavages}

In both Israel and Spain, conflicts over issues of social and economic justice like those raised in the $15 \mathrm{M}$ and $14 \mathrm{~J}$ protests are directly or indirectly linked to social divisions along ethnic, religious, or regional lines. The politicization of such social cleavages results from both group differences in culture and interests, and historical alliances, co-optations, and animosities between parties and groups. Hence, group membership not only represents a potential prior influence on individual orientations that may have influenced support for the protests under study here, but may also embody group-level interests and loyalties that are at least as relevant.

To illustrate this point concretely, consider the alienation of Israel's ultraorthodox population from the $14 \mathrm{~J}$ movement. Given the high incidence of poverty among ultra-orthodox Jews, the social justice movement with its critique of rising inequality and focus on the need to revive and enlarge Israel's welfare state might have garnered considerable sympathy and support from this sector of the population. Two factors prevented this from happening: the deep cultural divide between the ultra-orthodox and the educated, secular, and Tel Aviv-based core of the protest movement, and the specific way in which the ultra-orthodox communities of Israel have been incorporated into institutional politics by 'sectoral' political parties. These parties routinely participate in government coalitions that enable them to target state-supplied or state-subsidized services and benefits to their constituents. Fear of jeopardizing this system of redistribution sowed suspicion and reluctance among both their leaders and supporters. At the same time, non-orthodox Israelis deeply resent the benefits won by ultra-orthodox politicians for their constituents.

Bearing in mind the ideological, ethnic, and religious cleavages just noted, we evaluate the effect of institutionalized political cleavages on citizen engagement in the $14 \mathrm{~J}$ protests by distinguishing six distinct sociopolitical blocs or 'tribes'. In addition to the Arab-Jewish cleavage, our typology relates to the only measurable ethnic division among Jews, ${ }^{10}$ that between veterans and 'Russians' (immigrants from the Former Soviet Union, FSU), as well as to the religious and left-right cleavages. Unfortunately, it is not feasible to distinguish between 'hardcore' ultra-orthodox Jews and 'modern' observant Jews; hence both are aggregated here under

10 Measuring the longstanding division between Jewish immigrants (or their descendants) from Arab countries and those who originated in Europe requires information on the origin of grandparents which was not available in the survey analyzed here. 
the 'religious' umbrella. We also aggregated 'traditional' and 'secular' Jews (other than Russians) into a single 'non-religious' category, since in any event this distinction had no significant impact on protest support. Finally, note that since 75 to 8 o per cent of both Russian immigrants and religious Jews identify with the right, other members of these two groups are not included in this analysis.

Figure 4.5 Passive and active support for the Israeli protests by sociopolitical bloc

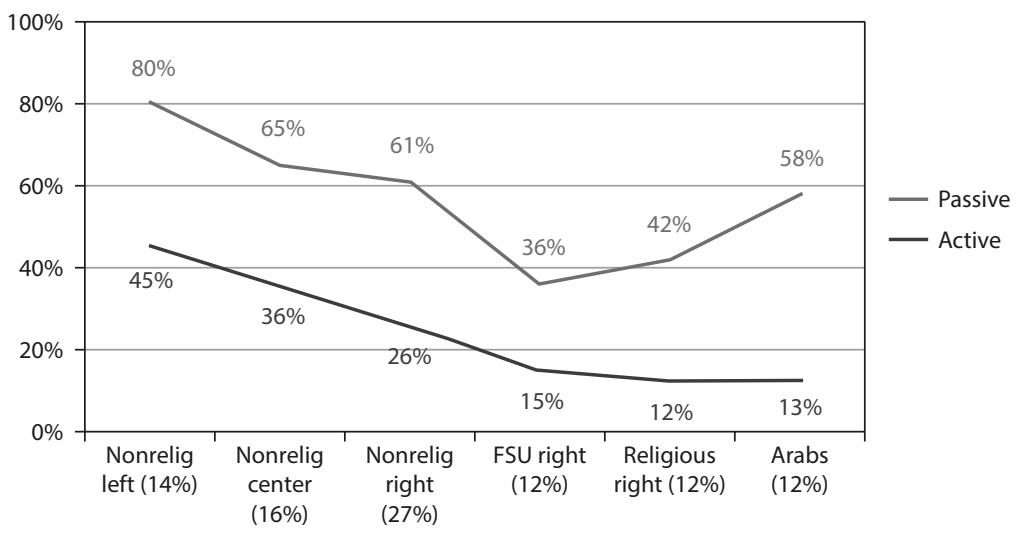

The findings in Figure 4.5 make it evident that the high rates of aggregate support for the Israeli protests conceal considerable divergence between different sociopolitical blocs, and that this divergence is especially marked for active participation. The strongest support and active involvement came from nonreligious, non-immigrant Jewish Israelis who identify with the left. Compared to immigrants from the FSU and observant veteran Jews - both of whom identify with the political right - members of this group were twice as likely to be strong passive supporters and three times as likely to have participated in a demonstration. Among the majority (57 per cent) who defined themselves as non-religious Jews, both types of support were clearly associated with the left-right division. Finally, Palestinian-Arab citizens exhibited a unique pattern of relatively high passive but low active engagement. As a marginalized minority, the Arabs in Israel could hardly be unsympathetic to the protestors' call for social justice, but given the deep social and political gulf between Arabs and Jews (as well as a high degree of spatial segregation), they were less amenable to and available for performative political action on a broad Jewish-Arab front.

Given the prevalence of economic disadvantage among Arabs, ultraorthodox Jews, and part of the FSU immigrant community, it is clear that 
collective political loyalties were capable of overriding the role of economic concerns in shaping the orientation of different social groups to the protests. This tendency notwithstanding, it is still possible that individual-level variation within the groups is at least partly explained by material concerns. To investigate this possibility, we constructed an indicator of 'fear of future economic distress' from two questions asked in the Israeli survey. ${ }^{11}$ More than one in six of the individuals polled indicated that they were seriously in fear of future economic difficulty. Figure 4.6 shows that, except among Russian immigrants, such anxiety exercised a palpable effect on individual-level variation in passive support for the $14 \mathrm{~J}$ protests within each sociopolitical 'tribe'.

\section{Figure 4.6 Passive support for the Israeli protests by sociopolitical bloc and fear of future economic distress}

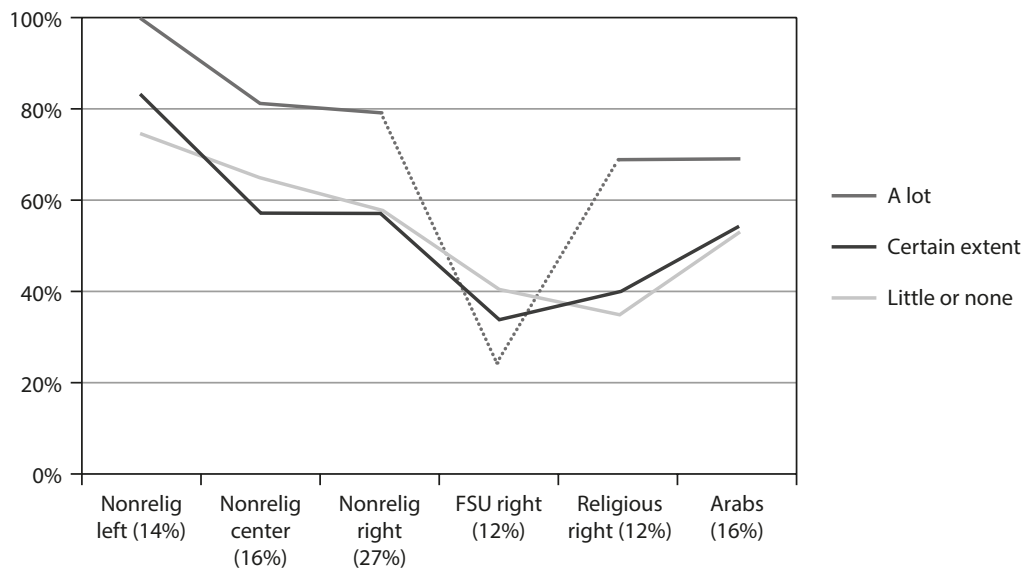

Turning now to the impact of politicized social cleavages in Spain, the present section reports findings for the effects of religion and regionalism, connecting them as in Israel to the left-right cleavage. On the face of it, the political role of religion is unlikely to be significant since, in line with the majority of Europeans, only 15 per cent of Spaniards regularly attend religious services (Center for Sociological Research 2009). Nevertheless, Calvo and colleagues have shown that religious voting can be important even when large sectors of the population feel indifferent to religion

11 The indicator summed responses to the following questions: "Do you fear that you or your family could find yourself in poverty or economic distress in the next 2-3 years?" and "Do you or anyone in your family fear being unemployed due to layoffs or difficulty in finding a job?" 
(Calvo and Montero 2002; Calvo 2009; Calvo et al. 2010). During the 1980s, the widespread perception of Alianza Popular (AP) as an extremist and conservative party brought sizeable number of Catholics to vote for the center-leftist PSOE. However, after its transformation into the Partido Popular (PP) in 1989, the party allowed Catholic voters to overcome the obstacles that had prevented them from voting for the PP. As a consequence, by the mid-199os religious voting recovered notably, associated with a sharpening of the religious profiles of the other major Spanish parties (Montero et al. 2008).

Religious voting peaked in the mid-20oos, tied to an unusual level of confrontation between the Socialist government and the Catholic Church. The 2004-2008 agenda of the PSOE government implied controversial and simultaneous changes on various fronts: the civil rights of sexual minorities, the role of religion in the educational curriculum, bioethics, women's rights, and the recovery of the 'historical memory' of the Franco years. The resulting conflict with the moral order defended by the Spanish Catholic Church had a clear effect on voting in the general elections held in March of 2008. In this election, the religious cleavage in Spain was most salient to voters who did not identify ideologically with the left, and had the strongest impact on support for the PP (Calvo et al. 2010). This suggests the importance for our purposes of assessing the joint effect of the left-right and religious-secular cleavages on mass mobilization in the $15 \mathrm{M}$ protests.

It is worth noting that in the specific case of the $15 \mathrm{M}$ movement, political conflict over religion explicitly spilled over into contentious politics. Among other demands, the $15 \mathrm{M}$ protestors called for the 'real decoupling' of the state and the Catholic Church. Coinciding with the world summit of Catholic Youth in Madrid and the Pope's visit to Spain, in mid-August 2011 the $15 \mathrm{M}$ Working Group on the Economy obtained consensus for a detailed proposal for eliminating tax collection and various state subsidies targeted to the Catholic Church and its allied institutions..$^{12}$ This confrontational move presumably increased the salience of the religious cleavage for $15 \mathrm{M}$ support, especially (in light of our earlier theory) for performative (active) engagement.

For the purpose of our empirical analysis, we distinguish three broad categories of religious identification and observance in Spain. 'Non-religious'

12 Sources: http://madrid.tomalaplaza.net/2011/08/17/propuesta-abierta-consensuada-porel-grupo-de-trabajo-de-economia-sobre-financiacion-de-la-iglesia/; Retrieved 3 February 2013 from http://www.2ominutos.es/noticia/1428422/o/logros-conseguidos/pendientes-ideario/ movimiento-15m. 
respondents (about one-quarter of the total but nearly 40 per cent of those aged under 35) have no stated religion or are atheists. The 'passive religious' identify as Catholics or with some other religion but hardly ever attend services, while 'active religious' attend at least several times a year (roughly one-third of the total and two-thirds of those over 65).

Figure 4.7 The joint effects of religiosity and leftism on support and participation in the Spanish 15M protests

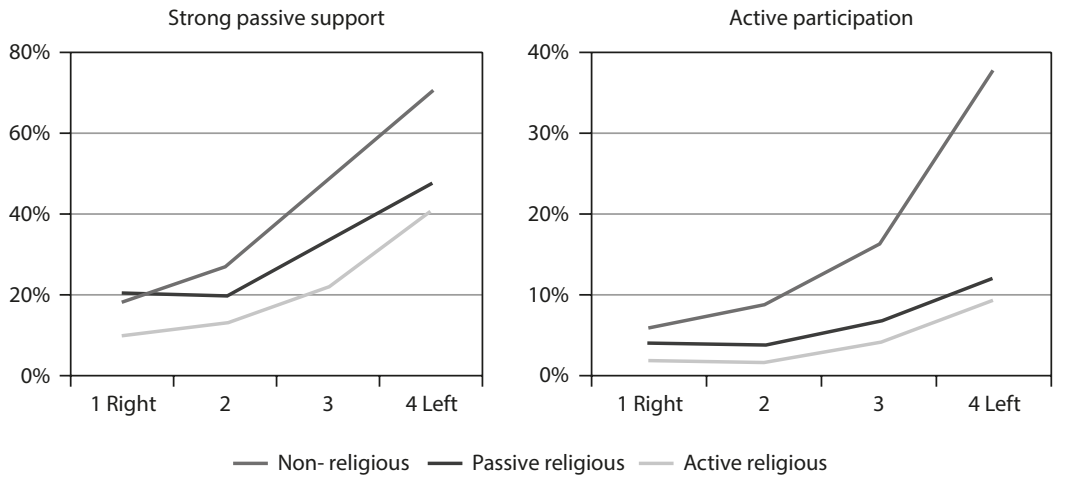

For two reasons, it is essential to analyze the effects of religiosity and political ideology jointly. First, the overlap between the two variables implies a risk of overestimating the impact of religion analyzed alone. At the same time, this overlap is only partial. Some non-religious and actively religious respondents have the 'wrong' orientation (Figure 4.4). In fact, at least half of the members of both groups position themselves in intermediate categories of the left-right scale. Consequently, it is not surprising to find (Figure 4.7) that religiosity has a substantial independent effect on involvement in the $15 \mathrm{M}$ demonstrations, net of an individual's placement on the left-right continuum (and also, as will be shown later in the multivariate analysis, net of other determinants). Both passive and active engagements in the $15 \mathrm{M}$ movement were restrained among those oriented towards religion. The most visible effect, except for those definitively loyal to the right, is the difference between secular Spaniards (the largest category) and all others.

A second reason for jointly analyzing the effects of the left-right and religious-secular cleavages is that studies of electoral behavior show that their effects are interactive (Calvo et al. 2010). Our results show an interaction that is especially pronounced for active participation in the $15 \mathrm{M}$ protests. Religiosity weakened the tendency of engagement to rise along 
with leftism. Put differently, secular leftists were 'free' to be drawn into the protests to a degree that more religious leftists were not. ${ }^{13}$

\section{Figure 4.8 The joint effects of regional identity and leftism on support and participation in the $15 \mathrm{M}$ demonstrations}

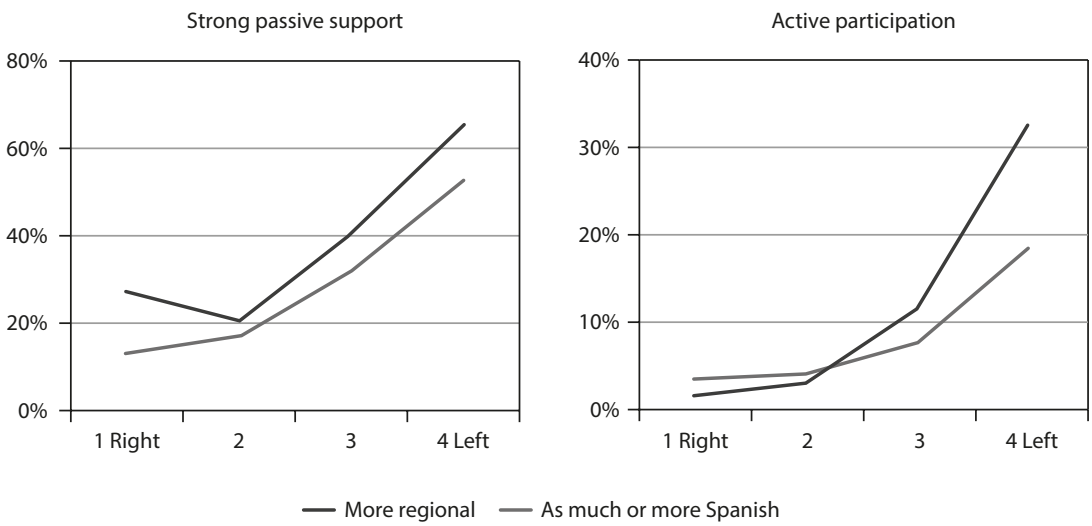

Similar findings emerge when examining the regional cleavage in Spain, which we have argued has both an identity dimension (based in some cases on ethnicity) and a political-institutional one. Figure 4.8 shows that while identifying with one's region had only a modest relationship with passive support, it substantially amplified the role of leftism in mobilizing citizens to actively participate in the protests.

\section{Multivariate Analysis}

The findings reviewed provide strong indications that ideological and social cleavages shaped engagement in both the Spanish and Israeli protests. However, an obvious question is whether the bivariate and trivariate relationships analyzed would hold up in a multivariate analysis. The purpose of such an analysis is to evaluate net effects, not only by holding constant the other key explanatory variables that we have reviewed so far but also by adding controls for other factors that are not of particular interest for our theoretical agenda but could plausibly have explanatory power.

13 Interestingly, these are not the same interactions that Calvo and colleagues (2010, Figs 3 \&

4) found in their study of voting for the two main parties in Spain's 2008 elections. 
Before turning to the results, it should be emphasized that we do not regard the multiple regressions that follow as an empirical test of a wellspecified theoretical model. Rather, the purpose is to test the robustness of previously-examined bivariate relationships and to obtain estimates of the relative weight of different predictors and the extent to which they are similar for both the two outcomes and the two country cases. We ignore possible interaction effects, including some that have already been documented in the previous exploratory analysis, because this would complicate and overtax the model.

The key explanatory variables for both countries include the left-right cleavage, attitudes towards redistribution, and the social cleavage (religion) which is common to both countries. For Israel, the model also includes a dummy variable for respondents from the Former Soviet Union. For Spain, we add two measures of the regional cleavage, one tapping collective identity and the other the desired level of local autonomy, as well as dummy variables for the two most important centers of regional nationalism (Catalonia and the Basque Country). A third binary variable is intended to capture any net impact of Madrid, the Autonomous Community that hosts the three branches of the central government and was the epicenter of the $15 \mathrm{M}$ movement.

The control variables included in all models are: (a) age, on the grounds that the protests were clearly dominated by, and mainly oriented towards, young people and that older persons might have faced greater technical difficulties and anxiety about participating in demonstrations; (b) gender, given the prominence of women in the leadership and activist core of the Israeli movement; (c) education, since students played a central role as activists and supporters of these movements, and complaints by the Spanish 'youth without a future' were often linked to the shortage of (good) jobs for university graduates; and (d) variables measuring the degree to which respondents felt they were under economic pressure and, in Israel, dummy variables to represent the north and south of the country, where economic opportunities are generally inferior to those in the center.

For each country, separate regressions were estimated for passive and active engagement. The models for both were identical, except that the one predicting active engagement includes passive support as an independent variable. The reason is that in relation to active participation, our interest is in explaining what turns sympathy into action. The question at hand is therefore how any given factor (e.g. leftism) affects the propensity to take an active role in the protests, beyond its contribution to understanding individual differences in passive support. Note that for Israel the multivariate 
analysis does not include Arab respondents. The political and ideological affiliations of the Arab minority and its internal cleavages differ substantially from those of the Jewish majority, and the size of the Arab sample is insufficient to permit separate analysis.

Figure 4.9 OLS regressions predicting high passive support or active participation in the $15 \mathrm{M}$ and $14 \mathrm{~J}$ protests

SPAIN - PASSIVE SUPPORT

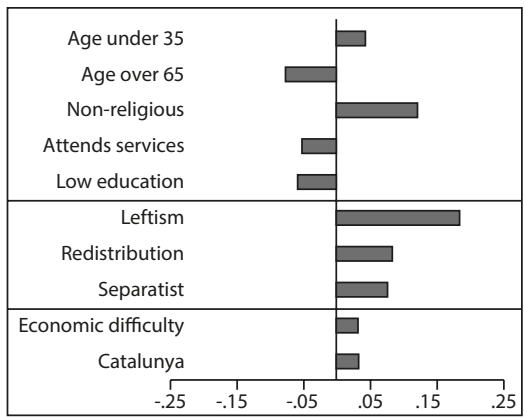

ISRAEL - PASSIVE SUPPORT

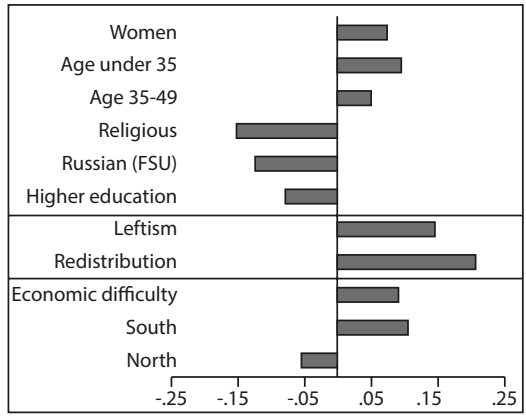

SPAIN - ACTIVE PARTICIPATION

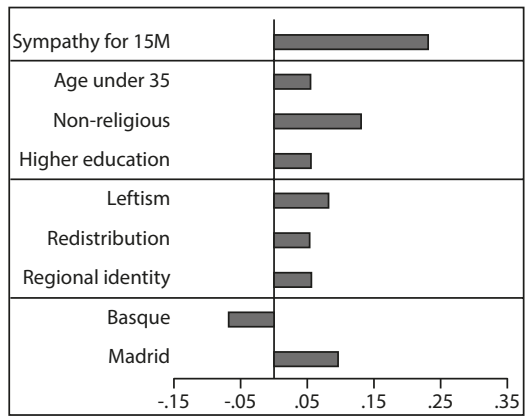

ISRAEL - ACTIVE PARTICIPATION

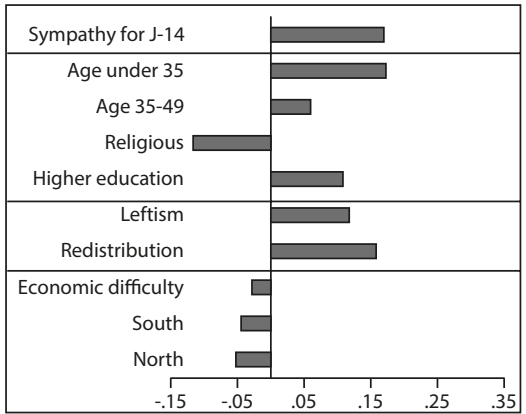

The charts in Figure 4.9 are designed to ease the task of comparing the four different sets of results. To facilitate comparability within and across regressions, they present standardized (beta) coefficients but only those that were statistically significant (t-statistic of at least 2). Note that since both dependent variables are binary, a case could be made for estimation using logistic regression, but we opted for the simpler and more intuitive OLS approach. The full results of the regressions are available on request.

We begin with the two charts for passive support. Before noting specific highlights of these results, it is worth pointing out that the set of independent variables with significant net effects, and the size and direction of these effects, are broadly similar between the two countries. In both countries 
leftism, support for redistribution, and the religious cleavage have the most impact on whether individuals expressed strong sympathy for the protests. In Israel, consistent with the weaker connection between the meaning of the left-right cleavage and distributional issues than in Spain, attitudes towards redistribution are a stronger predictor of passive support than left-right position. Another noteworthy difference is that whereas both a direct indicator of economic distress and one of the regional indicators have substantial effects in Israel, the relevant variable for Spain has little impact.

So far as country-specific predictors are concerned, as expected Israelis who immigrated from the Former Soviet Union were substantially less sympathetic to the $14 \mathrm{~J}$ movement. In Spain, also not surprisingly, individual support for regionalism plays a role, but only as measured by support for institutional separatism. However, no additional effect is found for the dummy variables for Catalonia and the Basque Country. Although respondents in Catalonia were a bit more sympathetic than the average respondent, it appears that the distinctiveness of these two regions is mainly accounted for by other individual-level variables included in the model (such as separatism and leftism). Lastly, only in Israel were women more likely to sympathize with the protests than men.

Turning to the findings for active participation, in both countries the young, leftists, the secular, the educated, and egalitarians were the most likely to turn sympathy into active engagement. But except for the religious cleavage, all of these effects were notably stronger in Israel. The most obvious difference between the two countries is that in Spain more of the variation in whether individuals took to the streets is explained by their degree of sympathy. In addition, in Israel differences in age and ideology contributed much more than in Spain to the residual variation in active participation.

Only in Israel do we find that indicators of economic distress influenced protest participation. Although the observed effects are weak, it is interesting to note a significant shift in their direction as we move from passive to active engagement. Net of differences in ideology and social cleavages, more advantaged Israelis (those with a higher education) were less likely to strongly support the protests - but at any given level of support, they were more likely to participate.

Finally, Spanish regionalism has interesting effects on active engagement. Individuals expressing regional nationalism (as indicated by their primary identity) were somewhat more likely to participate. However, the net effects of the regional dummy variables show that in the nationalist Basque Country the propensity for active engagement in the $15 \mathrm{M}$ protests was below average. The second finding confirms our suggestion that for 
Basques, the pressing regional-political agenda at the onset of the $15 \mathrm{M}$ movement had the effect of crowding out their propensity to take to the streets on behalf of an 'outside' movement.

$$
* * *
$$

Can social movements in divided societies win broad support and inspire large-scale participation? Our paper has analyzed two extensive and consensual protests that took place amidst the 2011-2012 international cycle of anti-inequality protests - the Israeli 14J and Spanish $15 \mathrm{M}$ movements. We have characterized these movements as having broad and cross-cutting public support and have aimed to unveil their limitations as well as success in breaching politicized social and ideological boundaries. Our theoretical claim is that, in contrast to contentious political action that rests on a socially and politically homogenous base, in order to explain support for such extensive protests it is essential to focus on the cleavage structure of institutional politics. While central to the study of mass electoral politics, the role of political cleavages has not previously been addressed as one of the features of the institutional political system that may either facilitate or impede contentious collective action.

Given the lack of prior theoretical guidance regarding the role of institutionalized political cleavages in structuring engagement in non-institutional political action, our research is exploratory and aims to contribute to the development of empirically grounded and inspired theoretical insights. Two features of the design of the research have facilitated this endeavor: the contrast between two different levels of engagement (passive and active), and the comparison between two different national contexts. The protests occurring in Israel and Spain both featured mass mobilizations and broad popular support (dependent variable), and the two countries also share institutional political systems that are rent by social and ideological cleavages dividing parties and voters in electoral politics (independent variable). Moreover, in both contexts these cleavages belong to domains that are nominally unrelated to the core issues of distributive justice and political accountability raised by the protesters. Hence, we have suggested that Spain and Israel are ideal showcases for uncovering the role that social and ideological divisions entrenched in 'conventional' politics may play in the patterning of group and individual engagement in 'unconventional' political action.

Our empirical findings are based on micro-data from parallel public opinion polls conducted in 2011 in Spain and Israel after the protests peaked. We began with an analysis of the impact of the 'master' left-right cleavage, 
showing that in both countries support and participation in the protests were considerably stronger among citizens on the left and weaker among those on the right, especially in relation to active engagement. However, there are also quantitative and qualitative differences between the two countries, particularly in the likelihood of respondents identifying with the political right or center participating actively in the protests. Consistent with the greater centrality of social and economic issues to the meaning of left and right in Spain, we find stronger ideological polarization of supporters there than in Israel. At the same time, and for the same reason, both passive and active forms of support were more strongly linked to views on redistribution in Israel than in Spain.

Although politicized social cleavages are partly embodied in the left-right divide, our multivariate statistical analysis confirmed that they also had substantial effects in their own right on the structuring of engagement in the $15 \mathrm{M}$ and $14 \mathrm{~J}$ protests. At the same time, we also found evidence of interactive effects of ideological and social divisions. For example, although clearly located on the political left, Israel's Palestinian-Arab citizens combined relatively high passive support with low active participation. In Spain, we found that religious affiliation and observance restrained the propensity of those on the left to play an active part in the $15 \mathrm{M}$ movement, whereas being secular or having a primarily regional identity had the opposite effect. These kinds of interactions suggest that future research would benefit from the use of configurational methods and that the weight of different determinants of engagement in protest cannot be accurately assessed by means of a regression model that includes only main effects. Nevertheless, the key findings of our multivariate analysis are clear and important: the 'gross' bivariate effects presented in the exploratory results also show up as 'net' effects in a multivariate model; and in the two countries, both political ideology and politicized social cleavages matter.

Differences in the results of the Spanish and Israeli regressions are particularly interesting as far as active participants are concerned. Israeli protesters tended to be young (under 35), secular, university-educated, and living in the relatively affluent center of the country, and they were both left-wing ('dovish') and social-democratic in their ideological outlook. Parallel tendencies were generally found in Spain - but with the exception of the religious cleavage, the effects were much weaker.

What do these findings portend for the study of Occupy-type social movements, and the social movement literature more generally? Our research moves away from the prevailing focus on the core activists of the recent socio-economic protests and their novel practices to the less-studied 
hinterland of passive and active supporters. This perspective highlights the challenges faced by any social movement aspiring to appeal to and mobilize the mass public, an aspiration that was expressed in the Spanish and Israeli protests by framing their critique in very broad terms ('economic injustice', 'political unaccountability'), widening the boundaries of the social movement community ('the middle class', 'persons', 'the people'), and portraying their concerns and demands as 'apolitical' and even 'commonsensical'. Our findings imply that these framing efforts paid off for the $14 \mathrm{~J}$ and $15 \mathrm{M}$ movements. Both movements, especially in Israel, attained considerable levels of support. However, the fact that politicized social and ideological cleavages ostensibly unrelated to the gist of the protests nonetheless structured both passive and active support for them draws attention to the role of everyday politics in structuring engagement in these movements. The effects of this structuring are evident in a glass ceiling mechanism that was especially important for participation in performative forms of support, and also received expression in the increased polarization of passive support as the cycle of contention progressed. Are unconventional social movements irremediably tied to institutionalized political cleavages despite their unequivocal attempts to distance themselves from 'divisive old-time politics'? Future comparisons with the similar movements that emerged in less-fractured societies - the Portuguese Geração à Rasca and the Greek 'Indignados' mobilizations - may shed light on this important question.

\section{Bibliography}

Anduiza Eva et al. 2013. 'Mobilization through Online Social Networks: The Political Protest of the Indignados in Spain', Information, Communication \& Society, 17 (6): 1-15.

Arian Asher. 2005. Politics in Israel: The Second Republic, $2^{\text {nd }}$ Edition. New York: CQ Press.

Benski Tova et al. 2013. 'From the Streets and Squares to Social Movement Studies: What Have We Learned?', Current Sociology, 61: 541-561.

Calvo Kerman. 2009. 'Calidad de la democracia, derechos civiles y reforma de la política', in Bosco A., Sánchez-Cuenca I. (eds.), La España De Zapatero: Años De Cambio, 2004-20o8. Madrid: Fundación Pablo Iglesias: 205-27.

Calvo Kerman et al. 2010. 'A Difficult Friendship: Religiosity, Ideology, and Vote in Spain', XXIV Convegno della Società Italiana di Scienza Politica, Venice,16-18 September.

Calvo Kerman, Montero José Ramón. 2002. 'Cuando ser conservador ya no es un problema: religiosidad, ideología y voto en las elecciones generales de 2000', Revista Española de Ciencia Política, 6:17-56.

Castells Manuel. 2012. Networks of Outrage and Hope: Social Movements in the Internet Age. Cambridge: Polity.

Centre for Sociological Research (CIS). 2009. 'December 2009 Barometer'. Retrieved 6 January 2013 from http://Www.Cis.Es/Cis/Opencm/Es/1_Encuestas/Estudios/Ver.Jsp?Estudio=9942. 
Fishman M. Robert. 2012. 'On the Significance of Public Protest in Spanish Democracy', in Jordana Jacint et al. (eds.), Democràcia, Política I Societat: Homenatge a Rosa Virós. Barcelona: Universitat Pompeu Fabra, 351-366.

Grinberg Lev Luis. 2013. 'The J14 Resistance Mo(Ve)Ment: The Israeli Mix of Tahrir and Puerta Del Sol', Current Sociology, 61 (4): 491-509.

Hermann Tamar et al. 2012. The Israeli Democracy Index, 2012. Jerusalem: The Israel Democracy Institute.

Klandermans Bert. 1997. The Social Psychology of Protest. Oxford (UK); Cambridge, MA: Blackwell Publishers.

Montero José Ramón et al. 2008. 'El Voto Religioso en España y Portugal', Revista Internacional de Sociología, LXVI: 19-54.

Perugorría Ignacia. 2012. 'Identity Battles, Social Movement Networks and Political Opportunity Structures in the Basque Public Space: Bilbao's Aste Nagusia (2009-2010)', in Tejerina Benjamín, Perugorría Ignacia (eds.), Global Movements, National Grievances. Mobilizing for 'Real Democracy' and Social Justice. Bilbao: Servicio Editorial de la Universidad del País Vasco, 467-501.

Perugorría Ignacia, Tejerina Benjamín. 2013. 'Politics of the Encounter: Cognition, Emotions, and Networks in the Spanish 15M', Current Sociology, 61 (4): 424-442.

Rosenhek Zeev, Shalev Michael. 2013. 'The Political Economy of Israel's “Social Justice" Protests: A Class and Generational Analysis', Contemporary Social Science:Journal of the Academy of Social Sciences, 9 (1): 31-48.

Shalev Michael. 2012. 'The Economic Background of the Social Protest of Summer 2011', in Ben-David Dan (ed.), State of the Nation Report: Society, Economy and Policy in Israel 2011-2012. Jerusalem: Taub Center for Social Policy Studies in Israel, 161-22o.

—. 2007. 'The Welfare State Consensus in Israel: Placing Class Politics in Context', in Mau Steffen, Veghte Benjamin (eds.), The Welfare State, Legitimacy and Social Justice. Aldershot: Ashgate, 193-213.

Shalev Michael, Levy Gal. 2003. 'The Winners and Losers of 2003: Ideology, Social Structure and Political Change', in Arian Asher, Shamir Michal (eds.), The Elections in Israel - 2003, Brunswick, NJ: Transaction Books, 212-32.

Tejerina Benjamín. 2010. 'The Logic of the Alterglobal Movement: Between Experiences of Exceptionality and Structures of Everyday Life', in Singharoy K. Debal (ed.), Dissenting Voices and Transformative Actions: Social Movements in a Globalizing World. New Delhi: Manohar, 41-67.

Tejerina Benjamín et al. 2013a. 'From Indignation to Occupation: A New Wave of Global Mobilization', Current Sociology, 61 (4): 377-392.

- 2013 b. Crisis y empleo juvenil en Europa. Una perspectiva del Sur; ¿una solución europea? Madrid: Consejo de la Juventud de España.

Ubasart G. Gonzalez. Forthcoming. 'Action in Context. 15M, Democracy, Demands and Territorial Specificities in Catalonia and the Basque Country', in Tejerina Benjamín, Perugorría Ignacia (eds.), 15M: Crisis Movements in Contemporary Spain. London: Ashgate. 
Part 2

The Practical and Spatial Dimensions of Activism 



\title{
5 "We Must Register a Victory to Continue Fighting"
}

\author{
Locating the Action of the Indignados in Madrid
}

Hélö̈se Nez

The movement of the Indignados in Spain began on 15 May 2011 - hence the name ' $15 \mathrm{M}$ movement' - following a demonstration organized by several collective bodies united under the Real Democracy Now platform. ${ }^{1}$ Tens of thousands of people took to the streets in several Spanish cities to denounce the social consequences of the economic crisis and the way in which their government was managing that crisis. What also mobilized the Indignados into action was their indignation over the failures of the representative political system and of the capitalist economic model. At the end of the demonstration, a group of young people stayed and camped on the Puerta del Sol, a symbolic square in the center of Madrid (itself the center of Spain). The group stayed for almost one month as a self-managed encampment that organized public assemblies. The movement then branched out into other neighborhoods of Madrid, eventually expanding to a national scale with encampments multiplying on the squares of numerous city centers.

This chapter is about the articulation of the different scales of action local, national, and international - within that mobilization. Even if the Indignados' claims mainly concerned a national framework, their critique was also directed at the global level: their protests often included denouncements of the excesses of global finance and neoliberal capitalism. They therefore rapidly sought to internationalize their action. At the same time, they decentralized their assemblies to the scale of the neighborhoods and gradually narrowed down their activities to concrete and local issues. To sustain their mobilization for the long term, the Indignados then developed decentralized forms of organization as well as territory-oriented concrete actions, following the example of the struggles against home foreclosures. As they rejected the electoral avenue to bring about political change, they had to find places of action that would allow them to beef up their mobilization

1 I wish to thank Marcos Ancelovici, Sophie Béroud, Pascale Dufour, and Albert Ogien for their comments. This chapter was translated from the French by Patrice Cochet-Balmet with funding from CITERES. 
and to record first victories. The context of social emergency surrounding the nascent mobilization also meant that they had to achieve solid results so as to be credible and to continue the fight, since "the organisations of social movement fighting against precariousness must prove their usefulness to be able to rally the sympathy, let alone the commitment, of those whose cause they claim to defend" (Mathieu 2007: 248).

This process of locating collective action has often been neglected by sociologists studying social movements, who generally focus on the relationship between the activists and the state - in a context where its role was growing - or on the transnational character of contestation (Voss and Williams 2012). It has, however, been the subject of recent analyses regarding in particular the global justice movement and the collective action in Latin America. Merklen and Pleyers write that "numerous local movements and actors have placed their hopes in transforming at the local level, seeing there an appropriate framework to improving their life conditions and the quality of the social connections" (2011: 25). Voss and Williams also look at "how social movements have shifted their repertoire of practices from large mass events aimed at marking demands on the national state to local-level capacity building that seeks to democratize the local state and create parallel democratic spaces" (2012: 354). This renewed interest in local issues can be attributed to the recent shifts that have taken place in social movements, especially from the national scale towards more targeted action and from the working world towards other, more diversified social issues. Merklen (2008) has detailed how, since the 1980 s and increasingly since the economic crisis of 2001, the neighborhood in Argentina has become a privileged location for building solidarity and cooperation in the face of weakening union affiliation and reoriented social policies. And Pleyers (2011) demonstrated how the failure of the indigenous movements in Mexico to negotiate with the government and have an alternative candidate elected prompted them, from 2001, to focus on the construction of alternative societies on a local scale. Can we see a similar evolution in the case of the Spanish Indignados and if so, what are the factors behind it? How do social movements actually shift from collective action on national and global claims towards more concrete and local modes of action? What debates are fuelled by that location of mobilization among the participants, and what consequences does this have on their representations of policy and collective action?

My analysis is based on field research conducted in Madrid since the end of May 2011. I observed firsthand the dynamics of the encampment, the general assemblies, and the committees and working groups meetings set up by the Indignados in not only Puerta del Sol but also several 
neighborhoods (more than seventy meetings in total). I also took part in some ten demonstrations and other activities organized by the Indignados: cultural events, conferences, and direct and/or symbolic actions against home foreclosures and in banks. I mingled with the crowd during major gatherings, jotting down notes and shooting the scenes I was observing. Some of the smaller groups sometimes enticed me to take the floor and commit myself as an activist. In an ethnographic approach, I integrated mutual knowledge networks in a Madrid neighborhood (Carabanchel) and a town of the south suburb of Madrid (Parla). For this chapter, I have relied on my observations during the movement's activities combined with informal and semi-directive interviews with some fifty Indignados. I also used photography as a memorization medium on a par with the field diary (Conord 2007). My analysis is finally based on my documentation work on the written, photographic, and audiovisual productions of the movement.

A chronology of the Indignados movement will enable us to understand how the movement has transformed with the passing of time. The idea is to decipher the modes of action and the commitment logics underlying both main watchwords: 'Toma la plaza' ('Take the square') and 'Toma los barrios' ('Take the neighborhoods'). The movement's first step involved large-scale national demonstrations, encampments on public squares, and assemblies with thousands of participants in the town centers. From the beginning, the Indignados have demonstrated a strong will to internationalize their mobilization. The second step was the decentralization of the movement to the level of the neighborhoods and the shift towards local and concrete issues, which enabled the Indignados to record their first victories but which also revealed the limits of localized action. One year later, due to the declining participation of the neighborhood assemblies, the Indignados began developing new strategies at the national level which emphasized the complementarity between the different levels of intervention.

\section{Encampments in the City Center and Large-Scale Demonstrations}

The first phase of the Indignados movement, which received the most media attention, only lasted from May to June 2011. Following the example of Puerta del Sol, encampments multiplied on the central squares of several Spanish cities. The Madrid encampment itself did not last more than one month. Established on the evening of 15 May, it was disbanded on the initiative of the Indignados on 12 June after fierce debates in the 
Puerta del Sol general assembly. In spite of their relatively short duration, these encampments had a considerable influence on the 15 May movement, more specifically on its forms of organization and internal democracy. In this first phase of the movement, participation was the most large-scale and the most heterogeneous, bringing together people who were already militants (mainly organized young people, especially in the autonomous movements, who decided to set up camp on the first evening) and others belonging to older activist generations or those still not accustomed to collective action, who joined the encampment in massive numbers in the following days. To explain the different facets of the first phase of the mobilization, I first analyze the claims of the demonstrators and discuss the democratic practices set up during the encampment before turning to the internationalization strategy of the movement.

\section{Demonstrating Against a Faulty Political and Economic System}

The 15 May demonstration, the starting point of the Spanish Indignados, was not initiated by conventional organizations such as trade unions or political parties but rather by collective bodies formed on the Internet (as well as certain older groups such as Attac-Spain) and who transmitted the call to action through social networks. In their first press release on 1 March 2011, they described themselves as "representatives and militants of several groups, blogs and platforms [...] united under the common designation 'Platform of coordination of groups for citizen mobilisation'”. The call to action emphasized the global dimension of contestation ("To be able to show, as in many other countries around us, social discontent on the increase") and linked the claims to the national context by denouncing the perverse economic and political system at the origin of the crisis in Spain:

After several years of crisis and absolute inanity of the Spanish political class, [...] a multitude of movements organised by citizens finally took shape with a basic point in common: to denounce the severe deficiencies and the injustices of the current economic and governmental system, and to demand a real democracy.

2 This quote and the following ones originate from http://lacomunidad.elpais.com/ ezpala/2011/3/2/-indignate-inminente-convocatoria-la-plataforma-de. Retrieved 22 January 2013 . 
The motto of the 15 May demonstration - "Real democracy NOW. We are not commodities in the hands of the politicians and bankers" - underlined the responsibility of the "political and economic powers" to address "the hardship befalling the citizens". The initial claims of the movement thus addressed two levels - mainly national but also international - and highlighted the responsibilities of the political system as well as the economic model in the social crisis affecting Spain. At the political level and in the national context, the 'they' in the motto "They do not represent us" referred to several organizations. The main targets were the government and the party in power (the Socialist Party or PSOE), which were deemed unable to provide satisfactory responses to the economic crisis, as well as the right-wing opposition (the Popular Party or PP) which promoted the same austerity policies. Both these entities were generally grouped under the expression "mainstream parties" and contemptuously dismissed in the quip 'PPSOE'. The Indignados also denounced the two-party system as well as the electoral laws that promote bipartism in Spain. The position of the Indignados as regards the smaller parties such as Izquierda Unida ('the United Left') was more ambivalent: some considered them a genuine alternative, whereas others failed to distinguish between these smaller parties' local management and the political agreements they made with the mainstream parties. The parties were not the only ones to be accused; individual political officials were also denounced on account of numerous cases of corruption linked to real estate speculation. The manifesto of 'Real Democracy NOW!', which called on Spanish citizens to demonstrate on 15 May, denounced the role of elected officials in the economic crisis:

In this case, most of the political class does not even listen to us. They should aim to carry our voice to the institutions, [...] not to get rich and to succeed with us, solely by obeying the dictates of the major economic powers and clinging to power. ${ }^{3}$

The mainstream trade unions - the Workers' Commissions (CCOO) and the General Union of Workers (UGT) - were also targeted in the motto "They do not represent us". Their credibility had been heavily damaged when they negotiated a controversial agreement on pension reform with the government earlier that year. In the public assemblies, however, the Indignados' position on the unions was far more ambiguous than their stance towards the political parties, since several participants were union activists (Calle 
and Candón 2013). A differentiation was thus quickly established between the "basic" or "combative" unions and the mainstream unions.

The denunciation of any form of political representation also extended to the neighborhood associations, albeit to a lesser degree, once the movement began decentralizing in Madrid. I thus observed fierce debates in neighborhood assemblies regarding their role in the $15 \mathrm{M}$ movement and their alleged distance from the people (Nez 2012). These criticisms should be understood in historical context: having acted as strongholds of the political contestation under the Franco dictatorship, they became the main interlocutors of the local public authorities with the return of democracy, and their action has gradually become institutionalized (Navarro 1999; Alguacil 2013).

The claims of the Indignados were not only part of a political context specific to post-dictatorship Spain, they could also be placed within an international framework. The outbreak of the real estate crisis in September $2008^{4}$ led to social consequences that were particularly painful in Spain. By the first trimester of 2011, the unemployment rate had skyrocketed to 21 per cent of the labor force, which amounted to nearly five million people. More than 45 per cent of those between the ages of 16 and 25 were unemployed double the average in the European Union. ${ }^{5}$ Home foreclosures multiplied: 32,000 households were affected by foreclosure procedures between January and June 2011, i.e. an average of 175 per day. ${ }^{6}$ Given the brutality of this social crisis, the assemblies of the Indignados often denounced the responsible economic actors - banks, international rating agencies, financial markets: "I would like to talk about bankers, [...] they mortgaged our lives, they control everything, they successfully made us dependent on them. It was the most important problem in this country, together with the privileges of the politicians, we should get rid of all that!". ' The banks were thus targeted because during the years of real estate speculation they had sold overrated real estate and offered risky credit to numerous households who then became insolvent with the crisis. They also jeopardized the national economy to the point where the government had to step in and use taxpayers' money to 'save' them. The bank rescue packages and the ensuing budget cuts were imposed or advocated by international institutions such as the European Union, the IMF, and the World Bank, which were also included in the motto

\footnotetext{
For an analysis of the economic crisis, see Ross's chapter in this volume.

Data of the National Institute of Statistics.

Data of the General Council of the Judicial Power.

Observation at the general assembly of Carabanchel, on 28 May 2011.
} 
"They do not represent us". The Indignados denounced these measures, decrying the fact that they were adversely affected by them even though they had not voted for them.

In addition to the economic actors and the international institutions, the Indignados also focused their criticism on the capitalist model itself, as explained in their call to demonstrate:

The obsolete and anti-natural economic model in force blocks the social machine in a self-destructive spiral by enriching a few and plunging all the others into poverty and scarcity. [...] An ethical revolution was necessary. We have placed money above human beings, and we must put it back in our service. We are people, not market products.

The criticism against capitalism thus played a significant role in the Indignados' discourse and in the emerging mobilization, a fact that has generally been neglected in the literature on social movements (Hetland and Goodwin 2013). However, surveys conducted in several Spanish cities (Calvo et al. 2011; Arellano et al. 2012; Likki 2012) demonstrated that the Indignados did not necessarily belong to the social categories most affected by the economic crisis: although students and the unemployed took part in the demonstrations, most participants had a job and a high level of education. ${ }^{8}$ Nor did the majority of the demonstrators belong to the most socially and politically excluded: only a few Indignados were involved in social or political organizations, but they voted more often than the average citizen.

\section{Camping and Getting Organized to Claim Another Democracy}

The rejection of conventional forms of political representation was a defining feature of the Indignados. The manifesto of the general assembly of Puerta del Sol stated that they were "free and voluntary people [...]. We do not represent any party or association." ${ }^{\prime 9}$ One of the first messages of the Real Democracy NOW platform, published on the Kaosenlared.net site on 7 March 2011, already defined the movement as a group of individuals rather than a group of organizations: "We are calling upon all of you, as citizens, to take to the streets on 15 May [...]. We entice you to join us without the symbol of any organization". Handwritten signs created by individuals multiplied on the encampment, whereas banners furnished by organizations were

8 See the introduction of this volume.

9 Retrieved 15 January 2013 from http://madrid.tomalaplaza.net/manifiesto-2/. 
systematically withheld. This demonstrates that an individual aggregation rationale rather than a network rationale was at work here (Juris 2012). Some of these banners made references to the Spanish Civil War (see Photo 5.1: "We're doing it for you, grandfather"; "Welcome to the Independent Republic of our square"). These references to the recent history of Spain illustrate that the contestation was originally part of a national context, even if it also entailed a more global denunciation of capitalism and international finance.

\section{Photo 5.1 Memories of the Spanish Civil War}

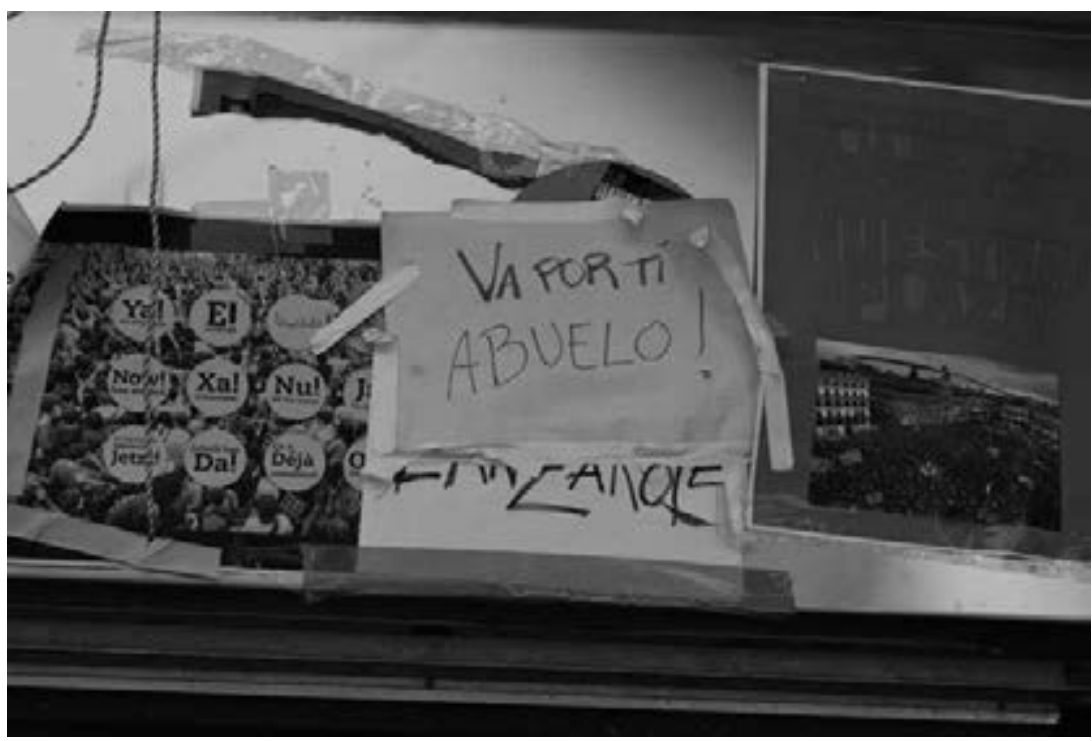

Skepticism of the representative political system went hand in hand with the Indignados' claim to be implementing 'another democracy', a 'real democracy' based on the principles of self-management, deliberation, and participation open to all. The prominence given to the practices of internal democracy makes this movement stand out from other movements (Adell 2011; Nez and Ganuza Forthcoming). The idea was admittedly not new, since the practice of horizontality and consensus had already been incorporated first by the anarchist and libertarian movements (Graeber 2009), then by the 'new social movements' of the 1960s-70s (Polletta 2002), before becoming one of the standard bearers of the alterglobalist movement in the late 1990s (Della Porta 2009). In Spain, the deliberative techniques used by the Indignados originated especially from the Okupa ('squatters') movement, who experienced them in the 'self-managed occupied social 
centers' during the 1980s (Martínez and García 2012) and in the movement against the military intervention in Irak in 2003 and after (Flesher Fominaya 2010). However, in the case of the Indignados, internal democracy was at the center of most debates and had acquired a new dimension: consensus was sought not only within relatively homogeneous activist microspheres or between organizations and movements that had to make compromises (as in social forums) but also between heterogeneous individuals seeking to produce common positions (Aguiton and Haeringer 2012; Nez and Ganuza 2015). As emphasized by Romanos: "The $15 \mathrm{M}$ promoted the transfer of the deliberative practices from more or less limited enclosures (for instance, the encampments, social forums or self-managed centers) towards the squares, and it seemed to constitute a significant difference" (2011: 9). At Puerta del Sol, the decisions were made in general assemblies, since the work was prepared upstream in more restricted groups: the committees dealt with the practical problems of that self-managed space (infrastructure, food, health, etc.), and the working groups (on economics, politics, education, etc.) prepared projects and propositions to change society. Common rules were gradually formalized, such as horizontality among groups, rotation of the speakers, functions in the assembly (moderating, taking turns to talk, and writing minutes), and consensus-based decision process. ${ }^{10}$

The themes addressed in the assemblies of the encampment were quite various, as reflected in the multitude of thematic working groups. From the onset, the participants tried to reach a 'consensus on the fundamentals' in order to respond in particular to the media denouncing their lack of program and propositions. Numerous debates addressed the vital necessity of such a consensus, which nonetheless eluded the movement for several reasons. The particularity of the movement lay in the absence of a program and a leader, and the internal divergences were significant due to the heterogeneity of the participants. One of the most acute conflicts addressed the movement's relation to the political sphere. The working group on politics was from the onset split in two subgroups - one focusing on short-term policies and the other on long-term policies - which met on the same day at the same time on two different squares. The group on short-term policies sought to weigh in on public policies being considered at the national level. The members agreed on four propositions to try and improve the current system:

10 In addition, I have developed an ethnography of the deliberation and consensus at Puerta del Sol (Nez 2012). For a comparison with the practices of the North-American Occupiers, see Ancelovici's chapter in this volume. 
1) Reform of the electoral law for a more representative democracy, really proportional and developing effective mechanisms of citizen participation; 2) fighting against corruption through standards aiming to provide total political transparency; 3 ) effective separation of the three powers (executive, legislative, and judicial); 4) creation of citizen control mechanisms to demand real political responsibility. ${ }^{11}$

During this time, the group dealing with long-term policies focused on the mode of political organization to be achieved based on self-management and public assemblies as practised in the Puerta del Sol encampment. This group believed that there was no point in trying to influence the current political system and that to change it was the only way forward. Still, such a change could not involve the electoral avenue but instead would entail the promotion of local experimentations, such as the occupancy of buildings or the creation of cooperatives with the aim of developing an alternative economic model to the capitalist system. In an autonomous and libertarian vein, the objective was to construct a counter-culture opposing the dominant culture and to form 'pockets of resistance'. The tension between the two groups was particularly acute on the issue of electoral participation: the first group believed it was possible to establish a series of propositions and to hold political candidates accountable on that basis; for the latter group, the idea was not to toe the line of a particular electoral program but to follow one's own fighting program. A participant in the first social Indignados forum on 25 July 2011 proposed a middle way: "The $15 \mathrm{M}$ movement is so variegated that it could never become a political movement with a political program, but political allies can be contemplated who, using the institutions, might defend what the $15 \mathrm{M}$ stands for." However, in the runup to the legislative elections of 20 November 2011, the Indignados not only refused to adopt a political program and to designate leaders, they also withheld from backing candidates or political organizations.

This rejection of the electoral path was confirmed during the general assembly at Puerta del Sol held on election day. The moderation and sound system team arrived at the square at $5.40 \mathrm{pm}$, ten minutes after the meeting was summoned, whereas the polling stations had not yet closed. After a quick negotiation with the police, the meeting was allowed to take place provided that no political party or candidate was mentioned by the

11 Retrieved January 15, 2013 from http://madrid.tomalaplaza.net/2011/05/26/acampada-solconsensua-cuatro-lineas-de-debate/comment-page-16/. 
participants. The moderator opened the session by clarifying the position of the assembly: "As every Sunday, we celebrate democracy here. Today is election day and of course, no speaker will advocate voting for any party. We are taking care of our own business, as every Sunday, to change the world, for a fairer society" (field notes). The working group on the 20 November elections was the first to take the floor: "We shall continue after 20 November to give information, so that everybody understands the elections, the types of votes, and the electoral law. Not to tell whom to vote for, but to fill this information gap" (field notes). This working group, which had been meeting regularly since the summer, was having difficulty defining the movement's position on the elections, as one of its active members was telling me at an assembly of the group which, two days before the ballot took place, was attended by more journalists than participants. No consensus could be reached; the only thing that could be agreed on was an informative role aimed at discouraging electors from returning a blank ballot (since that would strengthen the mainstream parties to the detriment of the smaller parties) and at advising them to either abstain, cast an invalid vote, or vote for the minority party of their choice. Individual initiatives sent a clearer message to the population, with several Indignados displaying, a few days before the ballot in Puerta del Sol, a photo of their face showing the sign of silence, with the following caption: "Vote and be quiet. They lie, they squeeze the budget, they steal. Unfair electoral law. Invalid or minority vote" (Photo 5.2).

\section{Seeking to Internationalize the Movement}

During this first phase, the movement's global dimension was blatant and was expressed in two ways. First, the Indignados gathered at Puerta del Sol claimed to have been inspired by external modes of mobilization, mainly the Arab revolutions (to start with the occupation of Tahrir Square in Cairo) but also the more recent protests in Greece and Iceland. The signs installed on the square bore witness to these international sources of inspiration: the word 'revolution' inscribed in Arabic (Photo 5.3), a comic strip recalling the different steps of the mobilization in Iceland, and copies of a newspaper article entitled "Iceland is judging the first political official in charge for poor management of the crisis" (Photo 5.4). In the general assemblies at Puerta del Sol, the participants often referred to the Tunisian and Egyptian revolutions, to the referendum by which the Icelanders refused to pay for the mistakes of the bankers, or to the demonstrations in France against pension reform in the autumn of 2010. 
Photo 5.2 "Vote and be quiet"

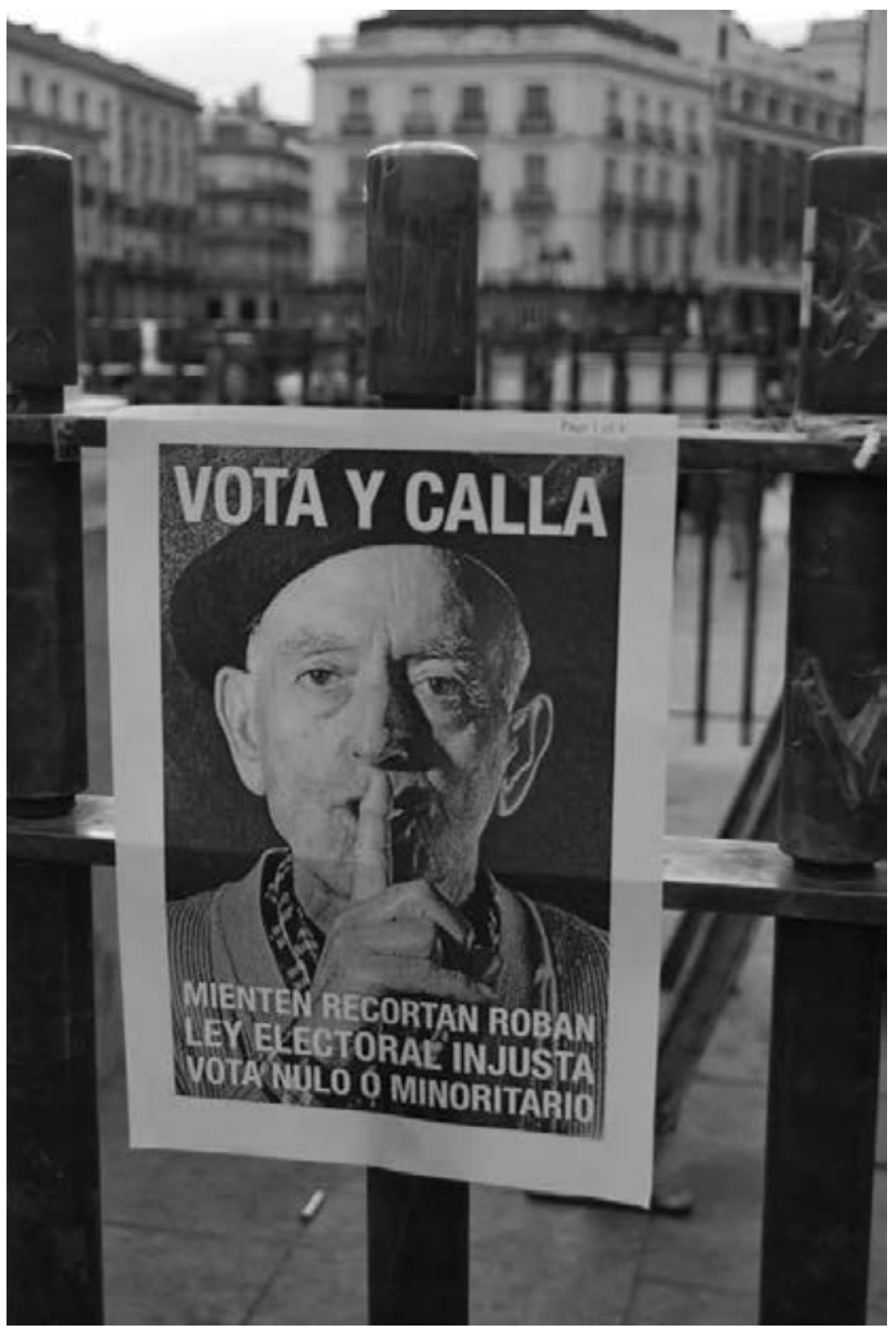


Photos 5.3 and 5.4 International References to the Encampment
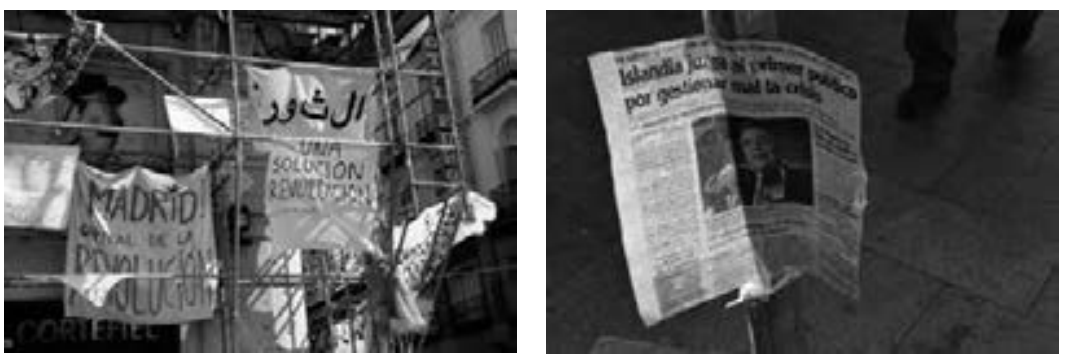

The Indignados immediately granted paramount importance to the international diffusion of their movement. An 'international extension' commission was set up during the first days of the encampment. Its role was to "connect Madrid with the other cities of the world"12 by diffusing the 'model' of the Puerta del Sol encampment throughout the world. This was achieved through the Internet, social networks, and direct contacts - via the Spanish diaspora and activists travelling - to New York, for instance (Romanos 2013a). This international diffusion of the model also involved translating the documents prepared by the general assembly at Puerta del Sol into twenty languages. In the general assemblies, the 'international extension' commission systematically gave news about encampments in other countries, even if this meant interrupting the discussions in progress. At a general assembly on 29 May 2011, while debating whether to maintain the encampment at Puerta del Sol or not, the participants followed the evolution of the movement in Paris hour by hour. At the beginning of the assembly (8.30 pm), a spokesman joyfully announced that "the Bastille has been taken!" At 9.30 pm, a direct communication established by mobile phone indicated that the demonstrators were peacefully resisting the police forces' attempts to disband them. Thousands of participants began singing: "Paris resist, Madrid is with you!" At 9.40 pm, a minute of silence was observed to support the Parisians subjected to police repression. In the evening, the 'international extension' commission also reported a largescale demonstration in Athens as well as several support demonstrations by the Spanish and Latin-American communities in Brussels and in several German cities.

12 Intervention of a spokeswoman of that commission at the general assembly of Puerta del Sol, on 28 May 2011. 
This determination to serve as a "symbol for numerous peoples in Spain and in Europe ${ }^{113}$ explains why the encampment lasted close to one month at Puerta del Sol, even though some had suggested bringing it to an end after two weeks. The aim of prolonging the encampment was to support the other encampments that were being subject to repression, as expressed by one participant: "Good reasons have been put forward to lift the camp, all of them are reasonable. I have one only: 200,000 people in Athens, 20,000 in the Bastille [overestimated figures] who, at this very moment, are being arrested, and we should leave?!"14 After the encampment was discontinued, the general assembly of Puerta del Sol continued to disseminate information about the international dimension of the mobilization by regularly giving the floor to foreign activists, for example from Morocco, Tunisia, Mexico ('Yo soy 132'), or the United States (Occupy).

\section{Decentralizing and Refocusing Collective Action on Concrete Issues}

Another strategy was conducted in parallel to the internationalization of the movement: the tactic of decentralizing down to the level of the neighborhoods, carried out by the 'neighborhoods' commission. Although disagreements still remained among a portion of the campers, the most precarious who ordinarily slept on the street or in squares, the vast majority of the Indignados interpreted their abandonment of the Puerta del Sol encampment on 12 June 2011 as a change of strategy. "Nos vemos en los barrios" ("Let us meet in the neighborhoods") was written on the large sign displayed that day on the entrance to the underground at the Puerta del Sol - a clear reference to the expression "Nos vemos en la plaza" "Let us meet on the square") used by the Indignados during the weeks of the Puerta del Sol encampment. The participants thus began singing the motto "Que no nos vamos, nos extendemos!" ("We are not going, we are growing!"). The idea was to anchor the mobilization at the local level so that it did not lose its momentum and to ensure the continuation of the movement by cutting it off from the necessarily temporary future of the encampment, as recalled by the moderator at the general assembly on 29 May: "The object of the assembly is to know what we are going to do with the encampment. One thing is clear: the movement continues, regardless whether the encampment continues or not!" 


\section{The Movement's Decentralization}

The first neighborhood assemblies were organized on 28 May 2011, after preparation by the 'neighborhoods' commission. This commission was adamant about making the extent of the movement's decentralization visible at the Puerta del Sol encampment by indicating the neighborhoods and cities that had held their first assembly on a signpost (Photo 5.5). The Sol general assembly had earlier provided a methodological proposition to the neighborhoods in order to define common rules: "The object will be to promote in all the assemblies of the movement a horizontal, transparent operation, enabling everybody to take part on an equal basis." The system of assemblies set up at Puerta del Sol was thus transferred to the neighborhoods and suburbs of Madrid. During the first neighborhood assemblies, the turnout was massive. According to the 'Toma los barrios' site, they were organized in more than 140 neighborhoods and suburb towns, drawing more than 28,00o participants in total. ${ }^{15}$ The first popular assembly in Madrid (APM), held on 29 May 2011, reflected these dynamics. The spokesman of each neighborhood was invited to sum up in two minutes the assembly of the previous night, but this meant that five hours were necessary for all the neighborhoods to take the floor. These physical encounters - as well as the madrid.tomalaplaza.net website, a common working platform (https://n-1.cc/), and the Facebook or Twitter social networks - ensured that the actions taken by the different neighborhoods and peripheral towns were all coordinated and harmonized.

The first assemblies focused on debating about their internal organization (setting the location, dates, and times of the meetings; defining working groups) and turning the global claims of the Indignados into action on the local scale. For instance, at the first assembly of the popular neighborhood of Carabanchel, in the south of the city, several lines of work emerged: housing, employment, immigration, education, and health. Concrete propositions were formulated with respect to each neighborhood's specific situation: setting up picket lines at each redundancy scheme by a local company, opposing any home foreclosures, reclaiming available plots to create housing and social facilities, seeing to it that hospitals benefit the inhabitants of the neighborhood, fighting to prevent the closure of a public school, etc. The process of decentralization of the assemblies was also debated. The object was to articulate global ideas with concrete propositions on the ground so as to implement the maxim 'Think global, act local' which had already proved 
itself in the global justice movement. The Indignados thus found legitimacy for pursuing their action. Participants, however, emphasized the limits of that territorialized approach, for example in Carabanchel: "The problems we have in the neighborhoods are common to all the neighborhoods. The problem is the world in which we live. I believe that Spain and not only this neighborhood should find solutions to its problems in this assembly". Many participants in these first assemblies felt there was a risk that the movement would be confined to the local, thereby raising the issue of the relevancy of a territorial organization to cope with problems whose origins are more global than local, even if the repercussions were being felt on all levels.

This decentralization and implementation of action at the level of the neighborhoods did not mean that the Indignados had given up on their national and global strategy. First of all, the local actions, even if they were specific to a territory, often corresponded to more global issues. Focusing on the local scale did not mean restricting the movement's scope to the neighborhoods. The APM, for instance, strove to have the neighborhood assemblies switch their actions to a larger scale. As noted by Merklen and Pleyers: "The local anchorage of actors and of mobilisations is absolutely incompatible neither with the national political link nor with a projection of citizenship beyond the frontiers of the state-nation. Besides, a local mobilisation does not always target a local adversary" (2011: 31). Moreover, it does not exclude taking action at other levels. The Indignados still wanted to claim international recognition, as confirmed when they convened a global demonstration on 15 October 2011. The website dedicated to the event, translated into 18 languages, specifies that the appeal was echoed in 1,040 cities in 90 countries. ${ }^{16}$ This globalization of the movement was proudly displayed on the square in the center of Madrid (Photo 5.6).

Another point is that even after the encampment was brought to an end, the general assemblies were still held at Puerta del Sol, even if they no longer took place daily but were held weekly. However, conflicts of legitimacy emerged as soon as July 2011 between the neighborhoods and the national organization of the movement, with participants' loyalties being pulled towards both sides. This tension was made apparent in the first neighborhood assemblies, for example by this participant: "I cannot be on the street everyday! We must prevent the dispersion from reducing the dynamics of the movement. We still have many things to do at the 
local level; we should not limit ourselves to major demonstrations. ${ }^{17}$ It was reflected in the growing conflict between the general assembly of Puerta del Sol (originating from the encampment) and the APM (which co-ordinates the activities of the neighborhood assemblies). The former, which enjoyed significant media attention, continued to pass on major action watchwords to the neighborhoods, whereas the latter believed that the principle of horizontality and autonomy meant that the general assembly of Puerta del Sol should not be conferred more legitimacy than any other neighborhood assembly (Nez 2012). This conflict was also apparent in spatial terms: whereas both assemblies initially met at Puerta del Sol at flexible hours, the APM moved to Plaza del Carmen "because it was stealing the show from the general assembly of the Puerta del Sol" which held its assembly at the same time, according to a participant in an informal interview.

\section{Photos 5.5 and 5.6 Showing the decentralization and the internationalization of the movement}
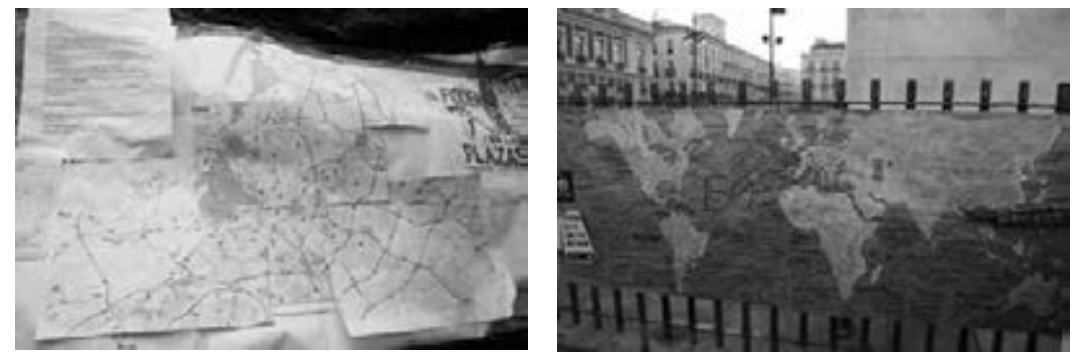

\section{Concrete and Local Mobilization Issues}

The risk of demobilization as a result of these conflicts was partially curbed by the first victories recorded by the movement - victories that were made possible by decentralization. On 4 June 2011, at the end of the general assembly of Carabanchel, the 200 participants who stayed to talk on the square were tipped off that the police were conducting ethnic profiling at the Oporto metro station. By showing up in large numbers at the control location, the Indignados in effect caused the police officers to leave. The news of this 'roundup' of immigrants rapidly spread in the working class areas of Madrid, which proposed to repeat the experiment. Four days later, 
a press release was issued by the Alucha neighborhood entitled 'Message to the $15 \mathrm{M}$ : A small major victory in Carabanchel':

That time, we were not alone, isolated, and defenceless. There were many of us, aware of being part of something bigger, of a still-growing movement, capable of large mobilizations and small gestures, such as that of Saturday, with a taste for victory. ${ }^{18}$

The Indignados thus put an end to several ethnic profiling practices being carried out in Madrid's metro stations. The 'effect of demonstration' was also quite powerful when they prevented a home foreclosure on 15 June 2011: an appeal launched by the assembly of Tetuán, a working class neighborhood in the north of the city, was indeed echoed by Indignados from all over Madrid. From then on, appeals multiplied to prevent home foreclosures in every corner of the capital city. Connections were rapidly established between the different neighborhood assemblies and existing social organizations (such as the human rights defence brigades or the mortgage victims' platform $[\mathrm{PAH}])$ so as to take direct action against the main social consequences of the economic crisis: home foreclosures, ethnic profiling practices, closing of social services, layoffs, etc. Even if they did not change the political and economic system, these concrete actions guaranteed the continuation of the movement, as expressed by a sixty-year-old man at the general assembly of Carabanchel on 11 June 2011 in referring to the occupation of a home for the disabled that had recently been closed in his neighborhood: "We must register a victory, however small, to continue fighting."

In all the neighborhoods, we also found concrete practices of social solidarity, like the organization of soup kitchens helping destitute and homeless people or the creation of barter exchange networks, mutual assistance networks, and time banks - whose aims were to exchange goods or free services in the surrounding environment. As analyzed by Ibarra:

This tendency of the movement to convert to a self-managed community - which rather characterises certain Latin-American social movements, whereas the 'westerners' only focused on the claim dimension confronting the public authorities - started to play a vital role in the $15 \mathrm{M}$ movement. (2013:13-14)

18 Retrieved o8 June 2011 from http://aluche.tomalosbarrios.net/2011/o6/o8/mensaje-almovimiento-15m-una-pequena-gran-victoria-en-carabanchel/. 
The idea was not only to offer solutions to people particularly affected by the economic crisis but also to show that other exchanges were possible outside the market economy. This was the case with the small number of thirty-year-olds involved in the 'action' Parla commission who in February 2012 submitted their proposal of extending the barter trade network that they had initiated locally. They initially offered the possibility of participating in the barter trade network to those who were penniless or unemployed - in other words, to those for whom bartering was a necessity. Soon after, they turned this experiment into a "population awareness" project to demonstrate that "another type of economy" was possible. One of the members highlighted the problems raised by the creation of social money: "We must find a way of oxidizing the social money to avoid repeating past mistakes of the capitalist economic system. How can we prevent people from accumulating money, to the extent that again some would have a lot and others a little?" The solution selected by the group was to rule out the use of social money and to rely instead on a barter system that would not be based on the material value of each good and that would establish trusting relationships among participants. As in the Argentine case - which had, incidentally, caught the interest of the commission that was gathering information on different barter trade systems in the world -, analyzed by Merklen (2008) further to the crisis of 2001, the neighborhood became a privileged location for the organization of acts of solidarity and cooperative efforts. To borrow the terms of Auyero (2005), the decentralization of the $15 \mathrm{M}$ movement was simultaneously the product of 'the situated space', whereas the collective action was part of the fabric of social connections and of daily pursuits, and of the 'attribute space'. The neighborhood in Spain had become a symbolic location of mobilization ever since the consolidation of the neighborhood associations at the end of the Franco dictatorship. Along with other neighborhood assemblies in Madrid, the assembly of Parla was at the origin of the creation of an 'urban vegetable garden' aimed at promoting another model of production and consumption. The Indignados thus focused on local and concrete actions that produced visible results, without losing the meaning and the global scope of their action.

The movement also turned to more radical action such as occupying vacant buildings. These buildings were used to rehouse families expelled from their lodgings as well as to provide a place to organize the movement's activities during the winter. For example, the disused premises of the 'Madrid Hotel', a stone's throw from Puerta del Sol, were occupied after the global demonstration of ${ }_{15}$ October 2011. Many similar initiatives were undertaken in the neighborhoods of Madrid (on a par with the Eko in Carabanchel) as 
in other towns in Spain, giving a renewed energy to the Okupa movement (Martínez and García 2012). In view of these developments, some Indignados noted in informal discussions that "the group on long-term politics won with respect to the group on short-term politics", referring to one of the main conflicts within the movement. The Indignados' rejection of the electoral path indeed led them to seek solutions to concrete problems in order to show the efficiency of their action at the local scale, due to their inability to influence policies at the national and international level. Looking at the indigenous movements in Mexico (Pleyers 2011), we can identify two factors at work in the location strategy of their collective action: the failure of the government to take the movements' claims into account and the redeployment of a political culture that sought to bring about social change at the local level. A similar attitude can indeed be found in the Indignados group 'on long-term politics', which believed that strengthening social connections anchored in daily life would not only improve social conditions but also offer alternatives to the dominant way of doing things (Pleyers 2010).

\section{On National and Transversal Actions}

However, these dynamics at the neighborhood level gradually petered out as the months went by, and participation in local assemblies plummeted. ${ }^{19}$ In Carabanchel, more than 500 people had occupied the Oporto square on 28 May 2011, but two weeks later this number was halved. By July, the number of participants had dropped to fewer than one hundred and then to just a few. Home foreclosures continued to mobilize the population to take action, and certain workgroups that were focused on very concrete issues such as housing attracted more participants than general assemblies in the neighborhoods. But demonstrators asked to join the movement rarely embarked on a long-term commitment. This can be explained by their precarious everyday lives, which made it difficult for them to commit to regular participation (Mathieu 2007). In addition, the way in which the assemblies operated - on the basis of consensus, which involves debating and speaking in public - tended to exclude those individuals least accustomed to collective action (Nez 2012). Paradoxically, and counter to the movement's intentions, the assemblies of the Indignados gradually turned

19 The local dimension is not necessarily the main source of the demobilization in the neighborhood assemblies, which can also be explained by militant fatigue and the form of commitment in this type of activism, more pregnant than in an organization with relays and supports. 
into 'assemblies of activists', to borrow the term of Castells. ${ }^{20}$ This issue was discussed by the commission on 'international extension' of the Puerta del Sol general assembly, which decided in mid-December 2011 to call a 'strike on activism'. By repeating the motto of Occupy Wall Street ("We are the 99\%"), this commission blew the whistle on the activist drift of the movement:

Perhaps that in addition [...] to calling structure on what is bureaucracy, associating the sovereignty of the assembly to what is dispersion and division; instead of all that, we might wonder why we are more invisible each time, why we are each time more disconnected from the people. ${ }^{21}$

One year after the encampment at Puerta del Sol and the decentralization of the movement to the neighborhoods, initiatives on the national scale were springing up regularly. Since the announcement of the bank rescue packages in the spring of 2012, many demonstrations against the banks and bankers were organized. On 14 June 2012, the Indignados filed a lawsuit against Bankia's board of directors in the name of thirteen small stockholders who had lost their savings, claiming falsified accounts and other fraud charges. The people incriminated included the former president of Bankia, Rodrigo Rato, who had also held the positions of economics minister and IMF managing director in the past. The Indignados thus sought to denounce corruption, the lack of transparency, and the collusion between economic and political elites during the years of real estate speculation. They drew on the example of Iceland, where the former prime minister was put on trial for his responsibility in the financial crisis. The movement's aim was to go beyond claims directed at banks and international financial institutions and directly target national officials responsible for the crisis. It was also the strategy followed in 2013 by the Mortgage Victims' Platform (Plataforma de Afectados por la Hipoteca, PAH) and the assemblies 'on housing'. The 'escraches ${ }^{22}$ aimed to put pressure on members of parliament to support their'popular legislative initiative' for alternative policies on housing (Romanos 2013b).

The actions and demonstrations were hence not limited to the scale of the neighborhoods but also continued on a national scale. The 'Rodea el Congreso' ('Surround the Congress') demonstration on 25 September

20 ‘¿Adónde van los “indignados”?', La Vanguardia, 21 January 2012.

21 Retrieved December 19, 2011 from http://madrid.tomalaplaza.net/2011/12/19/ extension-internacional-de-sol-se-declara-en-huelga-\%C2\%BFsomos-el-99/.

22 This form of demonstration, which emerged in Argentina, aimed to publicly condemn those responsible for an injustice by confronting them at their place of abode or their workplace. 
2012 to protest against the government's austerity policies attracted many people and unleashed unprecedented police repression. The Indignados also contributed to the emergence of movements beyond the local scale by organizing across sectors of public services affected by budget cuts. These were the 'waves' whose color referred to the T-shirts worn by the demonstrators - like the green wave for education or the white wave for public health - and whose mode of organization and internal democracy were inspired by the Indignados (Calle and Candón 2013). Thus, a transversal rationale governed the location strategy of collective action. This meant that more local action did not always displace national or global action - these different scales of action could also be complementary.

Since embarking on a decentralization of their movement (just two weeks after the emergence of the $15 \mathrm{M}$ movement), the Indignados in Madrid have articulated their actions at the local, national, and international levels. There was a certain tension in determining which level would be the most effective in asserting their claims. The movement's decentralization to the neighborhood level, which asserted itself as a strategic choice after the period of encampments, massive assemblies, and demonstrations of a national scope, can be explained by the search for a capacity of action. But what quickly became apparent was the limits of local action in the face of political, economic, and social policies, which arose on the national and international scales. Does the location strategy of collective action not boil down to a confession of helplessness from a social movement that refused to turn to the political arena to effect change? We agree with Pleyers' assessment of the location strategy of autonomous movements: "By shifting the fight from the political sphere towards that of the local space of the daily life, did these movements not leave the field to their adversaries as regards the influence they exerted on the government authorities and resorting to the institutions?" (2011: 51). The general elections of November 2011 thus resulted in the right-wing party winning an absolute majority in Congress. It was able to do so without significantly widening its electoral base, for the voters' rejection of the PSOE benefited the smaller parties, and abstention as well as spoiled or blank ballots increased. ${ }^{23}$ These results in part reflect

23 See, for example, the electoral analysis of the NGO Ecologistas en Acción, which puts into perspective the idea of a 'tsunami' of the right-wing party. Retrieved 4 December 2013 from http://www.ecologistasenaccion.org/article21804.html. 
the discourse used by the Indignados during the campaign, which called on voters to abstain, to submit invalid votes, or to vote for smaller parties. The 'Partido X' was launched in January 2013 with the aim of creating "a 15M in the electoral space". ${ }^{24}$ Podemos (which translates as "We can") is another political party that emerged as part of a continuation of the $15 \mathrm{M}$ movement in the political sphere, even if these initiatives came far short of encapsulating such a heterogeneous movement (Nez 2015). Podemos candidates won five seats in the European Parliament elections of 25 May 2014. Since the 2015 municipal, regional and legislative elections, Podemos is well established in the political game.

The location strategy of collective action highlights the difficulties encountered by present-day social movements in identifying 'the enemy' that people must fight against. Hessel writes: "Truly so, the reasons for outrage may seem today less clear or the world too complex. Who controls, who decides? It is not always easy to distinguish among all the currents who govern us" (2011: 14). This elusive feature of the enemy, which is an essential component of a social movement (Neveu 2002), highlights one of the keys to understanding why the Indignados swung between different scales of action. This evolution is probably similar to other mobilizations emerging in the wake of the Indignados, such as the Occupy movement in the United States. Aguiton and Haeringer have noted that "In New York, the occupiers recently struck an alliance with Occupy Our Homes, a collective for the right to housing and opened habitation squats for the poorly housed, reminding one of the practices of the Spanish activists" (2012: 9). Voss and Williams (2012) demonstrate that the focus of such movements came to lie in the construction of new collective capacities through the democratic practices implemented at the local scale rather than obtaining concessions from the state.

\section{Bibliography}

Adell Ramón. 2011. 'La movilización de los indignados del 15M. Aportaciones desde la sociología de la protesta', Sociedad y Utopía, 38: 141-70.

Aguiton Christope, Haeringer Nicolas. 2012. ' $(S$ ') occuper (de) la gauche, ou l'ignorer?' Mouvements, 69:116-27.

Alguacil Julio. 2013. 'La mobilisation citadine dans la transformation des quartiers périphériques de Madrid', in Coudroy de Lille Laurent. et al. (eds.), L'urbanisme espagnol depuis les années 1970. Rennes: PUR, 85-98. 
Arellano Javier et al. 2012. '75-M Bilbao: Estudio de dinámicas sociales en torno a las movilizaciones del 15-M en Bilbao', Vitoria Gasteiz: Servicio Central de publicaciones del Gobierno Vasco.

Auyero Javier. 2005. 'L'espace des luttes: Topographie des mobilisations collectives', Actes de la recherche en sciences sociales, 160:122-132.

Calle Ángel, Candón José. 2013. 'Sindicalismo y 15M', in Cruells M., Ibarra P. (eds.), La democracia del futuro. Del 15 M a la emergencia de una sociedad civil viva. Madrid: Icaria Editorial, 151-67.

Calvo Kerman et al. 2011. 'Movimiento 15M: ¿quiénes son y qué reivindican?', Zoom Político, Fundación Alternativas, 4: 4-17.

Conord Sylvaine. 2007. 'Usages et fonctions de la photographie', Ethnologie française, XXXVII (1): 11-22.

Della Porta Donatella (ed.). 2009. Democracy in Social Movements. Houndsmill: Palgrave.

Flesher Fominaya Cristina. 2010. 'Creating Cohesion from Diversity: The Challenge of Collective Identity Formation in the Global Justice Movement', Sociological Inquiry, 8o (3): 377-404.

Hessel Stéphane. 2011. Indignez-vous! Montpellier: Indigènes éditions.

Hetland Gabriel, Goodwin Jeff. 2013. 'The Strange Disappearance of Capitalism from Social Movement Studies', in Barker Colin. et al. (eds.), Marxism and Social Movements. Leiden/ Boston: Brill, 83-102.

Graeber David. 2009. Direct Action. An Ethnography. Edinburgh: AK Press UK.

Ibarra Pedro. 2013. 'Introducción', in Cruells M., Ibarra Pedro (eds.). La democracia del futuro. Del ${ }_{15}$ M a la emergencia de una sociedad civil viva. Madrid: Icaria Editorial, 5-15.

Juris Jeffrey S. 2012. 'Reflections on \#Occupy Everywhere: Social Media, Public Space, and Emerging Logics of Aggregation', American Ethnologist, 39 (2): 259-79.

Likki Tiina. 2012. '15M Revisited: A Diverse Movement United for Change', Zoom Político, Fundación Alternativas 11: 1-16.

Martínez Miguel Á., García Ángela. 2012. 'Ocupar las plazas, liberar los edificios'. Retrieved 2 May 2013 from http://www.miguelangelmartinez.net/IMG/pdf/15m_MARTINEZ-GARCIA_v5.pdf.

Mathieu Lilian. 2007. 'Ce que la précarité fait aux mobilisations', in Boumaza M., Hamman P. (eds.), Sociologie des mouvements de précaires. Paris: L'Harmattan: 241-257.

Merklen Denis. 2008. Quartiers populaires, quartiers politiques. Paris: La Dispute.

Merklen Denis, Pleyers Geoffrey. 2011. 'La localisation des mouvements sociaux', Cahiers des Amériques latines, 66: 25-53.

Navarro Clemente. 1999. El sesgo participativo. Córdoba: CSIC/IESA.

Neveu Érik. 2002. Sociologie des mouvements sociaux. Paris: La Découverte.

Nez Héloïse. 2012. 'Délibérer au sein d'un mouvement social: Ethnographie des assemblées des Indignés à Madrid', Participations, 3: 79-101.

- 2015. Podemos, de l'indignation aux élections. Paris: Les petits matins.

Nez Hélö̈se, Ganuza Ernesto. Forthcoming. 'Among Militants and Deliberative Laboratories: The Indignados', in Tejerina B., Perugorría I. (eds.), Crisis and Social Mobilization in Contemporary Spain: The M15 Movement. Farnham: Ashgate.

Pleyers Geoffrey. 2010. Alter-Globalization Becoming Actors in a Global Age. Cambridge: Polity Press.

—. 2011. 'Le réinvestissement de l'espace local par les mouvements mexicains: refuge après les impasses politiques ou creuset d'une nouvelle culture politique?', Cahiers des Amériques latines, 66: 39-55.

Polletta Fransceca. 2002. Freedom is an endless meeting. Chicago: The Chicago University Press.

Romanos Eduardo. 2011. 'Les Indignés et la démocratie des mouvements sociaux', Retrieved 18 November 2011 from http://www.laviedesidees.fr/IMG/pdf/20111118_romanos.pdf. 
—. 2013a. 'From Tahrir to Puerta del Sol to Wall Street: A Comparison of Two Diffusion Processes within the New Transnational Wave of Protest', Conference "Street Politics in the Age of Austerity", Montreal, February 21.

- 2013b. 'Evictions, Petitions and Escraches: Contentious Housing in Austerity Spain', Social Movement Studies. Retrieved 12 September 2013 from http://www.tandfonline.com/eprint/ HyUIngXrFWIQDx3FhVnb/full.

Voss Kim, Williams Michelle. 2012. 'The local in the global: rethinking social movements in the new millennium', Democratization, $19(2): 35^{2-77}$. 



\title{
6 The Spatial Dimensions of the Greek Protest Campaign against the Troika's Memoranda and Austerity, 2010-2013
}

\author{
Maria Kousis
}

A new economic and political landscape of contention has surfaced across local, national, and transnational spaces in the $21^{\text {st }}$ century in reaction to the impact of hard economic times on national populations (Diani and Kousis 2014). Lucid examples include the movements of real democracy, Occupy, and the Indignados participating in urban spaces both as national and transnational contentious publics (see chapter 5 in this volume; Fuster 2014: 237-242). This contention is especially visible in the southern part of the Eurozone and in particular Greece. In order to maintain global economic flows, enormous pressure was placed by international lenders and the Troika - the European Commission (EC), the International Monetary Fund (IMF), and the European Central Bank (ECB) - on southern European governments to implement harsh austerity measures and related neoliberal reforms (see chapter 2 in this volume; Diani and Kousis 2014). Given the sweeping and dramatic impact these measures had on national populations, the legislative decisions included in the Troika's Memoranda of Understanding (MoU) and the ensuing austerity policies led to intensive waves of multi-scalar mobilizations across an array of old and new spaces on Eurozone's periphery, and especially Greece.

Since 2010, protests spread across the Eurozone's more exposed old periphery regions (including Ireland), which are more susceptible to the global financial crisis (Lapavitsas et al. 2010). The 2007 crisis, however, also sparked demonstrations in northern as well as eastern European countries on labor rights and social welfare issues, unemployment, health, migration, violence, democracy, and extremist phenomena (Kriesi 2011; Beissinger and Sasse 2012). The new wave of Occupy, Indignados, anti-austerity, square/ piazza street politics has led to an abundance of literature, most of which do not systematically apply the conceptual and methodological toolkit of the social movement approach (see chapters 1 and 12 in this volume).

This vast array of multi-scalar contention within and beyond nationstates calls for the study of "spatial agency - the ways that spatial constraints are turned to advantage in political and social struggles and the ways that 
such struggles can restructure the meanings, uses, and strategic valence of space" (Sewell 2001: 52-55). Research in this area has focused on understanding spatial contexts as both resource and constraint (Ó Dochartaigh and Bosi 2010). More than two decades ago, scholars began examining the spatial dimension of social movements, with geographers such as Lefebvre (1991), Pile and Keith (1997), and Miller (2000) leading the way. The past decade also witnessed an increasing collaboration between geographers and social movement experts addressing spatiality and contention in the $21^{\text {st }}$ century (e.g. Martin and Miller 2003; Nicholls et al. 2013). Martin and Miller (2003) investigate how space is involved in the operation of the mechanisms identified by McAdam, Tilly, and Tarrow (2001); more recent followers include Sbicca and Perdue (2013). Nevertheless, it is still rare to find studies (e.g. Thornton 2012) with a systematic socio-historical empirical analysis illustrating how protests spread across space over time using geography tools such as ArcGIS.

Social movement scholars have examined space in relation to contention only since the early 200os, with pioneer works by McAdam, Tilly, and Tarrow (2001); Tilly (2000, 2003); Sewell (2001); and Auyero (2003, 2006). McAdam, Tilly, and Tarrow (2001) offer opportunities for a more situated and contextoriented study of the mechanisms and processes of contentious politics - even though they do not specify how space and place can be analyzed (but see Tilly 2003). Without explicitly linking to these mechanisms, Tilly (2000) offers five arguments on spatial aspects of contention illustrated through the geography of policing, safe places, spatial claim-making, and the control of places as stakes of contention (Tilly 2003: 221). Subsequent research has corroborated this view. By focusing on the itinerary, selection of targets, and geography of policing involved in the 1993 public employee protests in Argentina, Auyero (2003) examines how both physical and symbolic space structure influence protest. Bosi (2013) studies how the concept of safe territory can shed light on the persistence of, and disengagement from, violence by violent political organizations. Further developing his analytic tools on a spatial approach to contentious politics, Tilly proposes a two-dimensional view of spatial variation - proximity and mobility - which leads to four extreme types of mobilization: local fixed, large-scale fixed, local mobile, and large-scale mobile (2003: 222).

According to Auyero (2006), the literature on space and contention focuses on issues pointed out by Sewell (2001) and other scholars: space as a repository of social relations; built environment as opportunity and constraint in contentious politics; spatial routines; and meaningful spaces. Recent works on contentious politics in the $21^{\text {st }}$ century have 
illustrated a multi-scalar reorganization of movements from the local, regional, and national to the supra-national, which use new technologies and the emergence of global publics; they respond to similar multi-scalar spatial arenas where contested decision-making occurs (Mayer 2013). The development of electronic communications has contributed to the speed with which not only social movements (McAdam et al. 2001; Rucht 2005; Della Porta and Tarrow 2005) but also the global economic crisis have spread (Hassan 2011). Studies of this period have not only pointed out the rising importance of IT and social media in spreading protest (Rucht 2005) but also the increase in networking (Diani 2011) and the emergence of 'mega-networks' (Goldstone 2011). The waves of defensive protests in Mediterranean regions were carried out by 'mega-networks' comprised of very broad cross-class coalitions which "facilitate further mobilization by creating and linking prior, tightly-linked within-group networks to each other" (Goldstone 2011: 457). These post-2010 mobilizations may be a new, broader family of anti-austerity protests with claims to representative democracy, but there are notable divergences. It is, moreover, too early to see a significant expansion of their actions unfolding, except in the case of Greece (see chapter 12 in this volume).

Given the rarity of studies that strive to understand the dynamics of space and protests in multi-scalar arenas, this chapter offers new evidence on the spatial dimensions of the Greek campaign against the Troika memoranda and austerity measures. It simultaneously aims to contribute to the wider debate on economic and political contention, which is also spreading, and to adopt an approach used by social movements. The analysis is guided by Auyero's suggestion (2006) that future research shed light on the ways in which: a) physical space affects the origins and course of joint action, and b) particular forms of making claims and/or expressing grievances are likely to recur over time.

The section that follows offers a more focused review of the literature relevant to this chapter, which centers on the spatial features of antiausterity contention, the space-specific contention of parliamentarization (Tilly 1997), and the contention in squares and streets at the national and transnational scales. The method, analysis, and concluding sections offer a Tillian approach to the spatial and diachronic profile of the three-year-long Greek protest campaign. Special attention is given to its multi-scalar (local, national, transnational) character and its persistent use of the parliament as the key space of contention. Relying also on secondary sources, it also makes references to the safety of spaces of contention and the new meanings/ routines created in old spaces by activists of the 'movement of the squares'. 


\section{Spatial Dimensions of Economic and Political Contention}

In the last decade, we have witnessed the increasingly deep and pervasive impact of globalization in the economic, political, social, and cultural spheres, reaffirming the critical importance of structural transformations and dynamics for social movement development (Kousis and Tilly 2005; Johnston and Almeida 2006; Almeida 2008, 2010). Multi-scalar contention reflects neoliberalism's failure to deliver social protection and collective goods (Mayer 2013) on a variety of fronts ranging from the provision of health care to employment, as also seen in the more recent shift of the burden from governments and corporations to individuals far less capable of bearing them. Furthermore, regulations on businesses are being relaxed, while state power has been shifting to the private sector and transnational bodies (Sbicca and Perdue 2013).

Most of the studies on anti-austerity campaigns involving wider populations have focused on Latin American countries such as El Salvador and Costa Rica (Almeida 2010, 2012). A campaign comprises a higher level of contention involving whole populations engaged in wider struggles and is defined as sustained, organized public efforts making collective claims on target authorities, constituting one element (of three) of a social movement:

Unlike a one-time petition, declaration, or mass meeting, a campaign extends beyond any single event - although social movements often include petitions, declarations, and mass meetings. A campaign always links at least three parties: a group of self-designated claimants, some object(s) of claims, and a public of some kind. The claims may target governmental officials, but the 'authorities' in question can also include owners of property, religious functionaries, and others whose actions (or failures to act) significantly affect the welfare of many people. (Tilly 2004: 3-4)

Campaigns involving the population are a notable part of the new economic and political multi-scalar contention of the $21^{\text {st }}$ century. Protesters use old as well as new spaces of resistance and repertoires of action. The parliamentarization of contention, the urban but simultaneously national scale of square protests and street contention, as well as the transnationalization of national campaigns are all illustrated in the recent post-financial-crisis protests, especially in the case of Greece. 


\section{The Parliamentarization of Contention}

Parliament is a perennial space of contention, as seen in previous periods (Tilly 1997) as well as in more recent times (Vradis 2011; Dalakoglou 2011; Leontidou 2012; Kousis 2014). Based on the analysis of large data sets on contentious events for long periods, Tilly's initial description of the parliamentarization of British contention from 1750 to the 1830 (1997: 249) offers insights on major elements that trigger a new period of parliamentary reforms, such as those seen since 2010 in Greece:

1 parliament became the object of ordinary people's contention;

2 parliamentary action incited ordinary people's claim-making, whether directed to parliament or elsewhere;

3 issues currently being considered by parliament became more central to popular contention;

4 connections with parliament became more central in a wide range of claim-making.

Even when powerful global economic and political actors, such as the Troika with Greece, exercise overwhelming pressure on the state, the persistence of parliament-directed protest (Dalakoglou 2012; Korizi and Vradis 2012; Leontidou 2012) attests to the high significance and durability of nationallevel institutions (Della Porta and Mattoni 2014). Protesters have targeted the Greek Parliament as the most accountable national institution for securing the social welfare of the country's population.

\section{Square Camps and Street Politics in Urban and National Spaces}

A great deal of square camp and street contention occurs at the national level, forming national campaigns against neoliberal reforms and austerity policies. These protests appeared first in Latin America (Strawn 2005; Johnston and Almeida 2006; Almeida 201ob; Bellinger and Arce 2011) and Asia (Arce 2010; Arce and Kim 2011). Few are the systematic studies documenting the regional profile of such campaigns (Almeida 2012). With evidence on community mobilizations from El Salvador and Costa Rica, Almeida shows that "localities with greater levels of state and community infrastructure (highways, administrative offices, universities, NGOs and local chapters of oppositional parties) were associated with heightened collective action opposing the privatization of health care and public utilities" (Almeida, 2012: 1061). These instances of social infrastructure were the products of state-led development before the era of accelerated neoliberal globalization. 
The global financial crisis of 2007 has led to a new set of opportunities and threats for the expression of public demands in democratic as well as authoritarian contexts (Smith 2011). Since 2008, square and street politics have been rejuvenated - initially in the Arab region, the EU, and North America, with more recent manifestations in Turkey and Brazil. This is especially visible in economic and political contention under neoliberal restructuring. The influence of a Mediterranean, urban 'movement of the piazzas' at the local and global level is undeniable (Leontidou 2012). Street politics since the Arab protests reflect the important role of the regional landscape across and beyond the Mediterranean. This is reflected in activist discourse (Leontidou 2012), which mirrors the importance of spatial agency and the ways in which resistance can reshape the meanings and uses of space (Sewell 2001).

In recent years, scholars have published systematic studies on street politics in the context of the financial crisis in France (Ancelovici 2011), Greece (Diani and Kousis 2014; Kousis and Kanellopoulos 2015), EU countries (Kriesi 2011), and Eastern European countries (Beissinger and Sasse 2012). Recent work on crisis-related contention in southern Europe offers fresh evidence of square protest camp mobilizations in Spain and Portugal ('12 M', ' $15 \mathrm{M}$ ', and ' $15 \mathrm{O}$ ') as well as an analysis of the composition of $15 \mathrm{M}$ mobilizations in Spain (Baumgarten 2013; Fuster 2012; see chapter 5 in this volume). Qualitative studies focus on the urban character of $21^{\text {st }}$ century protests, pointing to a revitalization of politics with a lasting impact and the engagement of high numbers of participants imagining a different world (Madden and Vradis 2012: 235-236). In their spatial ethnographic analysis of the Indignados' protests in upper and lower Syntagma Square in June 2011, Kaika and Karaliotis (2014) point to the significance and limitations of using indignation to establish a wider democratic politics.

\section{Transnational Spaces of Contention}

The globalization of resistance was initially marked by events such as the Seattle mobilizations against the WTO, the G-8, the IMF, the World Bank, the EU, and the World Economic Forum ${ }^{1}$. This was followed by transnational activist networks of the World Social Forum and the European Social

1 Other such events include the 1988 anti-IMF and World Bank counter summit in Berlin, the 1994 Zapatista uprisings, or the protest by the People Global Action network [I thank Marcos Ancelovici for this point]. 
Forum (Della Porta 2009), which focused on global justice against neoliberal globalization and neoliberal restructuring (Bringel and Munoz 2010).

Following the multi-scalar 2007 financial crisis that was triggered in the US and the spiralling banking sector or sovereign debt crises affecting populations across the US, Europe, and other regions, both transnational and national contention has risen (Goldstone 2011; Kriesi 2011; Smith 2011; Beissinger and Sasse 2012; Fuster 2012; Shepard 2012). Contenders across transnational urban spaces are against financial, economic, and political institutions at both the transnational and national level. The most recent literature focuses on significant issues related to this new phase of transnational contention visible in Occupy and real democracy movements, such as democracy and new technologies (Flesher Fominaya and Cox 2013; Della Porta and Mattoni 2014).

The sections that follow offer a systematic protest event analysis approach that highlights the spatial features of the Greek campaign against the Troika memoranda and austerity measures: its parliamentarization as well as its urban, national, and transnational topographies and the ways in which they influence, and are influenced by, the protesters.

\section{Research Approach: Large Protest Events and the Greek Campaign against the Troika Memoranda and Austerity}

The study of contentious events is especially significant for periods of 'thickened history' when "the pace of challenging events quickens to the point that it becomes practically impossible to comprehend them and they come to constitute an increasingly significant part of their own causal structure" (Beissinger 2002: 27). It allows for the study of compact defensive actions and frames of a mobilized public confronting austerity and memorandum policies of devastating impact imposed by a delegitimized Greek state and powerful economic and political transnational agencies during the turbulent period of 2010 to 2013.

During this 'thickened' period, thousands of protests ${ }^{2}$ took place mostly at the local and national level but also on a transnational scale. Choosing the Large Protest Events (LPEs) as the unit of analysis facilitates the

2 In response to inquiries by Syriza MPs, the Minister of Public Order and Citizen Protection announced that from May 2010 to April 2014, 20,210 protests occurred across the country, 6,266 of which took place in the Attica Region which includes Athens, based on police reports. See also, http://www.apergia.gr/ for a day-to-day calendar of protests in Greece. 
systematic tracing of all key events and synchronized actions at the national level. These LPEs of the first three years of the Greek crisis were organized against the Troika's MoU and the government's related austerity policies. They constitute a national anti-austerity campaign sparked by neoliberal adjustment and austerity policies in Southern European countries. Mostly involving demonstration-marches and national strikes between January 2010 and January 2013 with claims against austerity and/or neoliberal policies, the 32 LPEs I look at in this chapter share the following features:

1 a high number of participants (minimum 5,000 - maximum 500,000);

2 a high number of parallel and synchronized events;

3 national-level claims challenging the Troika's MoU and government austerity policies;

4 broad, cross-class coalitions involving a large number of groups and the general public;

5 based in Athens' Syntagma (Constitution) Square, addressing the parliament;

6 accompanied by parallel protests in cities and towns across the country with the same claims.

Due to their potential impact, these LPEs were widely covered by national and transnational media. Thus, as with previous periods of "thickened history" (Beissinger 2002), 3 the best strategy of analysis is a "blanketing strategy" (Beissinger 1998: 290-300) utilizing multiple available sources in order to enrich the data set of more than 450 articles. ${ }^{4}$ Therefore, five major sources were selected: Eleftherotypia, ${ }^{5}$ the leftist Rizospastis, ${ }^{6}$ and Avgi $^{7}$ as well as Indymedia and real-democracy.gr. They were supplemented

3 The crisis period in Greece witnessed a rapid rise in independent electronic news and media sites. This may be compared to the transitional period witnessing the rapid development of independent newspaper sources (Beissinger 2002).

4 This chapter draws on primary data produced in part under 'Mediterranean Environment, Networks and Actions' (coordinator: M. Kousis), a project stemming from 'Mediterranean Voices: Oral History and Cultural Practices in Mediterranean Cities' with 80 per cent funding by the European Commission (DG EuropeAid, contract no. E8/AIDCO/2000/2095-05) and 20 per cent through matched funding by the University of Crete and other sources. The work by Kostas Kanellopoulos (locating media mentions and coding), Marina Papadaki (technical assistance), and Sara Karavasili (data entry) is gratefully acknowledged.

5 Over a period of more than forty years, Eleftherotypia, an independent center-left, multithematic newspaper with high circulation rates offered continuous and detailed coverage on contentious issues and social mobilizations. Unfortunately, the paper stopped operating from December 2011 to mid-January 2013 due to financial problems.

6 The official newspaper of the Greek Communist Party.

7 Newspaper supporting Syriza. 
by other Greek national news sources, e.g. To Vima, Ta Nea, Kathimerini, Epohi, tvxs, international news sources (The Guardian, Reuters, BBC), and blogs such as iskra.gr.

\section{A Multi-Scalar Anti-Austerity Campaign: From Athens' Syntagma Square to Urban Squares Within and Beyond Greece}

Three major phases stand out in the campaign (Diani and Kousis 2014). The first anti-austerity year, from February 2010 to February 2011, constitutes the starting period and was marked by waves of protest against not only the Greek government's 'stability measures' but more importantly the Troika's first memorandum and its accompanying measures, which gave rise to an escalation of strikes and intense resistance. The second period, from March 2011 to February 2012, witnessed the Multi-Purpose Act and the second memorandum. During this period, parliament approved its MidTerm Fiscal Strategy (2012-2015), which included privatizing public assets, public sector restructuring and downsizing, and more wage, personnel, and pension cuts (Markantonatou 2013). The third period took place from March 2012 to December 2012 and can be separated into two periods - one in which there were no LPEs and another in which a kind of rejuvenation of LPEs materialized. Whether the January 2013 LPE belongs to the third phase or to a new one remains to be studied based on how future protests develop.

\section{Action and Claim Repertoires across the Country and Beyond}

New networks of protesting groups were formed in Greece in reaction to harsh measures and agreements between transnational and national bodies, as illustrated in the massive protests that were organized in Syntagma Square and other squares across the country. The diachronic spread of action forms, claim-making, and new social movement actors are reflected below. Specifically, Graph 6.1 depicts the main types of action used in each LPE. These direct democratic, demonstrative, confrontational, and violent action forms escalate in the second period, that of the Greek Indignados (or the movement of the squares), from April 2011 to February 2012. It is during this period that the most notable increase took place in terms of direct democratic actions. These were carried out by very diverse groups of participants who did not claim any affiliation to political parties or other political groups. Less drastic were the changes in the pattern of demonstrative and 
confrontational actions (mostly general national strikes). Police repression and violence subsided by early June.

\section{Graph 6.1 Main Types of Action of the 32 Large Protest Events, January 2010-January 2013}

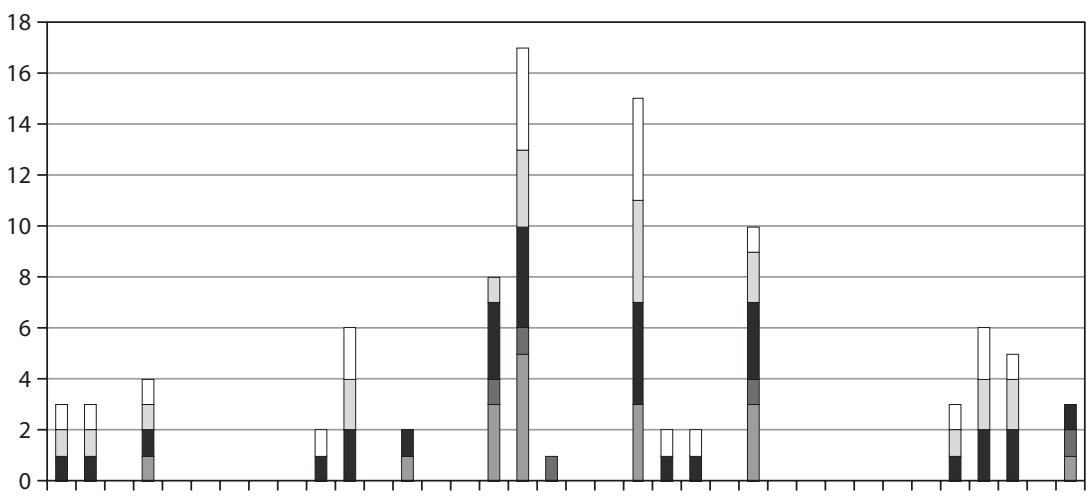

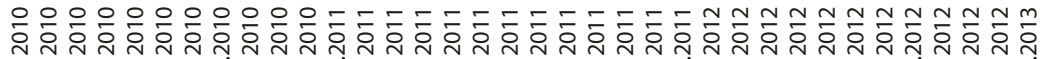

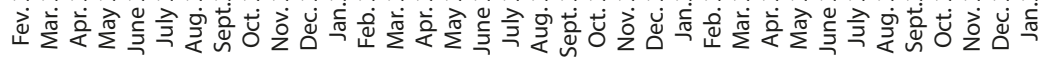

$\square$ Violent $\square$ Confrontational $\square$ Demonstrative $\square$ Petitioning $\square$ Direct Democratic

Protest claims against the Troika's MoU and the austerity policies appeared across the entire country. The protesters opposed the drastic nationwide socio-economic impact of these policies, the aim of which was to save the Eurozone and leave the global economic arena and its financial centers unharmed. Overall, the protest claims' primary targets were the Greek government (including the parliament and the police force), followed by the European Commission, the Troika, and foreign banks. Other groups that were challenged included financial institutions and credit agencies, the rich, and local government agencies. The least mentioned were capitalist markets and the G20/G8. At some events, Germany was considered a targeted state, especially since June 2011 (Kousis 2013).

The protestors' main grievances were the unprecedented neoliberal, structural adjustment laws and measures that led to dramatic cuts in wages and pensions; tax increases; the privatization of public enterprises, health, and education; and other cuts to social expenditure. These grievances reflected the protestors' serious concerns about the impact of these austerity measures on the economy, the society, and the country's sovereignty and democracy (Diani and Kousis 2014). 
Campaign protesters demanded "Taxing the Rich", job creation, and the provision of social welfare (health and education). They also called for the resignation of responsible politicians, an immediate halt to privatizations, and the annulment of the externally imposed austerity policies. Less frequently heard were demands concerning reforms to the Eurozone and EU fiscal strategies as well as elections (Kousis 2013). ${ }^{8}$

\section{Mobilizing Actors and Means of Communication}

Participation in the LPEs was initiated and organized by major conventional actors such as political parties and unions as well as new actors: the aganaktismenoi (the Greek Indignados), also known as the movement of the squares/piazzas.

The most frequently mentioned groups of protesters are presented in Table 6.1 below. Highest in frequency were the political parties of the left, with Syriza participating more frequently (in 24 of the 32 LPEs), followed by Antarsya, the Greek Communist party (KKE), the public and privatesector union confederations, anarchist/anti-authoritarian groups, as well as students and/or their parents. Groups that participated less frequently include economic or professional associations, civil society groups, and the general public. The categories with the lowest frequency were the self-employed, pensioners, artist groups, immigrant groups, soccer fan clubs, ultra-right groups, European labor unions, communities engaged in environmental conflicts against the state (e.g. Keratea), Spitha, the political movement initiated by the internationally known composer Mikis Theodorakis, the Action Group for German remunerations, Facebook groups, and others.

There was a steady increase in the types of groups and organizations participating especially in the second pre-election period, with noticeable peaks in the May-June 2011 period (the Greek Indignados), and February 2012 (Kousis 2014). While the anti-austerity campaign began with conventional/ traditional protest groups such as unions, political parties, teachers, and students, within a year, new justice-oriented groups (e.g. which had been formed in previous years to protest against paying new taxes) significantly fortified the broad coalitions of anti-austerity contention. It was also in the second year that the general public began making a stronger appearance

8 Ongoing research focuses on attributions of responsibility related to the Euro-zone crisis by all actors in the public sphere, including claims by protestors, in Greek and German newspapers as well as Reuters: http://www.ggcrisi.info/ 
Table 6.1 Participating Protest Groups, January 2010-January 2013

\begin{tabular}{lcc}
\hline Type of Participating Group & Participation in LPEs & No. of Percent \\
\hline Political Parties & 24 & $75,00 \%$ \\
ANTARSYA & 23 & $71,90 \%$ \\
DIMAR & 4 & $12,50 \%$ \\
Ecologist Greens & 2 & $6,30 \%$ \\
KKE & 22 & $68,80 \%$ \\
$\quad$ SYRIZA & 24 & $75,00 \%$ \\
GSEE/ADEDY (private \& public sector unions & 19 & $59,40 \%$ \\
$\quad$ other union and employees & 25 & $78,10 \%$ \\
other associations & 17 & $53,10 \%$ \\
$\quad$ OLME POSDEP & 20 & $62,50 \%$ \\
anti-autoritarian AK & 20 & $62,50 \%$ \\
anarchist groups & 17 & $53,10 \%$ \\
justice oriented groups \& networks & 15 & $46,90 \%$ \\
indignados & 12 & $37,50 \%$ \\
occupy & 6 & $18,80 \%$ \\
students, pupils and/or their parents & 22 & $68,80 \%$ \\
Technical/Commerce Chambers & 9 & $28,10 \%$ \\
professional org/s \& groups (doctors, & 11 & $34,40 \%$ \\
lawyers, engineers & & \\
economic interest groups (small/medium & 9 & $28,10 \%$ \\
scale) & 72 & $21,90 \%$ \\
farmers and agricultural organizations & 7 & $21,90 \%$ \\
feminist organizations and groups & 10 & $31,30 \%$ \\
other civil society organizations and groups & $56,30 \%$ \\
the general public (citizens, the population, & & \\
the Greeks, etc) & $700.00 \%$ \\
Total N of LPEs & &
\end{tabular}

in the protests (Kousis 2014). Researchers have recently just begun to study the networking and linkages among major groups that played a key role in initiating and organizing the LPEs. Most of these are political parties of the left, political networks, and union organizers (Kanellopoulos et al. 2013; Kanellopoulos 2015).

What is striking is the vital role which IT, virtual communication, and social media played in the organizing, supporting, and spreading of antiausterity protests in Greece in the past three years (Kaika and Karaliotas 2014; Leontidou 2012; Tsaliki 2012). This is especially discernible when examining the scale shift, the synchronized parallel actions, and also the interactions between the local, national, and transnational arenas of the anti-austerity campaign. 


\section{A Perennial Space of Contention: The Parliament and Syntagma Square $^{9}$}

Situated in the center of Athens, the Greek Parliament is a collection of former palace buildings that oversees Syntagma Square, which may be seen as an extension of its courtyard. It constitutes a heavily guarded environment that hosted four decades of decision-making bodies that led to huge state debts. Syntagma is a most suitable example of space as a semantically complex concept in contentious politics (Sewell 2001), as it has routinely been the square where mass demonstrations and rallies gave voice to protestors' claims and where attempts were made to influence Greek political decision-makers.

Southern European urban squares or piazzas are the product of mixed land use, informality, and street life which are similar to the agora, a public space between the private house and the public parliament, the individual and the state (Leontidou 2012). The agora as a public space of contention has deep roots. In Athens, today's Syntagma goes back to 1843, when the Greek public revolted and succeeded in forcing King Otto ${ }^{10}$ to grant them a new constitution. Since then, it has been a space of contention and negotiation between the public and the modern Greek state (Madden and Vradis 2012: 236). Some of the most significant contestations which occurred there include the 'bloody December' of 1944, which witnessed the killings of many communists and ignited the Greek civil war; the massive protests in 2007 against the catastrophic forest fires, which cost the lives of more than 80 people; the December 2008 protests against police violence and neoliberalism's effects on the younger generation, which started in the neighborhood of Exarheia as a reaction to the fatal shooting of 16 -year-old Alexis Grigoropoulos; and, of course, the large and intense anti-austerity protests, including those by the Greek movement of the squares, which followed in the footsteps of the Spanish Indignados (Leontidou 2012; Kousis 2014).

As the mediating agency, the Greek Parliament has been responsible for implementing and facilitating structural adjustment and austerity policies imposed by national and transnational actors through drastic changes of the related legal and institutional arrangements. It has also served as the

9 Leontidou (2012: 302) proposes the use of 'piazzas' instead of 'squares' to emphasize "the open and the nodal centre of material and virtual communication rather than an enclosed square and its defined landscape".

10 Son of King Louis I of Bavaria. 
political arena for all major governing parties whose policies and reforms shaped the national conditions directly or indirectly responsible for the crisis.

Although all of the LPEs against the MoU, austerity, and liberal restructuring include demonstrations and/or Indignados events which took place on Syntagma Square, three spatial routines can be distinguished which took place in the center of Athens. The thirteen general strikes usually began their marches at different times, from three different sites connected to their organizers, but all ended up on Syntagma Square. Participants from the General Confederation of Greek Workers (GSEE) started from Alexandras and Patision Avenue, the location of GSEE's headquarters. The coordinating committee of the primary level unions (involving the non-parliamentary left) began from the Museum further down Patision Avenue. Finally, the communist party unions (PAME) started from Omonoia Square at the end of Patision Avenue - they adopted tight tactics that did not allow intruders to disrupt their nonviolent march. Other than the Indignados LPEs, the starting point for the rest of the LPEs was Propylaia, i.e. the entrance of the old building of the University of Athens which used to be protected by university asylum laws and which was established as the starting point of protests in the contentious decade of the 1960 s and has continued to be so up to this day. ${ }^{11}$ The two main opposite routes of the marches (from Patision and Propylaia) led to the Syntagma Square demonstrations. ${ }^{12}$

\section{New Meaningful Practices in Old Spaces: The Movement of the Square (Greek Indignados)}

The first call for a meeting of Greek Indignados was uploaded on Facebook on 20 May 2011 at the White Tower in Thessaloniki. This was followed by many calls leading to meetings in 38 Greek cities on 25 May (Giovanopoulos 2011; Gazakis and Spathas 2011). It is estimated that between 25 May and 30 July 2011, the number of people visiting Syntagma Square ${ }^{13}$ may have reached 2.6 million (Leontidou 2012). It had been decades since so many Greek citizens had taken to the streets and made their views known in public

11 I would like to thank Kostas Kanellopoulos for his input on these old and new protest routines.

12 See illustration of Syntagma Square march and demonstration of 19 October 2011 in http:// alepouda.blogspot.gr/2011/10/19-2011.html; it offers the estimated number of participants of the LPE of 19 October 2011 by comparing it to the capacity of the OAKA stadium.

13 In http://xilapetres.blogspot.gr/2011_06_01_archive.html, see a panopticon view of Syntagma Square's related LPE of 29 May 2011. 
spaces, surpassing old political party identities (Stavrou 2011). Although innovative alternative actions intertwining culture and direct democratic politics were put forth during this period, a duality emerged. From May to June 2011, through Facebook and other social media calls, a new type of group began to appear in Syntagma and central squares or landmarks of most Greek cities. Known as the aganaktismenoi, this group was heavily influenced by the Spanish Indignados (Giovanopoulos and Mitropoulos 2011; Korizi and Vradis 2012; Leontidou 2012). Blaming political parties for the country's critical condition and at the same time demonstrating their contempt for the parliament (Tzanelli 2011), they rejected political party affiliations and opted instead for peaceful events and actions. This prompted thousands of citizens across different classes, age groups, and political beliefs to join the two-month-long protest camp set up in front of the Greek Parliament. Similar protest camps were soon being set up across many Greek cities (Kousis 2014). Their views were reflected in the banners, posters, and placards displayed on the upper and lower parts of Syntagma Square. A related content analysis $(\mathrm{N}=178)$ of these views between 25 May 2011 and 30 July 2011 reveals that one-fifth (21.3 per cent) targeted the Troika (e.g. "we don't owe, we won't pay", "no to world government, national independence", "we support Syntagma Square, won't leave until the government, Troika and the debt go" (Petropoulos 2014). This was followed by 16.2 per cent targeting the prime minister, the vice president, and governing parties, and 11.8 per cent targeting all (or almost all) MPs and parliamentary parties or party leaders (Petropoulos 2014). The remaining 42.7 per cent of the banners, posters, and placards referred to mobilization calls, platforms, tactics, links, needs, and activities of the movement of Syntagma Square (Petropoulos 2014).

Ethnographic research on Athens' Syntagma Square camp reveals "a consensual and deeply spatialized staging of dissent ... with internally conflicting and often radically opposing political imaginaries" (Kaika and Karaliotas 2014: 2). Syntagma's more ethnocentric, conservative and rightoriented but angrier upper square was notably different from the more progressive, left-oriented, and alternative lower square. While the upper part attracted demonstrators with more patriotic, nationalist, xenophobic, religious, and populist claims, the lower part - besides hosting the camp - established a direct-democratic-oriented agora of highly committed activists, many of whom derive from radical parties of the left (Stavrou 2011; Petropoulos 2014; Kaika and Karaliotas 2014; Leontidou 2012; Tsaliki 2012). The activities of the upper and lower square accordingly varied widely. The upper part hosted groups such as 'The Greek Mothers', the '30o Greeks', 
and priests. By contrast, the lower part of Syntagma was used by activists to project films/documentaries, host a first aid medical unit of volunteer doctors, connect with activists outside of Greece through the internet, distribute food offered by restaurants, and act as information point for those in need of services (Petropoulos 2014). Other collective self-organizing practices included clothes exchanges, garbage collection, and performing arts events (Kaika and Karaliotas 2014).

More importantly, lower square groups organized Open Popular Assemblies every evening with procedures that allowed an equal voice to all, aiming towards real and direct democracy (Kaika and Karaliotas 2014: 9). As a result of the above, the movement of Syntagma Square and its satellites across the country succeeded in offering a space for voicing one's views as well as for imagining and materializing alternative ways of existing together. ${ }^{14}$ Furthermore, it transcended its spatial boundaries through steady (internet) connections with similar movements across the globe (Kaika and Karaliotas 2014; Petropoulos 2014).

\section{The (Non-)Safety of Syntagma Square}

Although Syntagma Square has been a perennial space of resistance that has for the most part been peaceful, it has not always been a safe place for protesters. Given its key location in front of the parliament and the very high numbers of protesters, it was between 2010 and 2013 the space that witnessed the highest levels of violence in the Greek anti-austerity campaign in comparison to its other spaces of contention.

This was particularly true on 28 and 29 June 2011 following the seventh national strike. Expressing their strong opposition to the Troika's second bailout package of 21 June 2011 and the measures associated with it, the large union confederations united with the square movement and blockaded parliament using nonviolent tactics to prevent MPs from passing austerity and bailout-related legislative measures. After peaceful protests, violence erupted and mass violent confrontations occurred (Sotirakopoulos and Sotiropoulos 2013; Petropoulos 2014) in which protesters faced high levels of police repression and tear gas. ${ }^{15}$ Amnesty International (2011) as well as the

14 Current research focuses on alternative solidarity initiatives that have surfaced especially since 2011 across the country; to some extent they have been influenced by these protests http:// www.livewhat.unige.ch/?p=152.

15 A related inquiry, "The four-year chemical war against protesters", was submitted in parliament by Syriza MPs in March 2013. 
medical and hospital associations called on the Greek state to restrain police repression. Parliament's subsequent approval of the austerity measures led to significant reductions in the number of people participating in the demonstrations (Leontidou 2012).

Similar but somewhat lower peaks in violence and types of major actions followed in the LPEs in October 2011 and February 2012 in reaction to later Troika mandates and government measures. Although fewer in number, these major protest events were very intense and well-attended, including the tenth national 48-hour strike. The February 2012 LPE resulted in an unprecedented level of intensity of action and significant property damage in the area surrounding Syntagma Square (Kousis 2014).

Throughout this period, parliament was heavily protected by the police. Indeed, since 2011 - the second phase of the campaign of the Greek Indignados - the parliament buildings were equipped with permanent protective iron railings to prevent protesters from reaching them. The railings were removed a few days after the new Syriza government took office at the end of January 2015.

\section{Invigorating National Spaces of Contention: Squares and Streets of Cities and Towns Across the Country}

Even though Syntagma Square constitutes a central and exceptional political space, synchronized, parallel, and sustained protest events were carried out across a large number of cities and towns throughout the entire country, usually in front of the city's municipal hall and/or central square.

As depicted in Graph 6.2, for each of the 32 LPEs that took place in Athens, the protest campaign was also carried out across a majority of Greek towns and cities.

Thus the 32 major events, most of which ended in demonstrations facing the Greek Parliament in Athens' Syntagma Square, were accompanied by a total number of 1,069 parallel protest events across the country, all with the same repertoire of claims. The graph illustrates the national character of an anti-austerity campaign linked to the 32 LPEs over the three-year period.

How protest events spread across space over time is a subject that has not been studied using geographic information system maps, as evidenced by the few works on this subject matter (Thornton 2012). The map that follows is constructed with the dataset of LPEs from January 2010 to December 2012.

Map 6.1 below illustrates the participation of Greek cities and towns across the three major phases of the campaign. It should be noted that the 


\section{Graph 6.2 Number of Greek Cities and Towns Participating in the 32 LPEs, January 2010-January 2013}

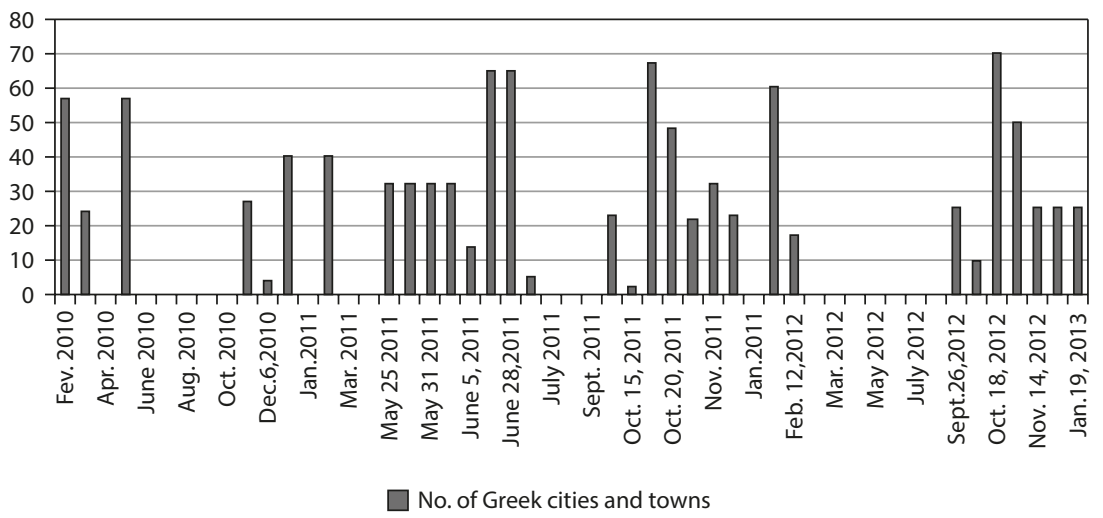

map only depicts the minority of cases for which the articles mentioned the names of the cities or towns. It does not include the majority, i.e. the unnamed cities and towns which were only mentioned in numbers. Although local level data were not available for this analysis, according to police records, some 20,210 protests were carried out in Greece from May 2010 to April 2014.

The first phase of protests, from February 2010 to February 2011, was sparked across the country following the Troika's first MoU and the accompanying measures. These began as general strikes and rallies against the Greek government's stability measures carried out in Athens and other cities. The protestors were initially public sector employees but in March they were joined by trade union confederations of both private and public sector employees. A third national strike and demonstrations across the country took place on 5 May 2010 following the downgrading of Greece's main debt rating to junk status (BB+) by Standard and Poor's and the first Greek bailout package (110 billion euros, the highest ever given to a country). The protesters demonstrated against the Greek government's pledges to implement the Troika's first MoU. This day was marked by the death of three employees of a bank when petrol bombs were thrown into the building they were working in. Politicians were harshly criticized in public. Violence was clearly escalating.

The second phase witnessed the most important increase in the participation of towns and cities across the country. This was in reaction to the Multi-Purpose Act and the second Troika MoU that included privatizing public assets, public sector restructuring and downsizing, and more cuts 
Map 6.1 Total Number of LPEs by Phase of the Anti-Austerity Campaign in Greek Cities and Towns, January 2010-December 2012

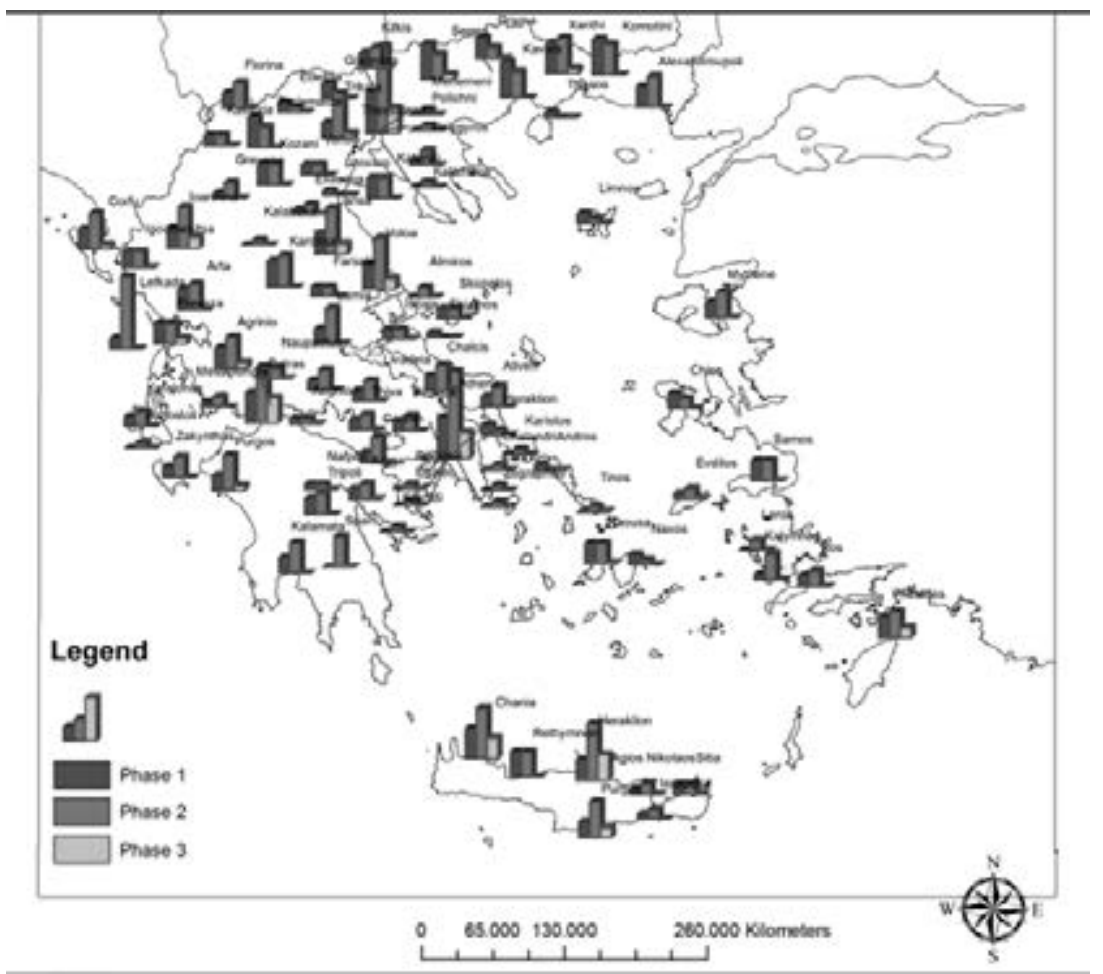

in wages, personnel and pensions (Markantonatou 2012). Following the Facebook call of 20 May 2011, squares in 38 cities took on a new function - that of a protest camp. Tens of thousands signed to attend protests in the squares of Greek cities. Protesters also organized events in Athenian neighborhood squares (Mpresta 2011: 91-93). During the second phase in the summer of 2011, square protests reached a peak, especially on 28 and 29 June. A similar peak was reached at LPEs that took place on 5, 19, and 20 October 2011 in protest against the Troika's third Greek bailout package of 'hard restructuring' (27 October 2011).

Greek cities and towns continued to participate in the campaign in the winter of 2011 (see also Graph 6.3) following more austerity conditions set by the Eurogroup and the Troika. As Map 6.1 illustrates, there was a notable decrease in the participation of Greek cities and towns in the third phase (in green), i.e. from March 2012 to December 2012. This is in part due to a drop in the number of protest events surrounding the first national elections 
held since the outbreak of the economic crisis. In these elections, the two ruling parties that had dominated Greece's postdictatorial period suffered significant losses, especially the incumbent Pasok, with many votes going to new parties such as Syriza (Coalition of the Left) and the extreme-right Golden Dawn (Kousis and Kanellopoulos 2014).

Cities and towns across the country continued to participate in parallel LPEs against further austerity and neoliberal packages in September and in October against measures related to the release of funds by creditors under the second bailout agreement (Monastiriotis 2013). The new measures included more cuts to social benefits, pensions, and salaries as well as further increases in fuel taxes and new taxes for all income categories (immensely impairing the poor and the self-employed) including businesses (Monastiriotis 2013). In response to the above, seven large protest events took place: three national general strikes by public and private sector workers, one workers' rally, two national general work stoppages (one of which was part of the European Trade Union Confederation's first strike against austerity) and one march commemoratimg the university student uprising against the military junta.

For the first time in Greece's postwar history, individual citizens who were not linked to the major organizations leading the protests (e.g. trade unions or left-wing political parties) were heavily represented in the 'occupation' of squares across the country. In most of these squares, coordinating groups were formed that met on a daily or weekly basis, discussing local issues of grave concern such as the selling of ports or gold mines, or the degradation of health services. Minutes were taken at such meetings. Musical and cultural events took place, following the blueprints of happenings and the operating style of Syntagma's groups. Syntagma's websites (real-democracy.gr and amesi-dimokratia.org) were linked to the public assemblies of Greek cities and towns via Facebook and blogs. On occasion, non-Athenian activists visited Syntagma (Mpresta 2011: 94-100). Older memories were revived, as reflected in the slogan 'bread, education, liberty: the [military] junta did not end in 1973' (Axelos 2011: 203).

\section{New Global Cities of Contention: Transnationalizing the Greek Campaign}

The campaign against the Troika's MoU and neoliberal policies eventually moved beyond Greece's borders (Tsomou 2011; Kousis 2013). Five of the 32 LPEs examined here were part of mega-transnational protest events 
carried out in cities across Europe, North America and other regions. This transnationalization began in the second phase of the campaign in 2011, when Greek protesters joined the European Revolution of 29 May across numerous European cities and the 'United for Global Change' event by Occupy movements across 951 cities on 15 October (Kousis 2014). This was followed by a day of transnational solidarity for Greece on 18 February 2012, with 19 European and North American cities participating. Solidarity actions targeted Greek embassies and IMF offices (Kousis 2014). And on 14 November, Greek protesters on Syntagma Square and in 25 Greek cities participated in the European Trade Union Confederation's first strike against austerity, which took place across 250 cities.

At the end of the third phase of the campaign, economic contention took a new twist. The largest anti-fascist protest event in recent decades in Greece was organized on 19 January 2013, two days following the killing of a Pakistani immigrant. The protest spread to 26 non-Greek cities. Another very significant transnational event took place on 14 June 2013 after the prime minister announced that the government would be shutting down the historical public broadcasting service (ERT) as a direct result of the Troika's MoU and the government's austerity policies.

\section{Graph 6.3 Number of Non-Greek Cities (in red) Participating in the 32 LPEs, January 2010-January 2013}

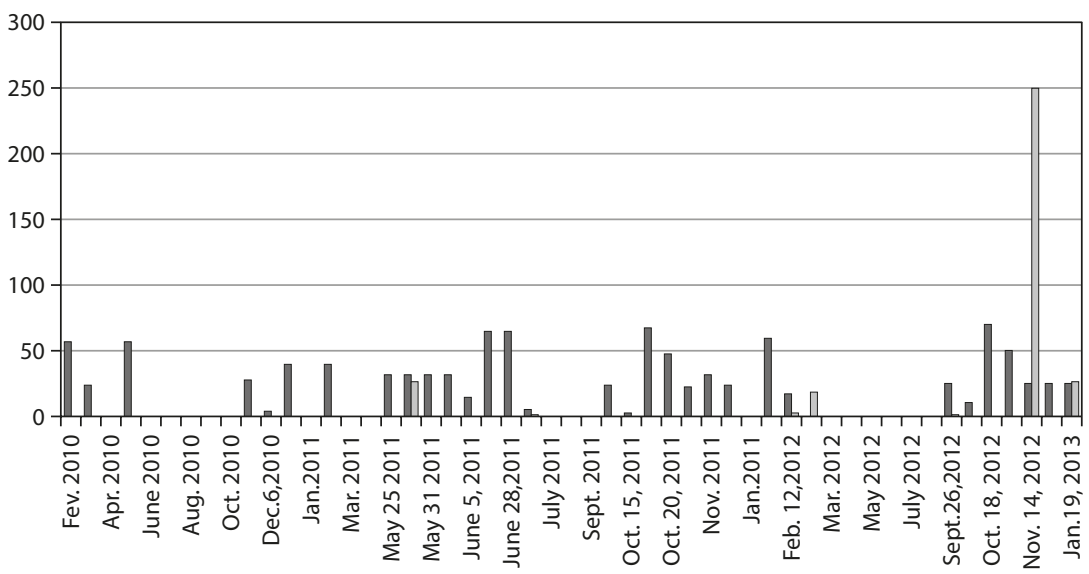

No. of Greek Cities $\square$ No. of NonGreek Cities

Note: The 15 October 2011 LPE is not depicted here, given the very large number of participating cities (951). 
According to the data at hand, there was only one transnational event (in London) during the first phase of the campaign, as can be seen in Graph 6.3. In the second and third phases, however, there was an increase in the number of participating cities in southern Europe (Rome, Bologna, Milan, Genoa, Madrid, Barcelona, Lisbon, and Nicosia), northern Europe (Paris, Bastille, Lyon, La Roche, Marseille, Berlin, Brussels, Amsterdam, Copenhagen, London, and Edinburgh) and other cities (Bangkok, New York, Chicago, Los Angeles) (Kousis 2014).

This chapter has applied a social movement's approach to examining the spatial dimension of the Greek campaign that surfaced following multiscalar decision-making on the Greek crisis in the Eurozone. The analysis of large protest events, or LPEs, documents a nationwide, multi-scalar struggle (Mayer 2013) against the harsh neoliberal reforms and austerity measures, which eventually led to transnational protests. The data examined in this chapter feature the three-year-long anti-austerity campaign involving higher levels of contention and whole populations engaged in wider struggles by very diverse protest groups making collective claims on target authorities (Tilly 2004).

The analysis offers a preliminary exploration of space as 'a semantically complex concept' (Sewell 2001). It does so by highlighting: a) the parliamentarization of contention (Tilly 1997); b) the new meanings and practices attached to Syntagma Square and its satellites across the country; c) the (non-)safety of spaces of contention (Tilly 2003; Bosi 2013); and d) the multi-scalar character (Mayer 2013) of the campaign against austerityinducing economic policies by the European Commission, the European Central Bank, and the International Monetary Fund as well as by three consecutive Greek governments creating and implementing the related policy instruments.

Following Auyero's suggestion for future research (2006), the analysis at hand addressed ways in which physical space affects the origins and course of joint action, especially through the parliamentarization of anti-austerity contention. As a space where protesters can directly address the parliament, Syntagma Square is an exemplary and durable space of resistance that offers opportunities for peaceful protests and the creation of new meanings and new spatial routines. Yet it is also transformed into a constraint for resistance, decreasing protest participation due to high levels of police repression and tear gas on dates of critical parliamentary decisions. 
The data illustrates a three-tier spatial arena: 1) a perennial arena at Syntagma Square documenting a sustained yet continuously adjusting parliamentarization of contention (Tilly 1997);2) a nationwide spatial arena visible in cities and towns across the country's regions; and 3) a transnational arena across the European Union and, eventually, across the globe. In the first two spatial arenas, resource-poor protesters offered alternative meanings and strategic uses of spaces available to them. In this manner, they produced new meanings of space (Sewell 2001; Auyero 2006) across the nation's streets and squares, as best illustrated in the second phase of the campaign with the movement of the squares visible across urban and rural regions. The urban character of the $21^{\text {st }}$ century protests is apparent in all three spatial arenas, attesting to a revitalization of politics and the engagement of greater numbers of participants with different visions of how the world should be (Leontidou 2012; Madden and Vradis 2012).

The multi-scalar protests have been facilitated by communication through IT and social media technologies, which may affect the centrality of proximity (Tilly 2003) to a much greater extent than in the past. They were also enhanced through 'mega-networks', comprised of very broad cross-class coalitions facilitating, creating, and linking groups and networks (Goldstone 2011) not only across Greek cities and towns but also beyond national borders. More importantly, however, the nationwide protests were supported by social linking and networking of political groups acting at the national level, especially political parties of the left and trade unions. This was evident in Syriza's steady participation in 24 of the 32 LPEs (75 per cent), its rising importance in the 2012 elections, and its electoral victory in January 2015. As Dufour, Nez, and Ancelovici posit in this volume, as in other crisis-related protest waves, the political is no longer autonomous from the economy, and economic policy is a significant factor influencing social movements. Further study is needed, however, on the relationship between space, the Greek economy, and contention. While economic conditions for the general population are worsening, since February 2013, the multi-scalar campaign has subsided, while smaller and more specialized protests are carried out with considerably fewer participants in local spaces.

The economic and political contention in Greece may be considered as belonging to the family of national anti-austerity protests (see chapters 1 and 12 in this volume) which took place in Latin America (Auyero 2003; Johnston and Almeida 2006; Almeida 2007, 2010, 2012; Arce 2010; Arce and Kim 2011). However, in contrast to these, the contention arising in the Greek case and the global political attention it has received move above and beyond the EU as a transnational space of opportunities and threats which has mostly 
referred to liberalization policies (Imig and Tarrow 2001). It illustrates a shift towards the importance of the financial sector and the impacts of the financial crisis of an ever more interdependent multi-scalar global economic and political arena, eventually involving most economies of the globe. The significance of national and regional spaces as durable spaces of contention due to multi-scalar policies affecting whole populations is therefore enhanced. Whether these spaces will maintain their contentious features vis-à-vis an increasingly empowered transnational spatial arena remains a question for future research (Tilly 2004).

\section{Bibliography}

Almeida Paul D. 2007. 'Defensive Mobilization: Popular Movements against Economic Adjustment Policies', Latin American Perspectives, 34 (3): 123-139.

- 2008. 'The Sequencing of Success: Organizing Templates and Neoliberal Policy Outcomes', Mobilization, 13 (2): 165-187.

- 2010. 'Globalization and Collective Action', in Leicht K.T., Jenkins J.C. (eds.), Handbook of Politics: State and Society in Global Perspective. London: Springer, 305-325.

—. 2012. 'Subnational Opposition to Globalization', Social Forces, 90 (4): 1051-1072.

Amnesty International. 2011. 'Greece urged not to use excessive force during protests', http:// www.amnesty.org/en/news-and-updates/greece-urged-not-use-excessive-force-duringprotests-2011-06-16 (published 16 June, accessed 20 February 2014).

Ancelovici Marcos. 2011. 'In Search of Lost Radicalism: The Hot Autumn of 2010 and the Transformation of Labor Contention in France', French Politics, Culture \& Society, 29 (3): 121-140.

Arce Moisés. 2010. 'Parties and Social Protest in Latin America's Neoliberal Era', Party Politics, 16 (5): 669-686.

Arce Moisés, Kim Wonik. 2011. 'Globalization and Extra-Parliamentary Politics in an Era of Democracy', European Political Science Review 2 (3): 253-278.

Axelos L. 2011. 'Bread, education, liberty: the junta did not end in 1973' (in Greek), in Giovanopoulos Christos, Mitropoulos Dimitris (eds.), Democracy under Construction: From the Streets to the Squares. Athens: A/synechia, 203-210.

Auyero Javier. 2003. 'The Geography of Popular Contention: An Urban Protest in Argentina', Canadian Journal of Latin American and Caribbean Studies, 28 (55-56): 37-70.

—.2006, 'Spaces and places as sites and objects of politics', in Goodin R.E., Tilly C. (eds.), Oxford Handbook of Contextual Political Analysis. Oxford: Oxford University Press, 564-578.

Baumgarten Britta. 2013. 'Geração à Rasca and beyond: Mobilizations in Portugal after 12 March 2011', Current Sociology, 61 (4): 457-473.

Beissinger Mark. R. 1998. 'Nationalist Violence and the State: Political Authority and Contentious Repertoires in the Former USSR', Comparative Politics, 30 (4): 401-422.

- 2002. Nationalist Mobilization and the Collapse of the Soviet State. Cambridge: Cambridge University Press.

Beissinger Mark R., Sasse Gwendolyn. 2012. 'An End to Societal Patience? The Economic Crisis and Political Protest in Eastern Europe', Nuffield's Working Papers Series in Politics. Retrieved 10 January 2013 from http://www.nuffield.ox.ac.uk/politics/papers/2012/Beissinger_and_Sasse_working_paper_2012_o1.pdf. 
Bellinger Jr. Paul T., Arce Moisés. 2011. 'Protest and Democracy in Latin America's Market Era', Political Research Quarterly, 64 (3): 688-704.

Bosi, Lorenzo. 2013. Safe Territories and Violent Political Organizations, Nationalism and Ethnic Politics, 19 (1): 80-101.

Dalakoglou Dimitris. 2011. 'The Square as political-spatial innovation' (in Greek), in Giovanopoulos Christos, Mitropoulos Dimitris (eds.), Democracy under Construction: From the Streets to the Squares, Athens: A/synechia, 101-110.

—. 2012. 'Beyond Spontaneity', City: Analysis of urban trends, culture, theory, policy, action, 16 (5): 535-54.

Della Porta, Donatella (ed.). 2009. Another Europe: conceptions and practices of democracy in the European social forums. London: Routledge.

Della Porta Donatella, Mattoni Alice (eds.). 2014. Spreading Protests in Social Movements of the Crisis. Colchester: ECPR Press.

Della Porta Donatella, Tarrow, Sidney (eds.). 2005. Transnational Protest and Global Activism. New York: Rowman and Littlefield.

Diani Mario. 2011. 'Networks and Internet into Perspective', Swiss Political Science Review, 17 (4): 469-474.

Diani Mario, Kousis Maria. 2014. 'The Duality of Claims and Events: The Greek Campaign against Troika's Memoranda and Austerity, 2010-2012', Mobilization, 19 (4): 489-507.

Flesher Fominaya Cristina, Cox Laurence (eds.). 2013. Understanding European Movements: New Social Movements, Global Justice Struggles, Anti-Austerity Protest. London: Routledge.

Fuster Morell Mayo 2012. 'Composition of 15M Mobilization in Spain: Free Culture Movement a layer of 15M ecosystem movement', Social Movement Studies, 11 (3-4): 386-392.

Gazakis Antonis, Spathas Vangelis. 2011. 'The People in the Square Teach Democracy: The Indignados Movement in the White Tower Square' (in Greek), in Giovanopoulos C., Mitropoulos D. (eds.), Democracy under Construction: From the Streets to the Squares, Athens: A/ synechia, 101-110.

Giovanopoulos Christos. 2011. 'Indignant with the Mass Communication or revolution in the Media? between the digital and real "market”!' (in Greek), in Giovanopoulos Christos, Mitropoulos Dimitris (eds.), Democracy under Construction: From the Streets to the Squares. Athens: A/synechia, 227-267.

Giovanopoulos Christos, Mitropoulos Dimitris (eds.). 2011. Democracy under Construction:From the Streets to the Squares. Athens: A/synechia.

Goldstone Jack A. 2011. 'Cross-class Coalitions and the Making of the Arab Revolts of 2011', Swiss Political Science Review, 17 (4): 457-462.

Hassan Robert. 2011. 'The Speed of Collapse: The Space-Time Dimensions of Capitalism's First Great Crisis of the $21^{\text {st }}$ Century', Critical Sociology, 37 (4):385-402.

Imig Doug, Tarrow Sidney. 2001. 'Studying Contention in an Emerging Polity”, in Imig Doug, Tarrow Sidney (eds.), Contentious Europeans: Protest and Politics in an Emerging Polity. London: Rowman \& Littlefield Publishers: 3-26.

Johnston Hank, Almeida Paul D. (eds.). 2006. Latin American Social Movements: Globalization, Democratization and Transnational Networks. Oxford: Rowman \& Littlefield Publishers.

Kaika, Maria, Karaliotas Lazaros. 2014. 'The spatialization of democratic politics: Insights from Indignant Squares', European Urban and Regional Studies. DOI: 10.1177/og69776414528928.

Kanellopoulos Kostas. Forthcoming. 'Collective Action Networks and Contentious Politics in Greece during the Crisis, 2010-2012: Theoretical Issues and Research Practices' (in Greek), Greek Sociological Review. 
Kanellopoulos Kostas et al. 2013. 'Alliance building in the Greek anti-austerity campaign, 20102012', $7^{\text {th }}$ ECPR General Conference, Bordeaux, 4-7 September.

Korizi Sissi, Vradis Antonis. 2012. 'From innocence to realisation', City: analysis of urban trends, culture, theory, policy, action, 16 (1-2): 237-242.

Kousis Maria. 2013. 'The Greek Protest Campaign against Troika Memoranda and Austerity Policies' (in Greek), Greek Sociological Review, 1: 33-40.

-. 2014. 'The Transnational dimension of the Greek Campaign against Troika Memoranda \& Austerity Policies, 2010-2012', in Della Porta Donatella, Mattoni Alice (eds.), Spreading Protests in Social Movements of the Crisis. Colchester: ECPR Press, 139-170.

Kousis Maria, Kanellopoulos Kostas. 2014. 'The impact of the Greek Crisis on the Repertoire of Contentious and Conventional Politics, 2010-2012', Proceedings of the $7^{\text {st }}$ Midterm International Conference of the 'Disaster, Conflict and Social Crisis Research Network, European Sociological Association.

Kousis Maria, Tilly Charles. 2005. 'Introduction', in Kousis M., Tilly C. (eds.), Economic and Political Contention in Comparative Perspective. Boulder, Colorado: Paradigm Publishers: 1-14.

Kriesi Hanspeter. 2011. 'The political consequences of the financial and economic crisis in Europe: electoral punishment and popular protest', Oxford paper, version 3, November.

Lapavitsas Costas et al. 2010. 'Eurozone crisis: beggar thyself and thy neighbour', Journal of Balkan and Near Eastern Studies, 12 (4): 321-372.

Lefebvre Henri. 1991 [1974]. The Production of Space. Cambridge, MA: Blackwell.

Leontidou Lila. 2012. 'Athens in the Mediterranean 'movement of the piazzas' Spontaneity in Material and Virtual Public Spaces', City: Analysis of urban trends, culture, theory, policy, action, 16 (3): 299-312.

Madden David J., Vradis Antonis. 2012. 'Introduction to cities in upheaval: From Athens to Occupy and back', City: Analysis of urban trends, culture, theory, policy, action, 16 (1-2):235-236.

Markantonatou Maria. 2013. 'Diagnosis, Treatment, and Effects of the Crisis in Greece: A "special case" or a "test case?"', MPIfG Discussion Paper, 13/3. Retrieved 10 January 2014 from http:// www.mpi-fg-koeln.mpg.de/pu/mpifg_dp/dp13-3.pdf.

Martin Deborah G., Miller Byron. 2003. 'Space and Contentious Politics', special issue Space, Place and Contentious Politics, Mobilization 8 (2): 143-156.

Mayer Margit. 2013. 'Multiscalar Mobilization for the Just City: New Spatial Politics of Urban Movements', in Nicholls Walter et al. (eds.), Spaces of Contention: Spatialities of Social Movements. Farnham: Ashgate.

McAdam Doug et al. 2001. Dynamics of Contention. Cambridge and New York: Cambridge University Press.

Miller Byron. 2000. Geography and Social Movements. Minneapolis: University of Minnesota Press.

Monastiriotis Vassilis. 2013. 'Austerity Measures in Crisis Countries. Results and Impact on Mid-term Development', Forum, Intereconomics, 8 (1): 1-32. Retrieved 10 January 2014 from http://www.ceps.eu/system/files/article/2013/o2/Forum.pdf.

Mpresta Marina. 2011. 'The Whole of Greece as one Square (?)', in Giovanopoulos Christos, Mitropoulos Dimitris (eds.), Democracy under Construction:From the Streets to the Squares. Athens: A/synechia, 91-100.

Nicholls Walter et al. (eds.) 2013. Spaces of Contention: Spatialities and Social Movements. Farnham: Ashgate.

Ó Dochartaigh Niall, Bosi Lorenzo. 2010. 'Territoriality and Mobilization: The Civil Rights Campaign in Northern Ireland, Mobilization, 15 (4): 405-424. 
Petropoulos Nicholas P. 2014. 'A Sociopolitical Profile and Political Impact of the Greek Indignados: An exploratory study', Proceedings of the $7^{\text {st }}$ Midterm International Conference of the 'Disaster, Conflict and Social Crisis Research Network' of the European Sociological Association.

Pile Steven, Keith Michael. 1997. Geographies of Resistance. London: Routledge.

Rucht Dieter. 2005. 'The Internet as a New Opportunity for Transnational Protest Groups', in Kousis Maria, Tilly Charles (eds.), Economic and Political Contention in Comparative Perspective. Boulder, Colorado: Paradigm Publishers, 70-88.

Sbicca Joshua, Perdue Robert Todd. 2013. 'Protest Through Presence: Spatial Citizenship and Identity Formation in Contestations of Neoliberal Crises', Social Movement Studies, 13 (3): 309-327.

Sewell, Jr. H. William. 2001. 'Space in Contentious Politics', in Aminzade Ronald et al., Silence and Voice in the Study of Contentious Politics. Cambridge: Cambridge University Press, 51-88.

Shepard Heim Benjamin. 2012. 'Labor and Occupy Wall Street: Common Causes and Uneasy Alliances', WorkingUSA: The Journal of Labor and Society, 15 (1):121-134.

Smith Jackie. 2011. 'Globalizations Forum on Middle East Protests: Commentary', Globalizations, $8(5): 655-659$.

Stavrou Angelo. 2011. "The "Upper Square" or, When the Masses Speak "Oe, Oe, Oe, Get Up from the Couch"', in Giovanopoulos C., Mitropoulos D. (eds.), Democracy under Construction:From the Streets to the Squares. Athens: A/synechia, 23-30.

Strawn D. Kelly. 2005. 'Political process, economy, and protest in Mexico, 1999-2000: An event centered quantitative analysis of collective Action in a structural adjustment society', $\mathrm{PhD}$ thesis, Sociology, University of Wisconsin-Madison.

Thornton M. Patricia. 2012. 'Mapping dynamic events: Popular contention in China over space and time', Annals of GIS, 18 (1): 31-43.

Tilly Charles. 1997. 'Parliamentarization of popular contention in Great Britain, 1758-1834', Theory and Society, 26 (2-3): 245-273.

-. 2000. 'Spaces of contention', Mobilization, 5 (2): 135-159.

-. 2003. 'Contention over Space and Place', Mobilization, 8 (2): 221-226.

-. 2004. Social Movements, 1768-2004. London: Paradigm Publishers.

Tsaliki Liza. 2012. "The Greek "Indignados": The Aganaktismeni as a case study of the "new repertoire of collective action"', In/compatible publics:Publics in Crisis-Production, Regulation and Control of Publics' panel, Transmediale Media Art Festival, Berlin, 31 January-5 February.

Tsomou Margarita. 2011. 'Zoom out: the Squares of Greece Abroad', in Giovanopoulos Christos, Mitropoulos Dimitris (eds.), Democracy under Construction: From the Streets to the Squares. Athens: A/synechia, 110-126.

Tzanelli Rodanthi. 2011. "Take Five": understanding Greek manifestations of "disrespect"' openDemocracy. Retrieved 10 January 2013 from http://www.opendemocracy.net/rodanthitzanelli/\%E2 $\% 80 \% 98$ take-five $\% \mathrm{E} 2 \% 80 \% 99$-understanding-greek-manifestations-of$\%$ E2\%80\%98disrespect $\%$ E2\%80\%99.

Vradis Antonis. 2011. 'Terminating the Spatial Contract', in Giovanopoulos Christos, Mitropoulos Dimitris (eds.), Democracy under Construction: From the Streets to the Squares. Athens: A/ synechia, 211-218. 



\title{
7 Occupy Montreal and the Politics of Horizontalism
}

\author{
Marcos Ancelovici
}

Direct democracy and non-hierarchical modes of organization - in a nutshell, horizontalism - are among the defining features of the anti-austerity protests that many countries have experienced in the last few years (Castells 2012; Cruells and Ibarra 2013; Fernández et al. 2012; Glasius and Pleyers 2013). ${ }^{1}$ Some authors even claim that these features, as embodied in the model of the assembly, prefigure "the possible infrastructure of the common" and represent a point of convergence for left-wing forces (Thorburn 2012: 256). Why do activists adopt such horizontal and participatory organizational forms rather than another? And how do they settle on a particular form of horizontalism rather than another?

This chapter addresses these questions by looking at the case of Occupy Montreal. The latter involved the occupation of Victoria Square, in the financial district of Montreal, from 15 October to 25 November 2011. Instead of assuming that the horizontalism of Occupy Montreal is simply the product of an alleged crisis of representative democracy or a spontaneous diffusion effect of the Spanish Indignados or Occupy Wall Street (which had begun a month earlier, on 17 September), this chapter argues that we need to problematize horizontalism and treat it as the uncertain and temporary outcome of a political process. Participants in Occupy Montreal permanently improvized and gradually defined the organizational form of the occupation through trial and error. Furthermore, their understanding of the assembly evolved as the occupation unfolded, to the extent that many of them ended up having mixed feelings and holding preferences different from the ones they held initially.

In order to substantiate this argument, this chapter first presents Occupy Montreal, highlighting particular events and some basic characteristics of the occupiers. Second, it briefly discusses two ways of accounting for horizontalism - the continuity hypothesis and the diffusion hypothesis - and then introduces a third hypothesis that focuses on the politics of

1 This research was supported by funding from the Social Sciences and Humanities Research Council (SSHRC) of Canada. I wish to thank Francis Dupuis-Déri for comments and suggestions on a previous version. 
horizontalism. Finally, it analyzes the case of Occupy Montreal from the standpoint of this last hypothesis and elaborates on the practical and contingent nature of horizontalism.

This chapter is partly based on ethnographic and participant observation during the entire length of the occupation of Victoria Square, in the financial district Montreal, from 15 October to 25 November 2011, and a few assemblies that followed the eviction. Although I never spent the night at the encampment, I spent between 10 and 15 hours a week at the occupation and attended many general assemblies. On 29 October 2011, I also conducted a survey on the site of the occupation with the help of 12 other interviewers, mostly graduate sociology students from McGill University (where I was teaching at the time). ${ }^{2}$ Our two-page survey questionnaire combined multiple-choice and open-ended questions. We interviewed 74 persons out of approximately 250 occupiers present that day. ${ }^{3}$ We tried to select interviewees randomly while wandering around the site but faced obvious sampling problems. Insofar as urban occupations are open and public spaces, people are free to come and go throughout the day and night. It follows that the people wandering around the site, attending general assemblies, and/or spending the night can vary continuously. Sampled interviewees could have been regularly attending general assemblies or spending the night on the site, but they may have stopped doing so right after the interview. Inversely, some participants may have joined the occupation after we conducted the survey and thereby changed its demographics. There are no clear boundaries and fixed qualities that can be used to identify the population to sample from. There is thus no way of knowing for sure whether our sample of 74 is representative of the larger population. Our sample should only be seen as a snapshot of a significant segment (about 30 per cent) of the population present on 29 October, exactly two weeks after the beginning of the occupation.

After the occupation ended, I conducted 12 semi-structured interviews between December 2011 and February 2012 in French and English with key informants who had played a central role in different dimensions of

2 We built on the method developed by Mayer, Favre, and Fillieule (1997). I wish to thank the following people for helping me design and conduct the survey:Jason Carmichael, Leslie Cheung, James Falconer, Katy Fallon, Sara Hall, Ilju Kim, Alex Mochnacki, Anahi Morales Hudon, José Ignacio Nazif Muñoz, Alessandro Olsaretti, Pablo A. Quintanilla Bedregal, Marie-France René, and Kalyani Thurairajah. Special additional thanks to Leslie Cheung for producing the Excel spreadsheet.

3 Participation/attendance varied from about 3,00o people during the first weekend (1516 October 2011) to about 75-100 in the last days preceding the eviction of 25 November 2011. 
the occupation: in the facilitation of assemblies, in the media committee, in maintenance or infrastructure operations, etc. Each interview lasted between one hour and a half and six hours and were transcribed and coded $^{4}$. I focused primarily on the occupiers' background and trajectory as well as experience and understanding of the occupation. Although a few occupiers I interviewed had a little activist background, most of them were complete beginners and experienced the occupation as a life-altering event.

\section{Introducing Occupy Montreal}

On 15 October, 2011, in response to a call to action from the Spanish Indignados, people took to the streets and occupied public squares in more than a thousand cities throughout the world. ${ }^{5}$ It was almost a month after the beginning of the occupation of Zuccotti Park next to Wall Street, and exactly five months after the occupation of the Puerta del Sol in Madrid, which initiated the mobilization of the Indignados in Spain (or $15 \mathrm{M}$, for ${ }_{15}$ May). In Montreal, activists started to plan the occupation in late September. A Facebook page that called for a brainstorming and planification assembly was created, and there were five assemblies prior to the occupation. ${ }^{6}$ The main topics addressed were initially the logistics of the camp/occupation, 7 the 'diversity of tactics' - an old issue that had been at the center of the global justice movement since the late 1990s and early 2000 - and the decision-making process of the assembly itself.

From the very beginning, people participated essentially as individuals rather than members of organizations. In this respect, the dynamic of the movement fit what Juris has called a logic of aggregation rather than one of networking:

4 I wish to thank Marc-André Cyr and Sean Waite for transcribing the interviews.

5 However, a map of these occupations indicates that the bulk of occupations took place in Western, developed countries. See http://www.theguardian.com/news/datablog/2011/oct/17/ occupy-protests-world-list-map.

6 The assemblies took place at the agora of the Université du Québec à Montréal (UQAM) in downtown Montreal and in the surrounding area (at Émilie-Gamelin Square and the café L'Escalier).

7 Throughout this chapter, I use the words 'occupation' and 'camp' interchangeably. 'Camp' refers to a 'protest camp' as defined by Feigenbaum, Frenzel, and McCurdy: "a place-based social movement strategy that involves both acts of ongoing protest and acts of social reproduction needed to sustain daily life" (2013: 12; italic in original). 
Whereas networking logics entail a praxis of communication and coordination on the part of collective actors that are already constituted - including particular organizations, networks, and coalitions (cf. Fox 2009) - logics of aggregation involve the coming together of actors qua individuals. These individuals may subsequently forge a collective subjectivity through the process of struggle, but it is a subjectivity that is under the constant pressure of disaggregation into its individual components. (2012: 266)

This feature was pervasive throughout the occupation. It fostered an inclusive dynamic that brought together people that were not part of militant organizations and were thus not mobilized through pre-existing and more institutional channels. As Juris has pointed out, the use of social media like Facebook and Twitter ${ }^{8}$ before and during the occupation was critical in this respect:

Rather than generating organizational networks, [social networking] tools primarily link and help to stitch together interpersonal networks, facilitating the mass aggregation of individuals within concrete locales through viral communication flows. In this sense, rather than mobilizing 'networks of networks', the use of Twitter and Facebook within social movements tends to generate 'crowds of individuals.' At the same time, (...) social networking sites (...) have lower barriers to access and participation, and thus penetrate wider social networks, helping to explain the broader degree of participation in the \#Occupy movements beyond the traditional activist communities involved in movements of the recent past. (ibid: 267)

Following this logic, Occupy Montreal was more diverse and inclusive than previous activist protest events but also more subject to fragmentation or dissolution. Sustainability was thus a critical challenge, even more than in other types of mobilizations and social movements.

The first weekend of the occupation was dominated by an ecstatic aura. On the first day, about 3,00o people showed up at Victoria Square ${ }^{9}$

8 In Occupy Montreal, Facebook was significantly more important than Twitter (see Table 7.1).

9 Victoria Square is located at the intersection of Beaver Hall Hill and McGill Street, across the street from the old stock exchange (Montreal no longer has a stock exchange), the headquarters of the media multinational Québecor, and the World Trade Center. It is made of two strips, one with a long, rectangular fountain and the other with many trees. It is in this latter strip that the 
to participate in a chaotic general assembly (GA), which made only two decisions that day: renaming Victoria Square as 'People's Square' (Place des peuples) and interrupting the assembly to join a demonstration that was starting from the square. The second day, fewer people showed up but the number of tents began to increase significantly while the assembly got to business and engaged in a lengthy and tortuous process of meta-deliberation (deliberating on the rules of deliberation) that lasted more than a week. During the first ten days, occupiers held a GA on a daily basis. These assemblies lasted several hours and had the effect of attracting passersby as well as consolidating the core group of participants. GAs would begin at $6 \mathrm{pm}$ so that full-time workers and employees could attend and participate in the decisions. By late October, the GA decided to meet only thrice a week: on Tuesday, Thursday, and Saturday.

It would be impossible to summarize all the events and everyday struggles that shaped the evolution of the occupation. The practical management and logistics of the camp were a central issue from the beginning, but their importance kept growing over time as occupiers had to deal with homeless people looking for food and shelter, pressure from the police and the City of Montreal, cold weather, etc. The main management issues were the food supply, sanitation, and security. During the entire occupation, there were activities and actions organized in or initiated from the camp: workshops and training sessions, protest actions in the surrounding financial district, demonstrations starting from or passing by the camp, etc. Although there was a demonstration on the very first day of the occupation and many occupiers participated in the 3 November protest against the G2o Summit in France, the most important protest event was arguably the student march on 10 November. Heralding the intense mobilization that would take place only a few months later during the so-called 'Maple Spring' (see Ancelovici and Dupuis-Déri 2014), between 15,000 and 30,000 students on strike stopped by the People's Square to celebrate the occupation and invite the crowd to join the march. The latter then ended up at neighboring McGill University, where a group of students occupied an administrative building, leading the University to eventually call in the riot police.

A few days after this demonstration, on 15 November, the Occupy Wall Street (OWS) camp in New York City was evicted, and a coordinated wave of camp evictions began throughout North America (in the United States as well as Canada). The Montreal police increased the pressure on local 
occupiers, and rumors of an imminent eviction began to circulate. On 21 November, some occupiers decided to take the lead. In the early afternoon, members of the media committee of Occupy Montreal held a press conference and announced that they were leaving the camp. The statement had not been discussed at the GA, but the media immediately announced the end of the occupation. This situation fostered even more tension and conflict in the GA. The media committee was asked to attend the GA the next day to explain its statement, and the GA decided to continue the occupation regardless of the media committee or pressure from public authorities. But on Friday 25 November at 8am, approximately 300 police carried out the eviction of the camp. A few hours later, there had been 14 arrests and the occupation was over.

As in all protest camps associated with Occupy and the Indignados, Occupy Montreal was organized around the GA and a series of working committees that functioned like horizontal affinity groups accountable to the GA. There was a facilitation committee, a media committee, a kitchen committee, a philosophy committee, a security committee, an alliance committee, and so on. Each committee was relatively autonomous, but information tended to circulate between the GA and committees rather than across committees. It follows that each committee was not necessarily aware of what other committees were doing - thereby undermining the overall coherence of the occupation and potential synergies - and that the GA was the ultimate instance of legitimate power and decisions. Nonetheless, the structure and governance of the occupation represented a genuine effort at building a non-hierarchical, horizontal, and democratic micro-society according to a prefigurative logic. ${ }^{10}$ It involved not only a particular, inclusive decision-making process but also egalitarian social relations. Hence the reference to 'horizontalism,' as opposed to simply 'direct democracy.' The other potential reference could be anarchism, but I will not use it here because it implies a radical anti-capitalist stance that was not present in the discourse of the Occupy movement. ${ }^{11}$

10 Prefiguration refers to a desire to practise and experience one's values and principles in the struggle. It implies that the means and the ends are mutually constitutive and that one cannot build an egalitarian and democratic society through hierarchical and authoritarian means. On prefiguration, see Breines (1989 [1982]), Maeckelbergh (2011), and Polletta (2002).

11 The reference to 'horizontalism' is inspired by the experience of neighborhood assemblies in Argentina (see Sitrin 2006, 2012). For a discussion of anarchism in Occupy, see Aragorn! (2012b) and Graeber (2013). 
Finally, Occupy Montreal shared some demographic characteristics (see Table 7.1 below) with other instances of Occupy in North America. ${ }^{12}$ For example, as in OWS, most participants in Occupy Montreal were male, white, and under the age of 30 . More specifically, 75.6 per cent of surveyed occupiers were male, and 58.8 per cent were under $30 .{ }^{13}$ As in OWS, there was a strong orientation toward center and center-left political parties: while in New York City 33.8 per cent of occupiers identified with the Democratic Party (Milkman et al. 2013: 16), in Montreal 39.4 per cent of occupiers identified with Québec Solidaire at the provincial level and at the federal level 29.4 per cent identified with the New Democratic Party and 11.7 per cent with the Greens. ${ }^{14}$ However, non-identification was much stronger in Montreal than in New York: while in the latter 20.6 per cent of respondents did not identify with any party, in the former this number reached 47 per cent at the federal level and 51.5 per cent at the provincial level. But the main difference between Occupy Montreal and OWS was socio-economic. In New York City, 80 per cent of occupiers had a bachelor's degree or higher and 37 per cent had an annual household income above US\$100,000 (ibid: 10). In Montreal, only 25 per cent had a bachelor's degree or higher and only 2.1 per cent had an annual personal income above $\mathrm{CAN}_{550,000}$ (66.6 per cent had an annual

12 All the data about Occupy Montreal cited here is based on the survey that my students and I conducted on 29 October $2011(\mathrm{n}=74)$. For demographic data on Occupy Wall Street (OWS) in New York City, see Milkman, Luce, and Lewis (2013). Milkman, Luce, and Lewis's data is based on a survey conducted on 1 May 2012, nearly six months after the eviction of OWS: "We surveyed a total of 729 people who took the time to attend the May 1 rally and/or march, more than half of whom were 'actively involved' in OWS. The results include a demographic profile of New York City Occupy participants and supporters, along with data on their political identities, organizational affiliations, and previous activism, and on the specific concerns that led them to support OWS. Although some participants in the march attended because of their affiliations with unions and immigrant rights groups, nearly all of survey respondents (97 per cent) responded affirmatively when asked, 'Do you consider yourself a supporter of the Occupy movement?" (Milkman et al. 2013:3). In order to make Milkman, Luce, and Lewis's data relatively comparable to mine, here I refer to the category "Actively involved respondents" of their survey rather than to "all respondents" because the latter includes outside supporters whereas my own data only looks at people on the site of the occupation.

13 The contrast between male and female activists was not as high in New York City, where male activists made up 54.8 per cent (Milkman et al. 2013: 47). As I mentioned earlier, my survey data is to be treated with caution, as it suffers from several sampling problems. However, it does give us a relative sense of the crowd present on the site of the occupation on the day of the survey insofar as we interviewed 74 people out of approximately $25^{\circ}$ (that is 30 per cent of the population). Most people surveyed did not provide information on their ethnic or racial identification. My claim that most participants were white is only based on observation during assemblies and actions throughout the occupation and I cannot provide a specific number. 14 The provincial and federal levels were treated as two distinct questions. 
Table 7.1 Demographic Characteristics of Occupy Montreal (\%)

\begin{tabular}{|c|c|c|c|c|c|}
\hline \multirow{2}{*}{$\begin{array}{l}\text { Gender } \\
(n=74)\end{array}$} & \multirow{2}{*}{$\begin{array}{l}\text { Male } \\
\text { Female }\end{array}$} & \multirow{2}{*}{$\begin{array}{l}75.6 \\
24.4\end{array}$} & \multirow{12}{*}{$\begin{array}{l}\text { Political } \\
\text { Party } \\
\text { Orientation }\end{array}$} & \multicolumn{2}{|l|}{ Provincial level $(n=66)$} \\
\hline & & & & Québec solidaire & 39.4 \\
\hline \multirow{3}{*}{$\begin{array}{l}\text { Age } \\
(n=68)\end{array}$} & $<30$ & 58.8 & & Parti québécois & 4.5 \\
\hline & $31-50$ & 27.9 & & Other & 4.5 \\
\hline & $>50$ & 13.2 & & None & 51.5 \\
\hline \multirow{4}{*}{$\begin{array}{l}\text { Language } \\
(n=74)\end{array}$} & French & 70.2 & & Federal level $(n=68)$ & \\
\hline & English & 18.9 & & New Democratic Party & 29.4 \\
\hline & Bilingual & 5.4 & & Green Party & 11.7 \\
\hline & Other & 5.4 & & Bloc québécois & 5.9 \\
\hline \multirow{7}{*}{$\begin{array}{l}\text { Educational } \\
\text { Attainment } \\
(n=68)\end{array}$} & High school or less & 36.7 & & Other & 5.9 \\
\hline & $\begin{array}{l}\text { Preparatory school } \\
\text { (cégep) }\end{array}$ & 16.2 & & None & 47 \\
\hline & Some college & 22.1 & & & \\
\hline & Bachelor's degree & 14.7 & \multirow{8}{*}{$\begin{array}{l}\text { Prior } \\
\text { Political } \\
\text { Experience } \\
(n=230)^{\mathrm{a}}\end{array}$} & & \\
\hline & & & & Signed petition & 23.5 \\
\hline & Master & 5.9 & & Voted in elections & 21.7 \\
\hline & Ph.D. & 4.4 & & $\begin{array}{l}\text { Participated in march } \\
\text { or rally }\end{array}$ & 23.5 \\
\hline \multirow{2}{*}{$\begin{array}{l}\text { Employment } \\
\text { Status } \\
(\mathrm{n}=59)\end{array}$} & Employed & 59.3 & & Participated in strike & 13.5 \\
\hline & Unemployed & 40.7 & & $\begin{array}{l}\text { Organized march or } \\
\text { rally }\end{array}$ & 9.1 \\
\hline \multirow{4}{*}{$\begin{array}{l}\text { Annual Income } \\
\text { (CAN\$) } \\
(n=48)\end{array}$} & $0-15,000$ & 66.6 & & Other & 5.2 \\
\hline & $15,001-30,000$ & 14.6 & & None & 3.4 \\
\hline & $30,001-50,000$ & 16.7 & \multirow{2}{*}{$\begin{array}{l}\text { Social } \\
\text { Media Use } \\
(n=74)\end{array}$} & Facebook & 71.6 \\
\hline & $50,001+$ & 2.1 & & Twitter & 21.6 \\
\hline
\end{tabular}

Source: Non representative survey conducted on the site of the occupation, 29 October 2011. The $n$ varies because not all respondents answered all the questions. ${ }^{a}$ The $n$ is higher than for other questions because people could check several answers at once.

income below CAN $\$ 15,000) .{ }^{15}$ Similarly, while in New York City only 8 per cent of occupiers were unemployed (ibid: 47), this number reached 40.7 per cent in Montreal. Accordingly, participants in Occupy Montreal were on average significantly less educated, less employed, and poorer than the protestors in OWS. Finally, it is worth pointing out that in Montreal, 23.5 per cent of

15 Milkman, Luce, and Lewis's study (2013) mentions household income but does not include any information about household composition and whether all adults in the household work. In contrast, my data refers to individual income and does not include any information about household income. 
surveyed occupiers had participated in a demonstration or rally, 9.1 per cent had organized one, 13.5 per cent had participated in a strike, 21.7 per cent had voted in political elections, and 23.5 per cent had signed a petition. Thus, the great majority of participants had limited or no prior experience of activism. This is another indicator of Occupy's capacity to attract people beyond pre-existing activist networks and institutional channels.

\section{Accounting for Horizontalism}

In the Occupy movement, the occupation of public squares was not merely a tactic; it was also a claim about the virtues of civic participation and a demand for more democracy. Workers occupy workplaces, students occupy universities, citizens occupy public places. ${ }^{16}$ Furthermore, the word 'occupy' was applied to a great variety of objects - Occupy the Hood, Occupy Our Homes, Occupy Theory, etc. - to refer to the desire to regain control over something through active, grassroots participation. In Europe, although the language was slightly different, similar practices and organizational forms seemed to be at play. How did activists settle on a given organizational form and set of practices rather than another? And did activists actually settle on something, or were these practices and form simply transient equilibria?

Although a systematic comparative analysis of the practice of horizontalism in different settings would be necessary to address these questions, we can nonetheless problematize horizontalism and treat it as an outcome to be explained rather than a given or spontaneous feature. Unfortunately, social movement studies do not provide many leads in this respect. As Della Porta and Rucht (2013: 2) have pointed out, "what is actually happening 'on the ground' is rarely studied - namely, what the internal and mostly unspectacular life of social movements looks like, what movement groups do in their routine meetings, what they discuss and how, and the ways in which they take decisions. (...) social movement studies have devoted little attention to democracy within movements themselves". This being said, the practice of horizontalism can be treated as the expression of a movement culture, that is, a shared set of understandings and modes of action. Put this way, it is possible to formulate two non-exclusive hypotheses that I call the continuity hypothesis and the diffusion hypothesis.

16 When they engage in street protests, workers and students also occupy public spaces. However, as soon as they step out of their workplaces and universities, they intervene also (and perhaps primarily) as citizens. 


\section{The Continuity Hypothesis}

The continuity hypothesis questions the 'newness' of movements and stresses continuity with prior waves of mobilization. As several scholars (e.g., McAdam, Tarrow, and Tilly) have noted, social movement do not come out of nowhere. They build on pre-existing social networks, organizations, and know-how generated during previous contentious episodes and sustained over time. Furthermore, the particular ways in which people act together are both constrained and enabled by the existing repertoire of collective action, that is, the historically specific set of available routines to which people turn when acting collectively (cf. Tilly 1995). These particular ways of acting together also include an organizational dimension, as people fall back on what they see as legitimate forms and models that they adapt to circumstances and to the reactions of adversaries and allies (cf. Clemens 1996).

If we follow this logic, the practice of horizontalism in the Occupy movement represents the actualization of legitimate pre-existing routines and organizational forms. Several scholars have argued that the global justice, anarchist, and other radical movements have thus shaped the Indignados and Occupy movements. For example, the anarchist collective Aragorn! (2012a, p.i) stresses the continuity with anarchism: "Anarchists have been involved in every aspect of this phase of the movement. (...) We have brought people, ideas, and methodologies that have infused the Occupy Movement with a potent energy." According to Romanos (2013), the $15 \mathrm{M}$ (that is, the Spanish Indignados) was not a spontaneous movement but built instead, through a learning process, on the discourse, structures, and work of previous mobilizations against precariousness and austerity as well as on the global justice movement (GJM). Similarly, Graeber (2013: 23), an anthropologist and anarchist activist who participated in the GJM and OWS, presents the Occupy movement as an extension of horizontal practices that had become commonplace during the GJM: "We'd had enormous success transforming activist culture itself. After the Global Justice Movement, the old days of steering committees and the like were basically over. Pretty much everyone in the activist community had come around to the idea of prefigurative politics." As Graeber acknowledges, however, these practices have to be adapted to local circumstances and can, therefore, include an idiosyncratic dimension. For example, Razsa and Kurnik (2012: 240) argue that the practices and particular organizational form of Occupy Slovenia, in Ljubljana - based not as much on the GA or consensus model as on decentralized workshops that can develop initiatives that the GA would not necessarily support - were inspired by the GJM but 
also, and more importantly, by local struggles for minority and migrant rights during the 200os.

The continuity hypothesis suggests that the horizontalism of Occupy Montreal - and that of other occupations in North America and Europe - is not really puzzling. It was actually to be expected, for it had already been practiced for many years in radical activist networks (anarchist, feminist, and others) in Quebec before the wave of occupations began. ${ }^{17}$ This perspective has a lot of traction and is a welcome note of caution for observers and commentators who see novelty in every wave of protest. Moreover, it does not close the door to innovation. As Tilly (1995) and Tarrow (1995) have emphasized, the concept of repertoire does not imply that nothing changes but rather that change takes place primarily during contentious episodes and that innovation is bounded. The continuity hypothesis can thus accommodate what was one of the most visible novelties of Occupy and the Indignados, namely the occupation of public squares. It is not that activists had never engaged in horizontal practices before; it is that they had almost never engaged in such practices in public squares. ${ }^{18}$ According to Romanos,

One of the novel aspects of the $15 \mathrm{M}$ movement was the way it placed experiments with new forms of democracy in the centre of public space. In this way, the movement brought practices of deliberative democracy previously confined to more or less limited spaces such as social forums, social movement headquarters, peace camps and social centres - out into public squares, where passers-by were invited to join in. This seems to be an important difference from the practices of previous movements and mobilizations. (2013: 211)

Therefore, one could make the claim that Occupy Montreal embodies a form of bounded innovation within the limits of a particular activist culture that made such developments relatively predictable.

17 On the anti-authoritarian and anarchist political culture in Quebec, see Sarrasin et al. (2012). On the anarchist movement in Quebec, see Bellemare-Caron et al. (2013). On the prefigurative practices of the radical feminist group Nemesis, see Kruzynski (2004).

18 It should be noted, however, that there were a few instances of horizontal occupations before the Occupy movement. In New York City, there was such an occupation in July 2011; it was called 'Bloombergville' and denounced the austerity budget of Mayor Bloomberg. According to Graeber (2013), several participants in Bloombergville participated in the first organizing meetings of Occupy Wall Street. In Canada, although there had not been occupations of public squares as such, there had been instances of camping in front of the parliament to make demands. Thanks to Francis Dupuis-Déri for bringing this last point to my attention. 
Although such an account is intuitively appealing and cogent, it faces an empirical problem. As my survey indicates (see Table 7.1), the great majority of participants in Occupy Montreal had no prior activist experience. Only 23.5 per cent had attended a march or rally, and only 13.5 per cent had organized one before the occupation. Put differently, almost 80 per cent of the occupiers had absolutely no prior activist experience. The same pattern shows up in the semi-structured interviews that I conducted with key players in the occupation. This raises the question of how exactly the pre-existing activist know-how and culture were transmitted from one wave of mobilization to the next. In this respect, Occupy Montreal was different from, say, OWS and the Spanish Indignados, where key players had been active in prior movements and a particular know-how was sustained in social centers (cf. Romanos 2013). Moreover, more experienced global justice and anarchist militants who could have infused Occupy Montreal with ideas and know-how, as Aragorn! (2012a) argues, did not play a significant role. Indeed, many simply looked down on the occupation. For example, members of the Convergence of Anti-Capitalist Struggles (CLAC) - one of the main anarchist groups of Montreal and active in the global justice movement, among others ${ }^{19}$ - attended some meetings and GAs of Occupy Montreal but were put off by the latter's relatively positive stance toward the police. Moreover, the CLAC did not seem to see the point of the occupation and believed it was an end in itself rather than part of a broader strategy. As a result, CLAC activists did not participate in Occupy Montreal. ${ }^{20}$

But even if anarchists had participated in the occupation, it is not clear that they would have supported the particular form of horizontalism that came to be in Occupy Montreal. The latter was heavily structured around the GA, and the ability of the different committees to make decisions autonomously - that is, without requiring the approval of the GA - was a constant object of endless debates. Anarchists and radicals sometimes favor a different, more decentralized and informal form of horizontalism. For example, Graeber argues that:

Consensus process only works if it is combined with a principle of radical decentralization. [...] It's always better, if possible, to make decisions in

19 The CLAC (Convergence des luttes anticapitalistes) was created in 2000 to coordinate the mobilization against the Summit of the Americas in Quebec City in April 2001 and, after a few idle years in the second half of the 2000s, re-assembled in 2010 to mobilize against the G2o in Toronto. It was still active in 2016. See http://www.clac-montreal.net/.

20 Interview with a CLAC long-time activist, 27 April 2012. 
smaller groups: working groups, affinity groups, collectives. [...] One should not feel one needs authorization from anyone, even the General Assembly (which is everyone), unless it would be in some way harmful to proceed without. [...] As a general rule of thumb: decisions should be made on the smallest scale, the lowest level, possible. Do not ask for higher approval unless there's a pressing need to. [...] what the GA is doing when it approves a working group is empowering it to act in the name of the GA. It's basically a form of delegation. [...] once the work has been divvied up, or once an existing group has been authorized to pursue some project, there comes the question of how often one needs to check back for approval. The general rule really ought to be: only when it's obvious it would be wrong to do otherwise. (2013: 227, 229, 232)

Similarly, Leach (2013:184) has pointed out that OWS had such a particularly complex structure that some activists talked about the "bureaucracies of anarchy". She notes that some social movements engaging in horizontal practices are structured differently - for example, the radical Autonomen movement in Germany:

Whatever collective decisions need to be made during actions are made by consensus, either in 'full gatherings' (Vollversammlungen [VV]) or in 'delegate councils.' As camps usually have no more than a few hundred people in them, the default form is the VV. [...] Importantly, however, very few decisions are made collectively during actions because there is less of an assumption that everyone needs to act together. Rather, each Affinity Group is free to act autonomously, as long as it does not endanger anyone else. (Ibid: 188$)^{21}$

Anarchist activists that participated in the 2011 occupation of Plaça de Catalunya in Barcelona go even further and denounce the GA as a mechanism fostering the homogenization of the occupation as well as new forms of hierarchy and domination:

21 Leach (2013: 187-88) presents the German Autonomen as "a militant, antiauthoritarian leftist movement that opposes all systems of domination (especially capitalism, fascism, and sexism) and practices what they call a 'politics of the first person,' which entails a commitment to nonhierarchical forms of organization and a rejection of the representational politics and vanguardist strategies of the traditional Marxist left. The Autonomen have been active in a broad range of leftist causes, most notably in the antinuclear, women's, squatters, antifascist, and alter-globalization movements." The Autonomen are part of the broader European autonomous movement. See Katsiaficas (2006). 
The beautiful thing about the encampment in the plaza was that it had multiple centers for creation and initiative-taking. The central assembly functioned to suppress this [...] The central assembly did not give rise to one single initiative. What it did, rather, was to grant legitimacy to initiatives worked out in the commissions; but this process must not be portrayed in positive terms. This granting of legitimacy was in fact a robbing of the legitimacy of all the decisions made in the multiple spaces throughout the plaza not incorporated into an official commission. (anonymous 2012: 24-25)

As the above examples clearly indicate, even among 'horizontalists' there is no consensus on the appropriate manner to organize and mobilize collectively. ${ }^{22}$ The mere presence of experienced radical or anarchist activists in Occupy Montreal would thus not have been enough to account for the particular form of horizontalism that emerged during the occupation of Victoria Square.

\section{The Diffusion Hypothesis}

The diffusion hypothesis sheds light on a distinct and yet potentially complementary dimension. According to Givan, Roberts, and Soule (2010: 10-12) as well as Tarrow (2011:192), there are three forms of diffusion: direct (relational, that is through social ties and networks, multiple membership in organizations, etc.), indirect (nonrelational, that is through "attribution of similarity" via global communications and the Internet), and mediated (brokered, that is via a third party).

While direct diffusion was clearly at play in the case of OWS, as Spanish activists traveled to New York City in the summer of 2011 and met with local activists (see chapter 9 in this volume), it does not really fit Occupy Montreal. Before 15 October 2011, when the Montreal occupation began, there were no direct contacts between the Indignados or OWS on the one hand, and Occupy Montreal on the other. And even after 15 October 2011, direct contacts between Occupy Montreal and occupations in other cities were minimal. Mediated diffusion does not really apply either, as no particular actor played the role of broker between Occupy Montreal and other occupations. The form of diffusion that is most relevant to accounting for the practices and organizational form of Occupy Montreal is

22 For example, Leach (2013) compares three different models of "collectivist democracy", including OWS. 
indirect diffusion. All the Occupy Montreal activists that I interviewed mentioned that they were following on the Internet what was happening in Egypt, Spain, Greece, and New York City, and were waiting and hoping for something similar to take place in Montreal. This is where the idea of occupying Victoria Square came from.

However, beyond the idea of occupying a public square, the extent to which the practices and organizational form of horizontalism were also diffused through indirect channels is not clear. Although decisions were made in assemblies from the very beginning - there were five meetings before the occupation, after which the GA became the central decision-making body - activists started to look more closely at how the New York GA was organized and functioned after the beginning of the occupation, during the first and second weeks. ${ }^{23}$ Furthermore, even though some participants had studied the experience of the Spanish and Greek Indignados, the Montreal GA rejected a proposition to build on a practical guide that the Spanish Indignados had produced on grounds that they should not implement a universal template but rather come up with a design suited to local needs and circumstances. ${ }^{24}$

Therefore, it seems that indirect diffusion may have potentially shaped the practices and organizational form of Occupy Montreal by contributing not as much to the transnational transfer of a model as to the actualization of latent 'endogenous potentialities for mobilization,' as Oikonomakis and Roos put it in chapter 9 of this volume. In this respect, the continuity and diffusion hypotheses are compatible. However, how this process of actualization took place is not clear, for, as I have pointed out above, pre-existing activist networks did not really play a role in Occupy Montreal. Claims about the effect of a crisis of representation suffer from the same problem. On the one hand, it seems plausible that this crisis may have contributed to structural conditions fostering indignation and horizontalism, as Oikonomakis and Roos argue. Although the last wave of the World Value Survey

23 Interview with Occupier 1 on 7 December 2011 and with Occupier 11 on 22 December 2011, both from the facilitation committee. In order to preserve the anonymity of activists and to avoid personalizing roles and positions, I do not mention any names. I only refer to the occupier's role in the camp and give them numbers (occupier 1, occupier 2, etc.). I also try as much as possible to omit details that could allow readers to identify them.

24 The guide was entitled 'How to cook a peaceful revolution' and was produced by Spanish rEvolution. It is available online and in several languages on the website of 'Take the Square': http://takethesquare.net/2011/07/15/how-to-cook-a-pacific-revolution/. There is also a how-to practical website centralizing different guides that were produced during occupations in several cities: http://howtocamp.takethesquare.net/. 
(2010-2014) did not include Canada, data from prior waves (1999-2004 and 2005-2009) suggests that the level of distrust toward political parties and the parliament is relatively comparable in Canada, Spain, and the United States. ${ }^{25} \mathrm{On}$ the other hand, though, low levels of trust could very well fuel a rise in authoritarian, far-right militancy. There is nothing self-evident in the preference for egalitarian, non-hierarchical organizational forms and inclusive and deliberative decision-making processes.

Hence the need to problematize horizontalism. Instead of attempting to falsify the continuity and diffusion hypotheses, I propose to posit continuity and diffusion as the cultural context in which Occupy activists defined their preferences as they faced concrete and practical challenges and engaged in problem-solving strategies and internal struggles. This perspective implies stressing the constructed and dynamic character of horizontalism and treating it as the uncertain outcome of a political process.

\section{Horizontalism as the Uncertain Outcome of a Political Process}

The influence of the local repertoire and of the mobilizations taking place abroad seems apparent in the fact that the would-be occupiers made decisions through horizontal deliberation from the very beginning. However, the specific way in which the decision-making should be structured was neither clear nor static. It was constantly being redefined as occupiers interacted with one another and with their environment and as events unfolded. This dynamic was essentially characterized by a very high level of improvization and reflected the division of labor among activists. In many respects, it fit Szolucha's depiction of horizontalism in several Occupy camps: "Democracy - as practised in many aspects of Occupy - was not an ideal form of society. It was a real democracy characterised by a degree of messiness and uncertainty that is connected to the realities of all political action" (2013: 22).

\section{Improvization and Trial-and-Error}

The occupiers were following neither a plan nor a strategy. Instead, they were trying to implement abstract principles and models and figuring out

25 Although Canada was not as affected by the financial crisis as Spain and the United States, it is reasonable to believe that the level of confidence towards parties and the parliament did not increase in the last few years. If anything, it is more likely to have decreased because of the multiplication of corruption scandals since 2012. 
on a daily basis what the construction and sustainability of a democratic and egalitarian camp required. As a member of the media committee explains:

We lacked resources to prepare the occupation. I must say, though, that we prepared everything in a couple of weeks and we were even wondering whether we would be able to spend the first night there, whether the police was going to let us camp. [...] the organizational and decisional structures as well as the logistics were not ready to welcome so many people on the first days. ${ }^{26}$

Similarly, a member of the facilitation ${ }^{27}$ committee remarks:

We were full of good intentions but we didn't really know where we were going. [...] It was a complete improvisation, yes I think improvisation was the leitmotiv of the whole story. Improvisation because, concretely, we were refusing [...] pre-established structures. [...] It allowed us to experiment but at the same time it cut us off from the experience of many people..$^{28}$

Improvization applied to all dimensions, not just the set-up and logistics of the camp. The particular way in which to run assemblies and the decisionmaking process were gradually defined and redefined through trial and error. Participants began with the Morin Code, a very formal model used to make decisions and manage assemblies in Quebec trade and student unions. ${ }^{29}$ Since very few participants had prior activist experience, the Morin Code was probably the only common frame of reference, as it is generally used to run student assemblies. It was part of the local repertoire of action. Nonetheless, they quickly abandoned it and began experimenting. According to a member of the facilitation committee:

We didn't have any clear functioning. At the $2^{\text {nd }}$ assembly [before the beginning of the occupation], we tried the Morin Code [...] but we realized that it didn't work. [...] It was too procedural and didn't fit the needs of this assembly. [...] At the $3^{\text {rd }}$ assembly [before the beginning of the

26 Interview with Occupier 3 on 16 December 2011 (conducted in French; my translation).

27 Here, "facilitation" refers to a series of techniques and responsibilities to facilitate the inclusion and equality of participants in a given assembly.

28 Interview with Occupier 1 on 7 December 2011 (conducted in French; my translation).

29 The Code Morin involves formal motions, amendment procedures, etc., and decisions are made with a majority vote. 
occupation], a team was given the mandate of working on the structure of the assembly; they came up with a formula in which there were no votes and the goal was consensus. People were expected to make propositions; if you didn't agree with proposition A, the facilitation team had to make a proposition $B$ and then we would assess the assembly's feelings, whether it was leaning toward A or B; if it leant toward neither, the proposition had to be reformulated. [...] It was complex and didn't really work because everybody wanted to talk and we were overwhelmed. [...] During the $2^{\text {nd }}$ week of the occupation, some people started to focus 200 percent on the best way to manage the assembly and turned to the signs and symbols used in New York. ${ }^{30}$

It was eventually decided that a quorum of 75 people was necessary to make binding decisions in the name of the GA. However, it turned out to be problematic because the GA would begin at $6 \mathrm{pm}$ and last several hours, which increasingly meant that by 10 or $11 \mathrm{pm}$ the quorum would not be met. The facilitation team also introduced a 'progressive' stack and a 'step-up/ step-back' principle that gave priority to minorities and people who had not talked yet. If consensus was not reached through deliberation, a vote was taken but decisions still required a go per cent majority.

\section{Varieties of Tasks and Perspectives}

Many participants disagreed over the best way to structure the GA and run the occupation. Nonetheless, as the occupation began, the conflict was not as ideologically driven as some depictions might suggest. In his account of OWS, Graeber (2013: 23-33) emphasizes the conflict between the 'verticals' (the 'Stalinists' of the Workers World Party) and the 'horizontals' (anarchists and sympathizers of the Industrial Workers of the World and the Zapatistas), with the Trotskyists of the International Socialist Organization in the middle. Insofar as experienced activists and militant organizations were marginal in Occupy Montreal, the conflict was not as ideological.

30 Interview with Occupier 1 on 7 December 2011 (conducted in French; my translation). It is worth pointing out, however, that the 'human mic' or 'people's microphone,' which requires the audience to repeat in concentric circles what the speaker is saying, started to be used on the very first day of the occupation even though the Montreal police had not forbidden megaphones like in New York. This reveals an 'attribution of similarity,' one of the mechanisms underlying the process of indirect diffusion mentioned above. However, it can also reflect the existing repertoire of action, for according to Graeber (2013: 50-51), this practice was already familiar to many California activists by the time of the Seattle anti-WTO protests in 1999. 
The varieties of preferences relative to the GA and the management of the occupation primarily reflected what tasks people were involved in. These tasks led them to focus on particular issues and problems that had to be addressed and, as a result, induced them to hold some preferences rather than others.

In order to outline a variety of perspectives and preferences, here I focus on a set of leading tasks,' that is, tasks such as articulating a vision, making tactical and strategic decisions, managing internal or external relations, etc., generally associated with leadership in social movements (cf. Earl 2007). Thinking in terms of 'leading tasks' allows us to discuss the critical role of particular individuals even when they do not identify themselves, or are not identified by others, as leaders (ibid: 1328). This is all the more relevant when studying a mobilization that claims to be horizontal and leaderless like Occupy. Three sets of leading tasks stand out: assembly facilitation (intra-politics), communication/media (extra-politics), and camp maintenance (infrastructure). ${ }^{31}$ Each set of tasks entailed different perspectives and preferences because of the particular issues and problems with which it was confronted.

In contrast to the maintenance and communication tasks, facilitation was required even before the occupation began. Moreover, insofar as there was a very high level of uncertainty as to the occupation's capacity to last more than a day, the main focus of attention was a rally that would include a GA as it had been seen in New York City and other places. People involved in facilitation tasks were the most forceful advocates of the GA, and the individuals who joined them tended to (initially) idealize assemblies. According to a participant who joined the facilitation committee during the first weekend of the occupation:

The myth of the General Assembly is... epic I think and integral to the icons of the Occupy movement. [...] assemblies of people are just iconic and inspiring. So I think there was a lot of anticipation and probably pressure on what that General Assembly was going to be because it was both a tribute to what that day had become a global movement and to recognize what had come before..$^{32}$

31 Although I lack systematic data on the gendered division of labor during the occupation, bits and fragments of information collected in interviews suggest that facilitation was primarily female, communication/media was primarily male, and maintenance was mixed.

32 Interview with Occupier 11 on 22 December 2011 (in English). 
Another participant who joined the facilitation committee explains:

I remember seeing this group of people working out the actual procedure for a facilitation and then watching the General Assembly, and I'm like 'This is so important!'. [...] I was really in love with the General Assembly. For me, it was the most important thing of the movement. It was what validated the movement, it was the central authority, and I put all my time into it. ${ }^{33}$

In contrast, the communication and maintenance tasks had other priorities. People involved in communication tasks were mainly concerned with setting up digital communication platforms. Although they may have valued horizontalism and had a say in discussions about the appropriate decision-making process prior to the occupation, as soon as the latter began they focused on practical issues related to their tasks and did not have much time left, if any, to attend the GA. ${ }^{34}$ One of the main persons involved in maintenance tasks is even more categorical. Although he had prior experience in the global justice movement - he claims that participating in the 2001 protests against the Summit of the Americas, in Quebec City, was a formative experience - and had participated in different urban mobilizations, the tasks in which he was involved meant he had no time left for anything else..$^{35}$ According to him, on the first day of the occupation,

nobody was actually doing anything. I mean, there was no work or anything going on and I'm thinking, you know, it's noon, we're planning on staying the night. There's tents set up and little else. And these two girls arrived with a tarp which they laid down and they put two baguettes on it. They said: 'Okay guys, all food donations can go here.' And I went up to these two girls and said: 'Hey, can I help?' And they're like: 'Yeah, we need to get a kitchen set up.' And so the first thing I did was to suggest moving it from there to where it eventually ended up. And basically me and these two girls and gradually a few other people joined, we went to work and worked like non-stop for the next 24 hours building that kitchen.$^{36}$

Interview with Occupier 8 on 9 February 2012 (in English).

35 However, horizontalism also includes the initiatives and efforts of small affinity groups active during the occupation. In this respect, if maintenance tasks were conducted on the basis of egalitarian and inclusive principles, they can be said to contribute to the overall horizontalism of the occupation.

36 Interview with Occupier 6 on 20 January 2012 (in English). 
As a result, he did not attend the GA for the first few weeks. But instead of seeing this as problematic, he despised what he considered to be an obvious lack of pragmatism:

I never went to a GA or any kind of political discussion until, like, my third week there. We were so busy. [...] For the first few weeks I was there, myself and the other people, we just rubbished the general assemblies. It was [...] a waste of time. I mean, they had assemblies every single day that would go on for hours and hours and hours, wasting all of these man-hours while stuff needed to get done. And, taking all these people that we could have been using for useful things that had to get done. Like, I understand we're trying to create an alternative form of democracy here, but at the same time, there's garbage that has to be picked up, you know? ${ }^{37}$

As this participant makes very clear, his focus on maintenance tasks led him to consider a particular set of issues and ignore others. It is in doing so that he articulated his preferences. The preferences that participants held before joining the occupation were gradually redefined as they got involved in specific tasks.

\section{Shifting Preferences}

The definition of preferences was a dynamic process rather than something that was determined once and for all. As the occupation unfolded, participants kept revising their preferences but in a way that was directly related to their tasks and particular involvement in the occupation. Over the weeks, while formally the GA was still the main locus of deliberation and decision-making, the occupation started to be increasingly segmented into several parallel circuits. One of the main lines of divide was between people actually sleeping in the camp, including several people involved in communication tasks, and others involved in maintenance and facilitation tasks just coming in during the day. ${ }^{38}$ The experience of these two segments became incommensurable, as the former criticized the latter for making, in the GA, binding decisions that affected the camp without actually being

37 Interview with Occupier 6 on 20 January 2012 (in English).

38 Participants spending the night at the camp enjoyed a higher status, a sort of symbolic capital, as they were seen as being more invested in the struggle and willing to sacrifice their comfort for the cause. 
aware of what was happening in the camp. What made things worse was the fact that many people who attended the GA - and thus participated in the decisions - were not involved in any tasks. This had the effect of undermining the legitimacy of the GA. ${ }^{39}$

Thus, a central participant in the media committee who spent many nights on the site of the occupation argues that the GA and the camp should have been two distinct entities:

The GA confused the assembly of the movement with the assembly of the camp. Anyone could attend the GA and participate in decisions about the management of the camp while they were not aware of what was happening, they lacked the right information to make appropriate decisions. As a result, people in the camp had to implement decisions that were made by the GA but that did not make any sense. After a while, people in the camp considered that the GA was more or less legitimate because it imposed decisions on them. ${ }^{40}$

This perspective is reminiscent of the point that Graeber makes about the necessity, from an anarchist standpoint, of making decisions in a radically decentralized manner and on the smallest possible scale. But participants involved in communication tasks were not anarchists. They came to hold this understanding as a result of their experience of the occupation. Nobody had anticipated this problem. It became apparent only after several weeks of occupation. It raises challenging questions about the boundaries of a public occupation and about the category of people who can legitimately be included in decisions. One of the core principles of horizontalism and direct democracy is that of inclusiveness: not only should there not be any form of discrimination, but any one affected by a decision should be able to participate in it. The problem here was that the GA included in the decisions many people not directly affected by them while others who were affected did not always attend the GA.

39 For example, during the last week of the occupation, there were several debates in the GA about whether or not occupiers should leave the square by themselves or wait to be forcefully evicted by the police. It was troubling that most people participating in these discussions and making decisions did not themselves spend the night at the camp and were thus not directly affected by the decision. The GA decided against leaving the square but then very few people showed up on Friday, 25 November 2011, when the police evicted the last campers.

40 Interview with Occupier 3 on 16 December 2011 (conducted in French; my translation). More or less three weeks into the occupation, the media committee imploded and henceforth two committees co-existed, one called excom and the 99\%Quebec. Occupier 3 was in 99\%Quebec. 
This gap between the camp and the GA led a group of participants involved in communication tasks to bypass the GA, call for a press conference on Monday 21 November 2011, and announce that they were leaving the camp. According to Occupier 3, who played a central role in this process, the press communiqué "had not necessarily been prepared in a democratic way, through the GA, but at the same time the GA, as it [stood], [was] not efficient. It [was] not solid enough and we [could not] grant it any legitimacy."41 Insofar as it took place while the City of Montreal was pressuring occupiers to end the occupation and not even a week after the eviction of OWS in New York City, this 'non-approved' press conference triggered intense debates within Occupy Montreal and reinforced the impression that the occupation was coming to an end.

But participants involved in communication tasks were not the only ones who came to express doubts and criticisms about the functioning of the GA. Even some participants in facilitation tasks, some of whom were the most enthusiastic at the beginning of the occupation, ended up gradually revising their preferences. They were exhausted and found the entire process both very taxing and frustrating. During the first week, they would meet daily at $1 \mathrm{pm}$ for four to five hours, then facilitate the GA at $6 \mathrm{pm}$ for another four or five hours, and, finally, hold a debriefing meeting. Throughout, they would be interrupted by people who wanted to complain about facilitation and the GA. They were constantly being attacked. ${ }^{42}$ As a member of the facilitation committee explains: "Facilitators always got a lot of flak for their work. They were underappreciated. People would think that they're letting their friends' propositions pass, which was sometimes the case, but most of the time it was not. They're just following the procedure, and a lot of people didn't like that."43 Although they did not necessarily reject the GA and horizontalism, some participants involved in facilitation tasks did come out of the occupation less enthusiastic. As one facilitator puts it: "At some point, I could no longer stand assemblies, it was just too much. [...] We're talking about an assembly of 100 people, 150 at most. [...] And we live in a world of 7 billion people. [...] That's why I increasingly think that this system is not viable." ${ }^{\text {44 }}$

However, the shift in preferences was not unidirectional, and some participants did come out of the occupation with a more positive understanding 
of direct democracy and horizontalism than they had at the beginning. This shift was the result of experience rather than theoretical discussions. This dynamic is well illustrated by an anecdote that a person involved in maintenance tasks told me. It is worth quoting at length:

I was very sceptical when they told me you needed a 9o percent vote to pass something, I was like 'There's no way that's going to work!' I sort of tolerate democracy in general, you know, like, direct democracy, I'm very sceptical about that idea. But now, I figured out how to make them work [...]. The example of the wooden habitations is the perfect example [...]. So we came [to the GA] that night [and said]: 'We got to take down the wooden habitations.' 'Boo, no!' A majority were against that idea. We spent the next 24 hours listening to people, having a lot of meetings, talking, listening, incorporating different ideas, and 24 hours after that failed vote, we brought back essentially the exact same thing, and it passed unanimously. And I figured out the trick to making this thing work is that you have to make people feel that their concerns are being heard, and that they are truly participating in the final decision. And, once you achieve that, then people will vote against their own interests for the benefit of the community. [...] As long as they're feeling like they're in that, you know? And that's when I started to realize this direct democracy thing maybe might work after all. ${ }^{45}$

With the eviction on 25 November 2011, the occupation came to an end and participants in Occupy Montreal looked for a new place to assemble. After a couple of meetings in different small venues in December 2011, the GA started to meet at the Darling Foundry, a visual arts center located a few blocks away from Victoria Square, in January 2012. But the experience was short-lived, as the beginning of the student strike in February and then what would be called the 'Maple Spring' sucked in all the activists of Montreal.

$$
* * *
$$

In this chapter, I have argued that we should not assume that direct democracy and horizontalism are obvious practices and organizational forms that activists adopt simply because they are imitating another mobilization, whether in Madrid or New York City, or because there is a crisis of representation. Similarly, the mere fact that other mobilizations 
engaged in relatively similar practices in the past does not explain much by itself unless we are able to show that particular pre-existing networks and organizations allow for the reproduction and transmission of a given know-how. Repertoires do not float freely; they need to be anchored in social carriers and interactions to generate effects.

We need thus to problematize the practices and organizational forms of mobilizations, be they horizontal or not. I contend that in the case of Occupy Montreal, although the practices and organizational form were indirectly shaped by the existing repertoire of action and by diffusion, they stemmed primarily from an open-ended political process in which activists involved in specific tasks were improvizing as they attempted to solve practical problems. This process was political insofar as it implied a struggle and it was open-ended insofar as it could have led to other practices and forms. As I have shown in the last section of this chapter, the activists' preferences were dynamic and kept evolving as interactions and events unfolded.

Finally, one may wonder whether it is really important to pay attention to the particular organizational form and practices of mobilizations. Perhaps it is enough to highlight that activists were critical of hierarchy and were trying to make decisions in egalitarian ways. However, if we stay at such a level of generality and abstraction, we are not saying much. It would be like saying that citizens vote without looking at electoral systems and electoral behavior. Furthermore, in the case of movements engaged in prefigurative politics like Occupy, the process is the demand, the means are the end, and vice versa. It follows that we need to have a precise understanding of the specific process and means used by activists in order to understand their demands and ends and thus what the movement is about.

\section{Bibliography}

Ancelovici Marcos, Dupuis-Déri Francis (eds.). 2014. Un Printemps rouge et noir: Regards croisés sur la grève étudiante de 2012. Montreal: Écosociété.

Anonymous. 2012. 'The Characteristics of the Occupation (Barcelona)', in Aragorn! (ed.). Occupy Everything: Anarchists in the Occupy Movement, 2009-2011. Berkeley: LBC Books, 22-38.

Aragorn! 2012a. 'Introduction', in Aragorn! (ed.). Occupy Everything: Anarchists in the Occupy Movement, 2009-2011. Berkeley: LBC Books, i-xi.

- (ed.). 2012b. Occupy Everything: Anarchists in the Occupy Movement, 2009-2011. Berkeley: LBC Books.

Bellemare-Caron Rémi et al. (eds.). 2013. Nous sommes ingouvernables: Les anarchistes au Québec aujourd'hui. Montreal: Lux.

Breines Wini. 1989 [1982]. Community and Organization in the New Left, 1962-1968. The Great Refusal. New Brunswick: Rutgers University Press. 
Castells Manuel. 2012. Networks of Outrage and Hope: Social Movements in the Internet Age. Malden: Polity Press.

Clemens Elizabeth S. 1996. 'Organizational form as frame: Collective identity and political strategy in the American labor movement, 1880-1920', in McAdam Doug et al. (eds.). Comparative Perspectives on Social Movements: Political Opportunities, Mobilizing Structures, and Cultural Framings. New York: Cambridge University Press, 205-226.

Cruells Marta, Ibarra Pedro (eds.). 2013. La democracia del futuro: Del ${ }_{15}$ M a la emergencia de una sociedad civil viva. Barcelona: Icaria.

Della Porta Donatella, Rucht Dieter. 2013. 'Power and democracy in social movements: an introduction', in Della Porta Donatella, Rucht D. (eds.). Meeting Democracy: Power and Deliberation in Global Justice Movements. Cambridge: Cambridge University Press, 1-22.

Earl Jennifer. 2007. 'Leading Tasks in a Leaderless Movement: The Case of Strategic Voting', American Behavioral Scientist, 50 (10): 1327-1349.

Feigenbaum Anna et al. 2013. Protest Camps. London: Zed Books.

Fernández Joseba et al. (eds.). 2012. ¡Ocupemos el mundo! Occupy the world! Barcelona, Madrid, Atenas, Túnez, El Cairo, Lisboa, Islandia, Oakland, Wall Street, Londres, Moscú, Tel Aviv... Barcelona: Icaria.

Givan Rebecca Kolins et al. 2010. 'Introduction: The Dimensions of Diffusion', in Givan R.K. et al. (eds.). The Diffusion of Social Movements: Actors, Mechanisms, and Political Effects. New York: Cambridge University Press, 1-15.

Glasius Marlies, Pleyers Geoffrey. 2013. 'The Global Moment of 2011: Democracy, Social Justice and Dignity', Development and Change, 43 (3): 547-567.

Graeber David. 2013. The Democracy Project: A History, a Crisis, a Movement. New York: Spiegel \& Grau.

Juris Jeffrey S. 2012. 'Reflections on \#Occupy Everywhere: Social media, public space, and emerging logics of aggregation', American Ethnologist, 39 (2): 259-279.

Katsiaficas Goergy. 2006 [1997]. The Subversion of Politics: European Autonomous Social Movements and the Decolonization of Everyday Life. Oakland: AK Press.

Kruzynski Anna. 2004. 'De l'Opération SalAMI à Némésis: le cheminement d'un groupe de femmes du mouvement altermondialiste québécois', Recherches féministes, 17 (2): 227-262.

Leach Darcy K. 2013. 'Culture and the Structure of Tyrannylessness', Sociological Quarterly, 54 (2): 159-228.

Maeckelbergh Marianne. 2011. 'Doing is Believing: Prefiguration as Strategic Practice in the Alterglobalization Movement', Social Movement Studies, 10 (1): 1-20.

Mayer Nonna et al. 1997. 'La fin d'une étrange lacune de la sociologie des mobilisations. Létude par sondage des manifestants: fondements théoriques et solutions techniques', Revue française de science politique, 47 (1): 3-28.

Milkman Ruth et al. 2013. 'Changing the Subject: A Bottom-Up Account of Occupy Wall Street in New York City.' New York City: The Murphy Institute, City University of New York.

Polletta Francesca. 2002. Freedom Is an Endless Meeting: Democracy in American Social Movements. Chicago, IL: University of Chicago Press.

Razsa Maple, Kurnik Andrej. 2012. 'The Occupy Movement in Žižek's hometown: Direct democracy and a politics of becoming', American Ethnologist, 39 (2): 238-258.

Romanos Eduardo. 2013. 'Collective learning processes within social movements: Some insights into the Spanish 15-M/Indignados movement', in Flesher Fominaya C., Cox L. (eds.). Understanding European Movements: New social movements, global justice struggles, and anti-austerity protest. London: Routledge, 203-219. 
Sarrasin Rachel et al. 2012. 'Radicaliser l'action collective: portrait de l'option libertaire au Québec', Lien social et Politiques (68): 141-166.

Sitrin Marina (ed.). 2006. Horizontalism: Voices of Popular Power in Argentina. Oakland: AK Press. -. Everyday Revolutions: Horizontalism and Autonomy in Argentina. New York: Zed Books.

Szolucha Anna. 2013. 'No stable ground: living real democracy in Occupy', Interface: A journal for and about social movements, 5 (2):18-38.

Tarrow Sidney. 1995. 'Cycles of Collective Action: Between Moments of Madness and the Repertoire of Collective Action,' in Traugott Mark (ed.). Repertoires and Cycles of Collective Action. Durham: Duke University Press, 89-115.

-. $2011\left[3^{\text {rd }} \mathrm{ed}\right]$. Power in Movement: Social Movements and Contentious Politics. New York: Cambridge University Press.

Thorburn Elise Danielle. 2012. 'A Common Assembly: Multitude, Assemblies, and a New Politics of the Common', Interface: a journal for and about social movements, 4 (2): 254-279.

Tilly Charles. 1995. 'Contentious Repertoires in Great Britain, 1758-1834', in Traugott M. (ed.). Repertoires and Cycles of Collective Action. Durham: Duke University Press, 15-42. 



\section{Part 3}

Complex Diffusion, from the Global Justice Movement to Indignados to Occupy 



\title{
8 Social Movements and Political Moments
}

\author{
Reflections on the Intersections of Global Justice \\ Movements \& Occupy Wall Street
}

Jackie Smith

In January 2012, activists who were part of the United States Social Forum's (USSF) National Planning Committee (NPC) ${ }^{1}$ met in Detroit, Michigan to discuss responses to the recent upsurge in anti-authoritarian and anti-austerity activism in the United States and around the world. They considered why previous work to build movements in the United States hadn't allowed them to respond more effectively to this upsurge and bring more activists into the US Social Forums. The USSF - and the larger World Social Forum (WSF) process of which it is a part - was, after all, the most important focal point for anti-capitalist organizing around the world since its emergence in 2001. It is a space and a movement that organizers have consciously built to help bring together forces seeking to unite around the slogan, "another world is possible." Why wasn't this new upsurge connecting to the process? Organizers at that Detroit meeting asked whether and how the social forums had to be adapted in order to be more effective and responsive. Yet, the conversation revealed a general ambivalence about the latest upsurge of protest (NPC 2012). I attended this meeting as a delegate from Sociologists without Borders, ${ }^{2}$ a role I have served since 2008.

1 The NPC is the coordinating body for the USSF process, made up of organizations that agree to support the work of organizing the social forums (see https://www.ussocialforum.net/about). 2 In 2012, the International Network of Scholar Activists was recognized as the NPC delegate, replacing and encompassing Sociologists Without Borders and other scholar-activists and their networks. I helped found INoSA in response to what I learned in the social forum process, recognizing that we needed a structure that could activate and engage more participation from scholars over the long term. My role has been more of an 'observant participant' than 'participant observer' as conventionally understood by researchers. I have been involved first as a member of the communications working group (for the 2010 USSF) and, following Detroit, as a co-chair of the Communications and Technology working group and as an organizer/editor of the USSF Newsletter. Between November of 2012 and May of 2014, I served on the USSF's coordination team - the executive body helping carry out decisions of the NPC. Thus, my relationship with other leaders in the USSF and therefore my understanding of the process have evolved over the years. My roles and responsibilities have deepended as I have taken responsibility for working 
According to Maureen Taylor, long-time veteran organizer from the Michigan Welfare Rights Organization, "without some level of structure, [OWS] will only wallow and burn-out both the resources and the energies of those involved. It is a 'flash in the pan' without direction" (Author field notes, January 2012; see also US Social Forum 2012). Along with others attending the meeting, she noted that, while OWS activists were responding to the same economic and political pressures that motivate the movements in the US and World Social Forums, the participants in these protests lacked a sense of history and a connection to existing movements. They had failed to generate an analysis of the global causes of inequality that could guide and sustain activism over time. And most importantly, this lack of historical and global perspective made it hard for OWS to bridge racial and class hierarchies that divide people and movements in the United States.

Despite the NPC's ambivalence about some of the manifestations of OWS, organizers in the USSF recognized the need to find ways to connect with those newly activated by worsening social conditions and the protest wave they helped fuel. Discussions within the USSF continue to treat contemporary protests as important and relevant. Indeed, how could the forums be effective at challenging global capitalism if they could not attract the energy and creativity of newly engaged activists, and help them deepen their analyses to connect their personal grievances to the capitalist world-system?3 Maureen Taylor argued that "[a] sustained, engaged social movement building process can be achieved if USSF/WSF attendees take the time to communicate with folks from the Occupy Movement" (US Social Forum 2012). Both the NPC and the World Social Forum's International Council have, in months following this gathering in Detroit, worked to include activists from the Arab Spring, the European anti-austerity movement, and the OWS movements in their deliberations. ${ }^{4}$ Also, a number of members of the NPC have continued to work locally and nationally to engage with activists in OWS, ${ }^{5}$ and OWS organizers have been invited to NPC meetings and USSF working groups.

groups, helped build the USSF's newsletter, and been elected to the leadership committee of May First/People Link, the technology activist coalition providing technology infrastructure for the Forums.

3 In their critiques, organizers referred not only to the most recent wave of OWS activists but also to earlier upsurges in 2011 to defend attacks on the labor movement in states like Wisconsin, Ohio, and Indiana (author's fieldnotes).

4 Report of the Preparatory Assembly to the World Social Forum (2012).

5 For instance, May First/People Link, a key player on the USSF NPC and in the WSFs, provides free internet hosting and support for local OWS groups. Edge Funders, which has a connection to the USSF NPC, helped bring several OWS members to the International Council meeting of the WSF in Monastir in July 2012 (http://www.edgefunders.org/). 
This outreach from more established movements is leading to some engagement by activists who have been inspired and activated through the more recent wave of anti-austerity protests in the WSF process and who are looking to sustain their activism as these street manifestations recede. Most notably, the World Social Forum in Tunis in 2013 represents a convergence of these streams of activism. As with other WSF events, the 2013 forum attracted more youthful, anarchist tendencies that sought to present a more radical/oppositional position in the space of the WSF. This tendency was reflected in the work of 'interoccupy' to mobilize an international convergence at the WSF in Tunis in 2013. Interoccupy grew out of meetings of European and Mediterranean activists who were active in the Spanish 15 May mobilizations, Occupy, and other grassroots groups and movements. Two networks, 'Agora99' and 'Firenze10+10', helped launch interoccupy discussions about organizing for the WSF in Tunisia, "recognizing this can be the right time and place to come together and share our experiences and practices". Agorag9 and the European Meeting on Debt, Rights, and Democracy organized a meeting in November 2012 in Madrid to discuss shared concerns around debt, human rights, and democracy. This meeting, in turn, grew out of a proposal made at the 'Blockupy' meeting in Frankfurt, Germany in May 2012. ${ }^{6}$

As a result of these efforts, 'Occupy the Square' took place alongside the 2013 WSF in Tunis, engaging with some elements of the Tunisian and other Arab Spring movements. ${ }^{7}$ The organizing rationale behind Inter-Occupy's effort to organize around the WSF Process was stated in their outreach call:

Tunis has become a symbolic place for the global movement, as the Arab Spring was born there. March would be a proper time to gather and exchange with all movements and networks flourished in the North African regions, in the Arab World, in Europe and all over the world. This forum could serve as a meeting place for those involved in Occupy/15M/and all horizontal assembleary social movements. [...] We can practice our methodologies, as we did in the assembly we organized in Florence during Firenze 10+10 (http://occupyfirenze99.wordpress.com/), communicate and share our new knowledge and tool kits. We can build and strengthen

6 http://99agora.net/2012/o7/euro-mediterranean-meeting-debt-rights-democracy/.

7 Tunisian activists invited the WSF to Tunisia to help them build and solidify their resistance. Many Tunisian organizers worked closely with the WSF International Council to organize the WSF meeting. Occupy the Square attracted more anarchist tendencies, many of whom were supported by international funding aimed at bringing OWS and other anti-austerity activists to the WSF. 
the links between existing networks around the Mediterranean region and globally. ${ }^{8}$

Moreover, this statement from the initial call for participation signals how activists understood the WSF process as a space or opportunity for helping generate new energy and for focusing on the issues being raised by the Indignados, OWS, and Arab Spring movements:

Do we need to Occupy World Social Forum, in order to come together at the global level, for the first time since $15 \mathrm{M}$ or Tahrir moments? Can we create new synergies that would contribute our transnational and translocal struggles to build egalitarian and genuine democracies globally? ${ }^{9}$

These observations illustrate how the activists who have been mobilized by these new protest surges are relating to pre-existing social movement actors and vice-versa. The WSF provided a focal point and a space that enabled new activists to sustain their activities. Yet, more newly engaged activists tended to take a confrontational stance in relation to the WSF that revealed some important differences and limitations in both movement streams.

Studying these connections and the factors that shape them can help us better understand how movements develop and build knowledge and networks over time. It can also show how movements adapt their analyses, organizations, and models of action in response to a changing environment. By tracing the relationships between actors in the USSF and contemporary anti-austerity movements, we can uncover the activist projects that help engage newly mobilized activists over the long term and connect them to pre-existing movements. In addition, we can identify practices in the USSF and WSF process that are most effective at attracting new energy and participation.

Today's global wave of protest has origins in the resistance to neoliberal globalization that began with anti-IMF protests in the global South in the 1980s and 1990s (see Walton and Seddon 1994). This steadily rising wave of protest helped form the global justice movement that first drew attention in the late 1990 s and remains active in the World Social Forum process and elsewhere. Since the financial crisis of 2008 , we have seen a new surge in 
this long-term expansion of resistance to global neoliberalism. ${ }^{10}$ Many in this new protest wave are young and newly politicized activists with few ties to pre-existing movements and organizations. Yet, we should consider whether and how earlier protest waves have shaped the opportunities for these newly activated individuals and groups. Have activists been able to forge connections across movement generations and build upon past experience? Through what paths are such connections being made, and what factors facilitate or obstruct cooperation?

To address these questions, I examine how activists in the World Social Forum process have sought to engage with and respond to mobilizing opportunities created by the more recent rise of anti-austerity protests. I consider how models for collaboration that have been used and developed within the WSFs shape the efforts to integrate newly mobilized activists and groups into the WSFs. Of particular interest is the USSF's specific attention to 'movement building', and how this is manifested in response to these new openings for engagement.

\section{The Global Justice Movement Meets Occupy Wall Street}

The rise of anti-austerity protests created openings that helped spread movement ideas and analyses to a broader population (cf. Staggenborg 1998). Such openings can alter the space in which a variety of oppressed groups can resist, creating the potential for a further expansion of protests, the re-articulation of movement ideas, and for the bridging of social divisions. For instance, the global justice movement's success at articulating and disseminating critical analyses of globalization helped encourage more cooperative relations between activists in the north and south. Similarly, for George Friday, US Social Forum organizer, anti-austerity protests and OWS:

helped pave the way for people who have long been ready to resist - that is, low-income people, people of color, those who have long suffered the consequences of capitalism gone wild and corporate greed. Those folks are the most vulnerable, so when they see white people enraged and mobilized despite their privilege, there is hope that it will create some more space or breathing room for these folks to escalate the struggle. (Friday 2012)

10 This conceptualization differs from that put forward in the introduction to this volume in its attempt to bring a world-historical perspective to the protests. 
The wave of protests following the 2008 financial crisis has also helped activists in different countries understand their struggles in more global terms. The financial crisis demonstrates the cross-national similarities in people's everyday experiences, and as people observe protests happening in different places simultaneously, they are likely to think differently about their situations. ${ }^{11}$ While established movements and the communities that sustain them (such as the WSF process) help articulate and incubate analyses and ideas about social change, moments like the economic crisis of 2008 help disrupt and delegitimate dominant discourses and create openings in which new publics emerge.

By thinking in terms of the intersections of movements and moments, we can better understand how the knowledge and insights of past organizing can shape the leadership and initiatives that emerge later on. In her research on autonomous groups, Flesher Fominaya has observed that the negative experiences activists confronted in their work to advance participatory and autonomous forms of politics, even when they failed,

created a shared history and a bond between activists that lasted even as they moved into other projects. They also carried the lessons of their failed experiments into new groups: much of the success of [a newer organization formed by experienced activists] rested on this shared commitment to not repeating past mistakes. (2010: 399)

Similarly, the work of Juris (2008) and Pleyers (2011) reveals how activists who participated in the late 1990 s and early 2000 s protests against the World Trade Organization and other sites of international financial and trade negotiations have shifted their energies and attention to more localized projects as a result of both lessons from past organizing experience and life changes such as marriage and parenthood. Thus, we see how knowledge from transnational organizing has diffused into local communities through activist networks. Also important in these examples are the life-course impacts on activists' strategic choices.

Spaces such as the World Social Forums provide opportunities for learning across different networks and generations of activists that might not otherwise converge. Reitan and Gibson (2012) and von Bülow (2010), for instance, show how the inter-organizational relationships developed through the WSF and through trade-related civil society forums helped break down rigid

11 This tendency of cycles of protest to be international is not new (Tarrow 1988, 1995; Markoff 1996). 
divides between policy-oriented and direct action activists and created new constellations of forces that developed alongside changing policy debates. Hadden (2011) further demonstrates how global justice networks contributed to the emergence of a more radical 'climate justice' network that challenged existing strategies in UN climate debates. Juris (2008) shows how radical anarchist networks developed over the course of early anti-neoliberal globalization protests and through participation in early World Social Forums. Autonomous activists pushed the World Social Forum towards more radical and participatory practices by, for instance, resisting the VIP room at the first WSF, opposing celebrity panels and appearances by party and government officials, and by pressing for the democratization of the forum agendas.

In light of this, we might see the rise of anti-austerity protests as WSF founding member Gustave Massiah does: ${ }^{12}$ as a "new phase in the alterglobalisation movement". He observes that:

the new movements testify to a new phase. And a new phase does not cancel out the previous ones. Each new phase extends, adds to and renews the form of previous phases. It forces them to transform. [...] the two groupings will mutate, leading to the birth of a new era of movements. [...] Older alterglobalisation movements should learn the lessons of their achievements and limitations. (2012b: 5, emphasis added)

Many participants in the most recent protest wave, and perhaps especially those in the United States, have lacked a global and systemic analysis and a commitment to long-term movement building. Thus, we see that in many places the movement quickly dissipated after its initially vibrant first few months. Nevertheless, this wave contributes to the work of other movement streams by advancing new technologies for communication and exchange that help 'redefine politics' by testing more democratic practices and helping "link the individual to the collective" (ibid.). Thus, we see in this convergence of different streams of activism a potential for the merging of ideas, experiences, perspectives, and knowledge that contribute to the continuous evolution and reinvention of the practices of contentious politics. In the following section I explore some of the differences in the logics guiding the WSF process and the anti-austerity protest wave and their implications for social movement theory. Again, I do this from the standpoint of doing observant participation in the organizing work at the national and

12 Massiah is a co-founder and has played a leading role in the French section of ATTAC, which was instrumental in helping launch the World Social Forums. 
international levels with the USSF and locally with OWS activists (see e.g. Juris and Khasnabish 2013).

\section{The Logics of Social Movement Action and the WSF Process}

The tensions seen between USSF and WSF organizers and newer mobilizations are partly a result of different practices and assumptions about activism and organizing work. Bennett and Segerberg (2012) describe these as differences in logics of activism. More established activist groups tend to emphasize a logic of collective action, while newer groups reflect a logic of connective action. The former stresses the role of more formal organizations and ideological identity formations, and the latter emphasizes the self-motivated use of digital media and the sharing of personalized content through social media networks:

In place of content that is distributed and relationships that are brokered by hierarchical organizations, social networking involves co-production and co-distribution, revealing a different economic and psychological logic: co-production and sharing based on personalized expression [...] the starting point of connective action is the self-motivated (though not necessarily self-centered) sharing of already internalized or personalized ideas, plans, images, and resources with networks of others. (Bennett and Segerberg $201275^{2-753)}$

The emphasis is thus on personal identity and autonomy, with fluid commitments to groups and a rejection of formal organizations and ideological rigidity. Figure 8.1 illustrates these logics and their implications for organizational strategies.

Reinforcing the claim about the distinctive tendencies in the newer protest upsurge versus established forms of activism, Massiah (2012a) observes that "[t]he new movements place stronger emphasis on individual liberties rather than on social justice and equality, on 'libertarian' approaches to government regulation and on spectacular direct action rather than longterm collective action". And Flesher Fominaya (2010: 382) concludes that "[o]ne of the features of contemporary autonomous politics is the weakening of personal and social identity requirements for participation". She observes, moreover, that this tendency is "not merely a 'natural' evolution, but is a result of the active application of the diversity principle within the movement itself" (ibid: 382-383, emphasis added). 
Figure 8.1 Logics of action and their organizational implications
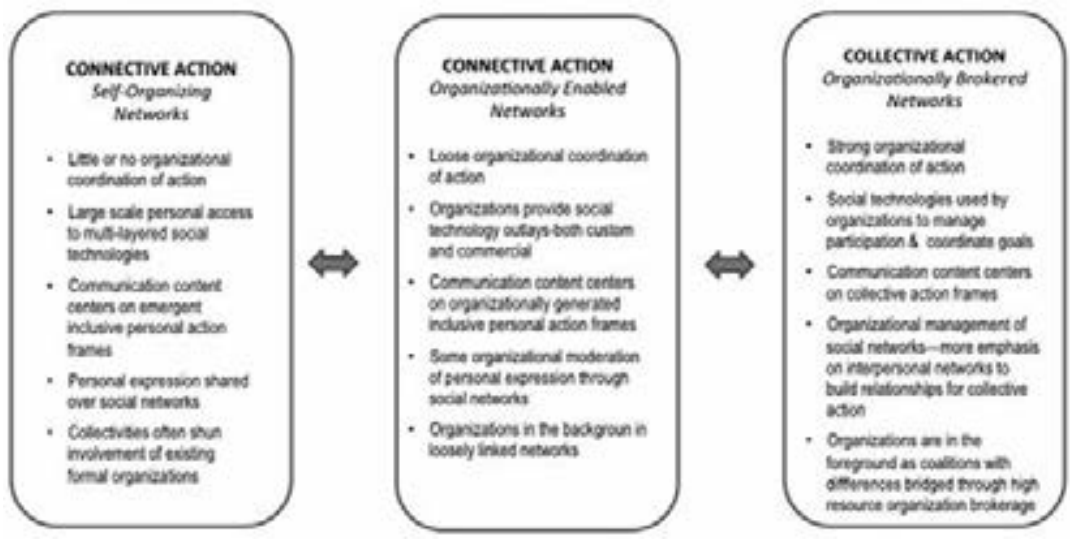

Other observers of the contemporary global justice movement have documented the presence of "flexible identities and multiple belongings" (Della Porta et al. 2006), attributing such identities to activists' commitments to inclusion and a celebration of 'unity in diversity' rather than an aversion to developing commitments to a group. Similarly, Paul Lichterman's study of political commitment in contemporary US environmental movements revealed a tendency of what he refers to as personalism, or a "cultural form that enables shared commitment to a public good and a dedication to individual autonomy and empowerment" (Lichterman 1996: 19). Personalism leads individuals to develop strong personal commitments to particular movement(s) but not to a particular organization or strategy. It is thus accompanied by a respect for the diverse choices other activists make about their participation in movements. The rise of personalism is linked to the spread of professional norms and skills accompanying wider changes in the economy and labor force. It may also reflect the increased demands that the contemporary labor market places on workers' personal time. Such demands limit people's abilities to attend regular meetings and make long-term commitments to organizations. These shared features of people's experiences where they live and in the workplace and the values that stem in part from these everyday practices are a source of unity among individuals who lack other connections. Since contemporary activism tends to be less embedded in particular religious traditions or shared identity groups, personalist forms of politics provide a basis for unity by enabling activists to "[carry] their commitments as radicalized selves to create a new community" (ibid: 192). 
Such individualized political activism is linked to broader changes in society. Bennett presents the rise of 'lifestyle politics' as a logical response to changes in the labor force, including dual-worker households and longer work hours. Busy people juggling work and activist responsibilities are less likely to commit to organizational meeting structures and more likely to engage in forms of activism that allow them greater flexibility. Wuthnow (1998) similarly attributes changes in forms of activist commitment to broader shifts in social institutions that reduce people's sense of security and stability, increase demands on their time and energies, but often leave them wanting to find ways to connect with their communities. He sees the emergence of networks as a response to these institutional and labor market changes. Similarly, López (2007) argues that the prolific growth of the Internet is a response to the alienation that is endemic to globalized capitalism.

While such personalist, individually empowered networks can enable certain kinds of mobilization and activism, the changes in people's everyday lives that result from shifts in the labor markets and broad structures of social organization make conventional forms of political mobilization less effective than they may have been in the past. More fragmented and individualized populations are "hard to reach and even harder to induce to share personally transforming collective identities" (Bennett and Segerberg 2012: 751-752). As a result,

many organizations are finding they must engage people differently: they are developing relationships to publics as affiliates rather than members, and offering them personal options in ways to engage and express themselves. This includes greater choice over contributing content, and introduces micro-organizational resources in terms of personal networks, content creation, and technology development skills. (ibid: 760 )

Reflecting these changes, organizers in the WSF process are calling for a 'social forum of a new type'. Despite its dynamism and size, the WSF has been limited in its ability to build movement power. This may be due in part to this technological and social-structural context.

Digital technology and social media alter the landscape of social movement organizing in important ways, just as they contribute to the other shifts noted above such as transformations in the workplace. Earl and Kimport's study of electronic activism (2011) concludes with a call to re-think social movement theory to reflect how technology empowers individual activists, reduces organizing costs, and alters the role of 
organizations in social movements. Reflecting these developments, there have been discussions in both the US and World Social Forums about the role of formal organizations. Whereas in the past, only organizations had been allowed to participate in the main decision-making bodies or submit proposals for workshops and panels (Sen 2003), there have been efforts to relax these requirements. Organizers acknowledge that many of those exercising important forms of leadership in the WSF process do so more as individuals than as representative of organizations - even when they can claim an organizational affiliation. ${ }^{13}$ Individual participation is certainly valued and possible in the forums, and individuals participate directly in working groups that have important roles in shaping how the forums develop. As Juris's work shows, activists working from personalist orientations and from decentralized network-based structures rather than formally organized groups have been able to have important influences in the WSF process, often through collective efforts to challenge or "contaminate" these spaces (Juris 2008: 258; see also Juris 2005).

Juris's work lends insights into how these overlapping and competing logics are manifested in the work of the social forums and perhaps other contemporary movements. He develops the idea that elements of the earlier global justice movement incorporated a 'logic of networking' that is clearly a key force driving the WSF process. This logic of networking might be seen as an intermediary between Bennett and Segerberg's logic of collective action and their logic of connective action:

[N]etworking logics specifically entail an embedded and embodied set of social and cultural dispositions that orient actors toward 1) the building of horizontal ties and connections among diverse autonomous elements, 2) the free and open circulation of information, 3) collaboration through decentralized coordination and consensus-based decision making, and 4) self-directed networking. (Juris 2008:11)

The World Social Forums have been important sites where activists could come together to "perform their networks, create affective solidarity, and communicate oppositional messages" (ibid: 238). The movement rather than the government-centered logic of the forums helps them contribute more to the work of building the networks than other protest sites such as anti-WTO

13 USSF National Planning Committee Accountability and Coordination Team conference call held on 6 January 2012. 
or anti-G8 protests. ${ }^{14}$ Their transnational character, moreover, has allowed groups to test forms of activism developed in national and local spaces on a wider scale while articulating and strengthening broader identities (global, regional, etc.). Activists in the forum have also been developing uses of technology that expand participation in forum activities from outside the forums' host cities. According to Juris (ibid: 262-263), "forum events are critical sites for technological and organizational experimentation, while forum architectures incorporate a horizontal networking logic within their organizational designs expressed through the discourse and practice of open space".

This networking logic that predominated in the earlier wave of global justice activism has, according to Juris, been overshadowed by new forms of engagement in the most recent anti-austerity uprisings. The latter is characterized by a "logic of aggregation" that "continued to exist alongside rather than entirely displacing logics of networking” (Juris 2012: 260-261). Consistent with Bennett and Segerberg's notion of the logic of connective action and the above discussion of how this connects with larger social structures and everyday practices, the logic of aggregation:

is an alternative cultural framework that is shaped by our interactions with social media and generates particular patterns of social and political interaction that involve the viral flow of information and subsequent aggregations of large numbers of individuals in concrete physical spaces (ibid: 266).

Juris's comparison of these two logics is instructive for our understandings of contemporary efforts to mobilize and coordinate large groups. He notes that:

Whereas networking logics entail a praxis of communication and coordination on the part of collective actors that are already constituted - including particular organizations, networks, and coalitions [...] - logics of aggregation involve the coming together of actors qua individuals. These individuals may subsequently forge a collective subjectivity through the process of struggle, but it is a subjectivity that is under the constant pressure of disaggregation into its individual components - hence, the

14 During confrontational protests at inter-governmental meetings, activists organized spaces similar to the WFs. However, such sites were often framed around inter-governmental meetings rather than movement-building. 
importance of interaction and community building within physical spaces. Whereas networks are also given to fragmentation, the collective actors that compose them are more lasting (ibid: 266 , emphasis added).

In addition to the logics of connective and collective action outlined above, Bennett and Segerberg's work also identifies the presence of this third, network logic of organizing, subsuming it within the logic of connective action. They note (see Figure 8.1) that the traditional logic of collective action stresses the role of formal organizations in coordinating and facilitating action, generating "organizationally brokered networks". The logic of connectivity governs two other ideal types of organizing, which they see as including both the self-organizing networks of autonomous activists who often reject formal organization and a hybrid form of "organizationally enabled networks", where formal organizations play key roles in supporting network activity but remain in the background.

Referring again to Figure 8.1, the World Social Forum process most clearly reflects "organizationally enabled networks", since it helps create spaces for diverse groups and individuals to converge over different time points and develop network ties (see Byrd and Jasny 2010). By bringing organizations and activists together to construct and participate in social forums, the WSF process and the organizations helping sustain it provide critical resources and spaces that facilitate networking while backgrounding the organizational work typical of the collective action's logic of organizationally brokered networks. ${ }^{15}$ At the same time, participants in the process may emphasize any one or a combination of these three tendencies. Thus, it is important to keep in mind that these ideal types are, in practice, quite fluid, and different groups and individuals can manifest multiple tendencies or stress one or another at different times.

Interestingly, a look at very recent discussions in the US and World Social Forums suggests that activists are uncomfortable with the limits of the logic of connective action and more personalized action frames and commitments, even as they resist forming a unified platform or voice within the WSF. Ongoing discussions seem to point to a recognition of a need to

15 Such backgrounding can in fact be problematic, as social forum participants may tend to either criticize (sometimes unfairly) financial and other decisions taken by organizers, and take for granted the time-consuming organizing work done by volunteers. It also can make it hard for newcomers to get involved, which can lead to burnout among those most central to the leadership work. Both USSFs ended with many groups stepping back from the process due to burnout (author's fieldnotes). 
adopt practices that better support concerted if not collective action. ${ }^{16}$ The crisis has made it more urgent that those coming together around a critique of capitalism find a way to have more influence on global transformation.

The WSF's inherent logic of open space and the ideology of horizontality and autonomous action that permeates these spaces mitigates against a predominance of conventional "organizationally brokered networks". But because all of these logics are in play in the open spaces of the WSF, we see the tensions among them. For instance, the USSF National Planning Committee sees a need to play a strong organizational role in defining NPC membership in order to avoid reproducing prevailing hierarchies, and it currently is working to provide greater central coordination of the content of the USSF program in order to ensure that the forums better advance movement-building goals. However, this goal is in tension with the radical democratic premises of the movements themselves and may complicate efforts to create openings for new and historically oppressed groups to actually emerge and help lead the process. On the WSF's International Council, there is a recognition of the need to provide greater space for the development of collective action within the forums, in addition to calls for greater transparency and participation. This suggests a move towards more elaborated organizational structures, but how this will unfold within the forum's culture of radical democracy and opposition to hierarchy is uncertain.

In light of this theorizing about the logics orienting different streams of activism, it is instructive to examine experiences in the US Social Forum and in a local site of OWS activism to explore the possibilities for bridging different modes of thought and action.

\section{Logics and Tensions in Contemporary WSF and OWS Activism}

In both the USSF process and in the WSF International Council, there have been recent moves to formally recognize individuals as participants on decision-making bodies (author's field notes; Whitaker 2012). These developments are a response to the actual experiences of organizers working within the WSF framework who have recognized the need to acknowledge and create space for individual leadership, as well as a result of WSF activists' reflections on the similarities and differences between the new upsurge in

16 USSF organizers speak of the third US Social Forum as moving "from convergence to cohesion" (author's fieldnotes). 
protest and the practices in the Social Forums. They reflect a recognition of the changing nature of individual activism and its relationship to formal organizations. They also present a challenge for activists seeking to ensure that open spaces do not privilege particular groups in ways that reproduce race, class, gender, or other oppressions. The discussions and debates within the WSF process nevertheless reflect the ways this process draws activists' attention to the operation of power within movements (see e.g. Teivainen 2007). Such attention has been absent in most (though certainly not all) spaces of OWS activism (Pickerill and Krinsky 2012; Whitaker 2012).

The question of the role of individuals has emerged in the context of the US Social Forum's work to expand and revitalize the National Planning Committee during the fall of 2012, as activists grappled with the question of how to better engage the new wave of protests. These conversations have helped organizers confront the reality that many of the organizational 'representatives' on the NPC are really committed individuals working as liaisons between particular organizations and the USSF process, in addition to their other organizational work. In addition, some individuals who played important leadership roles on the NPC but who have left the organization they were representing were not able to find an obvious way to sustain their activism in the USSF. Active participants in local organizing committees who became deeply involved in the national organizing work of the NPC thus found it hard to fit within the existing organizationally defined membership structure of the NPC. At the same time as passionate and experienced leaders were unclear about how to remain involved in NPC work, the NPC has struggled with a need for more committed participants to carry the workload over the long term. A rather small number of core leaders have been critical to helping sustain the process. Recognizing this, organizers in both the US and World Social Forums are calling for a "social forum of a new type" and moving to formally define new categories of membership to include more space for individual activists. ${ }^{17}$

The networking logic has helped the USSF mobilize people with established organizational and movement/activist identities. However, experience in the forums has shown that prevailing organizational logics and demands often prevent organizations from maintaining long-term commitments to and support for the social forum in between forum meetings. Individual activists, however, have demonstrated sustained commitments to the work of coalition and movement-building over the WSF's more than

17 Notes from NPC meeting in Chicago held on 9-11 November 2012. Discussion of this item was on Sunday, 11 November. 
ten year history. Despite a lack of a strong organizational base of support, they have nevertheless been able to channel important resources and skills into the WSF process and to help build and sustain a network of activistorganizers with varying levels of organizational support. It is this somewhat fluid network of organizers and organizations that has helped sustain the WSF process and deepen understandings of its place in contemporary social movement work. The work of organizing social forums, in turn, has helped reinforce the unity and collective identities of participants in the process.

In the WSF and USSF, then, a logic of networking has drawn together a variety of individuals and organizations with varying degrees of centralization and formalization. Although individuals lack formal decision-making authority - that is reserved for organizations - the lived experience of the forums indicated that individual leadership has been key to the development of the WSFs, and the working group structure allows individuals to raise proposals and launch initiatives. Individuals have been able to be involved in the process as attendees of WSFs, working group participants, and as participants or organizers of social forums at local, national and regional scales. It is thus noteworthy that concurrent discussions have emerged in the USSF and in the International Council about how to integrate individual participants in a more formal way, and that this discussion is happening in the midst of the new wave of anti-austerity protests. ${ }^{18}$ The explicit 'process' that embeds the WSFs provides an ongoing framework wherein activists come together repeatedly over time and across space. Sequential iterations of forums have allowed activists to critique shortcomings of past forums, compare experiences across place and time, and articulate new practices and principles to remedy exclusions and omissions. Through this reflexive and dialogic process, participants develop a collective identity from these diverse entities and deepen commitments to the social forums and the people and movements that comprise them.

\section{Occupy Pittsburgh and the Logic of Aggregation}

In contrast to the social forum's logic of networking, the logic of aggregation or connectivity that is more characteristic of the OWS and anti-austerity protests starts with individual participants whose main motivation is communicating and engaging personal action frames. But in many places this action has been rather short-lived, even in locations with histories of labor 
and progressive activism. The temporary and geographically defined spaces in which these protests have emerged have complicated efforts to expand conversations across different social groups and locales.

Occupy Pittsburgh's camp was situated in the middle of downtown Pittsburgh, surrounded by high-rise buildings owned by the likes of BNY Mellon, a financial services company. The camp attracted many youth and older unemployed people, Iraq war veterans, young people with significant student debt, and residents from other parts of the state and country. Although the city has several universities, relatively small numbers of students were active. The camp was supported by strong local networks of activists, including both labor unions and various progressive groups which provided significant financial and legal support. Pittsburgh occupiers held general assemblies during the encampment and even for a short period after the camp disbanded, but participation was mainly by activists who were part of the camp. Although some non-campers attended the general assemblies, many grew frustrated with these and either focused on working group activities or left the movement. ${ }^{19}$ The camp lasted for nearly six weeks before it was closed by the police. During the encampment, activists staged regular protests at downtown corporate headquarters or at the offices of public officials. Many of these protests were led by activists tied to local trade unions and linked to ongoing campaigns. In addition, teach-ins and opportunities for political education and dialogue, including a monthly 'Occupy Your Mind' series, helped sustain participation by a diverse range of participants and nurtured connections among activists. Early in 2012, Pennsylvania's governor helped revive activists' energy and momentum by threatening major cuts to public transit budgets, thereby providing a focal point for Occupy Pittsburgh through the winter and spring. But by June of 2012, most participants had faded away, and those remaining grew frustrated with the group's inability to generate any effective structure to coordinate Occupy Pittsburgh's activities and expand its outreach to diverse residents of the city (Smith and Glidden 2012).

The operation of the logic of aggregation/connective action in Occupy Pittsburgh complicated efforts to build a cohesive organizing framework. As was also seen in Desbos and Royall's chapter in this volume, activists

19 I participated in Occupy Pittsburgh as a (non-camping) co-convener ('bottom-liner') of the outreach working group for its entire existence, from October 2011 through October 2012. I attended several general assemblies and other meetings of working-group leaders. I also worked to plan events that involved multiple working groups, including a rally and march for International Human Rights Day (10 December 2011), which was the first and only major Occupy Pittsburgh action in a gentrifying, primarily black neighborhood. 
who had participated in the camp and who remained active over time resisted the idea that people who were not staying at the camp could be full participants in the movement. Yet, the location of the camp, the physical and time demands associated with camping, and the operation of race, class, age, and gender-based tensions in the camps meant that many people could not participate in this way. Nevertheless, many people joined working groups and participated in Occupy Pittsburgh demonstrations and other events. Regardless of how active they were, many were still unsure of whether they could claim to be 'Occupiers' (author's field notes). This exclusionary view of what constituted membership persisted even after the camp was disbanded, preventing the renewal of activism and energy and further demobilizing activists. Dysfunctions in the camp - such as inter-personal conflicts and disagreements over safety and drug use - as well as a lack of clarity and unity around goals contributed to the decline of participation in Occupy Pittsburgh activities.

General assemblies (both in Pittsburgh and elsewhere) proved incapable of providing space for coordination and cooperation among working groups ${ }^{20}$ and efforts to create a more formal process for such coordination failed, mainly due to attrition (author's field notes). And while social media were helpful for turning out activists and providing an easy way for OWS activists to establish broad communication networks, as with the general assemblies, the absence of a process for ensuring mutually respectful and equitable participation and for holding individual participants accountable to shared norms led many to abandon the movement in disgust. Moreover, many of the active participants in the social media sites were not involved in the working groups or public activities of Occupy Pittsburgh, creating a disconnect between real-time practices and online discourses (author's field notes). Beyond Pittsburgh, the limitations of the anti-organizational logic of connective action behind the OWS protests is evident in the difficulties national USSF leaders had in even identifying individual OWS activists whom they could invite to movement-building strategy meetings. ${ }^{21}$ Desbos and Royall point to similar organizational challenges in their analysis.

The experience of both the USSF process and OWS shows that collective movement identity is not a prerequisite for mass mobilization in an age

20 Their timing and the absence of pre-announced agendas and end-times made it difficult for those with regular work schedules to attend. As a middle-aged woman and a newcomer to Pittsburgh, I also found the sessions I attended to be uninviting if not hostile (see also Anonymous, 2012).

21 Notes from NPC planning call held in October 2012. 
where social media and other forms of communication technology abound, and where economic globalization and crisis have generated greater commonality in people's experiences of capitalist exploitation and marginalization. However, the work of developing individual activists' commitment to a collective political project remains important to sustaining large-scale action over time. The physical spaces in which the contemporary antiausterity mobilizations have taken place have enabled participants to have inspiring but brief experiences of community and radical democracy. But the socially and geographically situated confrontational and temporary nature of these spaces has limited the ability of activists to sustain their engagement over the long term. It has also inhibited a diversity of social groups participating in these protests. On the other hand, the WSF process has been able to articulate a process that has at least created a structure within which activists can work to build unity among diverse movements and identity groups. However, it continues to struggle to sustain a sense of community, mutual solidarity, and long-term commitment that is essential to overcome the constant pressure - created by the logic of capitalism it confronts - "of disaggregation into its individual components" (Juris 2012: 266).

$* * *$

Movements for global economic and ecological justice are seeking to engage opportunities created by the political moment of deepening crisis and popular uprising. It is useful to know what accomplishments and strengths established movements can bring to the new or re-engaged activists who have emerged in the recent wave of anti-austerity protests. However, it is also important to note how the logics and modes of action characteristic of earlier struggles might be limited for engaging activists who are part of a culture that emphasizes logics of connectivity and digital communications.

The global justice movement and World Social Forums can inform an emancipatory project that connects activists and groups across different generations and logics of political action. First, the global justice movement's work in mobilizing resistance to economic globalization can inform a deeper analysis among contemporary activists that connects local grievances with global structures and institutions. Second, global justice activists have long been articulating and practicing alternatives to capitalism, and a good deal of space in the WSFs is devoted to sharing experiences and supporting these alternatives. The opportunities to experience these alternatives helped motivate and inspire many OWS and other anti-austerity 
activists, but the context meant that these were often short-lived. Without connections to community groups or other established sources of support, the projects could not be sustained once the encampments ended. In the social forums, such foundations are intact. Third, the WSF process has stressed the importance of long-range work of movement-building, which was missing at least in the early waves of OWS and anti-austerity protests (see Smith 2012). However, the more recent efforts of USSF organizers to engage with some of the enduring OWS networks, and the participation of OWS and anti-austerity activist networks in the 2013 WSF in Tunis, show how the form and process of the WSF can help give this new wave of activists a focal point that can sustain their collective energies and visions.

This look at the ongoing work of activists in the US and WSF process to respond to the recent surge of anti-austerity protests suggests that the networking logic that has characterized the global justice movement, articulated through the concretized practices developed in the WSF process, may be important for connecting the knowledge and experience of past movement with the new energy, cultures, and technologies reflected in contemporary protests. One key factor that must be resolved, however, is the integration of individual activists into a long term movement-building process. This will require the development of shared identities and commitments that, in turn, will need to be developed from the integration of the diverse experiences and values of participants rather than from some existing model. More activists are recognizing the need to move beyond familiar templates of action and modes of commitment as they articulate a need for "social forums of a new type". Such work to develop new organizing and identity forms is cultural work, and it seems that the cultural challenge posed by OWS and other recent protests was most appealing to a larger, non-activist public. While this recognition of the importance of culture permeates most movements of the past and indeed has always been important in the WSFs, the struggle to make cultural work more central to social movements remains.

We might revisit the puzzle of the disconnect in the diverse streams of activism between the logics of collective and connective action, including how larger structural changes in society have shaped these logics. To survive and succeed, movements must mobilize new generations of activists and unite them in common struggles. In light of the relationships between collective, organizational actors and individuals outlined in the figure reproduced from Bennett and Segerberg, we might ask whether there is a need for a self-conscious attempt to develop more organizationally brokered networks that can translate between the logics of connective and collective action 
and help link global justice movements with the generation of activists more accustomed to using digital technology and online communications. The mutual engagement and learning that is possible at the intersections of movements and moments can lead to innovative practices that will radically transform political activism and the societies that shape it. In any case, it is clear that an appreciation of the different organizational and cultural logics shaping World Social Forum and anti-austerity activism can help address some of the tensions that have inhibited greater convergence among these parallel emancipatory initiatives.

\section{Bibliography}

Anonymous. 2012. 'Occupy - The End of the Affair', Social Movement Studies, 11 (3-4): 441-445.

Bennett W. Lance, Segerberg Alexandra. 2012. 'The Logic of Connective Action: Digital Media and the Personalization of Contentious Politics', Information, Communication \& Society, 15: 739-768.

Byrd C. Scott, Jasny Lorien. 2010. 'Transnational Movement Innovation and Collaboration: An Analysis of World Social Forum Networks', Social Movement Studies, 9 (4): 355-372.

Della Porta Donatella et al. 20o6. Globalization from Below: Transnational Activists and Protest Networks. Minneapolis: University of Minnesota Press.

Earl Jennifer, Kimport Katrina. 2011. Digitally Enabled Social Change: Activism in the Internet Age. Boston: MIT Press.

Flesher Fomiyana Cristina. 2010. 'Creating Cohesion from Diversity: The Challenge of Collective Identity Formation in the Global Justice Movement', Sociological Inquiry, 80: 377-404.

Friday George. 2012. 'Occupy Wall Street and the U.S. Social Forum Movement: Local and National Perspectives', in USSF Updates. Retrieved 6 January 2013 from http://www.ussocialforum.net/node/372.

Hadden Jennifer. 2011. 'Pathways to Participation in Transnational Politics at the Copenhagen Climate Summit', International Studies Association Annual Conference, Montreal.

Juris Jeffrey S. 2005. 'Social Forums and their Margins: Networking Logics and the Cultural Politics of Autonomous Space', Ephemera, 5: 253-272.

- 2008. 'Spaces of Intentionality: Race, Class and Horizontality at the United States Social Forum', Mobilization, 13: 353-372.

-. 2012. 'Reflections on \#Occupy Everywhere: Social Media, Public Space, and Emerging Logics of Aggregation', American Ethnologist, 39: 259-279.

Juris, Jeffrey S., Khasnabish Alex (eds.). 2013. Insurgent Encounters: Transnational Activism, Ethnography, and the Political. Durham: Duke University Press.

Lichterman Paul. 1996. The Search for Political Community: American Activists Reinventing Commitment. New York: Cambridge University Press.

López Alfredo. 2007. 'The Organic Internet', in López Alfredo et al. (eds.), The Organic Internet: Organizing History's Largest Social Movement. New York: May First/People Link: 7-41. Retrieved 6 January 2013 from https://mayfirst.org/sites/default/files/organicinternet.1.5.pdf.

Markoff John. 1996. Waves of Democracy: Social Movements and Political Change. Thousand Oaks: Pine Forge Press. 
Massiah Gustave. 2012a. 'The Future of the World Social Forum International Council'. Retrieved 4 January 2013 from http://www.ritimo.org/article4568.html.

- 2012b. 'Reflections on the Current Social Forums Process', WSF International Council, Dhaka, $23^{\text {rd }}$ November 2011. Retrieved 4 January 2013 from http:/www.cadtm.org/ Reflections-on-the-current-social.

NPC (US Social Forum National Planning Committee). 2012. 'Meeting notes 6-8 January'. Retrieved 4 January 2013 from http://wiki.ussocialforum.net/wiki/ Jan_6-8_NPC_Planning_Meeting_Notes.

Pickerill Jenny, Krinsky John (eds.). 2012. 'Special Issue: Occupy!', Social Movement Studies, 11 (3-4).

Pleyers Geoffrey. 2011. Alter-Globalization: Becoming Actors in the Global Age. Malden: Polity Press.

Preparatory Assembly to the World Social Forum. 2012. 'Another Tunisia is possible, in another Maghreb and another world', World Social Forum, Monastir. Retrieved 4 January 2013 from http://ffm-online.org/wp-content/uploads/2012/o7/sozforumı.jpg.

Reitan Ruth, Gibson Shannon. 2012. 'Climate Change or Social Change? Environmental and Leftist Praxis and Participatory Action Research', Globalizations, 9: 395-410.

Sen Jai. 2003. 'Tale of Two Charters', in Sen J. et al. (eds.), Challenging Empires: the World Social Forum. Waterman: Third World Institute. Available in Pdf format at www.choike.org.

Smith Jackie. 2012. 'Connecting Social Movements and Political Moments: Bringing Movement Building Tools from Global Justice to Occupy Wall Street Activism', Interface, 4: 369-382. Retrieved 4 January 2013 from http://www.interfacejournal.net/wordpress/wp-content/ uploads/2012/11/Interface-4-2-Smith.pdf.

Smith Jackie, Glidden Bob. 2012. 'Occupy Pittsburgh and the Challenges of Participatory Democracy', Social Movement Studies, 11 (3-4): 288-294.

Staggenborg Suzanne. 1998. 'Social Movement Communities and Cycles of Protest: The Emergence and Maintenance of a Local Women's Movement', Social Problems, 45: 180-204.

Tarrow Sidney. 1995. 'Cycles of Collective Action: Between Moments of Madness and the Repertoire of Contention', in Traugott M. (ed.), Repertoires and Cycles of Collective Action. Durham: Duke University Press, 89-116.

- 1988. 'National Politics and Collective Action', Annual Review of Sociology, 14: 421-440.

Teivainen Teivo. 2007. 'The Political and its Absence in the World Social Forum', Development Dialogue, 49:69-81.

US Social Forum. 2012. 'Interviews with Maureen Taylor, Michigan Welfare Rights and George Friday, Independent Progressive Politics Network', in USSF Updates, https://www.ussocialforum.net/civicrm/mailing/view/?id=87\& reset=1.

von Bülow Marisa. 2010. Building Transnational Networks: Civil Society and the Politics of Trade in the Americas. New York: Cambridge University Press.

Walton John, Seddon David. 1994. Free Markets and Food Riots: The Politics of Global Adjustment. Cambridge: Blackwell.

Whitaker Chico. 2012. 'World Social Forum Co-founder Chico Whitaker Offers an International Perspective on the Occupy Wall Street Movement', USSF Updates: Newsletter of the U.S. Social Forum. Retrieved 4 January 2013 from http://www.ussocialforum.net/node/373.

Wuthnow Robert. 1998. Loose Connections:Joining Together in America's Fragmented Communities. Cambridge: Harvard University Press. 


\title{
$9 \quad$ A Global Movement for Real Democracy?
}

\author{
The Resonance of Anti-Austerity Protest from Spain and \\ Greece to Occupy Wall Street
}

Leonidas Oikonomakis and Jérôme E. Roos

How do instances of popular protest spread across borders?' This question, which has eluded social scientists for decades, appears to have become more salient than ever in the wake of the mass protests that rocked the world in the wake of the Arab Spring in early 2011. In this chapter, we look at the diffusion of anti-austerity protests from Spain to Greece to the United States, focusing in particular on the claims and organizational forms behind these mobilizations. We note that, despite clear local varieties between them, the $15 \mathrm{M}$ movement in Spain, the Movement of the Squares in Greece, and the Occupy movement in the United States have a number of basic elements in common, most notably their critique of representation, their insistence on autonomy from political parties and the state, and their commitment to a prefigurative politics based on horizontality, direct democracy, and self-organization.

So how did this critique of representation and these alternative organizational models spread so rapidly across such widely divergent and geographically distant contexts? In approaching questions like these, social movement scholars have historically drawn on the concept of diffusion. In this chapter, we problematize some of the core assumptions behind classical diffusion theory and argue that its conceptual framework may be too linear to account for the local and transnational dimensions behind these protests. Instead of posing a clear-cut distinction between a 'transmitter' movement and an 'adopter' movement, we identify multiple sources of inspiration that simultaneously fed into each particular mobilization. We argue that - much more than simply mimicking the claims and organizational

1 The authors would like to thank John Holloway, Donatella Della Porta, Alice Mattoni, Gaston Gordillo, Eduardo Romanos, and the editors of this volume for their comments on an earlier draft. Any remaining errors or omissions are our own. This chapter develops the same argument as in a previous publication (Roos and Oikonomakis 2014) from a global and more theoretical perspective, emphasizing the commonalities between the various national instantiations of what we call the Real Democracy Movement. 
models of movements elsewhere - each of the aforementioned mobilizations drew upon extensive local movement experience and pre-existing activist networks to develop its own autonomous and horizontal forms of self-organization. Rather than mindlessly copying models from elsewhere, activists drew inspiration from other movements to activate latent potentialities for mobilization back home. We refer to this process as a pattern of resonance.

Finally, we hypothesize that the claims and tactics of the movements resonated due to the shared background against which they occurred: the dramatic deepening of a 'crisis of representation' in the wake of the 2008 financial meltdown and the consequent First World debt crisis. We also note that this crisis of representation - expressed in a dramatic fall of public trust in political representatives and democratic institutions - has been particularly deep in Spain and Greece, while it was also very pronounced in the United States. For our research, we draw on extensive participant observation in the occupations of Puerta del Sol in Madrid and Syntagma Square in Greece, as well as several return trips to both Greece and Spain for the shooting of two documentaries. We also rely on dozens of informal conversations held with fellow activists in both countries; independent research for the activist blog ROAR Magazine, of which we are the editors; and participation in Take the Square, the international commission of $15 \mathrm{M}$ in Spain, of which one of us was an organizer. ${ }^{2}$ Through Take the Square, we were actively involved in the transnational coordination of two days of global action (17 September 2011, the day Occupy Wall Street began, and 15 October 2011, when protests took place in over 1,00o cities in 80 countries on all inhabited continents). ${ }^{3}$

This chapter is divided into four parts: the first briefly discusses the theory of diffusion and introduces the concept of resonance; the second deals with the occupation of Puerta del Sol in Madrid; the third looks at the occupation of Syntagma Square in Athens; and the fourth deals with the occupation of Wall Street in New York. In the conclusion we briefly

2 Oikonomakis was present for most of the duration of the occupation of Syntagma Square; Roos joined for two weeks in late June and early July and also spent two weeks in Madrid in July 2011. Both authors returned to Athens several times, including for the shooting of a documentary on the occupation of Syntagma Square in March 2012 (Utopia on the Horizon, 2012). Roos returned to Madrid on five occasions between 2011 and 2013 for protest-related activities and the shooting of an (unreleased) documentary on the $15 \mathrm{M}$ movement.

3 For the numbers, see for instance the following report in The Guardian on 14 November, 'Occupy protests arounds the world: full list visualised'. Retrieved 1 May 2014 from http://www. theguardian.com/news/datablog/2011/oct/17/occupy-protests-world-list-map. 
discuss our findings and propose that the mobilizations in Greece, Spain, and the United States were about more than just austerity - they were part of a transnational cycle of struggles for real democracy.

\section{Our Argument: Not Diffusion but Resonance}

The concept of diffusion has long been used by social scientists to describe the process by which certain ideas or practices are disseminated within or between countries. In his original formulation, Katz (1968: 178) described diffusion as "the acceptance of some specific item, over time, by adopting units - individuals, groups, communities - that are linked both to external channels of communications and to each other by means of both a structure of social relations and a system of value, or culture". Building on this formulation, social movement scholars have identified a number of elements that are essential to the process, namely: (1) a 'transmitter'; (2) an 'adopter'; (3) an 'item'; and (4) a 'channel' through which the item reaches the adopter from the transmitter. Most of the academic debate on diffusion has focused on what channels for diffusion matter more: the direct channel, by which diffusion occurs through pre-existing contacts between the transmitting and adopting movements (a process also referred to as relational diffusion); the indirect channel, through non-personal links like the mass media, social media, or word of mouth (non-relational diffusion); or a combination or interplay of the two (McAdam and Rucht 1993). Tarrow (2005) has further noted that diffusion can also be mediated by a third party fulfilling the role of a broker.

As this brief discussion reveals, the concept of diffusion hinges fundamentally upon a clear-cut distinction between the transmitter and the adopter, and assumes a linear relationship running from the former to the latter. In this chapter, we argue that these assumptions fail to capture the complexity of the pattern by which recent protest movements actually spread across such radically different contexts. Instead, we suggest that each of the national movements drew on a combination of: (1) shared indignation with the structural conditions of a deepening crisis of representation, and (2) pre-existing autonomous activist networks and extensive local movement experience with horizontal modes of self-organization. The occupations of public squares in Madrid, Athens, and New York took off thanks to the inspiration provided by multiple movements in other countries, whose perceived successes motivated protesters back home to translate their common grievances and local movement experience into action. Instead 
of assuming the adopter's mindless imitation of a 'transmitter' movement, we therefore switch our focus to the conscious process whereby endogenous potentialities for mobilization - which already lay dormant in each of the national contexts - are actualized through the inspiration drawn from successful movements elsewhere.

We refer to this process as a pattern of resonance. The concept of resonance is not new. In their 2008 pamphlet, The Coming Insurrection, the Invisible Committee already noted that "revolutionary movements do not spread by contamination, but by resonance. Something that is constituted here resonates with the shock wave emitted by something constituted over there" (p. 6). Seen in this light, protest movements are "not like a plague or forest fire - a linear process which spreads from place to place after an initial spark", but rather take the shape of sound waves, which, "though dispersed in time and space, succeed in imposing the rhythms of their own vibrations, always taking on more density" (ibid). Rather than a series of copycat movements that simply imitate the ideas and practices of some more innovative 'vanguard' movement elsewhere, we see shared structural conditions between - and historical continuities within - each of the local contexts. The combination of these shared structural conditions and pre-existing activist networks and local movement experience shapes the potentialities for mobilization, which can in turn be actualized through the inspiration provided by successful movements elsewhere. Note that 'successful' here does not necessarily refer to a particular movement achieving its declared objectives but rather to its immediate success in mobilizing a large segment of the population behind a common cause.

Holloway (2005) has described the phenomenon of resonance in similar terms in connection with the Zapatistas' influence on the global justice movement, arguing that "there is no linear progression here. It is not the spread of an organisation that we are speaking of [...] Neither is it really a question of the spread of an influence from Chiapas [...] It is rather a question of resonance and inspiration". Selbin (2009), meanwhile, has explained the spread of revolutionary movements through a comparable concept of mimesis, which, as opposed to mimicry, emphasizes how the struggle of a group in one place can provide revolutionaries elsewhere with the inspiration to start or intensify their own struggles back home. As Selbin notes, the process by which one movement inspires another is really quite simple, and was captured in a statement by a Nicaraguan Sandinista on the Cuban revolution: "if they can do it there, we can do it here." Knight describes essentially the same process when he speaks of a 'demonstration effect': 
The formula seems simple enough: in one place or more, people who perceive themselves oppressed learn of others who they can identify with who have sought to change the material and ideological conditions of their everyday lives; duly inspired, they too seek to make such fundamental and transformational changes. Again, it is worth noting that these may be their own ancestors, their contemporaries, or people in other places, perhaps nearby but at times far distant - one need look no farther than the great swath cut by the Paris Commune or the incredible resonance of the Cuban Revolution. (cited in Selbin 2009: 72)

As Knight points out, the resonance of this demonstration effect works not only through space but also through time. In fact, social movements may very well draw on inspiration provided by movements that preceded them within their own countries, as well as the immediate inspiration provided by ongoing mobilizations elsewhere. All of this goes to show how the linear concept of diffusion, running from the transmitter of an item to its adopter, may overlook a very basic affective process by which movements are simply inspired to take action by the (perceived) successes of another movement, while always building on local experience and networks to mobilize large groups of people.

\section{\#15M: "No-one Expects the Spanish Revolution"}

In trying to uncover the pattern of resonance behind recent anti-austerity protests, our story begins in Spain on 15 May 2011, when an independent and decentralized citizen platform called Democracia Real YA(DRY), constituted by a loose coalition of over 200 social groups and civil society associations, organized a large march in Madrid and 57 other cities throughout the country. Their aim was to protest the handling of the country's devastating financial crisis, the corrupting power of private banks over government, and the unwillingness of political representatives - and the inability of the political system more generally - to respond to the needs of the people. Under the slogan "We are not goods in the hands of bankers and politicians", up to 130,000 people took to the streets and made their voices heard in the single biggest protest march since the start of the crisis in 2007-2008 (Castells 2012). Deliberately unaligned with any political party, DRY effectively functioned as an organizing platform for a leaderless convergence of pre-established movements aimed at coordinating a broad-based citizen mobilization in defiance of the political and financial establishment. 
Up until that moment, the people of Spain had already suffered tremendous hardship as a result of the deflation of a massive housing bubble. More than one in five Spaniards and almost half of the country's young people were out of work, over 11 million people were at risk of falling into poverty, and hundreds of thousands of families had been evicted from their homes. Meanwhile, bank executives enjoyed impunity as their banks or cajas were bailed out by the government after years of reckless speculation in the housing market. A little before, in mid-2010, the socialist government of Prime Minister Zapatero had made a U-turn in its economic policies, shifting from a 'heterodox' stimulus package to an orthodox austerity budget, putting further stress on the already embattled lower and middle classes. With a nominally socialist government now pursuing essentially conservative economic policies, the conditions for widespread indignation were in place: the market-imposed shift towards austerity took away the last remaining grounds on which people could distinguish between the two mainstream parties - socialists and conservatives - thus undermining the appeal of electoral politics and making other forms of political intervention necessary.

As a number of recent surveys clearly illustrate, levels of public trust in the political system have fallen to historic lows since the start of the global financial crisis in 2008, and in particular the onset of the European debt crisis in 2010. A Eurobarometer survey found that, while it fell across the EU, public confidence in European institutions fell most dramatically in Spain: from 65 per cent in 2007 to 20 per cent in 2013, while mistrust was up from 23 per cent to 72 per cent (Traynor 2013). Another survey finds that, "compounding their doubts about the Brussels-based European Union, Europeans are losing faith in the capacity of their own national leaders to cope with the economy's woes" (Pew Research 2013). Similarly, the European Social Survey of April 2013 argues that sky-rocketing unemployment and a pervasive sense of social insecurity are responsible for "overall levels of political trust and satisfaction with democracy declining across much of Europe", noting that the trend is "particularly notable" in Spain and has reached "truly alarming proportions" in Greece (Economic and Social Research Council 2013: 16). In response to these findings, José Ignacio Torreblanca, an analyst for the European Council of Foreign Relations, remarked that "both debtor and creditor countries basically feel that they lost control of what they are doing" (Naumann 2013). He concludes that most Europeans "now think that their national democracy is being subverted by the way the euro crisis is conducted," providing evidence for a deepening crisis of representation (Traynor 2013). 
This is the structural background against which the initial DRY demonstration occurred on 15 May 2011. Following the official march, some clashes broke out between protesters and police during a sit-in in Gran Vía, after which a group of around 100 protesters marched on the city's iconic central square, the Puerta del Sol. Once there, around 20 of them formed a circle to discuss what to do next (conversation with Take the Square organizer in May 2012). At some point, one of the DRY organizers suggested to his companions that they should act like the Egyptians and camp out in the square that night (Elola 2011). Deciding that a coordinated march was not enough, the group accepted his proposal, which some later said could have been made by anyone else in the group, as it just seemed to be a logical evolution to the day's events (Take the Square organizer). That night, some 30 protesters camped out in Sol, and the next day, on 16 May the first official assembly was held (El País 2011). As the \#spanishrevolution hashtag went viral on Twitter, word reached Barcelona, where another group of protesters decided to occupy Plaça Catalunya.

In the early hours of 17 May, however, the authorities of Madrid made what turned out to be a fateful mistake: they tried to remove the protesters - whose numbers had swelled to 200 - from the square (Hernández and Arroyo 2011). The attempted forceful eviction, during which two people were arrested and one was injured, immediately backfired. Independently from DRY, the protesters who had camped out in Sol disseminated a viral call to action via Facebook, Twitter, and SMS: to gather in Sol at 8pm that evening in defiance of the authorities and in anticipation of an indefinite occupation. That evening, thousands of people gathered in Sol, some of whom organized into an impromptu assembly in which the decision was made to set up camp and occupy the square (Cortés 2011; Take the Square organizer). As the protest grew, Twitter and Facebook were abuzz with a straightforward imperative: ;Toma la Plaza! ('Take the Square!') That night, the assembly set up its different working groups and committees, appointing a communication team which quickly established links with the 30 other cities in which occupations were already under way. Again, hundreds of people stayed the night as a large tarp canopy was set up marking the start of a Tahrir-style tent camp. Acampada Sol was born. As one sign proclaimed: "No-one expects the Spanish revolution!"

Another sign, held up by a teacher, summed up everything that needed to be known about the movement's stance on traditional representative politics: "The young took to the streets and suddenly all the political parties got old". According to a reporter for El País who was embedded in the protest camp at Sol from the very beginning, 17 May "revealed the magic 
of spontaneity. The miracle of communication. The power of spreading the message through social networks. The strength of a new generation." (Elola 2011) "Tuesday the $17^{\text {th }}$ was magical," the El País reporter went on: "magical because nothing had been prepared. Fed by social networks, a spontaneous demonstration bloomed into existence. The $15 \mathrm{M}$ protests, by contrast, had been the fruit of conscious and conscientious labor. Three months of preparation. Tuesday was something else. Something new. Something different."

So where did this sudden rush towards "spontaneous" mass mobilization come from? Numerous commentators and activists have rightly stressed the precedent of the Egyptian revolution and the occupation of Tahrir Square. As one of our friends in Take the Square - who wishes to remain anonymous - put it, "Of course Egypt inspired us! The Egyptians showed us that it was possible to have a revolution without leaders. That it was possible to overthrow a regime through a non-violent occupation of a square. Of course that inspired us." (conversation in January 2013). But while Tahrir clearly played a seminal role in inspiring the decision to occupy Puerta del Sol, the idea that the $15 \mathrm{M}$ movement was therefore 'diffused' from Egypt and simply imitated the Egyptian revolutionaries seems overly simplistic. After all, the practice of occupying public space was not new to all the early participants in Acampada Sol, some of whom came out of the city's thriving Okupa ('squatters') movement (Flesher Fominaya 2013). Squats like Patio Maravillas, which describes itself as an "autonomously governed space" and which contains a "HackLab" that was seminal in building up the movement's communications resources, have been experimenting with the occupation of public spaces for decades. These hubs played a key role in providing experience and resources for the occupation of Sol.

Similarly, the idea of autogestión - or self-management - is well-established in Madrid and in Spain more generally. Apart from the country's well-known anarchist tradition of the 1930s, which continues to live on today in the anarcho-syndicalist union CNT (but which may not have had a very direct impact on the $15 \mathrm{M}$ movement), the 1960 s witnessed the blossoming of a strong movement of neighborhood associations in Madrid. Although these associations have since lost most of their radical flavor, the idea of neighborhood assemblies survived and was later reincorporated by the $15 \mathrm{M}$ movement following the voluntary disbanding of the protest camp at Sol. The consensus model of decision-making thus did not arrive at Sol out of a vacuum, nor was it adopted from abroad. Rather, it was endogenous to local movement experience and already institutionalized at an early stage in the decision-making model of the DRY platform as well 
as the movements and collectives that constituted the platform. One of the core groups in DRY, Juventud Sin Futuro (JSF, 'Youth Without Future'), was created in February 2011 and brought together dozens of movements and associations that had been involved in the student resistance against the Bologna process in 2008-2009. Many of these groups had been organizing through assemblies for years.

Furthermore, to think that Egypt was the sole source of inspiration for the movement would be a mistake. First of all, the protesters derived their name - the Indignados - from a short pamphlet by French resistance hero Stéphane Hessel entitled Indignez-Vous! (2010). Even if the media initially made the connection, the protesters themselves also adopted the name. Second, Fabio Gándara, the 26-year-old lawyer who set up the digital DRY platform with two friends, has claimed that he looked to Iceland's so-called "kitchenware revolution" for inspiration, as did two of the key organizers with Take the Square. After all, in 2009, after Iceland's banking sector collapsed, the small country experienced the largest protests in its history, leading eventually to the fall of its government, a re-writing of its constitution, and the prosecution of banks and politicians held to be responsible for the crisis. Does that mean that the $15 \mathrm{M}$ movement diffused from Iceland, and that Spain merely adopted Icelandic ideas or imitated Icelandic practices? Clearly such an assertion makes little sense. Rather, just like Egypt's leaderless struggle for democracy resonated with indignant Spaniards, so did Iceland's popular protests against the bankers and politicians. Others similarly took inspiration from Greece, where the resistance to austerity had been firing up with a number of general strikes, mass marches, and widely broadcast riots ever since May 2010. Tellingly, despite an unspoken ban on political symbols, the only flags visible at Sol were the Greek, Icelandic, and Spanish Republican flags - the latter indicating a degree of historical resonance with the anti-fascist resistance during the Spanish Civil War (1936-1939).

The Plataforma de Afectados por la Hipoteca (PAH, 'platform of mortgage victims') is another example of the multiple sources of inspiration that fed into the $15 \mathrm{M}$ movement. In late 2010, the platform started one of its most visible campaigns - Stop Desahucios - which was aimed at stopping or paralyzing foreclosures through direct action. This form of direct action, often involving occupations of properties about to be evicted, preceded the occupation of the public squares in 2011. Interestingly, the Madrid charter of the PAH emerged in close cooperation with CONADEE - the National Coordination of Ecuadorians in Spain - which struggles for the rights of Ecuadorian migrants. It is worth observing in this respect that Ecuador had 
a major financial crisis of its own in the late 1990s and early 2000s, feeding a wave of migration to Spain, where many Ecuadorians took up jobs in the booming construction sector. While the number of Ecuadorians in Spain stood at only 10,000 in 1998, it climbed to 200,000 in 2002 and hit 500,000 in 2005 (Weismantel 2008). When the Spanish housing bubble finally began to deflate in 2007-2008, many of these Ecuadorians lost their jobs and could no longer afford to pay their mortgages or rent. Since they were heavily affected by the crisis, and since they were well organized through CONADEE, and since they had already fled from one major debt crisis and could not afford to flee from another, the Ecuadorians proved to be a formidable force for mobilization in Madrid's social movement landscape.

In an interview with the authors, Aïda Quinatoa - spokeswoman for CONADEE, a key organizer in PAH Madrid, and an active participant in the $15 \mathrm{M}$ movement - recounted that she helped set up PAH Madrid on the basis of what she describes as indigenous Andean values: a communitarian ethos revolving around consensus decision-making. The PAH joined DRY two months before $15 \mathrm{M}$, because, as PAH spokesman Chema Ruiz recounted, they found in DRY a group of people loyal to the same horizontal and autonomous processes as their own - a group that organized through popular assemblies just like they had been doing for years. And, as would become clear later on, PAH and the DRY were far from the only ones.

\section{\#25M: "Be Quiet, or You'll Wake up the Greeks!"}

Our story continues in Greece, where on 23 February 2011 - months before the occupation of Puerta del Sol - yet another general strike took place, and yet another demonstration reached its final destination at Syntagma Square in front of parliament. As is common with such demonstrations, it began to dismantle after a short clash with riot police and the usual tear gas bombs, stun grenades, and Molotov cocktails.

At this point, Greece was still at the beginning of her self-destructive dance with the Troika of foreign lenders, made up of the European Commission, the European Central Bank, and the International Monetary Fund. The start of this dance had been signalled by Prime Minister Giorgos Papandreou's simple televised message from Kastelorizo island on 23 April 2010, and the second step was taken on 5 May 2010 with the signing of the first memorandum of understanding between Greece and the Troika. On that day, Athens and other major Greek cities witnessed large-scale protests 
that ended with the tragic burning down of the Marfin Bank in Stadiou Street, Athens, where three employees were burnt alive.

The demonstrations, riots, and general strikes continued throughout 2010 and 2011 as the Troika kept demanding ever-tighter austerity measures. At the demonstration and general strike of 23 February 2011, however, there was something different in the air. Inspired by the example of the occupation of Tahrir Square that had led to the overthrow of Egypt's President Hosni Mubarak just 12 days before, a group of people from a newly established small extra-parliamentary leftist party (MAA, or the Solidarity and Overthrow Front, which split off from the Coalition of the Radical Left, or Syriza), started encouraging protesters to "stay in the square like the Egyptians". The call, however, failed to build up momentum and was ultimately unsuccessful - not least because the sectarian nature of those calling for the occupation failed to resonate with the wider population. Still, anti-austerity protests continued, and another general strike took place just days before the Spanish occupied Puerta del Sol on 15 May 2011.

After 15 May, the news about the occupation of squares across Spain spread to Greece, initially through social media and later through the mainstream media as well. From the very first days, a number of Greeks who had been involved in the global justice movement and the December Uprising of 2008, and others who had personal contacts with people in Spain, started following the Spanish mobilizations, and the idea of something similar occurring in Greece slowly began to appear - first as a distant prospect, later as a serious possibility. "If they did it in Egypt and Spain, why can't we do it here?" the Greeks now seemed to think, inspired by their neighbors on the other side of the Mediterranean. From that moment onwards, discussions started taking place among activists and previously apolitical citizens, not necessarily to 'imitate' the Spaniards but rather to adress a widespread feeling that the structural conditions in Greece were even worse, and that a massive reaction of the people was an absolute necessity. After all, as we saw before, the decline of "overall levels of political trust and satisfaction with democracy" had reached "truly alarming proportions in Greece" (Economic and Social Research Council 2013: 16).

While news about the Spanish Indignados continued to spread through social media, and while the mass media also slowly started making references to the protests in Spain, a group of Spanish expats living in Greece - mainly students but also workers who had not directly participated in $15 \mathrm{M}$ but whose friends and relatives had - organized the first demonstrations in solidarity with their compatriots outside the Spanish embassy in Athens. In Athens, as elsewhere, the call to action was made through Facebook, and 
the first to join the solidarity protests were some Greeks who happened to be in the Spanish community networks (students, friends, and co-workers), and some activists from the anarchist groups of Athens. The first action took place on 20 May 2011 and soon moved to a nearby area in Thisio. There, the Spanish-Greek assembly was set up and the protesters divided into thematic groups. Some of the participants also brought their tents and spent the night, forming a small acampada. The big issue was how to attract more people and achieve a scale shift towards mass mobilization. With that aim in mind, the group decided to set up a website, discussed the best domain name, and ended up picking real-democracy.gr. The website was set up within a day and immediately attracted 6,000 visitors in its first 24 hours.

Around the same time, a 'rumor bomb' began to circulate on social media networks: one of the banners or slogans of the Indignados was rumored to have urged protesters in Spain to "be quiet, or else you'll wake up the Greeks". No photograph or any other form of proof of this claim ever appeared anywhere, but the mass media in Greece soon picked up on the story and reproduced the news. It worked. After a group of people from Thessaloniki created a Facebook page for the occupation of Lefkos Pyrgos and another one for Syntagma and other squares throughout the country

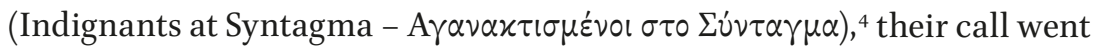
viral. A few days later, on 25 May, a peaceful anti-austerity demonstration ended at Syntagma and occupied the square. The occupation of Syntagma was to last for 72 days and nights, from 25 May until 30 July 2011. Indicating how the movement's deliberate and self-conscious autonomy from the political system directly arose from the deepening crisis of representation, Dimitris - a mathematics tutor and playwright who would later evolve into a respected facilitator of the Syntagma Popular Assembly - told us that: "because it wasn't a call from a political party or from a union, I thought here there might be something happening from the people. That's why I participated." (interview in March 2012).

4 The Greek movement of the squares is often referred to as the aganaktismenoi, or the Greek Indignados. It should be mentioned that this name was coined by the media, which saw Syntagma as a copy of Sol. The movement itself never really accepted this term. While the Facebook page calling for the occupation was called 'Indignants at Syntagma', the people who made the call were not the ones who actually occupied the square. For that reason, following a suggestion at the Syntagma Popular Assembly on 31 May 2011 (Syntagma Popular Assembly, 2011), a huge banner was unfurled over the square reading: "We are not indignant, we are determined!" The banner remained there for the duration of the occupation, highlighting the Greeks' self-conscious refusal to simply 'emulate' their Spanish counterparts. 
So how did the occupation adopt its autonomous, horizontal, and direct democratic model of decision-making? Dimitris was unequivocal about the movement's sources of inspiration: "what happened in Egypt, what happened in Spain - it's not irrelevant for what happened here in Greece. Or what's happening now. Or what's going to happen." Like Niki, a young activist who participated in both the $15 \mathrm{M}$ movement in Spain and the movement of the squares in Greece, Dimitris similarly stressed how the struggle of the Egyptians and Spaniards resonated with the revolutionary desires of many Greeks. At the same time, however, to claim that the movement was therefore diffused from Spain or Egypt would again be overly simplistic. For one, Greece's social movements themselves have extensive experience with direct democracy and self-organization, and Athens had a well-formed pre-existing network of autonomous activist collectives, ranging from the city's well-known anti-authoritarian movement centered around the anarchist neighborhood of Exarchia to the various offshoots of the global justice movement - including the No Border Camps and other migrant rights movements and civil society organizations - many of which have been organizing through assemblies for years.

After Syntagma was occupied, a large banner was unfurled outside the Spanish Embassy - and later in front of parliament - reading: $i$ Estamos despiertos! ¿Que hora es? ¡Ya es hora de que se vayan! ('We are awake! What time is it? Time for them to go!'). The reference was not only to Spain, but also to the famous slogan of protesters in Buenos Aires during the Argentine crisis of 2001-2002: ique se vayan todos! ('Away with them all!'). Another very popular slogan at the square was "One magical night, just like in Argentina, let's see who will get on the helicopter first!", referring to the escape of President De la Rua from the Presidential Palace following the spontaneous popular uprising of 19 and 20 December 2001 in Buenos Aires. Meanwhile, the crowd-funded Greek documentary Debtocracy was being screened in the square, detailing the experience of Ecuador and how the pressure of social movements there helped the country to repudiate its odious debt. During protests, slogans like "Bread, Education, Freedom!" - borrowed from the occupation of the Athens Polytechnic in 1973 which marked the beginning of the end of the dictatorship of the colonels - were regularly chanted by the protesters, indicating the historical resonance of past grassroots struggles for democracy. In a word, multiple sources of inspiration simultaneously converged upon the square.

Within days, the nightly protests in front of parliament swelled to over 100,000 protesters for several nights on end. Although the exact numbers remain very difficult to calculate, it is estimated that as many as 2.6 million 
people either 'occupied' or 'passed by' - but in any case experienced Syntagma Square in those days, constituting half of the population of Attica, the administrative region to which Athens belongs (Sotiris 2011 cited in Leontidou 2012). From the very first day of the occupation at Syntagma, a general assembly was organized in the square. The group that had previsouly set up camp in Thisio, having the experience and the equipment of the previous days, provided the microphone set-up and the first facilitators. The anarchists of Exarchia, who were initially reluctant to join the protests because of their seemingly 'apolitical' character, later did join in and brought a better sound system to facilitate the assemblies and live concerts. In Athens, the anarchists' influence on the occupations appeared to be stronger than in Madrid - something that was illustrated in the refusal of the Greeks to embrace the "real democracy now" slogan, which many argued could be wrongly construed as a liberal argument for a properly functioning representative democracy. Instead, the Greeks embraced the more explicitly anarchist-inspired slogan "direct democracy now" (Sotirakopoulos and Sotiropoulos 2013).

The General Assembly of Syntagma and its thematic working groups summarized their demands in two claims: (a) cancel the memorandum of understanding and prevent the vote on the mid-term agreement of $29 \mathrm{June}$ 2011; and (b) 'real, direct democracy' in the country, since the representative parliamentary system was seen as having become submissive to local and foreign financial interests. Although the first demand was restricted to the Greek political reality of the time, the second transcended national borders. Of course, the General Assembly of Syntagma Square was not fully aware of what direct democracy exactly was, how it could be achieved, whether it could be practised on a large scale - beyond a small village or a square - and so on; but what the protesters did know was that the current system simply did not represent them, and that some kind of alternative had to be devised. And so, in their quest for real democracy - and in between other initiatives directed towards the more urgent first demand - the square embarked on a journey to "discover and explore" a new model, directly experimenting with consensus decision-making in the assemblies and organizing educational initiatives detailing the experiences of other autonomous movements. In the spring and summer of 2011, Syntagma essentially reflected Holloway's summary (1996) of the Zapatista motto: preguntando caminamos ('asking we walk').

One such initiative was organized on 17 June 2011, the "Day of Popular Information and Discussion on Direct Democracy". Apart from the academics invited to speak on the issue, there were also two speakers who had some 
practical experience with direct democratic experiments: WWII resistance hero Manolis Glezos, who had practised direct democracy in his village on Naxos island while he was mayor there, and Professor Stavros Stavridis, who had come across the Zapatista reality while involved in the 'School for Chiapas' campaign - highlighting the existence of both local experience and inspiration from abroad. The Zapatista experience was discussed at least once more at Syntagma, on 8 July 2011, with the main speaker (via Skype) being the well-known Mexican activist Gustavo Esteva. Given this recurrent interest in living examples of direct democracy, the Greek movement of the square - like its counterpart in Spain - went far beyond being a mere anti-austerity protest: it began to actively explore alternatives to liberal democracy, openly experimenting with autonomous and horizontal modes of self-organization.

\section{\#27S: “America's Tahrir Moment”}

At some point in early July 2011, while we were embedded in the Multimedia Team at Syntagma Square writing daily reports for ROAR Magazine and assisting in the coordination of transnational actions - like the upcoming global day of action of 15 October - and the dissemination of information to other movements elsewhere, we received an email on the Take the Square account. It was Micah White, senior editor of the Canadian activist magazine Adbusters. Micah had an important piece of information to share with us: together with editor Kalle Lasn, he was about to launch a 'tactical briefing' to the 90,000-strong Adbusters network calling for the occupation of Wall Street. Kalle and Micah now wanted advice from European activists on how to bring about the kind of scale shift required for such an occupation.

As with the occupations of Sol and Syntagma, the call to Occupy Wall Street did not arise out of a vacuum. Just as in Europe, there has been a long-term trend in the United States of declining levels of public trust in political leaders and institutions - a trend that was gravely intensified by the handling of the 2008 financial crisis. At the time of writing, Gallup's most recent annual trust poll found that only 19 per cent of Americans trust the government to do what is right "just about always" or "most of the time", while 81 per cent trust the government to do what is right only "some of the time" or "never" (Gallup 2013). The same numbers stood at 32 per cent and 67 per cent, respectively, during George W. Bush's second term. Going back even further, to 1960, 73 per cent of Americans still believed their government would do the right thing "just about always/most of the time". 
Less than half the American population now trusts the federal government to handle international and domestic problems, marking a 25-point decline since Gallup first asked the question in 1972, while 66 per cent are convinced that legislators "never" or only "some of the time" do the right thing - marking an inversion from 2002, when public trust in legislators stood at 67 per cent. Two leading pollsters for former Presidents Bill Clinton and Jimmy Carter remark that "this harrowing lack of trust in confidence in politicians and institutions today has been a long time coming [...] As it stands, our system only serves the elite, not the mass public. And the American people know it." (Schoen and Caddell 2013: online).

As in Greece and Spain, part of the Americans' frustration with the Democratic government may reside in the fact that a nominally progressive or center-left government ended up following an essentially conservative neoliberal policy package, thus leaving little to no room for distinction between the dominant political parties. President Obama, who had mobilized a large contingent of grassroots liberal activists to support him in his first election campaign, in fact reproduced and intensified many of the policies of the Bush era, most notably the massive Wall Street bailouts and the failure to bring about meaningful financial reform, thus leaving the economic problems of most Americans largely unaddressed, condemning millions to unbearable levels of student, mortgage, credit card, and medical debt. Even though the federal government and the Federal Reserve remained committed to a mild form of fiscal and monetary stimulus, at the municipal and state level, austerity budgets were already starting to bite. This trend first came to light in California in 2009, where budget cuts in education at the state level and large losses in university endowments following the Wall Street meltdown forced the University of California Board of Regents to announce a 32 per cent rise in tuition fees, sparking a wave of student protests and campus occupations across the state. An influential text written by the Research and Destroy collective at UC Santa Cruz, Communiquéfrom an Absent Future, resonated widely among America's "graduates without a future" (Mason 2013).

The California student protests of 2009 were not the only anti-austerity mobilizations in the US to precede Occupy. In June 2011, a coalition of NGOs and movement organizations called New Yorkers Against Budget Cuts made a call to action to set up a protest camp - nicknamed 'Bloombergville' in reference to New York City mayor Michael Bloomberg - in City Hall Park, New York, vowing "to stay till Bloomberg's budget is defeated" (NYABC 2011). The Bloombergville initiative, in turn, was inspired by the Walkerville occupation that had been staged by workers in Wisconsin earlier in June. 
Wisconsin was itself emerging from the 100,000-strong labor union protests that had taken place in February following Governor Walker's move to abolish collective bargaining rights as part of a radical new austerity budget. The occupation of Wisconsin's State Capitol occurred around the same time as the Egyptian revolution and strongly resonated with it. And in July 2011, a coalition of social movements and organizations called Anticut organized a series of anti-austerity marches in the San Francisco Bay Area. A group of explicitly anti-capitalist activists in Oakland - called 'Bay of Rage', in reference to Egypt's Day of Rage - released a communiqué stating the following:

Now, finally, the money is gone. The world has run out of future, used it up, wasted it on the grotesque fantasies of the rich, on technologies of death and alienation, on dead cities. Everywhere the same refrain, the same banners and headlines: there is nothing left for you. From the US to Greece, from Chile to Spain, whatever human face the State might have had: gone. The State is no longer a provider of education or care, jobs or housing. It is just a police force, a prison system, a bureaucracy with guns. (Bay of Rage 2011)

On 9 June, a month before Micah White contacted Take the Square and launched the call to Occupy Wall Street, Adbusters had already emailed its followers arguing that "America now needs it own Tahrir". Greece, Spain, and Egypt thus had a clear influence on activists on the other side of the Atlantic. Indeed, according to Micah White and Kalle Lasn, "the spirit of this fresh tactic, a fusion of Tahrir with the acampadas of Spain" was captured in a quote by professor and Barcelona-based activist Raimundo Viejo: "The anti-globalization movement was the first step on the road. Back then our model was to attack the system like a pack of wolves. There was an alpha male, a wolf who led the pack, and those who followed behind. Now the model has evolved. Today we are one big swarm of people" (Adbusters 2011). Meanwhile, Micah and Kalle deliberately distanced themselves from the organizing process in New York so as to avoid being seen as leaders: "our role [...] could only be [...] to get the meme out there and hope that local activists would empower themselves to make the event a reality," Micah White told David Graeber (2013: 36). In a way, Adbusters simply fulfilled the same function as the group of Thessaloniki activists who set up the Facebook page with the call to occupy Syntagma Square.

David Graeber (2011a, online) has recounted in great detail the process that led up to the actual occupation of Zuccotti Park. In the early days, on 
2 August, Graeber responded to an invitation by a Greek anarchist to join a 'General Assembly' at Bowling Green, where a discussion was to be held on how to respond to Adbusters' call to action and organize for the Wall Street protest on 17 September. Once he arrived there, however, he found a meeting that had been 'hijacked' by a group of veteran protesters associated with the Worker's World Party (WWP). Far from being interested in a genuine leaderless assembly, the group imposed its own hierarchical structures and demands on those assembled. Speech after speech was held dictating to participants the rules and terms of the protest that was to be held. Fed up, Graeber and a number of friends he recognized from his time in the global justice movement decided to break away and form their own circle at the margins of the meeting and hold an assembly:

We realized we had an almost entirely horizontal crowd: not only Wobblies and Zapatista solidarity folk, but several Spaniards who had been active with the Indignados in Madrid, a couple of insurrectionist anarchists who had been involved in the occupations at Berkeley a few years before, a smattering of bemused onlookers who had just come to see the rally, maybe four or five, or an equal number of WWP (not including anyone from the central committee) who reluctantly came over to monitor our activities... (Graeber 2013:36)

Eventually, this group of 'horizontals' managed to draw most participants in the meeting away from the WWP, with its hierarchical and centralized leadership, and organized itself into the New York General Assembly (NYGA), which was to become the key decision-making platform for Occupy Wall Street. The assembly quickly made a couple of key decisions that were to determine much of the movement's nature and course over the months to come. During the NYGA's regular meetings in Tompkins Square Park, which featured "a smattering of activists who had been connected to the global justice movement" and a large group of younger participants "who had cut their activist teeth on the Bloombergville encampment" earlier that summer, it was decided that "what we really wanted to do was something like had already been accomplished in Athens, Barcelona, or Madrid: occupy a public space to create a New York General Assembly, a body that could act as a model of genuine, direct democracy to counterpose to the corrupt charade presented to us as 'democracy' by the US government” (Graeber 2011a).

As a result of this rejection of representative institutions, numerous participants and observers have noted the anarchist roots of the Occupy 
movement, as well as its continuities with the similarly anarchist-inspired global justice movement (Graeber 2011b, 2011c, 2002). It may be noted that these anarchist roots were both organizational, reflected in the movement's direct democratic principles and practices, and personal, arising from the presence of anarchists and anarchist-inspired activists among the core group of organizers. Sociologist Williams (2012) thus notes that "the most immediate inspiration for Occupy is anarchism" and even goes so far as to claim that anarchism forms the very "DNA" of the movement. Similarly, taking note of the somewhat curious nature of the "We are the 99\%" slogan, Paolo Gerbaudo has identified the ideology of contemporary movements like Occupy and the Indignados in a non-pejorative sense as "anarcho-populism" (2013). Anarchism, then, with its long history of revolutionary struggle against both capital and the state, and with its embrace of autonomy and horizontality as key organizational principles, can be understood as an increasingly dominant trend within contemporary anticapitalist movements, not least the ones in Spain, Greece, and the United States discussed in this chapter.

The claim that Occupy Wall Street was somehow diffused from a single transmitting movement like the Spanish Indignados therefore seems to overlook the multiple sources of inspiration that simultaneously converged upon New York's activist community as well as the latent potentialities for mobilization that already lay dormant within the US context. To be sure, there was a degree of relational diffusion here, as Spanish expats who participated in the occupation of Puerta del Sol were also actively involved in the core group of Occupy organizers (Romanos 2013). But there were also Greek anarchists involved as well as Zapatista-inspired autonomists, ex-occupiers from Bloombergville, and former alter-globalization veterans. The convergence of these multiple sources of inspiration, combined with the existence of pre-established autonomous activist networks and local horizontal movement experience, produced an interesting blend of ideas and tactics that appears to defy the somewhat simplistic linearity of classical diffusion theory.

And so, during a global day of action against the banks on 17 September 2011 - coordinated internationally by Take the Square, Global Revolution, and several other activist collectives $-5,000$ protesters stormed into Lower Manhattan and set up camp in Zuccotti Park. As OccupyWallSt.org, the unofficial website for the New York-based movement, later put it, OWS sought to "[fight] back against the corrosive power of major banks and multinational corporations over the democratic process, and the role of Wall Street in creating an economic collapse that has caused the greatest 
recession in generations". Two days after the occupation at Zuccotti took off, Lasn and White (2011) wrote an op-ed for The Guardian with a title that said it all: "The call to Occupy Wall Street resonates around the world."

\section{A Lesson in Democracy}

Several important conceptual and theoretical questions arise from this empirical discussion that seem to challenge the capacity of classical diffusion theory to explain the way in which anti-austerity protests spread across Europe and the United States. If the activists in Spain, Greece, and the US all claim that they were inspired by several other movements from within their own countries as well as from abroad, to what extent is it still justified to continue speaking of a linear relationship between a single transmitter and a series of imitating adopters? If, as the linear conceptualization of diffusion would have it, the occupation of Puerta del Sol diffused from the occupation of Tahrir Square; Syntagma from Sol; and Zuccotti from Syntagma (or was it Sol?), then where did the protests and occupations in over 1,000 cities and 80 countries on 15 October 2011 diffuse from? If the movements we examined above drew inspiration from multiple sources and arose in a shared structural context that instils in all a shared sense of indignation with ruling elites and political institutions, and if these movements in turn helped to inspire others elsewhere, performing both the role of the transmitter and adopter, to what extent does it make sense to pose a stark division between the two? How far, in other words, can classical diffusion theory really take us?

In order to overcome these conceptual and theoretical challenges, we propose - at least in the case of the post-2011 cycle of struggles - to move beyond the linear view of diffusion in favor of the non-linear concept of resonance. As we theorized in this chapter, and as our empirical discussion further illustrated, the transnational resonance of social mobilization is closely connected to the existence of shared structural conditions that connect grievances and ease the mutual identification between geographically and historically distant struggles. It also depends on the existence of local horizontal movement experience and pre-formed autonomous activist networks that can activate their own latent potentialities for mobilization by harnessing the 'shock wave' emitted by movements elsewhere, translating shared indignation into concrete action. Drawing on both a local dimension highlighting the latent potentialities for mobilization and a transnational dimension highlighting shared structural conditions and foreign sources 
of inspiration, the concept of resonance may help overcome some of the rigidities of a purely linear account.

All of this, however, still leaves us with a bigger question: if the movements we discussed here all claim that political and corporate elites do not and cannot represent them - that capitalist democracy is in fact not really democratic at all - then is it really justified to merely speak of a series of 'anti-austerity protests', or can we identify something more substantive in these mobilizations? In our empirical discussion, we briefly tried to show that the occupations in Madrid, Athens, and New York each contained both a negative and a positive element: they were at once a rebellion against austerity and a mobilization for autonomy and real, direct democracy. Whether a lasting transnational movement will emerge out of these mobilizations is another question, but what seems clear is that citizens in these three countries were asking themselves the same questions at roughly the same time: if austerity erases our future, and capitalism is inherently anti-democratic, then what is real democracy? And how can we mobilize and organize ourselves in order to bring such real democracy about, even if only temporarily in prefigurative form?

Some have noted that the general assemblies at Sol, Syntagma, and Zuccotti Park - marking a sort of return to the old Athenian model of the polis - may be a seedling of real democracy. More recently, these experiments in horizontality have been joined by the neighborhood forums in Istanbul, the assemblies in Brazil, and the 'plenums' in Bosnia and Herzegovina. So is that real democracy? We asked Manolis Glezos, the respected 91-year-old WWII resistance hero, direct democracy advocate, and anti-austerity campaigner, who is now an MP for the Coalition of the Radical Left (Syriza) in Greece. To our initial surprise, Glezos's stern reply was: "No. This is not democracy. How can a few thousand people assembled in a square claim to speak on behalf of the millions that live in the region?" But, Glezos continued, "it is a lesson in democracy. If this movement is to survive, its direct democratic models will need to spread to the neighborhoods and the working places". For real democracy to stand a chance, in other words, the movements will have to do a lot more than occupy a square: they will have to revolutionize productive social relations and the material basis of everyday life. In this sense, 2011 was really only just a beginning. 


\section{Bibliography}

Adbusters. 2011. '\#OCCUPYWALLSTREET', Adbusters, July 13.

Bay of Rage. 2011. 'Austerity is Prison: Communiqué from Anticut 3'. Retrieved 28 February 2014 from http://www.bayofrage.com/featured-articles/austerity-is-prison/.

Castells Manuel. 2012. Networks of Outrage and Hope: Social Movements in the Internet age. Cambridge: Polity Press.

Cortés Iker. 2011. "Miles de "indignados" toman la Puerta del Sol por un cambio político y financiero', El Diario Montanes, 15 May.

Economic and Social Research Council. 2013. 'Europe survey shows work and well-being impact of recession', European Social Survey, 22 April.

Elola Joseba. 2011. 'El 15-M Sacude el Sistema', El País, May 22. Translated by Jerome Roos as: '15-M movement shakes the system', ROAR Magazine, 24 May.

El País. 2011. 'Sol power: the 15-M story so far', El País, 4 August.

Flesher Fominaya Cristina. 2013. 'The Indignados as Autonomous Movement: Tracing Movement Continuity from the Global Justice Movement', Conference "Street Politics in the Age of Austerity", Montreal, 21 February.

Gallup. 2013. 'Trust in Government', Retrieved 28 February 2014 from http://www.gallup.com/ poll/5392/trust-government.aspx.

Gerbaudo Paolo. 2013. 'When anarchism goes pop', Open Democracy, 6 November.

Graeber David. 2011a. 'On Playing by the Rules: the Strange Success of Occupy Wall Street', Naked Capitalism, 19 October.

—. 2011b. 'Occupy and Anarchism's Gift of Democracy', The Guardian, 15 November.

-. 2013. The Democracy Project: A History, a Crisis, a Movement. New York: Spiegel \& Grau.

Hernández Maria, Arroyo Marta. 2011. 'La policía dispersa a los manifestantes de Sol, que anuncian más protestas', El Mundo, 17 May.

Hessel Stéphane. 2010. Indignez-Vous! Barcelona: Indigène.

Holloway John. 1996. 'The Concept of Power and the Zapatistas', Common Sense, 19.

-. 2005. 'Zapatismo Urbano', Humboldt Journal of Social Relations, $29: 1$.

Invisible Committee. 2008. The Coming Insurrection. London: MIT Press.

Katz Elihu. 1968. 'Diffusion (Interpersonal Influence)', in Sills David L. and Merton Robert K. (ed.), International Encyclopedia of the Social Sciences. London: Macmillan and Free Press, 78-85.

Leontidou Lila. 2012. 'Athens in the Mediterranean "movement of the Piazzas" Spontaneity in Material and Virtual Public Spaces', City, 16 (3): 299-312.

Mason Paul. 2013. Why It's Still Kicking Off Everywhere: The New Global Revolutions. London \& New York: Verso.

McAdam Doug, Rucht Dieter. 1993. 'The Cross-National Diffusion of Movement Ideas', Annals of the American Academy of Political and Social Science, 528 (1): 56-74.

Naumann Nils. 2013. 'Trust in European Union hits record low', Deutsche Welle, 26 April.

Pew Research. 2013. 'The new sick man of Europe: The European Union', Pew Global Attitudes Project, 13 May.

Romanos Eduardo. 2013. 'From Tahrir to Puerta del Sol to Wall Street: A Comparison of two Diffusion Processes within the New Transnational Wave of Protest', talk given at the conference entitled "Street Politics in the Age of Austerity" in Montreal, 21 February.

Roos Jerome, Oikonomakis Leonidas. 2014. 'They Don't Represent Us! The Global Resonance of the Real Democracy Movement from the Indignados to Occupy', in Della Porta, Donatella, 
Mattoni Alice (eds.), Spreading Protest. Social Movements in Times of Crisis. Colchester: ECPR Press, 117-136.

Schoen Douglas E., Caddell Patrick H. 2013. 'America's Crisis of Trust', Politico, 1 December.

Selbin Eric. 2009. Revolution, Rebellion, Resistance: The Power of Story. London: Zed.

Sotirakopoulos Nikos, Sotiropoulos George. 2013. 'Direct Democracy Now: The Greek Indignados and the Present Cycle of Struggles', Current Sociology, 61 (4): 443-456.

Syntagma Popular Assembly. 2011. 'Syntagma Popular Assembly's Minutes', Syntagma Square, Athens.

Tarrow Sidney. 2005. The New Transnational Activism. New York: Cambridge University Press. Traynor Ian. 2013. 'Crisis for Europe as trust hits record low', The Guardian, 24 April.

Weismantel Mary J. 2008. 'Ecuadorian international migration', in De La Torre Carlos, Striffler Steve (eds.). The Ecuador Reader. Durham: Duke University Press.

White Micah and Lasn Kalle. 2011. 'The call to occupy Wall Street resonates around the world', The Guardian, 19 September.

Williams Dana. 2012. 'The anarchist DNA of Occupy', Contexts, 11 (2). 



\section{Part 4}

When the Crisis Is not Enough 



\title{
10 Camps as the Sole Symbolic Expression of Protest
}

\author{
The Difficulties of Occupy in Ireland
}

Clément Desbos and Frédéric Royall

Shortly after the start of Occupy Wall Street (OWS) in New York City, a number of people set up similar camps in Dublin in early October 2011. Following Dublin's lead, Occupy-style campaigns were soon established in some of the Republic of Ireland's major cities such as Cork, Galway, Limerick, and Waterford. ${ }^{1}$ Though varying in size and in intensity - the occupations lasted from between several weeks in the case of Limerick to seven months in that of Galway - protesters in each of these cities occupied public spaces in community-like encampments and mounted rallies and demonstrations attended by citizens numbering anywhere from several dozen to several hundred people.

As in New York, Madrid, Buenos Aires, and London, Irish Occupiers expressed their anger and frustration over a number of social and economic issues. In Ireland, this concerned issues such as falling incomes, declining living standards, and crippling public and private indebtedness arising from the 2008 economic crisis. What compounded the situation in Ireland was the gradual but consistent retreat of the state from many of its social welfare commitments combined with the adoption of neoliberal privatization practices, especially during the post-1995 'Celtic Tiger' years. But however novel Occupy movements may have been around the world (Pickerill and Krinsky 2012), Irish occupiers struggled to gain widespread public support despite some initial displays of solidarity. The mainstream media dedicated some print space and air time to the Indignados in Spain, to the Arab uprisings, and to OWS but devoted little space and time to the home-grown Occupy campaigns. When it did, the media overwhelmingly portrayed the Irish occupiers as irrational activists fueled by anger, despair, and frustration. Overall, occupiers sought to challenge such dominant depictions by justifying or clarifying their actions to a wary and skeptical 
public. But despite such noble efforts, we argue that their efforts were of limited impact and fraught with difficulties.

This chapter is based on field research carried out between October 2012 and November 2014. During this period, we interviewed former Occupy leaders and activists from Limerick, Galway, and Dublin as well as union leaders, community organizers, media figures, and political activists. We also carried out participant observations in protest marches organized by Occupy Galway and spin-off organizations in this city in November 2012. And finally, we systematically analyzed occupiers' printed, audiovisual, and electronic documents (blogs, minutes, protest videos, correspondence, etc.).

The chapter is divided into two parts. The first section briefly reviews the country's recent social and economic context as a backdrop to the camps' establishment. The following section describes Occupy Galway and Occupy Dame Street (ODS) in Dublin and presents some of their key internal characteristics - non-hierarchical structures, sociological diversity, loose network relations, etc. The final section reviews some of the dominant ways the camps and activists were depicted, and considers the occupiers' frames of experience and representations so as to assess ODS and Occupy Galway's political significance.

\section{Social and Economic Context}

Compared to the historically lethargic performance dating from independence in the early 1920s, Ireland's economy underwent a remarkable transformation during the 1990s. By 2000, economic growth was averaging 10 per cent per annum, and there was a solid budget surplus and a very low ratio of debt to gross domestic product (GDP). Emigration - the country's perennial nemesis - had virtually disappeared and had been replaced by very strong immigration flows from forthcoming European Union accession countries such as Estonia, Lithuania, Poland, and Slovakia. By the end of the decade, however, the high-growth and high-performing economy had fallen into a macro-economic abyss. The Celtic Tiger housing boom, the backbone of the high-growth and high-performing economy, had been transformed into a property market bubble through excessive and reckless credit creation. Buoyed by strong property-related taxes, successive profligate coalition governments - led by Fianna Fáil from 1997 to 2011 - over-spent and under-taxed, thus contributing to the overheated property market bubble (Donovan and Murphy 2013). Few political leaders recognized and/or heeded the danger signals because the prevailing neoliberal economic ideology 
suggested that financial markets could regulate themselves. Blinded by his government's achievements, the prime minister responded to criticism with arrogance. ${ }^{2}$ But in the face of the unprecedented economic collapse in September 2008, the coalition government provided highly controversial - and ultimately ruinous - comprehensive guarantees on all deposits and borrowings for six troubled Irish-owned banks. ${ }^{3}$ Despite the guarantees, economic growth had plummeted by 2010, the budget deficit had spiralled out of control, the debt-to-GDP ratio had risen to over 100 percent, and unemployment had increased sharply (see Figure 10.1). ${ }^{4}$ As the comprehensive guarantees proved to be insufficient, the government was left with no alternative, according to some commentators, but to apply for an emergency $€ 85$ billion (US\$113 billion) rescue package in November 2010 from the so-called Troika: the European Commission, the European Central Bank, and the International Monetary Fund. In a catastrophic reversal of fortune, the property market bubble led to the Celtic Tiger's fall and the Republic entered the most unprecedented and traumatic period in its short economic and financial history.

In the context of growing economic and financial difficulties, the government was obliged to impose a series of austerity measures such as tax increases, reductions in public spending, salary restrictions in the public sector, and limits on social welfare entitlements. To some critics, the rise and demise of the Celtic Tiger were the result of long-standing free-market decisions based on the slavish adoption of a neoliberal agenda that set greater importance on kowtowing to international capitalist investors - and subsequently on reimbursing the international banking creditors - than on the needs of the Irish people (Kirby 2010). Such critics also saw the

2 "My message to you this morning is about confidence for the future. Confidence, in the strength of the economy that we have created together over recent decades. [...] Confidence, in our own judgement in the face of commentators and others who regularly cast doubt, not only on our future, but even on the reality of our past achievements [...] There are those who believe that our recent successes are an illusion. That they will disappear and we will be back to the natural order, an Ireland of unemployment and under-achievement. Some of these voices were telling us, not so long ago, that our approach was all wrong. [...] They were wrong then, and they are still wrong. [...] Sitting on the sidelines, cribbing and moaning is a lost opportunity. I don't know how people who engage in that don't commit suicide". Bertie Ahern, Taoiseach, Irish Congress of Trade Unions, Bundoran, 4 July 2007.

3 The banks covered were the Allied Irish Bank, the Bank of Ireland, the Anglo Irish Bank, the Irish Life \& Permanent, which owned Permanent TSB, the Irish Nationwide Building Society, and the Educational Building Society.

4 For an overview of the 2008 crisis and its international ramifications, see Ross's chapter in this volume. 
Figure 10.1 Unemployment in Europe (2007-2012): Percentage of total labor force

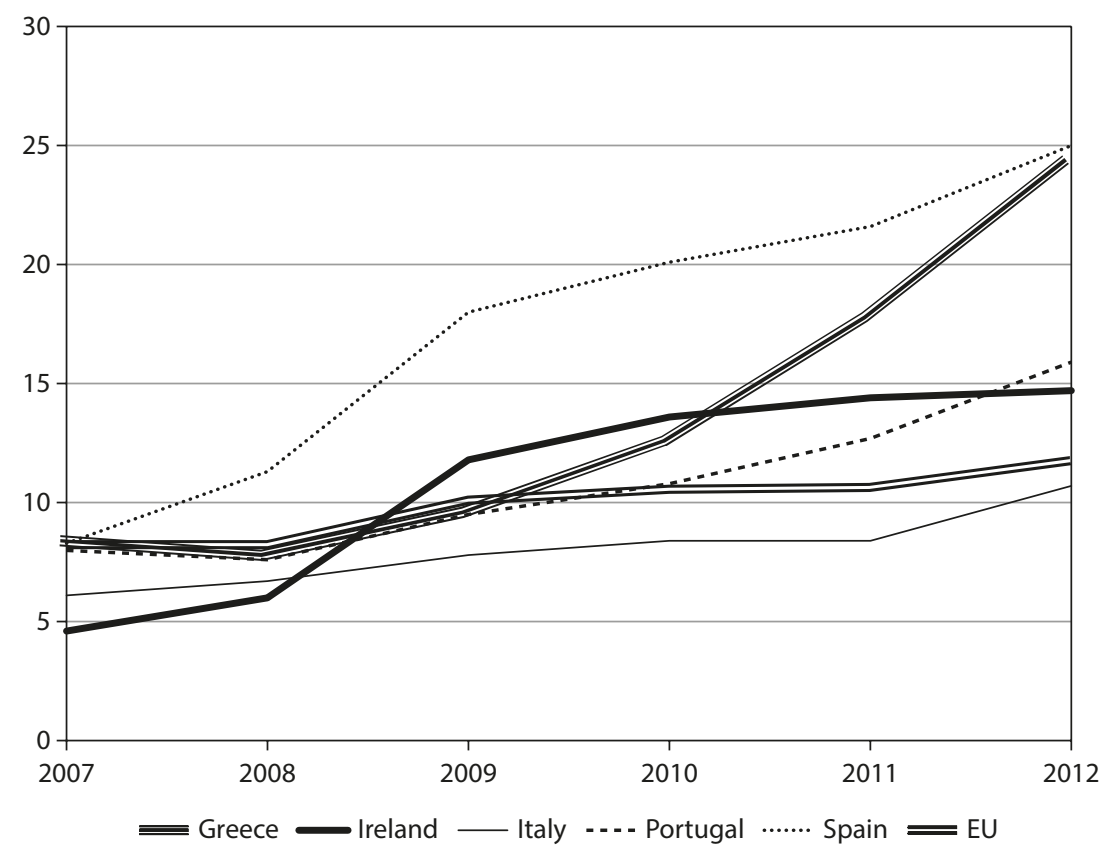

emergency rescue package as imposing a significant burden on the most vulnerable members of society.

The austerity and reimbursement measures - imposed first by the bank guarantees and then by the Troika's emergency rescue package - led to an unprecedented number of anti-austerity demonstrations organized by the Irish Congress of Trade Unions. For example, 120,000 people marched in Dublin on 21 February 2009, ${ }^{5}$ and 100,000 did so on 27 November $2010^{6}$. Also significant is that a number of demonstrations and marches were organized independently of the trade union movement. These protesters focused essentially on the government's cost-saving measures: the reduction in the number of people entitled to medical cards, the reinstatement of third-level fees, the cuts in pension entitlements, the reduction in the number of substitute teachers made available to schools, the closing of local hospitals, the reductions in child benefits, etc. ${ }^{7}$ For example, according to data from the 
Irish Times, 25,000 students demonstrated on 3 November 2010, 2,000 people marched in an anti-austerity protest in Dublin on 27 November 2011 and, one year later, 10,000 people participated in another. By 2013, anti-austerity protests were rather common across the country, even if most struggled to gather over 5,00o people. Such numbers compare perhaps unfavorably with the major anti-austerity protests that took place in other rescue-package countries such as Italy, Greece, Portugal, and Spain (Zamponi 2012). ${ }^{8}$ But of key importance in Ireland is that many of these protests focusing on economic issues were not organized by the trade union movement and thus were of a kind not seen hitherto. What these protests had in common was a deep-set opposition to the austerity measures resulting from the economic and financial crisis and the perceived sense that the country had now lost its economic sovereignty. The Occupy camps emerged in such a context of protest.

\section{The Occupy Camps}

\section{Emergence}

ODS and Occupy Galway were inspired by the Madrid Indignados movement of May 2011 and by the many American Occupy movements that were well-established by early October 2011. It is perhaps therefore of little surprise that Irish occupiers were inspired by many of the activities, structures, and processes drawn from these international protest-tent campaigns. ODS started as a campaign launched online by a number of people who had been active in various left-leaning organizations including Real Democracy Now and who had been interacting via Facebook and Twitter. ${ }^{9}$ The organizers sent out a call on social media for people to attend a protest rally on October 8 against the financial sector and to attend another one on October 15 in support of the global Occupy movement. Organizers also posted invitations around central Dublin, and potential protesters were told "Yes we camp!" and encouraged to "bring a tent". The protest started as a traditional rally on the afternoon of 8 October with approximately 30 people and grew to 150 people in attendance outside the Central Bank of Ireland's main office on Dame Street, Dublin.

8 'Workers Across Europe Synchronize Protests', The New York Times, 14 November 2012. See also the various contributions in this volume.

9 Interview, Mo..., female, employee, 20+, Dublin, 7 January 2013. 
Approximately $5^{\circ}$ protesters stayed overnight. ${ }^{10}$ They were soon joined by a number of other people and ODS thus got underway. In the following days and weeks, a considerable number of Occupy events were organized such as media workshops, teach-ins, musical and poetic performances, and rallies. By mid-November 2011, the Central Bank announced that it would seek a court order to put an end to ODS, but it continued until 8 March 2012 when the national police force, Garda Síochána, dismantled the camp.

For its part, Occupy Galway was launched on 15 October, one week after ODS. The occupation started with about 50 people and was timed to link up with the international day of solidarity with the global Occupy movement. Since it was to have been a one-day event, protesters in Galway did not necessarily intend to occupy Eyre Square, but a number of them simply stayed on the square when the police did not ask them to move on. ${ }^{11}$ Official requests for the camp's removal only came later when city officials wrote to the occupiers and made public their concerns about health and safety issues.

\section{The Occupiers}

Overall, there were relatively few occasional occupiers and even far fewer permanent occupiers in both Dublin and Galway. ${ }^{12}$ There were at most several dozen occasional occupiers in Dublin and between ten and twenty in Galway. ${ }^{13}$ In the early days, ODS and Occupy Galway brought together an interesting mix of people from all walks of life: students, artists, academics, trade union activists, service workers, local community organizers, and

10 Interview, Th..., male, unemployed, $25^{+}$, Dublin, 7 January 2013. Once the camp was dismantled, gates were installed, thereby limiting the public's use of this space.

11 "Superintendant N. Kelly stated that Occupy Galway were not committing an illegal act and that he was not aware that there was a national position on the occupation of public places" (Minutes of the Galway City Joint Policing Committee, 20 February 2012). The occupation of public space was also a feature of the other Irish camps. For instance, Cork and Waterford occupiers set up their camps along main thoroughfares (respectively at a main intersection and on the quays, both in the heart of the city). By contrast, the Limerick Occupy camp suffered from a 'lack of visibility' since it was located in a by-street, far removed from the city's busy shopping district and away from through-traffic.

12 Occasional occupiers spent neither the night nor the entire day at the camp. They were around only for a few hours a day. Permanent occupiers, in contrast, stayed day and night.

13 Much of the information presented in this section is derived from the interviews we did of Occupy activists and leaders and, in particular, of those that had participated continuously from the very first days in October 2011 to their eventual eviction by the police several months later. 
seasoned political, social and environmental activists. The occupiers were also quite diverse in terms of age, gender, origin, experience of political and social activism, and social and economic profile. The mean age of the occupiers was below 30. Men and women participated in more or less equal numbers. ${ }^{14}$

Although most of the occupiers were Irish, some European backpackers who had been involved in Occupy movements in their own country also visited the camps and stayed for short periods. Some of these occasional occupiers used their visit to show a type of international solidarity with the Irish occupiers, as shown by the posters they drew up in Spanish or in French while there. Although some ODS activists knew each other because of their involvement in Real Democracy Now, ${ }^{15}$ most of the occupiers first met in the camp. Many of the younger occupiers had never before been involved in a protest movement and had no clear agenda ${ }^{16}$ This was also the case in Galway where most of the occupiers did not know each other before joining the movement, ${ }^{17}$ although some of the longer-serving protesters had some experience of activism, notably as part of the Corrib gas protest movement. ${ }^{18}$ One factor that played a key part as the occupations moved from autumn to winter and then to spring is that, students apart, a majority and growing number of the ODS occupiers came from the more disadvantaged sectors of society such as unemployed workers or young homeless people.

Because life in the camp was hard and because many sympathizers had family or professional obligations, the gender, age, and socio-economic mix of the camps soon withered away. In Dublin, for instance, as the camp became a haven for an increasing number of very young and homeless people, it became less 'open' to the general public and more self-fulfilling

14 Irish occupiers are in many ways sociologically similar to what has been identified in other Occupy movements around the world (see Benski et al. 2013: 548-50).

15 Interview, Mo..., female, employee, 20+, Dublin, 8 January 2013. Real Democracy Now is a group formed out of the $15 \mathrm{M}$ movement in Spain. See http://www.realdemocracynowireland. org/.

16 Interview, He..., female, retired, 65+, Dublin, 19 November 2012. By comparison with OWS, the "episode as a whole has become an irresistible magnet for radical academics of the culturaltheory sort; indeed, for them it seems to have been a sort of holy episode, the moment they were waiting for, the putting into practice of their most treasured beliefs" (Frank 2012).

17 Interview, Gil..., male, unemployed, 50+, Galway, 17 November 2012.

18 The Corrib gas project concerned the extraction of a natural gas off the northwest coast of Ireland, in County Mayo. This project was opposed by local residents and activists for environmental and security reasons. Several protesters were jailed following confrontations with the police in 2005 . 
and inward-looking. In such circumstances, we may well ask if the very young and homeless people stayed in the camp because they supported the movement's ideals or rather because they were looking for moral or material support.

Quite a large public was generally well-disposed to the Occupy movement. If they weren't, it wouldn't have lasted as long as it did. That it didn't become a mass, a massive movement is, I think, a case of people saying 'What can I do? I can't go down there, I have a job!'. And, as time went on, it is true that the places did start to attract people who had nothing to do with it. Just people who thought it was a good place to pan-handle [...] You just get professional beggars turning up. This was bound to happen. I don't see this as anything particular to the Occupy movement. [...] All body-politics get infiltrated by parasites. The Occupy movement is nothing special in that case. ${ }^{19}$

By December, we noticed that most of the permanent occupiers were in fact homeless young men. They weren't really interested in the movement. All they really wanted was a place to sleep and to get warm. [...] This led to a lot of problems. ${ }^{20}$

\section{Depictions: The Symbolic Background of Mobilization}

Along with the difficulties in ensuring the camps' social and economic diversity, occupiers found it difficult to develop their mobilization potential. ${ }^{21}$ One reason for this is that it is particularly tricky for vulnerable, underprivileged, or powerless people and groups to 'voice' their concerns or to impose their vision on society especially when their actions are denied political content and/or meaning. When 'marches', 'sit-ins', or 'occupations' do take place, they are often interpreted or depicted in negative terms by the very people, or by the social categories - the political, social, and/ or economic elites - who have the most to lose from the protests. So it is particularly important to understand what the vulnerable, underprivileged, or powerless people seek to gain from their actions, that is, how they understand or give meaning to their actions (Goffman 1967). What may seem irrational to an outside observer may make perfect sense to a protester. In 
other words, looking at the common and dominant ways that the Occupy campaigns were depicted is perhaps not the best way to understand what took place or to assess the political significance of the events. It is perhaps more useful to consider what the occupiers did or said they were doing and thus to look at how they challenged the ways they were commonly portrayed. When individuals try to understand why they are subjected to what they feel to be arbitrary decisions and/or forms of discrimination, their subjective feelings may be enough to put in place mobilization processes (Gamson 1975). As Snow and Benford suggest, "movement organizations and actors are actively engaged in the production and maintenance of meaning for constituents, antagonists, bystanders and observers" (1992: 136). We will now summarize briefly the main ways that the Occupy camps were described before considering the experiences and the representations of the occupiers themselves (Snow 2004).

The camps were portrayed in several ways, the majority of them negative. In the most common depictions, many small businessmen and local politicians scorned and mocked the occupations. The camps were condemned as illegal gatherings and the occupiers decried as irrational radicals, unpatriotic social misfits, and outdated eco-warriors who were carrying out ridiculous actions. ${ }^{22}$ The mainstream media rarely referred to the camps, but in the rare moments that journalists broached the subject, the comments had condescending overtones. One such example is a feature published in the Irish Times:

I stopped by the Occupy Dame Street protest on the way home the other night and what struck me most was how extraordinarily nice the whole thing is. It's so polite and well-behaved that it could almost be some kind of civic amenity laid on by City Hall. ${ }^{23}$

Such commentators were either incapable or unwilling to take the camps seriously. ODS and Occupy Galway were also deemed to be socially destabilizing, illegal, and even illegitimate. Local politicians in Galway were particularly anxious to dismantle the encampment before the start of a major international ocean race in June 2012 so as not to harm the city's international reputation. ${ }^{24}$ In Dublin, local businesses expressed increasing

\footnotetext{
22 Interview, Th..., male, politician, 50+, Limerick, 5 January 2013.

23 Frank McNally, The Irish Times, 15 October 2011.

24 Retrieved 7 November 2013 from http://www.thejournal.ie/unoccupied-gardai-removeprotesters-from-eyre-square-452640-May2012/.
} 
levels of dissatisfaction and annoyance as ODS became a permanent local fixture. ${ }^{25}$ These views were based on the belief that camps were giving the country a bad name at a time when all that really mattered was to secure tourist revenue and to promote Ireland's image as a safe and stable country in the eyes of foreign investors.

A second series of depictions focused on the social and economic determinants of the camps. For some commentators, Irish public authorities' subservience to international capital during the 'Celtic Tiger' years - and the subsequent collapse of the Irish economic miracle as of 2008 - precipitated and ultimately led to the country's very rapid move from a high-growth and high-performing economy to that of an economic basket case represented by its banking, fiscal, and financial crises (Kirby 2010; Kitchin et al. 2012). Ironically, occupiers even received the indirect and unexpected support from one of the country's main business journals. ${ }^{26}$ They were, perhaps surprisingly, seen by such commentators as the unlikely opponents of the destructive forces of international capital and of the unbearable social consequences of neoliberal, free-market economics policies.

A third series of depictions focused on the occupiers' amateurism. A number of commentators alluded to the utopian nature of the camps (McDonald 2012). But criticism was perhaps the more pronounced and damning when it originated specifically from the left of the political spectrum. Here, references to Occupy Galway and ODS camps heralded a 'new dawn' for the working class in Ireland but under the specific leadership and guidance of enlightened and campaign-hardened left-wing political activists. Occupiers were portrayed as political amateurs whose conceptual frameworks were redolent of conspiracy theorists lacking in class understanding. ${ }^{27}$ In many ways, the very small left-wing parties from whom the most negative depictions emerged seemed more interested in scoring political points against

25 Retrieved 7 November 2013 from http://www.thejournal.ie/occupy-dame-street-camp-iskilling-temple-bar-businesses-335948-Jan2012/.

26 "Over the previous two decades, financial market regulation has been pared back to almost observer status. The thinking was that any sort of regulation that hemmed in market forces was unnecessary and bureaucratic. It was an orthodoxy that became a cornerstone of economic policy throughout OECD countries. It obviously hasn't worked. Consequently it would be a mistake to ignore the incipient protests against Wall Street as the vacuous bleatings of professional radicals. It is symptomatic of a much deeper and wider malaise that western government would do well to heed" (Business \& Finance October 2011, Retrieved 5 November 2013 from http:// www.businessandfinance.ie/index.jsp?p=1026\&n=996).

27 Retrieved 7 November 2013 from http://www.communistpartyofireland.ie/sv2011-11/03dame-st-2.html. 
one another, in decrying the occupiers' "false consciousness", and in denying political meanings to the occupiers' actions.

These varied and widespread depictions all rest on the belief that Occupy Galway and ODS did not have any significant political value. The first series of depictions considered them to be no more than public order disturbances. The second viewed them as being economic in origin and that improvements in the country's social and economic conditions would resolve all issues. The third was based on politics, but the occupiers were curiously absent from the analysis in that they were denied a political status and their experiences and representations were not taken either seriously or into consideration. The following section looks at the experiences and representations of the occupiers to see how they themselves framed their actions.

\section{Experiences and Representations}

As noted above, many occupiers criticized the systematic failings of the Irish economic system and wished to show their anger, despair, and frustration at the increasingly widening gap between Celtic Tiger expectations and current economic realities. ${ }^{28}$ Many of them were convinced that the country had been brought to its knees by the collective greed of Irish financiers. ${ }^{29}$ Many occupiers aired their loathing of the greed culture that had spread during the Celtic Tiger years and of the reckless investments of financial institutions which had brought the economy to such depressingly low levels. ${ }^{30}$ They felt that international economic actors including the European Commission, the European Central Bank, and the International Monetary Fund were now playing an invidious role in diminishing the Republic's economic sovereignty and democratic foundation. A number of occupiers also stated that they joined the encampment and stayed on for several weeks because they were deeply troubled by the Irish social and political state of affairs ${ }^{31}$ They felt that they had been betrayed by the abject failure of the political class to protect Irish people's interests and that their own and their children's future offered little more than economic hardship and emigration. ${ }^{32}$ They pointed out that the government-imposed cuts

29 Interview, Ch..., male, unemployed, 25+, Galway, 17 November 2012. 
were unfair, and they stressed that the cuts overwhelmingly targeted the poor and the weak (pensioners, the young, single parents, the unemployed, social welfare recipients, etc.) while those responsible for the deep recession (bankers, speculators, property developers) were not held to task. They vented much of their anger against the Irish political elite that had allowed the economic crisis to develop. For some occupiers, the need to 'kick out the government and the politicians in power' was an instrumental factor that led to their participation in the occupations..$^{33}$ Others stated that they saw the camps as useful insofar as they represented a forum where they could raise the public's awareness about the Irish political elite's responsibility for the crisis. Many of these occupiers also saw the camps as extremely useful from an educational point of view because the camps allowed them to see and to understand the extent of corruption at local and national levels that had led to the economic morass. In Galway, for example, some occupiers indicated that the camp was for them a "wake-up call" ${ }^{34}$ in that it helped them to become active within their community.

Many occupiers felt that conveying their anger and despair in this collective format was therapeutic, as it allowed them to give voice to the frustration that they often found hard to express publicly. Many other occupiers also found personal comfort, solace, and solidarity in the camps. For these people, the camp helped them to break feelings of loneliness, personal failure, guilt, solitude, and/or despair. ${ }^{35}$ Other occupiers felt that the camp allowed them to do something concrete for the country, but many of them despaired at the level of passivity in Ireland.$^{36}$ Some attributed this passivity to the lack of political conscience, to a poor level of political education, or to the ever-present moral dictates of the Catholic Church. ${ }^{37}$ Since this was the first time that many of the younger activists had ever participated in a collective action, they were enthusiastic about learning how to become politically active. ${ }^{3}$ Many of them also pointed out that they learned very quickly how to deal with practical issues such as how to build

33 Interview, Ch..., male, unemployed, 25+, Galway, 17 November 2012.

34 Interview, El..., female, student, 20+, Galway, 17 November 2012.

35 Interview, Fi..., female, student, 20+, Galway, 17 November 2012.

36 In some ways, the public's passivity shows that high levels of anger and frustration do not necessarily lead to mobilization.

37 One occupier also attributed the passivity to the renowned inclement Irish weather (Interview, Fi..., female, student, 20+, Galway, 17 November 2012). Another attributed the passivity to prevailing begrudging attitudes (Interview, Mo..., female, student, 20+, Dublin, 8January 2013). 38 Although the more seasoned activists were often frustrated that the movements were not more militant, many of the younger participants stated that they became politically aware because of their involvement in the cause. These younger participants thus became increasingly 
and to maintain a viable camp when faced with adverse conditions such as bad weather, security issues, or the lack of hygiene. But in essence, learning from others' experiences and raising the public's awareness were for many occupiers the key incentives for their involvement in Occupy. ${ }^{39}$

Occupy Galway and ODS protesters were inspired by the demands, forms, rituals, and models used by Spanish and North American Occupy activists and, as such, put forward rather broad demands:

The issue of demands has been a contentious one, particularly at OWS, although not so much at ODS [...] Elsewhere in the Occupy movement there was a reluctance to make demands, as demands imply acceptance of a system that the movement has set out to undermine or even overthrow. These were broad demands on which everyone could agree, but could not easily be conceded. (Sheehan 2012: 5$)^{40}$

In ODS, Real Democracy Now activists - inspired by the Spanish $15 \mathrm{M}$ movement - framed the movement's original demands but they only really focused on the Irish situation..$^{41}$ The demands - adopted by Occupy Galway one week later - were formulated as follows: (1) the departure of the International Monetary Fund from Ireland; (2) the end to public ownership of private banks' debts; (3) the implementation of what was entitled "real participatory democracy"; and (4) the return to public ownership of Ireland's privatized oil and gas reserves. ${ }^{42}$

Another way Occupy Galway and ODS were inspired by North American activists was by using their strategies, forms, and rituals. For example, Occupy Galway and ODS encampments were manned round-the-clock. In Galway, ten to twelve people on average were present daily, with occupiers staying mainly in blocks of two to three days. Participation rates in Dublin were slightly higher. Both camps lasted for what may be considered a remarkably long period (five months in the case of ODS and seven in

aware that they had a political role to play but that they did not necessarily need to do so via representative democracy or through party politics.

39 Interview, Se..., male, student, 25+, Dublin, 16 February 2013.

40 Helena Sheehan is a US-born, Dublin-based academic, now retired. A former member of the Irish Labour Party, she has been very active in left-wing circles since the 1970s and was one of the early activists involved in ODS. In publishing a personal account of her involvement in ODS, she provides a rich analysis of the conflicting narratives at hand in ODS (leadership, agenda, strategy, etc.).

41 Interview, Mo..., female, employee, 20+, Dublin, 8 January 2013.

42 Retrieved 5 January 2013 from http://www.thejournal.ie/video-occupy-dame-streetprotesters-explain-aims-of-peoples-movement-251277-Oct2011/. 
that of Occupy Galway) considering the very difficult living and security conditions occupiers faced (cold and wet weather, sustained pressure from local authorities and the police, harassment from local residents, passers-by and late-night revelers, etc.). ${ }^{43}$ ODS protesters also organized daily general assemblies and used 'open mics' by passing a microphone from one speaker to the next so that all opinions could be heard and no one could dominate procedures. An ODS activist had also seen the successful use of 'mic-check rituals' (protestors telling their stories in a call-and-response formats) in YouTube videos of Philadelphia protests and thought it would go down well in Dublin as the ultimate democratic way to proceed. So as in many international protest-tent campaigns, Irish occupiers depended on the crucial role of social media in encouraging people to come together in high visibility public places - Eyre Square in central Galway and outside the Central Bank of Ireland in downtown Dublin. ${ }^{44}$ These public places were chosen because protesters could not be evicted or arrested for trespassing and since such spaces "belong to everybody and to nobody at the same time". ${ }^{45}$ For Occupy Galway activists, the camp's central location was also important because they would not run the risk of being part of an "invisible" protest and it would be easier for them to put their views to the general public. As in OWS, the camps' locations and the available material and symbolic resources also helped shaped the emerging relations between the occupiers themselves and with the general public. Much of Occupy Galway's or ODS's material resources such as tents, sleeping bags, or food came from public donations. ${ }^{46}$ Local businesses gave food, members of the public donated money, tradesmen offered their expertise and building material, etc. ${ }^{47}$ These donations helped to sustain the occupiers and allowed them to provide small-scale support services for some homeless people or for the occasional occupiers who were encouraged to stay in the camp for however long they wished. All these initiatives were well supported initially

43 One Occupy Galway activist described herself as a bouncer. Interview, Ao..., female, student, 20+, Galway, 17 November 2012.

44 "We are in Eyre Square because the public owns the square and because the protest is a visual statement". Michael Lyndon, protester of Occupy Galway quoted by Andrews (2011).

45 Interview, Ch..., male, unemployed, 25+, Galway, 17 November 2012.

46 "People have come with blankets and food and words of encouragement, others stay for a while in solidarity. [...] Even people who are opposed to what we do, when we explain what we are about see what we are getting at". Michael Lyndon, protester of Occupy Galway quoted by Andrews (2011).

47 Interview, Mo..., female, employee, 20+, Dublin, 8 January 2013; Interview, Gi..., male, unemployed, 50+, Galway, 17 November 2012. 
but, as we indicated above, in time many locals became far less disposed towards the camps.

Occupy Galway and ODS also resisted the establishment of hierarchical structures. Occupy Galway and ODS preferred fluid processes based on open, democratic objectives. For instance, general assemblies were often held twice daily where all comers could bring up any subject even if it meant that general assemblies often led to "tortuous discussions". ${ }^{8}$ The rituals of participatory democracy, borrowed from OWS in particular, were much welcomed in the early stages of Occupy Galway and ODS, but they soon became fraught with difficulty especially when new occupiers tried to settle in or when practical decisions needed to be made quickly to address immediate problems, most notably in ODS. Two such examples in ODS were the difficulties associated with stopping the theft of laptops, cell phones, and money, or the problems linked to the organization of direct-action initiatives. ODS also facilitated public meetings and debates involving trade unionists, political activists, and the general public. But again in Dublin, perhaps more so than in Galway, the meetings also often led to many increasingly intractable disputes that had more to do with petty concerns than with substantive issues. ${ }^{49}$

Occupy Galway and ODS were, nonetheless, vastly different in some key respects from the many Spanish and North American movements that inspired them. The comfort, solidarity, and strength that many Irish occupiers felt by participating in the camps did not mean that the vast majority of them considered that it was imperative that ODS or Occupy Galway become politically active. Many occupiers found it very difficult to acknowledge that they were engaging in political acts or that they could ever align themselves with a political organization. In fact, most of the occupiers never really framed their claims in radical, ideological terms, as had been the case, for instance, of the Indignados in Spain or in OWS (Castañeda 2012). Although a minority of the occupiers attributed the country's problems to fundamentally unjust and neoliberal economic priorities, the majority stayed away from politics per se. Most simply felt that greed and political expediency were at the root of the problems and that restoring Irish values and sovereignty would be sufficient.

A leading Galway occupier proclaimed often and proudly that "we are not a political group".$^{50}$ In ODS, however, discussions centered far more on 
the movement's political mission than on its identity, at least in the initial stages.

I returned on day two, a Sunday, which was a much quieter day. I participated in a smaller assembly and found it really frustrating. It was about defining what we were. Over and over in the next days, I heard things that made me cringe at the conceptual confusion that seemed to prevail: assertions that this was not a political movement, that it was neither right nor left, that participants were welcome as individuals but had to leave their politics at the door. I tried to be patient, to argue that a person's political philosophy was something integral to his/her being and not something that could be left at the door, aside from the other absurdity of this constant injunction - the fact that we had no door! I invoked a conception of politics that was broader and deeper than party politics. We need to reclaim the polis, I contended. Some took the point, but others continued with the 'no politics' rhetoric regardless (Sheehan 2012: 2)

Occupy Galway and ODS activists were also quite pragmatic. The ODS organized various working groups: a security group, a food group, a media group, and an 'Open University' group. However, although the 'Open University' group organized scores of public lectures, it became a particularly key source of contention. One reason is that, in Dublin in particular, some 'working-class' occupiers felt that 'middle-class' occupiers were far too active in 'intellectual' pursuits such as the 'Open University' but that they were not doing their share of the more mundane tasks such as getting food, building shelters, or dealing with security issues..$^{1}$

In some ways, the following stringent criticism of OWS could be applicable in the case of ODS in the first few weeks but no longer after that since most of the 'intellectuals' or the 'politically active' had been pushed to the margins or simply gave up coming to the camp.

A while later I happened to watch an online video of an Occupy panel discussion held at a bookstore in New York; at some point in the recording, a panellist objected to the way protesters had of saying they were 'speaking for themselves' rather than acknowledging that they were part of a group. Another one of the panellists was moved to utter this riposte: 'What I would note, is that people can only speak for themselves, that 
the self would be under erasure there, in that the self is then held into question, as any poststructuralist thought leading through anarchism would push you towards [...]. I would agree, an individualism that our society has definitely had inscribed upon it and continues to inscribe upon itself, 'I can only speak for myself', the 'only' is operative there, and of course these spaces are being opened up [...].' My heart dropped like a broken elevator. As soon as I heard this long, desperate stream of pseudo-intellectual gibberish, I knew instantly that this thing was doomed. (Frank 2012: 1) 52 $^{2}$

So the discourse in Occupy Galway and ODS was far different from some of the radical viewpoints expressed in OWS in particular (Flank 2011). Although Occupy Galway and ODS protesters decried the state and the scale of inequality in Ireland, radical policy proposals were never high on the agenda. Occupiers in Ireland understood very well that the bank guarantees and the emergency rescue package led to cutbacks in social welfare, in educational support, or in health provision, but they were not necessarily sure how the policy decisions could be overturned nor did they seem willing to offer concrete, alternative political solutions. So in this sense they reacted to events rather than devised and proposed alternatives. They also seemed aware that they were involved in a unique type of protest event for Ireland, but they were reluctant or unsure how to broaden the scope of the protest. ${ }^{53}$ The physical occupation of public space until eviction was the extent of the radical measures taken, although one Dublin occupier considered that the "camp was too inward looking and that it drained away from the movement". ${ }^{54}$

Equally important is that while the consensus approach inspired by OWS was of help in building solidarity in the small and relatively homogeneous Galway group, it was not of much use in the larger and far more diverse ODS. Resistance to formal structures in ODS notably led to a situation whereby cliques soon formed and whereby some of the stronger and more vocal personalities dominated proceedings. For example, tensions in ODS were particularly apparent when some of the camp's 'permanent residents' suggested that only they, as 'real' occupiers, should have a higher status in

\footnotetext{
$5^{2}$ Thomas Frank is the co-founder and was co-editor of the Chicago-based left-wing magazine The Baffler, which focuses on cultural, political, and business issues.

53 "At one assembly I asked: 'Do you want to build a camp or do you want to build a movement?' I believed that a camp obsession, even narcissism, was subverting the attempt to build a movement" (Sheehan 2012: 13).

54 Interview, He..., female, retired, 65+, Dublin, 19 November 2012.
} 
decision-making and only they should be allowed to define, to decide, and to voice demands. ${ }^{55}$ For many of the round-the-clock occupiers, only they had the legitimacy to speak out. This led to constant strife between the 'real' and the 'moral' occupiers in particular and limited the movement's public reach or alliance-building potential. For instance, some guests were not allowed to speak at organized events because of their trade union or political backgrounds, protest marches were abandoned because they had not received 'proper' approval, and general assemblies were set during working hours so that only permanent occupiers could realistically attend. These types of problems of rivalries were rampant and existed very early on within the camps. They often led older and more seasoned activists to become frustrated with the idealism and naivety expressed by these younger activists who wished above all to be apolitical. ${ }^{56}$

Some of those camping became obsessed with the camp and with an inflated image of themselves as the core of this movement. 'I camp therefore I am' I said of them on one occasion, when I was frustrated by the camp narcissism, paraphrasing Descartes to ends he never intended. One habitually referred to himself and others in the camp as 'heroes of the revolution' [...] I believed that a camp obsession, even narcissism, was subverting the attempt to build a movement. (Sheehan 2012: 7)

In Dublin, some of the initial organizers also felt that the newer, younger, and more permanent occupiers failed to appreciate the history of the left and of the trade union movement in Ireland (as in the United States, as Smith demonstrates in this volume). "It was as if all protest started in October 2011." ${ }^{27}$ For many of the 'moral' activists, the 'real' occupiers were doomed to fail because they refused to frame the movement in class-based terminology and to seek the support of more seasoned and radical social and political groupings. In Dublin in particular, the newer (and younger) activists were extremely wary of being infiltrated by radical political organizations, and they were also extremely distrustful of and disillusioned with the trade

55 One ODS participant attributes this division as based on class. The 'permanent' occupiers came mainly from the more disadvantaged parts of Dublin and many of them were young homeless people, whereas the occasional or 'moral' occupiers were principally middle-class, rather well educated, and often in stable jobs. In Dublin, this also led to some minor disputes between students and some of the less economically privileged occupiers. Interview, Mo..., female, employee, 20+, Dublin, 8 January 2013.

56 Interview, Ge..., male, employee, 50+, Dublin, 5 January 2013.

57 Interview, He..., female, retired, 65+, Dublin, 19 November 2012. 
union movement. This 'no politics' approach was fundamentally different to what had emerged in OWS. In New York, the "episode as a whole has become an irresistible magnet for radical academics of the cultural-theory sort; indeed, for them it seems to have been a sort of holy episode, the moment they were waiting for, the putting into practice of their most treasured beliefs" (Frank 2012). By comparison, occupiers in ODS and in Occupy Galway had different views:

[We wanted] to create a movement with no affiliation to political parties and to resist entryism on the part of any existing political formations [...] There was an obsession with a ban on political and trade union banners and literature. There was fear of any organisation bringing its own agenda into this movement. [...] From the beginning, in fact before the occupation actually started, much of the discussion was driven by hostility to the Socialist Workers' Party. (Sheehan 2012: 3)

In Galway, we took a pragmatic stance. We let the various parties or organizations that gravitated around Occupy access to the camp but they couldn't use it as a platform to get recruits for themselves because we were not linked to anyone and we didn't share the Socialist Workers' Party's political views..$^{8}$

Some of the more seasoned - but ultimately shunned - activists in Dublin considered that this 'no politics' stance was naive and ultimately destructive. ${ }^{59}$ For them, ODS ran the risk of withering away if broad social and political alliances could not be established. This is part of what Lipsky (1968) suggests when stating that the powerless in society have many ways of expressing themselves politically but that their political existence depends very much on the help provided by third parties. But as time passed, occupiers in both Occupy Galway and ODS were particularly adamant that they would not enter into alliances, as also happened in other Occupy campaigns around the world (Uitermark and Nicholls 2012). They took this stance despite evidence that allies in the trade union movement or even within some of the parties of the 'left' may well have helped to diffuse and to support their cause. The occupiers also took the 'no-alliance' approach even though many of them were well aware that this stance would limit their chances of diffusing their viewpoints and that this could cut off public 
support. Theirs was a conscious and tactical decision. Occupiers believed that by refusing to enter into alliances, they would be preserved from accusations of being politically inclined and thus were ensuring the purity of their cause.

But collaboration and communication between the various Occupy camps around the country was also remarkably poor. Only a very small minority of occupiers travelled to other camps to see what was taking place or to discuss common issues. An even smaller number took part in Occupy's National Assembly. This lack of communication and incapacity to share information and experiences certainly hindered the camps' ability to organize collective actions and campaigns, to refine their goals and strategies, or to set up a national platform to voice their claims. ${ }^{60}$ But, yet again, many of the occupiers had limited interest in national issues and preferred to concentrate on improving their own lot in life.

In short, internal characteristics and tactical decisions limited Occupy Galway and ODS's capacity to widen their campaigns, to secure positive public opinion and sympathy, and to create spaces that were open and inclusive of people most harmed by the effects of the recessions such as the 'new poor' and the homeless. It could well be argued that the increasing presence of homeless people weakened Occupy Galway and ODS's mobilization potential, since many middle-class members (with relevant social capital) became increasingly reluctant to take part. As the Occupy Galway and ODS became less and less diverse in terms of their social and economic make-up, the camps soon became ends in themselves, generating an exclusionary group dynamic and contradicting the slogan "We are the $99 \%$ " that made it difficult to build a wider movement. ${ }^{61}$ This allowed the Occupy Galway and ODS to lose their way in the mist of internal conflicts. Ultimately, the camps wore themselves down by dealing with a host of relatively minor daily issues, leaving little time for collective action. In retrospect, it could be argued that the camps were the sole expression of the movement. Rooted to a location, they 'traveled' with difficulty. Attempts to widen the movement were fiercely resisted and became practically impossible, not only because of the movement's internal characteristics and tensions (and lack of resources) but also because the occupation of a

6o In February 2012, during a National Assembly of the Occupy movement, some participants wondered: "What happened to the other Occupies? Are they worn out, no funds, divided, disbanded, or just too busy?" (Minutes of Occupy National Assembly, Rossport, 4 February 2012). The question highlights the remarkably poor level of communication between the campaigns, as well as the perceived lack of impact and visibility at the local, regional, or national levels. 61 On the lack of credibility of the slogan, see Smith's chapter in this volume. 
public space for an undetermined period of time became the participants' sole symbolic expression of protest. But did they really want anything else?

In this chapter we focused on the Occupy Galway and ODS camps. We pointed to a number of key issues and questions occupiers faced: how to overturn common depictions of them; how to generate mass support and participation; how to transform narrow interests into symbols that concerned Irish society as a whole; and how to be seen as champions of the public good? All proved difficult to bring about. Although the occupiers gradually slotted into the daily routine of the local community where they garnered some support, when the camps became 'eyesores', local support turned sharply against them. ${ }^{62}$ As for public authorities and the police, they never considered the protesters to be sufficiently disruptive or threatening that they had to be removed urgently. They simply waited for the initiatives to run their course before serving orders on the few remaining occupiers to dismantle the camps and evicting them. Only at this point did a few minor public disorder incidents arise. ${ }^{63}$

Aside from the euphoric first few weeks, the camps existed in a social and political vacuum and proved to be especially unattractive and uninviting to the victims of the economic crisis and, more widely, to the general public. One key reason for Occupy Galway and ODS's difficulty in spreading their message is that the activists refused to take a political stance and to enter into alliances similar to their Spanish colleagues' position but with different outcomes (see chapter 5 in this volume).

Many of the younger protesters - many of whom came from the more disadvantaged parts of Dublin or Galway - were also radically opposed to the idea of building alliances with the trade union movement or with left-wing parties as they felt this would co-op the movement and distort its original raison-d'être. This led to ongoing conflicts between many of these first-time younger protesters and many older, middle-class, and more seasoned activists who believed that Occupy Galway and ODS could not evolve without the help of such key allies. In addition, occupiers were determined not to make specific claims or to deal with public authorities. Their preferred strategy was to snub the 'enemy' and to refuse to acknowledge

62 Irish Independent, 23 January 2012.

63 Interview, El..., female, student, 20+, Galway, 17 November 2012; Interview, Mo..., female, employee, 20+, Dublin, 8 January 2013. 
the 'system's' legitimacy so as to preserve the camps' independence and purity. Although the practical benefits of such an approach are questionable (Smith and Glidden 2012), the strategy is understandable in theory at least. But by refusing to engage with public authorities or even with potentially important allies, Occupy Galway and ODS protesters consciously and willingly reduced their capacity to have a wide-ranging political or social impact or even to make the camps more attractive to their focus group, the victims of the Celtic Tiger's collapse. As a result, the slogan "We are the 99\%" proved to be particularly ill-adapted to Occupy Galway and, even more so, to ODS. Although Occupy Galway and ODS activists expressed the view that the camps were open to one and all, ODS especially did little to make many of these victims feel welcome. Pressure was put on newcomers to become 'permanent residents' or to leave aside their political feelings. These examples point to a movement that was guided by people who were, in some cases, rather inflexible and intolerant. Limited by their strategic choices and by the small number of the occupiers who had relevant organizational experience and knowledge, Occupy Galway and ODS never truly managed to widen their appeal. ${ }^{64}$

But it is perhaps unreasonable to focus solely on some of these negative elements of the Occupy Galway and ODS. Despite some of the camps' difficulties as described above, there were a number of key positive outcomes. Many young and previously politically apathetic people had come to take part for the first time in a collective action. An ODS activist has pointed out that these young and 'naïve' protesters were frustrated at not knowing why their world was crumbling around them. ${ }^{65}$ They were fed up with the 'lies' and sickened by the depressing state of affairs. They wanted to 'do something' but they could not express clearly exactly what they wanted. These protesters were taking a plunge into the unknown. Although they had no specific claims aside from the four described above, they were adamant that the movement should have no leaders and they really wanted to stay together in the camps for as long as they could. As one protester stated, all he really wanted was to stay put "until they forced us to move". ${ }^{66}$ These occupiers thereby seized the occasion to develop personally. Even though public authorities, the mainstream media, and the general public largely ignored the camps and their occupiers, many of the first-time protesters stated that they benefited immensely from the experience. Some of the

64 Interview, Mo..., female, employee, 20+, Dublin, 8 January 2013.

65 Interview, Da..., male, independent filmmaker, 35+, Dublin, 19 February 2013.

66 Interview, Ch..., male, unemployed, 25+, Galway, 17 November 2012. 
more seasoned and politically engaged activists took another view. Some found it particularly frustrating to see their younger colleagues shun the well-established traditions of protest in favor of what they viewed to be a narcissistic and utopian exercise. For these seasoned and politically engaged activists, Occupy Galway and ODS activists never appeared able - or really willing - to project themselves beyond the camps, with the result that the camps became the sole symbolic expression of protest. One such activist who left the Dublin camp in protest in December considered that this was an 'ironic' stance for a movement that claimed to be largely inclusive - "We are the $99 \% "$ - and that pretended to be the voice of all the victims of the crisis. ${ }^{67}$ Nonetheless, many of the younger and longer-standing occupiers felt that participating in the camps was the most important thing they had ever done in their lives and pointed out the educational or formative experience of Occupy: "The main aim of occupy is to educate and empower people to change the system. We must be patient with the 'people' and with each other and keep an eye on the big picture to avoid bickering. ${ }^{n 68}$

In short, a key element of ODS and Occupy Galway relates to the activists' frames of experience and of representations and thus to ODS and Occupy Galway's political significance. Weak public support, few alliances, weak resources, and occupiers' subsequent feelings of isolation or of despair may have led them to feel that they had 'nothing to lose' by taking action and by remaining in the camps as long as they could. Perhaps because Dublin and Galway occupiers did not put forward specific claims or because they did not want to have hierarchical structures, they did not conform to expected means of actions. But this was not necessarily a sign of weakness or an indication that their efforts were futile. The longest-serving occupiers in Dublin and in particular Galway told us that Occupy ignited a flame in them as it allowed them to become aware of a host of key social and economic issues. Occupy also showed them how hard it is to initiate collective action. The occupiers felt they built a collective cause, however limited in scope and in impact. They condemned the social and economic problems they faced and they also denounced the socially disseminated representations and institutional practices. In doing so, they expressed and justified their actions in political terms and actions. But also of paramount importance is that Occupy allowed these politically apathetic people to become politically active in the defence of a number of causes in the final stages of the camps 
and in the months that followed the camps' dismantlement. ${ }^{69}$ These are positive elements, irrespective of the total number of people who were involved in Occupy from October 2011 to May 2012. Occupy Ireland shows, therefore, the importance of listening to what the occupiers were saying, of considering why they acted in the ways they did, and of taking account of what they gained from the experience.

\section{Bibliography}

Andrews Kernan. 2011. 'Occupy Galway vows to stay as long as it takes', Galway Advertiser, 10 October.

Benski Tova et al. 2013. 'From the Streets and Squares to Social Movement Studies: What Have We Learned?', Current Sociology, 61 (4): 541-561.

Castañeda Ernesto. 2012. 'The Indignados of Spain: A Precedent to Occupy Wall Street', Social Movement Studies, 11 (3-4): 309-319.

Donovan Doval, Murphy Anton. 2013. The Fall of the Celtic Tiger: Ireland and the Euro Debt Crisis. Oxford: Oxford University Press.

Flank Lenny (ed.). 2011. Voices from the 99 Percent: An Oral History of the Occupy Wall Street Movement. St Petersburg, Florida: Red and Black Publishers.

Frank Thomas. 2012. 'To the Precinct Station: How theory met practice... and drove it absolutely crazy', The Baffler, 21. Retrieved 5 January 2013 from http://www.thebaffler.com/past/ to_the_precinct_station.

Gamson William. 1975. The Strategy of Social Protest. Homewood: Dorsey.

Goffman Erving. 1967. Interaction Ritual: Essays in Face to Face Behavior. New Brunswick: Transaction Publishers.

Kirby Peadar. 2010. Celtic Tiger in Collapse: Explaining the Weaknesses of the Irish Model. Basingstoke: Palgrave Macmillan.

Kitchin Rob et al. 2012. 'Placing Neoliberalism: The Rise and Fall of Ireland's Celtic Tiger', Environment and Planning A, 44 (6): 1302-1326.

Lipsky Michael. 1968. 'Protest as a Political Resource', American Political Science Review, 62 (4): 1144-1158.

McDonald Henry. 2012. 'The Irish squatters taking on empty homes and a bankrupt system', The Guardian, 3 January.

Pickerill Jenny, Krinsky John. 2012. 'Why Does Occupy Matter?', Social Movement Studies, 11 (3-4): 279-287.

Sheehan Helena. 2012. 'Occupying Dublin: Considerations at the Crossroads', Irish Left Review. Retrieved 4 January 2013 from http://www.irishleftreview.org/2012/o1/19/ occupying-dublin-considerations-crossroads/.

Smith Jackie, Glidden Bob. 2012. 'Occupy Pittsburgh and the Challenges of Participatory Democracy', Social Movement Studies, 11 (3-4): 288-294.

69 See, for example, http://www.youtube.com/watch?v=ul2esP2Ug88, retrieved 9 December 2013; http://www.flickr.com/photos/67918286@No5/745414689o/in/photostream/, retrieved 3 December 2013 . 
Snow David. 2004. 'Framing Processes, Ideology, and Discursive Fields', in Snow D. et al. (eds.), Blackwell Companion to Social Movements. Oxford: Blackwell, 380-412.

Snow David, Benford Robert. 1992. 'Master Frames and Cycles of Protest', in Morris A., Mueller C. (eds.), Frontiers in Social Movement Theory. New Haven: Yale University Press, 133-155.

Uitermark Justus, Nicholls Walter. 2012. 'How Local Networks Shape a Global Movement: Comparing Occupy in Amsterdam and Los Angeles', Social Movement Studies, 11 (3-4): 295-301.

Zamponi Lorenzo. 2012. 'Why Don't Italians Occupy? Hypothesis on a Failed Mobilization', Social Movement Studies, 11 (3-4): 416-426. 



\title{
11 The Occupy Movement in France
}

\author{
Why Protests Have Not Taken Off \\ Didier Chabanet and Arnaud Lacheret
}

Many observers were surprised that the Occupy Movement attracted very little support in France, while in other neighboring countries, notably Spain, street protests were huge and numerous. The cry of Stéphane Hessel - in his book Indignez-vous! ('Time for outrage!') - is said to have been a remarkable bestseller ${ }^{1}$ but had hardly any knock-on effects. Although this observation is accurate, we feel the need to add several comments that mitigate its scope. First, the Occupy movement, as strong as it may be in certain regions of the world, is a phenomenon which remains globally limited. On the European scale, most countries have not witnessed any significant mobilization, as the Italian case shows (cf. Zamponi 2012). From this angle, France does not stand out as an exception and follows the general trend. The astonishment is based largely on the idea that France is traditionally a country with a high level of social and political contention. This belief seems to be borne out by statistical analysis, in any case over the period of 1990-1995, in which France was the European country that experienced the most protest events, far more than Germany or Spain (Nam 2007: 108). At the same time, this capacity for mobilization was not linear and often led to extremely intensive peaks, such as in the 1995 strikes in the public sector or the 2006 protest against the reform of the labor law (Contrat de première embauche, CPE) (Lindvall 2011). It is possible, therefore, that mobilization has undergone a momentary slump or is following a temporality of its own, without this prefiguring its future development. One may add that the density of civil society in France, especially its associative and trade union sectors (Béroud et al. 2008), is notably weak (Balme and Chabanet 2008: 48), which may partly explain the somewhat eruptive and unpredictable nature of social protest. Thus, the situation is at once complex and relatively paradoxical, combining a high level of social and political agitation with a decline in the structures which were for a long time the main channel of expression of popular discontent (Fillieule 1997).

In France, the first Occupy demonstrations took place at the end of May 2011, in the capital but also in the provinces, particularly in Lyon, Marseille, 
Poitiers, Toulouse, and in several towns in the southwest of the country. In all, twenty or so towns were involved. Settlements were rare or of short duration, with the exception of Bayonne where they lasted for six weeks. The gatherings involved a few hundred people, except in Paris where two demonstrations brought together between 2,000 and 3,000 protestors. On 15 October 2011, the Occupy demonstrations organized simultaneously in several dozen countries made it possible to measure the level of mobilization on a world scale. In Paris and in France's main provincial towns, no gathering of more than 3,000 people was recorded, while in several dozen towns abroad, processions of over 5,000 people were frequent. In Madrid (500,000), Barcelona (300,000), Rome (100,000), Valencia (50,000), Lisbon $(80,000)$, Santiago de Chile $(80,000)$, New York $(40,000)$, Berlin $(10,000)$, Frankfurt $(10,000)$, Brussels $(7,000)$, or even Toronto $(5,000)$, the crowd was even much larger. ${ }^{2}$ Without being non-existent, the mobilization in France did not really take off. Thus, in the spring of 2012, several processions of a few dozen people coming from different provincial towns converged on the heart of the capital after marching through deprived inner districts of the Paris suburbs, able to gather only a few hundred demonstrators at its peak on 21 April 2012.

To understand the inability of Occupy to mobilize large numbers of people in France, we set out a series of reflections that relate to the social, political, and economic circumstances of the country. We begin by examining the effects of the political calendar, particularly in the specific context of the presidential election campaign of 2012. We then show that access to the labor market and the employment situation in general remain less catastrophic than in many European countries where the Occupy movement or the Indignados have grown. In France, the diploma continues to protect a large proportion of young people from the most aggravated forms of exclusion and precarity. But the relative protection of some is associated with a deterioration for others, especially in districts where the most marginalized populations are concentrated. One of the main failures of Occupy was precisely not having been able to rally to its cause those who, in the suburbs, were the most socially exposed. Unable to spread throughout French society and remaining isolated, the mobilization attempt was vulnerable and completely exposed to police repression. In the final section of the chapter, we seek to understand - on the basis of a survey carried out amongst participants of Occupy Lyon - why the latter did not succeed in arousing a broad mobilization impetus. 
From a methodological standpoint, our approach is resolutely qualitative. Given that our study commenced after the end of the mobilization, in the fall of 2012, we initially tried to contact activists. Our research led us to identify a local radio host and trained sociologist who had organized several broadcasts with Occupy and had himself taken part sporadically in mobilizations. We questioned him at length at the outset, and he put us in touch with other militants, each of whom in turn provided us with one or several names. This snowball sampling strategy allowed us to carry out seven in-depth telephone interviews and one face-to-face conversation at the home of one Occupy participant, each interview lasting about an hour. We also watched several dozen hours of online broadcasts made by the local media (radio, TV) devoted to the Occupy movement in Lyon and which was an invaluable source of information. ${ }^{3}$ Lastly, we analyzed the 'archives' of Occupy in Lyon, made up of fifty or so typescript pages in a pouch. These archives are the only written traces of the movement on itself that we have been able to track down. They outline its internal organization, actions, programme, and political claims. ${ }^{4}$

\section{The Ballot Box Rather Than the Street?}

The difficulty that Occupy experienced in attracting large numbers of people in France cannot be explained by the absence of grievances and discontent. Generally speaking, the French are particularly worried about their future, especially young people under the age of 25 . In addition, French citizens are among the most critical towards globalization, capitalism, and the market (Cahuc and Carcillo 2012: 21-30).

The mobilization of Occupy must first be understood in the light of recent struggles, which resulted in scathing failures and which may have discouraged some potential militants. Thus, in France, the two most recent large protest movements - against the reform of universities in 2007 and against reform of the retirement system in 2010 - were marked by the intransigence of the government, which did not yield to demonstrators. It is possible that this intrasigence prompted most of those who struggled against liberal globalization to withdraw, at least for the time being, to

3 See for instance http://www.mediascitoyens.org/Retrouver-la-capacite-d-agir-3.html; http://www.radiopluriel.fr/spip/Les-indignes-rassemblements-a-Lyon.html.

4 Analysis of the situation in France since 2011 and testimonies by the activists themselves can be found at: http://paris.reelledemocratie.net/taxonomy/term/186. 
the private sphere, in accordance with Hirschman's theory (1982) about shifting involvements.

Some observers later pointed out that the Occupy mobilization began to emerge on the international and European scene in the middle of 2011, at a time when the main thrust of French political activity had turned to the presidential election of May 2012. This latter event harnessed a large part of the social discontent. With some representatives of left-wing political parties being ideologically very close to Occupy, the very real possibility of a left-wing victory in the elections may have convinced some French citizens to opt for change via the ballot box rather than a strategy based on the streets. It is true that, during the presidential campaign, the visibility of the Left Front and the rhetoric of certain Greens or that of certain leaders of the Socialist Party on the necessity of 'deglobalization' gave the impression that the ideas of Occupy might be translated into policy if the left won the election. One could argue that an open structure of political opportunities, and in particular the presence of influential allies supporting the mobilization and even picking up some of its demands, may have lessened its mobilizing capacity (Tarrow 1994: 85-89). ${ }^{5}$ One would find here the symptoms of a strongly politicized society, even amongst the youth (Bréchon 1998), whose expectations would still broadly find an institutional political expression. During the same period, the context was very different in Spain and in Greece, where governments were totally discredited in the eyes of the public (Wieviorka 2011). Certain analysts were expecting a surge of indignation in France in the event that the new ruling government would not succeed in finding solutions to the social problems facing the country. One must, however, note that the grave crisis of confidence and credibility that the left-wing government has been going through, and its incapacity to reverse the unemployment trend, did not benefit Occupy, which prompts us to search for other types of explanation.

\section{Diplomas, the 'Open Sesame' of the Labor Market}

The political context correlates closely with the economic crisis that France is going through. Without playing down the importance of the problems being faced, the country has been relatively protected and has suffered a

5 One of the main weakness of the POS argument is that, for some, a favorable POS enhanced mobilization and social movement development while for others, it was the reverse, like for the Indignados in France. For a discussion of the approach, see Fillieule and Mathieu 2009. 
less severe crisis than many others, especially those in southern Europe (see chapter 2 in this volume). If poverty, social exclusion, and unemployment are on the increase in France, the situation is 'less worse' than in Spain, Portugal, or Greece. In 2011, the share of people at risk of poverty after social transfers was 14 per cent in France, 21.8 per cent in Spain, 18 per cent in Portugal, and 21.4 per cent in Greece (Eurostat 2012). The French welfare state is able to soften the adverse effects of social inequalities better than in most other countries. The French universalist system (Esping-Andersen 1990) fulfills its role of buffer and regulator of conflicts, which is the main function of social protection in periods of recession and mass unemployment (Piven and Cloward 1990). Applied to the whole population, the explanation can be convincing, but it is weaker with regard to those under the age of 25 . Certainly, the youth unemployment level in France may be two times lower than in Spain or Greece, but it remains significantly higher than the French national average. ${ }^{6}$ Above all, the main social assistance provisions in force in France remain inaccessible - in fact if not by law - to youths under the age of 25 who are therefore particularly vulnerable socially (Chabanet and Guigni 2013).

But more than the level of unemployment as such, it is the structure of, and access to, the labor market that stand out. Although diplomas represent a kind of 'open sesame' against precarity and still guarantee that one will eventually be able to obtain stable employment, most recruitment of young people today takes the form of an insecure contract or one of limited duration (Conseil d'orientation pour l'emploi 2011). The French labor market operates according to a dichotomous rationale that protects the most educated wage earners at the expense of those who leave the education system early and are often untrained.

A survey carried out in 2010 amongst several thousand young people who completed their education in 2007 showed that 92 per cent of those holding a doctorate were employed, stable or otherwise, just as did 88 per cent of those who had graduated from an engineering or commerce institute, and 80 per cent of those with an undergraduate degree (bachelor). On the other hand, only 55 per cent of those with a college diploma and 48 per cent of young people leaving the school system without a diploma were employed (Cereq 2011). The capacity of the French labor market to absorb young qualified people, as opposed to Greece or Spain for example, would be one of the reasons for Occupy's failure to mobilize large numbers of youths.

6 In December 2012, the unemployment rate of 15-24 year-olds in the active population exceeded 24 per cent, compared to 10 per cent for the total population (Insee 2012). 
Because the rise in unemployment and the phenomenon of exclusion do not affect French youth as a whole to the same degree, the families of the French middle and upper classes have always, for good or ill, the feeling that their children will escape the worst. Despite the relative worsening of the economic crisis, the most socially sheltered classes, also often the most politically active, no doubt still cling to individual strategies, focusing for example on the academic achievement of their offspring.

\section{The Fragmentation of Territories: When Indignation is Selective}

"Youth is only a word" (Bourdieu 1978:143-154). In relation to social vulnerability factors, its heterogeneity is indeed glaring. The inequalities that cut across it allow us to outline the sociological profile of Occupy and, hence, one of the characteristics of the French case. What is noticeable, in fact, is the inability of Occupy to open itself up to the most marginalized populations, who are moreover at the heart of the economic, social, and political domination that activists denounce.

Admist widespread indifference, riots are in fact growing in France, giving an almost banal status to events which were hitherto relatively exceptional and thereby demonstrating the irresolvable relegation of a segment of French youth, literally shunned by society (Lapeyronnie 2008). The anger and despair upon which these insurgencies thrive refer back to several issues that are at the center of Occupy's discourse. In these "exile districts" (Dubet and Lapeyronnie 1992), the level of youth unemployment is often the same as for young Greeks or Spaniards. The issues of wealth distribution, access to jobs, dignity, respect one for another, or equality of opportunity which are emphasized by a multitude of civil society actors in deprived suburbs did not lead to any convergence with Occupy even though the latter hold fundamentally the same aspirations.

This fragmentation of French youth is not new. Already in 2006, demonstrations against the First Recruitment Contract $(\mathrm{CPE})^{7}$ had revealed a split between, on the one hand, young people concerned about their future but generally educated and on the verge of entering the labor market and, on

7 Restricted to those under 25 years of age, the measure involved establishing a period of 'consolidation' of two years during which the employer could sack his or her young employee without notice nor justification and with a payoff reduced to a pittance. The idea, promoted by the government and the French employers' organization, involved de-regulating recruitment conditions for young people so as to encourage their entry into the labor market and thus, paradoxically, speed up their obtaining stable employment. 
the other hand, a segment significantly more excluded. The first became heavily mobilized, while the second did not. The weakness of Occupy stems from the same phenomenon and reflects its isolation in the space of social movements (Mathieu 2012). The paradox is all the more remarkable that the phenomena of class downgrading and urban violence are much more present in France than in most other European countries, with the exception of Great Britain (Chabanet 2014). Increasingly, mobilizations play out in segmented areas, which mutually ignore each other. In Paris, Occupy initially mobilized downtown and took over the main public places, with few links or contacts with the suburban areas where social problems are often concentrated. This pattern is the consequence of a long process that began at the end of the 1970s and progressively saw the 'urban question' replace the 'social question' (Viard 1994). In this sense, the difficulties of Occupy in France cannot be simply attributed to an economy that is less affected by the crisis than that of other countries.

\section{Between Isolation and Repression}

A series of different but converging phenomena contributed to marginalize Occupy politically. From the outset, the mobilization was built out of a radical critique of representative democracy. Refusing in particular the principle of the delegation of power, the movement sought to exist by itself with neither leader nor spokesperson. Acting in this way may have reinforced Occupy detachment from a certain number of activists networks - trade unionists in particular - which in other countries were able to make the link between various forms of opposition to austerity policies implemented by governments (see chapter 9 in this volume). This isolation was accentuated by the fact that French political life traditionally reserves an overriding place to political parties and, to a lesser degree, to trade union organizations, that is to say to actors whose role is institutionally recognized, who operate internally according to relatively hierarchical rules, and who tend to monopolize the social and political debate (Mathieu 2012). Lastly, given the importance the presidential election has in French national political life, the bulk of the forces on the left - especially the Left Front, which includes the Left Party and the Communist Party - preferred to focus on the preparation of this decisive event rather than actively support diverse groups from Occupy, themselves very attached to their autonomy of action.

Struggling to mobilize, Occupy did not win over the press either. One can clearly see in this situation a consequence of the dynamic specific to the 
French political field, largely built around a few predominant organizations. Whatever the reasons, the main French media, whether newspapers or television, have given wider coverage to Occupy demonstrations abroad than in France. Some could criticize the timidity of a journalistic environment traditionally suspected of indulgence with regard to the economic or political elites (Gamson and Wolfsfeld 1993) - accessories of the system that Occupy denounces. In any case, Occupy was the subject of residual and relatively critical coverage in the traditional media, while more alternative channels (independent media, local radios, social networks, etc.) gave them more coverage and were often favorable.

The low visibility of Occupy in France, both as a force for mobilization and as an issue in the public sphere, has consequences for the policing to which it is subject. We know that the conditions of interaction between the police and a protest movement are one of the constituent dimensions of the latter, more or less facilitating its existence and development (Della Porta and Fillieule 2004). In France, repression was all the more easy given that it passed - as the mobilization itself did - almost unnoticed. The very modest size of the Occupy marches as well as the weak interest shown by the mainstream media allowed the police, almost as numerous as the demonstrators themselves, to disperse the gatherings quite quickly and to prevent highly symbolic public places such as the Bastille in Paris from being occupied for any substantial period of time (Mille Babords 2011). Police repression can be a resource for a social movement when it is broadly visible and can then be the subject of public denunciation. In France, none of these two conditions were met, so much so that nearly everywhere across the territory, gatherings were almost systematically dispersed, some demonstrators arrested and prosecuted on the spot, making lengthy occupation of public places extremely difficult. No other civil society actor intervened in solidarity.

While in Spain, the daily magnitude of demonstrations led the police to tolerate the occupation of the Puerta del Sol square in Madrid for one month and half (from 15 May to the end of June 2011), in France this phenomenon never happened. The media coverage of France's less visible mobilizations was far from homogeneous, but the way in which France Info - the main continuous information radio in the country - covered, on 21 May 2011, the evacuation of the Place de la Bastille in Paris clearly shows that, without open hostility, the principal French media insisted, more or less insidiously, on the weakness of the movement and its immaturity:

It was after 9 p.m. that the CRS [riot police] went into action, on the Place de la Bastille which this afternoon had the airs of the Puerta del Sol. 
The demonstrators had set up tents, some hoping to spend the night on the spot, like the Madrid indignados. But the law enforcement services dismantled them, accompanied by boos from the crowd. A rapid evacuation, with tear gas, after a day spent dreaming of direct democracy and another world. This Sunday, the French 'Occupy movement', after ten days of confidential meetings, finally succeeded in bringing together a good thousand people. ${ }^{8}$

Even if it is based on protest of a moral nature whose political content remains somewhat broad and blurred, Occupy has in different countries formulated a number of issues which give it a relative specificity: employment and housing in Spain, austerity measures imposed by the Troika in Greece (see chapter 6 in this volume), the denunciation of the fall in purchasing power in Israel (see chapter 4 in this volume), or the banking system in the United States. In France, Occupy rapidly abandoned the Bastille to concentrate on the business district of La Défense, the Parisian symbol of financial capital, borrowing thereafter from Occupy Wall Street the slogan "We are the $99 \%$ ". At the same time, a link was forged with associations like Droit au logement (DAL, 'Right to Housing') or ATTAC, which thereafter took part in some Occupy demonstrations. But Occupy was not capable of getting back to concrete and clear-cut slogans having meaning in the public arena. This critical analysis was, moreover, made internally by Occupy activists themselves:

From the outset, the movement rejected parties and trade unions. But when the task of elaborating a platform of proposals came up, it was not able to do more than generalities and declarations of intent. [...] However efficient this self-organisation might be in its practices, it cannot conceal forever the absence of a clear and debatable political project. ${ }^{9}$

It is difficult to highlight a particular element that explains the inability of the Occupy movement to grow and develop in France. Rather, it is the combination of economic and political factors but also the fragmentation of French social movements that nipped the mobilization in the bud. In this context, two segments of the population, active in other countries, were

8 http://www.franceinfo.fr/france-societe-2011-05-29-l-evacuation-expeditive-desindignes-de-la-bastille-539963-9-12.html.

9 Independent and ordinary collective for a radical self-transformation of society: https:// www.nantes.indymedia.org/articles/23974. 
only very weakly engaged in France: on the one hand, young educated and graduates; on the other hand, youths facing social insecurity, especially in the suburbs, whose despair and resentment find little political expression. For different reasons that are beyond the scope of this chapter, these two segments of the French population did not take to the streets, leaving the issue of insecurity, unemployment, and rising inequality in the hands of institutional actors.

\section{A Case Study: Occupy in Lyon}

The genealogy of Occupy Lyon is very enlightening and can help us to make sense of its difficulties to develop..$^{10}$ In Lyon, as in Paris or even Bayonne, the first steps were taken by young Spaniards, often students in training in France. It is they who, echoing the Spanish mobilization, were the first to gather in the spring of 2011 to discuss their desire to see the emergence of a similar movement in France. Even if the mobilization subsequently spread to other nationalities, it was born out of a feeling of international solidarity, which while evolving remained one of its main features. In Lyon, hardcore activists took part several times a week, sometimes almost continuously, in meetings and demonstrations. This group was made up of thirty or so people, often involved in humanitarian action such as defending the rights of refugees, immigrants, or Roms. Most of them were sensitive to 'major causes' such as protection of the environment, the struggle against world poverty, or support for the Palestinians. Overall, their profile doubtless did not allow them to fit in with the local militant network, a factor that often contributes to the success of a mobilization (Uitermark and Nicholls 2012).

From the outset, several elements stand out. On the one hand, this group was made up of people coming from different backgrounds whose unity was problematic and not built around a project and clearly identified objectives. For example, the mobilization was not established as a reaction to a government decision, which could have provided political cohesion. It was rather born out of the willingness to participate in an event which began to emerge abroad and which met a strong desire for change in the militants in Lyon. In the absence of a clear and unambiguous slogan, people from quite diverse walks of life found themselves a common ethic which led them to

10 The investigation was carried out after the mobilization phase. The remarks which follow are therefore the fruit of an a posteriori analysis, based mainly on processing information collected through interviews and on documents supplied by Occupy activists themselves. 
refuse to tolerate "a world led by a caste of the rich"11 in which the interests of a very small number of the privileged override those of the vast majority.

The values and expectations that these militants harbor undoubtedly have a strong political dimension, but they do not find their expression through traditional forms of participation. Thus their rhetoric did not make any reference to a particular party or trade union commitment. More broadly, for them, the right/left divide, which continues to dominate the bulk of institutional political life in France, appears almost devoid of any meaning.

The world such as it is today, it is the whole political class that has built it, or let it go unrestrained for ages. Frankly, why trust them? For me, they all failed. We are now faced with immense, gigantic problems which we are going to have to resolve on our own otherwise we will not make it. That is the Occupy movement. For me, it is also a way of saying in the face of all those in power 'that's enough! Stop the crap, it's us the ordinary people, the citizens, who decide..12

Among protestors, the specter of political opinions is extremely broad, ranging from the centre-right to social catholicism, anarchism, libertarianism, or the extreme-left - which in itself reflects a high level of heterogeneity - without any of these currents being really structuring. The influence of Trotskyist networks, often linked with youth movements, remained very limited. In the absence of strong support, the mobilization never exceeded more than a few thousand individuals, on an intermittent basis. With its weaknesses, it demonstrates the changes affecting contentious action today. The sociology of Occupy activists fits perfectly with what scholars have been arguing over the last twenty years concerning the renewal of contemporary militant practices (Ion 1997; Perrineau 1994). On average, Occupy is made up of a relatively educated public. Human sciences students are quite wellrepresented in these mobilizations, which may be explained both by this group's tendency towards social criticism and a greater difficulty than students from other academic background in finding stable employment. On the whole, the activists we interviewed thought that the majority of participants in Occupy were under the age of 30 and often had unstable

11 Interview with Patrice, presenter at Radio Pluriel, occasional militant, and sympathetic to Occupy (8 January 2013).

12 Interview with Marie, project leader and community activist, highly committed in Occupy Lyon. 
employment or little jobs. Cultivated without being politicized, ${ }^{13}$ they were both very open to the world, expressing ideas and strong convictions, but only rarely adhered to a militant organization. In the slogans and rhetoric, their discontent shows up in two versions: one takes the form of general disgruntlement faced with the injustices of the world and sticks to a logic of denunciation; the other goes a bit further and calls for "leaving the system". The movement's archives thus never raise the question of class struggle or social exploitation. Instead, they describe a form of organization gasping for breath, making of each individual a slave. The world is thus said to be at "a total dead end, simultaneously at the economic, financial and monetary, social, media, political, and demographic levels". ${ }^{14}$

Very quickly, it appeared obvious that we had one sole and same objective: that of changing a world that is not like us, because it does not care about our basic needs.

A world in crisis deserted by the future.

A world where our natural habitat is in great peril, putting even our survival in danger.

A world of false images where our creativity is perpetually corrupted and diverted.

A world where our daily life is encapsulated in advertising.

A world where the only links that bind us are marked by the seal of greed, of lust, of profit.

"Real democracy now', like a call to wake up from the bad dream into which we have plunged. ${ }^{15}$

For the Occupy activists, it is above all a question of "resisting" and putting human beings at the heart of all circumstances in life, to struggle against ambient dehumanization. The expected change will then be the result of the awareness amongst individuals, in other words the voluntarism of everyone.

Generally, Occupy is wary of classical forms of participation, which are considered inefficient, constraining, and/or corrupt. More or less explicitly, it aspires to a balance between individual opinions and the organizational requirements of a collective movement. The desire to not sacrifice the first to the second is a constant concern, which results in the importance given

13 Interview with Régis, teacher, activist in Occupy Lyon (8 March 2013).

14 Unsigned, undated archive entitled text read at the beginning of the AG of 9 June: 'Our cry of hope'.

15 Ibid. 
to everyone's opinion and in the search for consensus during meetings. Such an objective requires the total involvement of those who keep the movement going day after day and resulted sometimes in exhaustion tinged with discouragement when it became clear that the mobilization was not taking off. If Occupy demands no other affiliation than that of "citizen movements that rise up throughout the world", ${ }^{16}$ it may be considered the successor of all the struggles which, in France as in most developed societies, call for the emancipation and free will of individuals or citizens, rejecting by the same token the traditional forms of commitment and representative democracy (Inglehart 1977): "We advocate democracy that is direct, participative, selfmanaged, and anti-hierarchical." ${ }^{\prime 17}$

In the spring and summer of 2011, older people, often better integrated in the labor market and coming mostly from the communist left, took part in organized demonstrations and contributed somewhat to get the movement out of its lethargy. Occupy tried hard to attract social categories more exposed to greater deprivation or class downgrading by contacting associations established in difficult districts, but to no avail. After a few months, having failed to reach a positive momentum, the mobilization of Occupy ultimately ran out. In Lyon, the demonstrations did not exceed a few hundred people except for a gathering of about 5,000 supporters that took place on 16 October $2011 .^{18}$

Finally, the group was weakened by internal tensions. A major split emerged between two tendencies. On one side were those who favored the occupation of public places, in particular campsites, and who openly drew inspiration from Occupy Wall Street. On the other side were those who concentrated even more on the construction of Internet exchange and communication networks, putting the accent on the dissemination of ideas and theoretical reflection. The first sometimes prided themselves on being 'real' militants on the grounds that they were more exposed and took more risks by facing up to the police, while the second expressed their satisfaction of contributing to the cognitive enhancement of the mobilization through the use of social networks. These two approaches moreover come within different timeframes (also present in the Spanish Indignados, see chapter 5 in this volume), some seeking to provoke through action a short-term response from public authorities so as to get the movement established

16 Undated and unsigned archives, entitled 'Who manages the debt of our lives. Moods and analyses'.

17 Undated, unsigned archive entitled 'A societal project?'

18 Until now the largest Occupy meeting in France. 
in the public sphere and on the political agenda; the others regarding the battle of ideas as the most important, and engaging in discussions to make possible, in the long term, the emergence of a better and less unjust world.

$$
* * *
$$

In France, Occupy's inability to grow has multiple causes arising from economic (the impact of the crisis was less severe than in other countries and academically qualified youths have been broadly spared the most acute forms of unemployment and insecurity) and political factors (the prospects of the left coming to power and the existence of a bid from the extreme-left, which served to snuff out discontent). Other explanatory factors are more worrisome and point to growing fractures within French society. Autonomous and isolated at the same time, the mobilization was unable to prevail. Against this background, the case of Occupy Lyon suggests that this weakness is also explained in part by the sociological features of Occupy, which comprises a group at once heterogeneous and divided, lacking local roots.

\section{Bibliography}

Balme Richard, Chabanet Didier. 2008. European Governance and Democracy. Lanham, Md: Rowman \& Littlefield.

Béroud Sophie et al. 2008. La lutte continue? Les conflits du travail dans la France contemporaine. Broissieux: Le Croquant.

Bourdieu Pierre. 1978. Questions de sociologie. Paris: Éditions de Minuit.

Bréchon Pierre. 1998. 'Les jeunes et la politique en Europe et en France', Agora - Débats / Jeunesses, 12: 11-22.

Cahuc Pierre, Carcillo Stéphane. 2012. 'Les Juges et l'économie: une défiance française', Paris: Institut Montaigne, Retrieved May 252014 from http://www.institutmontaigne.org/medias/ documents/etude_juges_et_economie.pdf.

Calvo Kerman. 2013. 'Fighting for a voice: the Spanish 15M movement', in Flesher Fominaya Cristina, Cox Laurence (eds.), Understanding European Movements. New Social Movements, Global Justice Struggles, Anti-Austerity Protest. London: Routledge, 236-253.

Cereq (Centre d'études et de recherches sur les qualifications). 2011. Le diplôme, un atout gagnant pour les jeunes face à la crise. Premiers résultats de l'enquête 2010 auprès de la génération 2007. Paris: Ministère de l'Éducation nationale, de la Jeunesse et de la Vie associative, du ministère du Travail de l'Emploi et de la Santé.

Chabanet Didier. 2014. 'Between Violence and Demand for Participation: Urban Riots in Europe', in Chabanet Didier, Royall Frédéric (eds.), From Silence to Protest. International Perspectives on Weakly Resourced Groups. Aldershot: Ashgate.

Chabanet Didier, Giugni Marco. 2013. 'Patterns of Change in Youth Unemployment Regimes: France and Switzerland compared', International Journal of Social Welfare, 22: 310-318. 
Conseil d'orientation pour l'emploi. 2011. Diagnostic sur l'emploi des jeunes. Paris: La documentation française.

Della Porta Donatella, Fillieule Olivier. 2004. 'Policing Social Protest', in Snow A. David et al. (eds.), The Blackwell Companion to Social Movements. Malden and Oxford: Blackwell, 217-241.

Esping-Andersen Gøsta. 1990. The Three Worlds of Welfare Capitalism. Princeton: Princeton University Press.

Eurostat. 2012. 'At risk of poverty or social exclusion in the EU 27', Newsrelease 171, 3 December. Retrieved May 252014 from http://epp.eurostat.ec.europa.eu/cache/ITY_PUBLIC/3-03122012AP/EN/3-03122012-AP-EN.PDF.

Fillieule Olivier. 1997. Stratégies de la rue. Les manifestations en France. Paris: Presses de Sciences Po.

Fillieule Olivier and Mathieu Lilian 2009. 'Structure des opportunités politiques', in Fillieule Olivier et al. (eds.), Dictionnaire des mouvements sociaux, Paris: SciencesPo. Les Presses, 530-540.

Gamson William, Wolfsfeld Gadi. 1993. 'Movements and Media as Interacting Systems', Annals of the American Academy of Political and Social Science, 528:114-125.

Hessel Stéphane. 2011. Time for Outrage. Indignez-vous! New York: Hachette.

Hirschman Albert. 1982. Shifting involvements. Private interest and public action. Princeton: Princeton University Press.

Inglehart Ronald. 1977. The Silent Revolution. Princeton: Princeton University Press.

Insee (Institut National de la Statistique et des Études Économiques). 2015. 'Le taux de chômage diminue de 0,1 point au premier trimestre'. Retrieved 26 June 2015 from http://www.insee. $\mathrm{fr} / \mathrm{fr} /$ themes/info-rapide.asp?id=14

Ion Jacques. 1997. La fin des militants? Paris: Éditions de l'Atelier.

Lapeyronnie Didier. 2008. Ghetto urbain. Ségrégation, violence, pauvreté en France aujourd'hui. Paris: Robert Laffont.

Lindvall Johannes. 2011. 'The Political Foundations of Trust and Distrust: Reforms and Protests in France', West European Politics, 34 (2): 296-316.

Magmaweb. 2011. 'Les mouvements des “indignés": potentialités, contradictions et perspectives', 17 June. Retrieved 25 May 2014 from http://www.magmaweb.fr/spip/spip.php?article5oo.

Mathieu Lilian. 2012. L'espace des mouvements sociaux. Bellecombe-en-Bauges: Éditions du Croquant.

Mille Babords. 2011. 'Informations sur la répression violente du mouvement des Indignés', 22 September. Retrieved May 252014 from http://www.millebabords.org/spip.php?article18437.

Nam Taheyun. 2007. 'Rough Days in Democracies: Comparing Protests in Democracies', European Journal of Political Research, 46 (1): 97-120.

Perrineau Pascal (eds). 1994. L'engagement politique. Déclin ou mutation? Paris: Presses de la Fondation nationale des sciences politiques.

Piven France F., Cloward Richard. 1990. Regulating the Poor: The Functions of Public Welfare. Random House: New York.

Tarrow Sidney. 1994. Power in Movement. Cambridge: Cambridge University Press.

Uitermark Justus, Nicholls Walter. 2012. 'How local Networks Shape a Global Movement:Comparing Occupy in Amsterdam and Los Angeles', Social Movement Studies, 11 (3-4): 295-301.

Viard Jean. 1994. La société d'archipel. Paris: Éditions de l'Aube.

Wieviorka Michel. 2011. 'Lindignation virtuelle: une exception française?', Libération, 25 August.

Zamponi Lorenzo. 2012. 'Why don't Italians Occupy? Hypotheses on a failed Mobilisation', Social Movement Studies, 11 (3-4): 416-426. 



\title{
12 Conclusion
}

\author{
Place-Based Movements and Macro Transformations \\ Pascale Dufour, Héloïse Nez and Marcos Ancelovici
}

The chapters in this volume have detailed a great variety of situations. As far as the empirical translation of the crisis into concrete manifestations of discontent is concerned, we could insist on the fact that each society and its protests are unique. Instead, we seek general trends and patterns. How, then, should we move from empirical details to future research paths worth exploring? We propose two basic elements. First, we stress the influence of capitalism on protests in conditions of austerity. Is there a clear link between the current crisis of capitalism and the emergence of new families of protest? To what extent are there material foundations to such protests? How has the economic crisis concretely affected different struggles? What do we need to do analytically to develop this line of inquiry? Second, the contemporary crisis of representative democracy has its counterpart in the space of protest, as some contributors of this volume have shown. How have profound changes in the relationship between, on the one hand, individuals and groups and, on the other hand, formal politics structured today's protest movements?

\section{Bringing Capitalism Back In: Not a Mechanical Effect but an Important Factor}

As mentioned in our introduction to this volume, many things converged to link the financial crisis that began in 2008 with the resurgence of protest. First, temporality: most of the protests studied in this book occurred in the wake of the economic collapse of 2008. Second, discourse: the protesters denounced recent transformations in capitalist economies, including both the process of financialization and the deepening of inequalities. Activists in North America and Europe have struggled against the stagnation or decline of low and medium wages, sharp increases in unemployment - in Spain, for example, the unemployment rate was about 20 per cent when the Indignados emerged - and the extravagant explosion of high incomes in the financial sector. The protests they organized contributed to a repolarization of the debate around globalization and the distribution of wealth. For 30 
years, sociologists had announced the end of social classes and of their role as the main organizing principle of identities, interests, and collective action (Pakulski and Waters 1996). Yet, the post-2010 mobilizations call for a reconsideration of the centrality of class and capitalism in social movement studies (cf. Hetland and Goodwin 2013; Della Porta 2015). Such a reconsideration should not entail sweeping and generalizing claims, for it is clear that the current global financial crisis has not produced the same effects everywhere, even if poverty and inequality did increase in all the countries under scrutiny in this book.

To address the role of capitalism, we follow two lines of inquiry. First, in order to claim that the protests have had a material basis, we need to distinguish the victims of the crisis from the people who actually mobilized and ask: Who was hurt by the crisis and how? And who were the protestors sociologically speaking? Second, we propose different paths to research the dynamics and diversity of capitalism as well as the dynamics and diversity of protests.

\section{Searching for the Material Basis of Protest: Complex Inequality Regimes}

In chapter 1, Ross showed that one of the most striking differences between the US and Europe concerns the question of who has been hurt by the crisis. In the US, it was much less a middle-class affair than it was in Europe, and this was especially true for the youth in Europe, who faced a level of unemployment never reached before. Although young educated adults were at the core of North American Occupy movements, the absence of work prospects, including for the most educated segment, has been much more a European than a North American problem. For example, in 2011, the youth unemployment rate in Greece and Spain was around 45 per cent! It is also clear that those most hurt by the crisis are not always the ones who protest (see Rüdig and Karyotis 2014). Here, we need to distinguish between those actively involved in the protests and those who support them, sometimes in massive numbers, as in Israel, Greece, and Spain. In chapter 4, Perugorría, Shalev, and Tejerina convincingly show that protesters enjoyed broader support in Israel than in Spain, but not because of economic factors. In Israel, protest was a widespread middle-class affair in which other ideological divisions were minimized for the sake of future generations. In Spain, the left-right cleavage was more important, with those actively supporting the protests coming mainly from the left side of the political spectrum. 
It is clear from this book that there are substantial sociological differences between activists depending on the location of protest. The 'material bases' of mobilization are not the same everywhere. One possible path for future research is to explore the articulation between class and generations. Rosenhek and Shalev (2013) point out that beyond the factor of downward social mobility - which lies at the heart of conflicts in Spain, Greece, and Israel - there is also the labor market exclusion and bleak prospects that youths face. This context was illustrated, for example, by the Occupy slogan 'Searching for a future' and two slogans of the Spanish group 'Juventud sin Futuro' (Youth Without Future), 'You won't have a house of your own in your fucking life!' (jNo tendrás casa en la puta vida!) and 'Without a house, without a job, without a pension, without fear' (Sin casa, sin curro, sin pensión, sin miedo). In order to test such claims, we need to avoid selecting on the dependent variable and also include 'negative' cases, that is, cases where there was little or no mobilization. For example, in chapter 11, Chabanet and Lacheret contend that the lack of resonance of Occupy's discourse and the de facto exclusion of marginalized populations - such as immigrant youths living in poor suburbs - from the movement were a central factor accounting for the weak mobilization in France.

Another dimension worth investigating, from a political economy perspective, is the increasing role of socioeconomic inequalities in mobilization. The mobilizing potential of perceived and experienced inequalities varies across countries and over time. In the United States, some studies have shown that the level of acceptance of inequalities is higher than in Northern and Continental Europe, because Americans believe more in the possibility of upward social mobility even though the country actually has a lower level of social mobility than France (Dubet 2011). The literature also frequently discusses the middle-class decline that accompanies dramatic increases in inequalities. How do such macro-structural patterns interact with a trend toward the individualization of inequality, and how does that affect potential mobilizations?

Furthermore, although the Occupy slogan "We are the 99\%" contributed to bringing income inequality back into the public debate, it also fostered a rather simplistic representation of contemporary inequality and domination (Ancelovici 2012). In particular, it avoided the internal differentiation of the $99 \%$ (Juris et al. 2013). In chapter 8 , Smith argues that Occupy participants in the United States were less equipped than global justice activists elsewhere to help diffuse and take over mobilization in a diversity of contexts, especially among the poorest, and were less able to consider the cumulative effects of class, race, and gender issues. Given the 
widespread recognition that class intersects with ethnicity and gender, discussions of inequality need to move beyond one-dimensional and linear understandings of stratification and look at how intersectionality conditions contemporary mobilizations and protests. In this respect, the concept of complex inequality regime, put forward by scholars such as Acker (2006) or Dubet (2011), could turn out to be a useful analytical tool.

To sum up, contemporary anti-austerity protests suggest that we need to pay more attention to socioeconomic factors. We should not, however, insert them in a 'simple' class-against-class narrative; we need to take into account multiple dimensions and sources of domination. Moreover, the material bases of mobilization do not necessarily reflect existing socioeconomic conditions. They are also shaped by institutional and discursive factors that can play an important role in determining interests and the categories of people who will take to the streets. As Kousis argues in chapter 6, these material bases are connected to, and articulated by, particular organizations like trade unions. And as Nez shows in chapter 5 , they derive their meaning partly from the space and historical narratives in which they are inscribed. The constructed character of the material bases of mobilization suggests that the latter could vary cross-nationally, depending on particular varieties of capitalism and welfare regime.

\section{Varieties of Capitalism and Varieties of Protest}

The main argument of the varieties of capitalism (VOC) approach is that the global political economy does not create uniform domestic capitalist economies. There is no convergence of national models around a set of universal best practices. Instead, diverse national institutions lead to different ways of producing goods and services, and to particular configurations of the labor market (Hall and Soskice 2001; Hancké et al. 2007). From the VOC perspective, we can hypothesize that distinct institutional contexts generate distinct forms of contentious politics (Ancelovici 2002: 455; Bair and Palpacuer 2012). In other words, varieties of capitalism could imply varieties of protest.

This volume does not propose a clear-cut answer to the question of whether there is a correlation between certain types of capitalism and certain types of protest. Much more research needs to be done before reaching such a conclusion. Furthermore, the literature on varieties of capitalism has not demonstrated yet that national institutions have led to significantly different ways of dealing with the 2008 global financial crisis. As Heyes, Lewis, and Clark show: 
While the specific content of policies differs between countries, efforts to reduce workers' rights are currently occurring across all varieties of capitalism, thus calling into question the prediction of VOC analysis that responses to 'exogenous shocks' will differ between varieties in fundamental respects. (2012: 16)

These authors also show that major changes in the balance of power between unions and employers have occurred almost everywhere and that the mobilization capacities of unions have declined since the 199os. In spite of different national institutions, all advanced economies have experienced the development of the financial sector at the expense of the productive one. Therefore, some forms of convergence seem to be taking place, and it does not seem possible to establish significant correlations between the ideal-typical varieties of capitalism identified by Hall and Soskice (2011) that is, either liberal (USA, UK, Ireland, Canada, Australia, New Zealand) or coordinated (Germany, Austria, France, etc. $)^{1}$ - and types of protest. Moreover, within a single country, the level of protest can vary dramatically over time independently of the socioeconomic context.

Several paths for future research can nonetheless be derived from the chapters in this volume. The contrast between Israel and other cases is striking in this respect. It is clear, from Perugorría, Shalev, and Tejerina's chapter, that the type of capitalism developed in Israel over the last two decades has favored the emergence of mass protest. For the first time since World War II, educated youths have lower expectations of well-being than their parents had. This development can be traced to the political choices of successive governments in sectors like housing or education. Here state intervention - or more precisely, state retrenchment from earlier commitments - has affected both the scope and nature of the protesters' grievances.

In Greece, the economic crisis was much more severe than in Israel. The elimination of many social policies pushed hundreds of thousands of Greeks into poverty and precariousness and undermined the very existence of national collective solidarity. The welfare regime in place has progressively ceased to offer reasonable protection to low-paid workers, unemployed people, and poor students. The particular combination of a given variety of capitalism and welfare regime is likely to determine who is most negatively affected and how. In France, those most in need are the ones outside the

1 Other authors have complexified Hall and Soskice's typology and introduced other varieties. For example, Schmidt (2002) talks about three types of capitalism whereas Amable (2003) talks about five types. 
labor market for long periods of time and who rely on social assistance for survival. However, the economic crisis, if it is any consolation, did not make them more worse off than they already were, and this social category has not really taken to the streets so far. Those more likely to engage in protests are the people who are employed and relatively well protected by institutional arrangements (Giraud and Lechevalier 2012). Following this logic, it seems reasonable to consider some recent mobilizations as the result of changes in the employment regime and its underlying institutional arrangements.

In the introduction to this volume, we chose to narrow our focus to a comparison of 'anti-austerity' protests defined as contentious collective actions opposing austerity policies (cuts in education, housing, health care, pensions, government jobs, and services, etc.) implemented by governments under pressure from financial markets and/or supranational institutions in connection with deficit and debt problems (Walton and Ragin 1990: 882). The brief discussion above indicates that not only will the degree of austerity vary across countries, so will the particular way in which austerity is experienced as well as the meaning of anti-austerity protests. Put differently, the political significance and impact of austerity policies partly derive from the institutional context in which they are inscribed.

\section{Back to Democracy: From Representative Democracy to 'Do-It- Yourself' Politics?}

In chapter 3, Kriesi's contribution exposes the complex links between street politics and partisan changes in a context of austerity. He argues that in the US, the main changes have occurred at the level of party politics, in particular because of the growing influence of the Tea Party, while in Greece and Spain, protests translate into a growing distrust of socialist parties, a decrease of participation in elections, and demands for profound changes in the system of representation. Nonetheless, the victory of Syriza in Greece in the legislative election of 25 January 2015 and the success of Podemos in Spain in the European election of 25 May 2014, the Andalusian parliamentary election of 22 March 2015, the 13 other regional parliamentary elections of 24 May 2015, and the national legislative election of 20 December 2015, show that discontent has found an expression in party politics in southern European countries as well. ${ }^{2}$ These electoral results directly

2 In the 25January 2015 legislative election, Syriza received 36.3 per cent of the vote and 149 out of 300 seats. Short of an absolute majority, it then formed a coalition government. In the 25 May 
challenge bipartism in Spain. In the 2014 European elections, the PP and the PSOE each lost 2.5 million votes. The collapse of bipartism is even more pronounced in regional elections. Although the PP and the PSOE often kept leading positions, they have now been forced to strike deals and make alliances with other smaller parties like Podemos and Cuidadanos. They did not manage to obtain an absolute majority in any single region while they had won 8 regions out of 13 in 2011. So far, however, the most severe downfall has taken place at the municipal level, where the PP and the PSOE not only lost the lead but were even removed from power in several cities. The most noticeable and symbolic ones, in this respect, were the victories of 'popular unity' candidacies in the two largest cities of Spain: Barcelona and Madrid. The 2015 national legislative election has confirmed the end of bipartism in Spain: the PP and the PSOE, far from achieving an absolute majority, have each lost more than 5 million votes compared to the previous 2011 results, while Podemos has increased by 4 millions the votes it obtained since the 2014 European elections.

For Oikonomakis and Roos in chapter 9, the strongest shared element of recent protests is the fight for 'real democracy', largely inspired by left libertarian and anarchist currents and characterized by self-representation, direct participation, and leaderless activism. From their standpoint, this search for 'real democracy' questions the participation in the formal system of representative democracy, which is seen as less and less able to mediate the interests and claims of the population. Such a critique of representative democracy is not new. Already in the 1960 s and 1970s, many social movements advocated participatory democracy and put forward what some authors called an 'anti-politics' stance (see for example Berger 1979; Maeckelbergh 2011). More recently, in the mid-1990s, the Zapatistas in Mexico celebrated and practiced horizontal and decentralized grassroots modes of local government (Baschet 2014). We find similar discourses and practices in the global justice movement (Maeckelbergh 2012) and in the neighborhood assemblies that emerged in the wake of the economic crisis of 2001 in Argentina (Sitrin 2012).

2014 European elections, Podemos won 8 per cent of the vote and 5 out of 54 seats allocated to Spain in the European Parliament. In the 22 March 2015 Andalusian parliamentary elections, Podemos obtained 14.8 per cent of the vote and 15 out of 109 seats. In the 24 May 2015 regional elections, the results of Podemos varied between 7.99 per cent in Extremadure and 20.51 per cent in Aragón. Finally, in the 2015 national legislative election, Podemos reached 20.7 per cent of the vote and gained 69 out of 350 seats, becoming the third national political party in Spain, after the PSOE (22 per cent) and the PP (28.7 per cent). 
Some authors contend that contemporary anti-austerity protests are directly and structurally related to "a perceived situation of political disempowerment and opacity in the democratic process (...): people realized that representative institutions were no longer serving the public good, but the interest of a few else, generally, business and economic elites" (Cini and Drapalova 2014:5). For these authors, the denunciation of collusion between economic and political elites by Spanish activists and their search for a 'real democracy' can be read as a direct consequence of this 'institutional corruption'. But the crisis of representative democracy does not mechanically translate into protests and new movements. The emergence and possibility of mobilizations for a 'real democracy' are not only related to economic structures and democratic 'deficits' but also to cultural evolutions endogenous to social movements. For example, in the 1990s Lichterman (1996) analyzed the development of a new style of activism in the US that he called 'personal politics'. More concerned with changes inside social movements and organizations, this style of activism refers to a kind of 'do-it-yourself politics' (Dufour, Bherer and Rothmayr, 2015).

Such research, which is more sensitive to endogenous factors, also suggests that structural changes are not enough for protest to take place. The 'negative' cases of Ireland and France in this volume clearly show that additional factors must be present, as many social movement scholars have demonstrated, for anti-austerity protests in the vein of Occupy to emerge. In chapter 10, Desbos and Royall argue that in Ireland some dimensions of Occupy, such as the refusal to build alliances with other organizations (unions, political parties) despite a low level of participation, limited the potential for the development of a wider movement. In chapter 11, Chabanet and Lacheret contend that in France there were political opportunities, but the segmentation of the space of protest and the relegation of unemployed youth in relatively isolated poor suburbs did not create a favorable context for mobilization.

We began this volume by proposing to problematize contemporary protests rather than assume that synchronicity necessarily entailed that a new 'wave of protest', as defined by Koopmans (2004), was taking place. In chapter 6 , Kousis answered this question by considering mid-term campaigns (two years) in Greece and their expression in different cities and showing that place (as a location of struggles) played a crucial role. Place not only defines a socio-political context but can also imply space for experimentation. Thus, in chapter 10, Desbos and Royall explained how in Ireland, Occupy activities developed as experiments for a fringe of young activists who had not planned a long-term strategy or campaign. Similarly, 
in chapter 7 , Ancelovici treated the occupation as a socio-political and material space. He analyzed how Occupy Montreal activists constantly improvized and gradually redefined their preferences over horizontalism and the general assembly as they addressed problems related to the specific tasks in which they were involved in the camp. In chapter 9, Oikonomakis and Roos focused on the intersection of global diffusion patterns and local characteristics, and proposed the concept of 'resonance' to understand both local potentialities and outside stimulation. It follows that contemporary protests have both a global and a very local dimension. Finally, in chapter 8 , Smith situated Occupy movements in the same cycle of protest as the global justice movement, underlining the distinctive modes of organizing and activism of the two movements.

All in all, we can tentatively conclude that a new family of protest has emerged, related to macro-structural and institutional transformations, such as the erosion of trade union power and political parties, the development of a powerful financial elite, and rising inequalities. These protests can be distinguished from others on the basis of particular discourses and practices stressing horizontalism and 'do-it-yourself politics' as well as the way in which they are inscribed in local places and networks. This family of protest opposes austerity, but does so in way that differs from traditional labor movements and the global justice movement. It is thus a good instance of bounded innovation, at the crossroads of past struggles and transnational diffusion.

\section{Bibliography}

Amable Bruno. 2003. The Diversity of Modern Capitalism. Oxford, UK: Oxford University Press. Ancelovici Marcos. 2002. 'Organizing against Globalization: The Case of ATTAC in France', Politics \& Society $30(3): 427-63$.

-. 2012. 'Le mouvement Occupy et la question des inégalités: ce que le slogan "Nous sommes les 99\%" dit et ne dit pas', in Dupuis-Déri Francis (ed.). Par-dessus le marché! Réflexions critiques sur le capitalisme. Montreal: Écosociété, 15-48.

Acker Joan. 2006. 'Inequality Regimes: Gender, Class, and Race in Organizations', Gender \& Society 20 (4): 441-64.

Bair Jennifer, Palpacuer Florence. 2012. 'From Varieties of Capitalism to Varieties of Activism: the Anti-sweatshop movement in Comparative perspective', Institutions program Working Series: INST2012-09, Working Paper, Institutions Program, Institute of Behavioural Science, University of Colorado at Boulder.

Baschet Jérôme. 2014. Adieux au capitalisme. Autonomie, société du bien vivre et multiplicité des mondes. Paris, La Découverte.

Berger Suzanne. 1979. 'Politics and Antipolitics in Western Europe in the Seventies', Daedalus $108(1): 27-50$. 
Cini Lorenzo, Drapalova Eliska. 2014. 'Protests Out of the Economic Crisis. The Movimento 5 Stelle in Italy and 15M in Spain: Two Instances of a New Politics?'. Conference 'Alternative Futures and Popular Protests', Manchester, 2014.

Della Porta Donatella. 2015. Social Movements in Times of Austerity: Bringing Capitalism Back in Protest Analysis. London: Polity.

Dubet François. 2011. 'Régimes d'inégalité et injustices sociales', SociologieS. Retrieved 28 May 2014 from http://sociologies.revues.org/3643.

Dufour Pascale, Bherer Laurence, Rothmayr Christine. 2015. 'Faire la politique soi-même. Le cas des mobilisations contre les gaz de schiste au Québec', Revue canadienne de science politique 48 (1): 125-146.

Giraud Olivier, Lechevalier Arnaud. 2012. 'L'évolution des modèles allemand et français d'emploi depuis quinze ans: des segmentations différenciées' in Dupré Michèle et al. (eds.), Trajectoires des modèles nationaux. État, démocratie et travail en France et en Allemagne. Bruxelles, Bern, Berlin, Francfort/Main, New York, Oxford, Vienne: Ed Peter Lang, 291-312.

Hall Peter, Soskice, David (eds.). 2001. Varieties of Capitalism: The Institutional Foundations of Comparative Advantage. Oxford: Oxford University Press.

Hancké, Bob, Rhodes, Martin, Thatcher, Mark. 2007. Beyond Varieties of Capitalism. Conflict, Contradictions, and Complementarities in the European Economy. Oxford: Oxford University Press.

Hetland Gabriel, Goodwin Jeff. 2013. 'The Strange Disappearance of Capitalism from Social Movement Studies', in Colin Barker C. et al. (eds.), Marxism and Social Movements, Leiden/ Boston: Brill, 83-102.

Heyes Jason, Lewis Paul, Clark Ian. 2012. 'Varieties of Capitalism in Crisis? The Consequences of the "Great Recession" for Employment and Social Protections and Comparative Institutional Analysis'. Retrieved 5 May 2014 from: http://ilera2012.wharton.upenn.edu/RefereedPapers/ HeyesJason\%2oPaulLewis\%2oIanClark.pdf.

Juris Jeffrey et al., 2013. 'Negotiating power and Difference within the 99\%', Social Movement Studies, 11 (3-4): 434-440.

Koopmans Ruud. 2004. 'Protest in Time and Space: The Evolution of waves of Contention', in Snow David A. et al. (eds.), The Blackwell Companion to Social Movements. Oxford: Blackwell Publishing, 20-46.

Lichterman Paul. 1996. The Search for Political Community. American Activists Reinventing Commitment. Cambridge: Cambridge University P\}ress.

Maeckelbergh Marianne. 2011. 'The Road to Democracy: The Political Legacy of "1968”, International Review of Social History, 56 (2): 301-32.

-. 2012. 'Horizontal Democracy Now: From Alterglobalization to Occupation', Interface: $a$ journal for and about social movements, 4 (1): 207-34.

Pakulski Jan, Waters Malcom. 1996. The Death of Class. London: Sage.

Rosenhek Zeev, Shalev Michael. 2014. 'The Political economy of Israel's “social justice” protests: a class and generational analysis', Contemporary Social Science, 9 (1): 31-48.

Rüdig Wolfgang, Karyotis Georgios. 2014. 'Who Protests in Greece? Mass Opposition to Austerity', British Journal of Political Science, 44 (4): 487-513.

Schmidt Vivien A. 2002. The Future of European Capitalism. New York: Oxford University Press.

Sitrin Marina A. 2012. Everyday Revolutions: Horizontalism and Autonomy in Argentina. New York: Zed Books.

Walton John K., Ragin Charles. 1990. "Global and National Sources of Political protest: Third World responses to the Debt Crisis”, American Sociological Review, 55: 876-89o. 


\section{List of Authors}

Marcos Ancelovici is Associate Professor of Sociology and holds the Canada Research Chair in the Sociology of Social Conflicts at the Université du Québec à Montréal (UQAM). He works on social movements, contentious politics, and the sociology of Pierre Bourdieu, and is currently studying housing struggles and anti-austerity protests in Spain.

Didier Chabanet is Senior Lecturer at IDRAC Lyon and Sciences Po (CEVIPOF). He is also Research Associate at the École Normale Supérieure de Lyon (ENS-LSH). He works in the fields of collective action, European civil society, and social exclusion - in particular unemployment.

Clément Desbos is Research Associate at the Centre for European Studies at the University of Limerick in Ireland. His research focuses on the movement for global justice and its relation with left-wing parties. He has also written about marginal groups in France and in Ireland.

Pascale Dufour is Professor of Political Science at the University of Montreal and Director of the Research Center on Politics and Social Development (CPDS). She works on social movements and collective action in comparative perspective.

Hanspeter Kriesi is Professor of Political Science and holds the Stein Rokkan Chair of Comparative Politics at the European University Institute in Florence, Italy. His research interests include comparative politics, political sociology, political behavior, electoral behavior, political communication, political participation, and social movements.

Maria Kousis is Professor of Sociology and Director of the Center for Research \& Studies (CRS) in Humanities, Social Sciences \& Pedagogics at the University of Crete. Her areas of specialization focus on movements and contentious politics, social change, environmental politics, bioethics and society, and Southern Europe.

Arnaud Lacheret holds a PhD from Sciences Po Grenoble and is Lecturer at IDRAC Lyon. His main areas of research are public policy, local governments, and French politics. 
Héloïse Nez is Assistant Professor of Sociology at the Université de Tours in France and researcher at the UMR CITERES (Cities, Territories, Environment, and Societies). Her main research topics are social movements, participatory democracy, and citizen competence. She is currently studying the Indignados movement and Podemos in Spain.

Leonidas Oikonomakis is a PhD researcher at the Department of Political and Social Sciences of the European University Institute in Florence, Italy. His research focuses on the different political strategies that social movements adopt in their struggle for social change (case studies: the Zapatistas of Mexico and the Cocaleros of Bolivia).

Ignacia Perugorría is a PhD candidate in sociology at Rutgers University, working on the interaction between identity battles, social movement networks, and political opportunity structures in the making of 'participatory culture'.

Jerome Roos is a PhD researcher in International Political Economy at the European University Institute in Florence, Italy. His research focuses on the structural power of the banking sector in the management of international debt crises and the implications for the quality of democracy.

George Ross is Jean-Monnet Chair ad personam at the Université de Montréal and the McGill University European Union Centre of Excellence and adjunct professor at the Department of Political Science of the Université de Montréal. His research focuses on the European Union, sociology and political economy, and the European Left.

Frédéric Royall is Senior Lecturer and Researcher at the Centre for European Studies of the University of Limerick in Ireland. His research concerns various social movements in Europe.

Michael Shalev is Professor of Sociology and Political Science at the Hebrew University of Jerusalem. He specializes in political sociology, political economy, the welfare state, and social stratification. Some of his work is based on cross-national comparisons of the advanced OECD countries.

Jackie Smith is Professor of Sociology at the University of Pittsburgh and editor of the Journal of World-Systems Research. Her research examines connections between globalization and popular movements, including 
how social movements have worked to overcome resource inequities and internal differences to build transnational alliances.

Benjamín Tejerina is Professor of Sociology and Director of the Collective Identity Research Center at the University of the Basque Country. His research interests include collective action and social movements, living conditions, precariousness and transformations in the work culture, the sociology of language and ethnolinguistic movements, collective identity, social conflict and youth transitions, and sociological theory. 



\section{Index}

"We are the $99 \% " 14,16,75,141,245,272$, 274-275, 287, 297

14J 92, 95, 98-101, 104, 106, 108, 113-117

15M 11, 13-16, 18-19, 30, 33-38, 91, 94-101, 104, 106, 109-118, 121, 126, 129-130, 138-139, 142-144, 152, 171, 177, 184-185, 200, 207-208, 227-228, 231, 234-237, 239, 259, 265, 292

Adbusters 241, 243-244, 248

Adell, Ramón 18, 31, 128

Adopter 227, 229-231, 246

Aggregation (logic of) 17, 128, 177-178, 216, 220-221, 223

Alliances 27, 116, 271-273, 276, 301-302

Almeida, Paul D. 150-151, 169

Anarchism (and anarchist) 18, 29, 31, 128, 157-158, 180, 184-188, 192, 196, 207, 211, 234, 238-240, 244-245, 269, 289, 301

Ancelovici, Marcos 14, 19, 22, 28, 32, 152, 169, 179, 297-298, 303

Anti-austerity 11, 15, 19, 32, 78-80, 93, 96, 147, 149-150, 154-155, 157-159, 162-163, 165, 168-169, 175, 205-209, 211, 216, 220, 223-225, $227,231,237-238,241-243,246-247,256-257$, $298,300,302$

Aragorn! 184, 186

Argentina 122, 148, 239, 301

Assembly (Assemblies) 13, 16, 28-29, 31, 91, 94, 121-127, 129-131, 133-142, 162, 166, 175-177, 179181, 186-189, 191-198, 207, 221-222, 233-235, 238-240, 244, 247, 266-269, 272, 301, 303

Auyero, Javier 139, 148-149, 168-169

Austerity 11, 15, 19, 23-24, 26, 32, 56-59, 67-68, 74-76, 78-80, 84100, 93, 96, 104, 125, 142, 147, $149,151,153-154,156-157,159-160,163,165-168$, $184,229,232,235,237,242-243,247,255^{-2} 57$, $285,287,295,300,303$

Bailout 23, 48, 51, 54-55, 61, 78, 81-82, 87, 95, 162, 164-166, 242

Bank guarantees 256, 269

Basque Country 19, 112, 114

Bennett, Lance 212, 214, 206-217, 224

Benski, Tova 20, 93

Béroud, Sophie 27, 289

Bush, George W. 47, 241-242

Calvo, Kerman 14, 108-110, 127

Camp 14, 30, 32, 93, 121, 124, 134, 151, 161, 165, 177, 179-180, 185, 187, 190-191, 193, 195-197, 221-222, 224, 233-234, 239-240, 242, 245, 253-254, $257-262,264-276,303$

Canada 19, 21, 26, 175, 179, 190, 299

Capitalism 20-21, 24-27, 45-46, 121, 127-128, 206, 209, 214, 218, 223, 247, 281, 295-296, 298-299
Castañeda, Ernesto 28, 30, 267

Castells, Manuel 14, 17, 19-20, 91, 141, 175, 231

Catalonia 19, 85-86, 94, 96-97, 112, 114

Celtic Tiger 253-255, 262-263, 274

Central Bank 11, 47, 51-52, 62, 147, 168, 236, 255, $257-258,263,266$

Chabanet, Didier 24, 33, 279, 283, 285, 297, 302

Challengers 69-76, 78, 87

City of London 43,47

Cleavage 32, 70, 81, 91-93, 98-100, 102-106, 108-117, 296

Clinton, Bill 44, 242

Cloward, Richard 24, 68, 283

Consensus 16, 18, 28-29, 97, 109, 128-129, 131, 140, $184,186-188,192,215,234,236,240,269,291$

Contagion $30,43,44,51,53,55$

Cox, Laurence 7, 18-19, 153

Cruells, Marta 16-17, 175

Cycle of protest 22-23, 303

della Porta, Donatella 9, 12, 18-19, 22, 24, 26, $28-30,128,149,151,153,183,213,286,296$

Democracia Real Ya! (DRY) 94, 231

Democratic Party 49, 76, 181

Direct democracy 16-17, 27, 162, 175, 180, 196, 198, 227, 239-241, 244, 247, 287

Economic and Monetary Union (EMU) 43, 44, $5^{2-56,} 5^{8}, 61-62,74$

Economic crisis 14-15, 23-24, 25-27, 31, 43, 68-69, $78-79,82,91,94,122,125,127,138-139,149$, 166, 210, 253, 264, 273, 282, 284, 295, 299-301

Economic sovereignty 257, 263

Election(s) 15-16, 28, 54, 6o-61, 67, 69, 76-8o, $82,85-86,91,94,97,109,130-131,142-143$, $157,165-166,169,182-183,242,280,282,285$, 300-301

Encampment 91104, 94-95, 101, 121-124, 127, 129-130, 133-137, 141-142, 176, 188, 221, 224, $244,253,261,263,265$

European Central Bank (ECB) 11, 47, 51-52, 147 , $168,236,255,263$

European Union (EU) 11, 49, 58, 126, 169, 232, 254

Eurozone 43, 44, 51-58, 6o-62, 79, 81-82, 147, $156-157,168$

Facebook 17, 83, 135, 157, 160-161, 165-166, 177-178, $182,233,237-238,243,257$

Facilitation (and facilitators) 177, 180, 191-194, $197,238,240$

Family of protest 12, 21, 32, 303

Federal Reserve 44, 242

Fillieule, Olivier 279, 286 
Flesher Fominaya, Christina 9, 12, 18-19, 28, 31, 129,153

Foreclosure 46, 50, 86, 121, 123, 126, 135, 138, 140, 235

Frames 17, 22-23, 26, 28, 30, 49, 153, 217, 220, 254,275

France 22, 24, 29, 33, 54, 6o-61, 70, 83, 85, 131, 179, 279-289, 291-292, 297, 302-303

Frustration 242, 253, 263-264

Gamson, William 20, 30, 72, 261, 286

General assembly (GA) 16, 28, 124, 127, 130, $133^{-135}, 137-138,141,179,187,193-194,240$, 244,303

Germany 22, 52, 54-56, 60-61, 70, 156, 187, 207, 289,299

Gitlin, Todd 13, 75-76

Global Justice Movement (GJM) 14, 17-18, 28-29, 31-32, 122, 136, 153, 177, 184, 186, 194, 208-209, $211,213,215-216,223-225,230,237,239$, $244-245,297,301,303$

Globalization 43-47, 49-50, 70, 75, 136, 150-153, 208-209, 211, 223, 281, 295

Goodwin, Jeff 24-25, 127, 296

Graeber, David 18, 27, 128, 184, 186, 192, 196, 243, 244

Great Recession 44, 48, 56, 69-70, 74, 78, 86

Greece 11, 19-20, 22-23, 28, 31-33, 52-53, 55-56, $58,60-61,68,74,78-84,86-87,91-92,131$, $147,149-152,155,158,162,164-165,167,169$, $189,227,229,232,235-239,242-243,245^{-247}$, $256-257,282-283,287,296-297,299-300,302$

Hessel, Stéphane 143, 235, 279

Hetland, Gabriel 24-25, 127, 296

Hirschman, Albert 68, 282

Horizontalism 27-28, 32, 175-177, 179-18o, 183-184, 186, 188-190, 194, 196-198, 303

Ibarra, Pedro 22, 25, 138, 175

Indignados 11, 13, 15-20, 22, 24, 30-32, 62, 83-85, 91, 94, 101, 117, 121-131, 133-143, 147, 152, 155, $157-158,159-161,163,175,177,180,184-186$, 188-189, 208, 235, 238, 244-245, 253, 257, 267, $280,287,291,295$

Inequalities 14, 17, 45, 283-284, 295, 297, 303

Internal democracy 16, 29, 124, 128-129, 142

International Monetary Fund (IMF) 11, 147, 168, $236,255,263,265$

Ireland $24,33,53,56-58,60,157,253-257,259$, 262, 264-266, 269-270, 276, 299, 302

Israel 11, 13, 19-20, 26, 30, 32-33, 83, 92-93, 96-108, 112-117, 287, 296-297, 299

Juris, Jeffrey S. 16-28, 128, 171, 178, 210-212, 215, 223, 297

Karyotis, Georgios 79-81, 296

Katz, Richard S. 69, 229
Kitschelt, Herbert 22, 28

KKE (Greek Communist Party) 79, 81-82, 157-158

Kriesi, Hanspeter 9, 22, 32, 67, 69-71, 147, 152-153, 300

Krinsky, John 19, 219, 253

Kurnik, Andrej 16-17, 19, 184

Legitimacy 25, 50, 6o, 72, 79, 92, 102, 136-137, 188, 196-197, 270, 274

Lichterman, Paul 213, 302

Mainstream media 237, 253, 261, 274, 286

Mathieu, Lilian 9, 122, 140, 285

Media 11, 15, 17, 22, 31, 72, 74-77, 91-92, 94-95, 123, $129,137,149,154,158,161,169,177-178,180$, 191, 193, 196, 212, 214, 216, 222-223, 229-230, $235,237-238,241,253-254,257-258,261,266$, $268,274,281,286,290$

Memorandum 53, 153, 155, 236, 240

Merkel, Angela 54, 81

Merklen, Denis 122, 136, 139

Milkman, Ruth 15, 19, 75, 181

National Planning Committee (NPC) 205-216, 219

Networking 28, 149, 158, 169, 177-178, 212, 215-217, 219-220, 224

Nez, Héloïse 14, 16, 28, 126, 128-129, 137, 140, 143

Nicholls, Walter 19, 148, 271, 288

North America 11-14, 72, 152, 167, 179, 181, 185, $265,267,295^{-296}$

Obama, Barack 16, 47, 75-76, 78, 242

Occupiers 17, 30, 143, 175-177, 179-183, 186, 19o, 196-197, 221-222, 245, 253-254, 257-276

Occupy Montreal 175-183, 185-186, 188-189, 192, 197-199, 303

Occupy Pittsburgh 31, 32, 221, 222

Occupy Wall Street (OWS) 11, 15-16, 19, 22, 30, 50, $91,93,141,175,179,181-182,184,186-188,192$, 197, 206, 208-209, 212, 218-220, 222-224, 228, 241, 243-246, 253, 265-269, 271, 287, 291

Oikonomakis, Leonidas 20, 30, 32, 301, 303

Okupa 18, 128, 140, 234

Organizationally brokered networks 217-218, 224

Papandreou, George 55, 78-79

Parliament 78-80, 98, 141, 143, 149, 153-156, $159-163,168,190,236,239$

Party system 69-70, 73-75, 80-82, 87, 125

PASOK (Greek Socialist Party) 61, 78-79, 81-82, 166

Pickerill, Jenny 219, 253

Piven, France Fox 24, 68, 283

Plataforma de Afectados por la Hipoteca (PAH) 141, 235

Pleyers, Geoffrey 20, 22, 29, 122, 136, 140, 142, 175,210 
Podemos 15, 23, 28, 86, 143, 300-301

Polarization 8, 82, 102-105, 116-117

Police (and policing) 11, 19, 92, 94-95, 130, 133, $137,142,148,156,159,164,168,179-180,186$, 191, 221, 233, 236, 243, 258, 266, 273, 28o, 286, 291

Political opportunities 19, 93, 282, 302

Political party (or parties) 15, 27-28, 60, 67, 73, $79,95,98,100,106,124-125,130,143,155$, 157-158, 161, 166, 169, 181-182, 190, 227, 231, $233,238,242,271,282,285,302-303$

Polletta, Francesca 29, 128

Populism (and populist) 49, 70-71, 74-75, 82, 161,245

Portugal 19-20, 53, 56-57, 6o, 83, 91-92, 152, $256-257,283$

Precariousness 23, 94, 122, 184, 299

Preferences 28, 53, 77, 175, 190, 193, 195, 197, 199, 303

Protest camp 152, 161, 165, 180, 233, 234, 242

Protest events 91, 153, 156, 163, 165-168, 178-179, 269,279

PSOE (Spanish Socialist Workers' Party or Socialist Party) 15, 94, 97, 109, 125, 142, 301

Puerta del Sol 91, 121-124, 127, 129-131, 133-137, $139,141,177,228,233,234,236-237,245^{-246}$, 286

Radical $23,26,48,78-79,82,86-87,139,161,180$, 184-188, 207, 211, 218, 223, 234, 237, 243, 247, 261, 267, 269-271, 285

Razsa, Maple 16-17, 19, 184

Real Democracy Now 83, 94, 121, 125, 127, 240, $257,259,265,290$

Recession $24,44,48,56-57,69-70,74,77-78,86$, $95-96,246,264,272,283$

Redistribution 93, 98-99, 102, 104, 106, 112,114, 116

Relative deprivation 25 -26, 80

Repertoire(s) 18, 22, 30, 68, 72, 122, 150, 155, 163 , 184-185, 190-191, 199

Representation 69-70, 83, 126-127, 189, 198, 227-229, 232, 238, 300

Representative democracy 12, 16, 21, 23, 27-28, $73,88,130,149,175,240,285,291,295$, 300-302

Republican Party (or Grand Old Party [GOP]) 49, 76-77

Republicans 48, 76-78, 87

Resonance 31-32, 72, 228-231, 235, 239, 246-247, 303

Riots 235, 237, 284

Romanos, Eduardo 14, 18, 20, 30-31, 129, 133, 141, 184-186, 245

Ross, George 52, 296

Rüdig, Wolfgang 79-81, 296

Sarkozy, Nicolas 54, 61, 81

Scales 121, 142-143, 149, 220
Segerberg, Alexandra 212, 214-217, 224

Sewell, William H. Jr. 148, 152, 159, 168-169

Sheehan, Helena 265, 268, 270-271

Skocpol, Theda 24, 76-77

Smith, Jackie 18, 152-153, 224, 270, 274, 297, 303

Social media 17, 22, 94, 149, 158, 161, 169, 178, 212, 214, 216, 222-223, 229, 237-238, 257, 266

Space 17, 21-22, 68, 70, 93, 99, 122, 129, 139, 142-143, 147-153, 159-163, 168-170, 176, 185, 188, 205, 207-210, 215-223, 230-231, 234, 244, $254,266,269,272-273,285,295,298,302-303$

Spain 11, 13-16, 18-20, 22-23, 25, 28, 30-33, 55-58, 6 o, 68, 74, 83-87, 91-116, 121-143, 152, 177, 189-190, 227-229, 231-247, 253, 257, 267, 279, 282-283, 286-287, 295-297, 300-301

Squares 11, 28, 121, 123, 129, 134, 149, 155, 157, 159, $161,163,165-166,169,177,183,185,228-229$, 235, 237-239

Syntagma Square 11, 152, 154-155, 159-163, $166-169,228,236,238-241,243,246-247$

Syriza $23,28,61,79,81-82,157,163,166,169,237$, 247,300

Tahrir Square 131, 208, 233-234, 237, 241, 243, 246

Take the Square 123, 228, 233-235, 241, 243, 245

Tarrow, Sidney 21-22, 30, 67, 72, 75, 148-149, 170, $184-185,188,229,282$

Tea Party 49, 62, 75-78, 87, 300

Tilly, Charles 24, 67, 148-151, 168-170, 184-185

Trade unions (or unions) 15, 27, 43, 62, 74-75, 78-8o, 84-85, 93-94, 98, 124-126, 157-158, 16o, $166,169,191,221,256,287,298-299,302$

Transmitter 227, 229-231, 246

Troika 11, 53, 78, 81, 147, 149, 151, 153-156, 161-167, $236-237,255^{-25} 6,287$

Twitter 17, 135, 178, 233, 257

Uitermark, Justus 19, 271, 288

Unemployment 24-25, 47-48, 50, 57-59, 77, 85, $92,94,96,126,147,232,255^{-25} 6,282-284$, $288,292,295-296$

United States (US) 13-16, 18-21, 26, 31, 33, 43-45, 47-51, 53, 61-62, 68, 74-75, 78, 83, 86-87, 93, 134, 143, 153, 179, 190, 205-206, 211, 213, 215, 217, 227-229, 241-246, 270, 287, 296-297, 299-300, 302

United States Social Forum (USSF) 205-206, 208-209, 212, 218-220, 222, 224

Varieties of capitalism 25-27, 298-299

Voss, Kim 122, 143

Wall Street 11, 43-44, 46-48, 62, 177, 228, 241-242, 244-245

Welfare regime 26, 298-299

Western Europe 70-72, 75

Williams, Michelle 122, 143

Williamson, Vanessa 76-77 
Wolfsfeld, Gadi 72, 286

World Social Forum (WSF) 152, 205-212, 214-215 217-220, 223-225
Zamponi, Lorenzo 19, 257, 279

Zapatero, José Luis Rodríguez 84-85, 232

Zapatista(s) 192, 230, 240-241, 244-245, 301

Zuccotti Park 75, 177, 243, 245-247 